\title{
Studies in the genus Hypericum L. (Guttiferae) 4(2). Section 9. Hypericum sensu lato (part 2): subsection 1. Hypericum series 1. Hypericum
}

\author{
NORMAN K.B. ROBSON
}

Department of Botany, The Natural History Museum, Cromwell Road, London SW7 5BD

THE NATURAL MTSTORY MUSEUM

\section{CONTENTS}

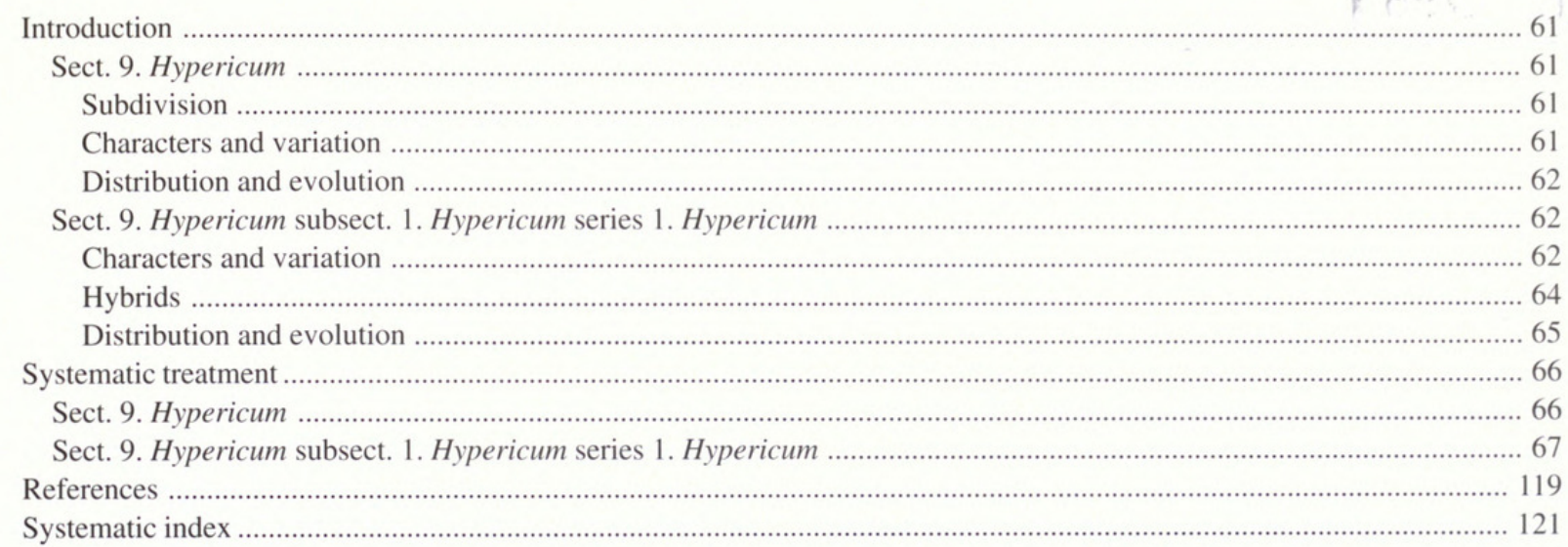

\begin{abstract}
SYNOPSIS. The subdivision of the large sect. 9. Hypericum and four of its segregated sections having been treated in Part 4(1), Part 4(2) is concerned with those members of sect. 9, viz. Hypericum sensu stricto, in which the stem internodes have glandiferous raised lines - subsect. Hypericum series Hypericum. The series comprises 11 species and can be divided into (i) a group centred in Europe and the Mediterranean (4 species) and (ii) one centred in north-east Asia (6 species), one species of which is confined to western North America and another has spread westward into Europe. The remaining species $(H$. perforatum $)$ is morphologically and geographically intermediate between two taxa, one from each group, and behaves as an allotetraploid hybrid. It is divided into four subspecies: subspp. perforatum, songaricum (Ledeb. ex Rchb.) N. Robson stat. nov., veronense (Schrank) H. Lindb. and chinense N. Robson subsp. nov. The hybrids of $H$. perforatum are treated in detail and include $H . \times$ desetangsii nothosubsp. balcanicum N. Robson, nothosubsp. nov. (H. maculatum subsp. immaculatum $\times$ perforatum). Other new hybrids proposed are: $H . \times$ laschii nothoforma froelichii N. Robson, nothoforma nov. (H. maculatum subsp. obtusiusculum $\times$ tetrapterum), $H$. undulatum $\times$ tetrapterum and $H$. elegans $\times$ perforatum.
\end{abstract}

\section{INTRODUCTION}

In Part 4(1) the relationships of sect. 9. Hypericum sensu lato were discussed and it was shown that, although the whole group is apparently derived from sect. 7. Roscyna, it consists of six independently derived sections, one from each of the three subspecies of $H$. ascyron and three from H. przewalskii (Robson, 2001: fig. 2). The latter three and sect. 9a. Concinna (related to H. ascyron subsp. gebleri) were treated in Part 4(1), this part is concerned with most of sect. 9. Hypericum (related to H. ascyron subsp. ascyron), and Part 4(3) will contain the remainder of Sect. 9 and the American sect. 9b. Graveolentia (related to H. ascyron subsp. pyramidatum).

\section{Sect. 9. Hypericum}

\section{Subdivision}

Sect. 9. Hypericum, which is distributed from the Azores through Europe, the Mediterranean and western and northern Asia to China, Japan and western North America, comprises two subsections: subsect. 1. Hypericum and subsect. 2. Erecta. The latter is almost confined to Japan, Taiwan and eastern China, whereas subsect. Hypericum is widespread. In subsect. Hypericum the stems are almost always lined and the base is stoloniferous, whereas in subsect. Erecta the stems are terete and the base is woody or fibrous. Subsect. Hypericum, in turn, can be divided into two series: series 1 . Hypericum (with stem lines persistent and bearing dark glands) and series 2. Senanensia (with stem lines weak and eglandular or absent). Series 1 is widespread, series 2 confined to northern and central Japan.

\section{Characters and variation}

The two subsections of sect. Hypericum each have primitive characters that clearly relate them individually to $H$. ascyron subsect. ascyron, but neither can be derived from the other. Thus the primitive species of subsect. Hypericum (H. maculatum), along with the closely related $H$. undulatum and $H$. tetrapterum, has markedly 4lined stem internodes, like H. ascyron; but the group as a whole is advanced in that the stem lines are glandiferous and the stems have creeping bases (i.e. they are stoloniferous). In contrast, the primitive 


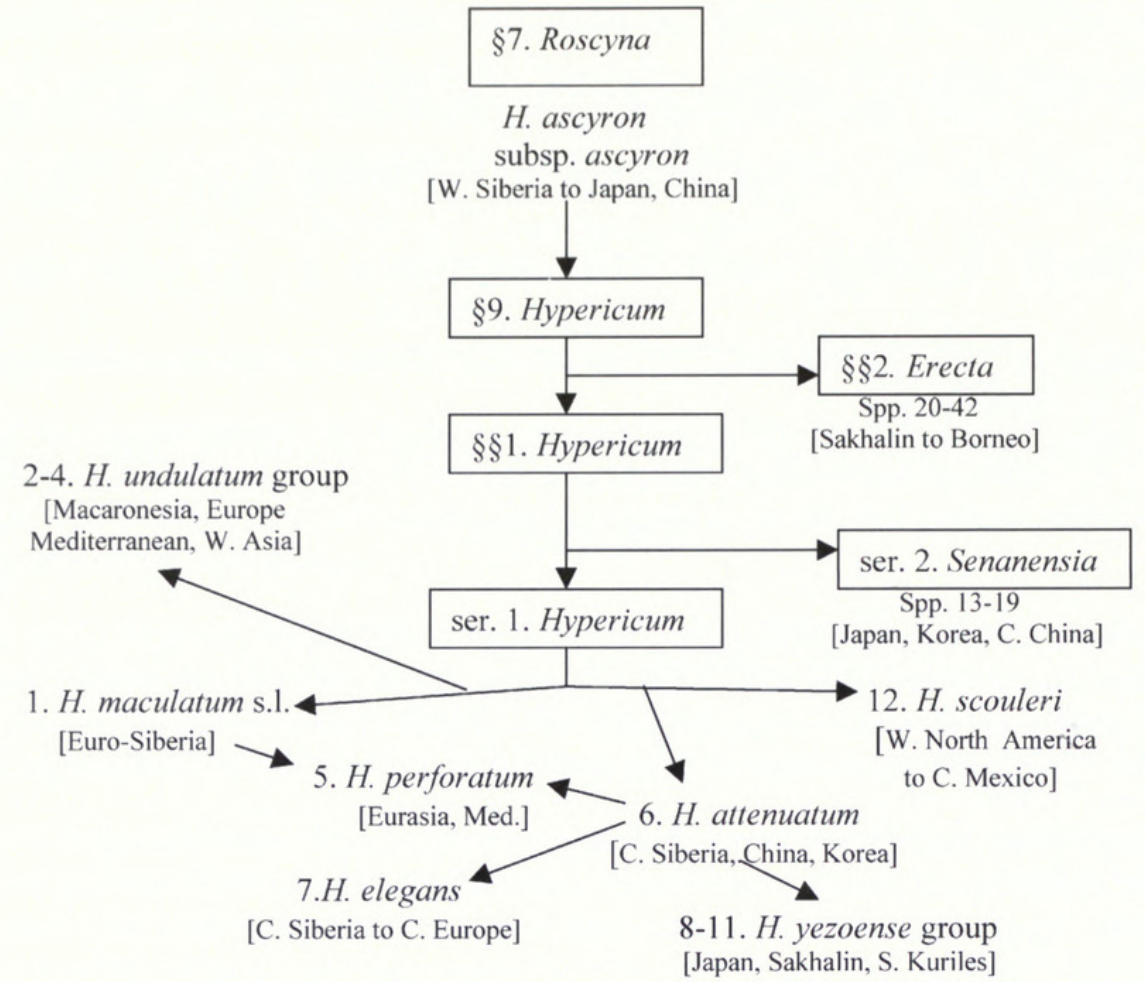

Fig. 1 Section 9. Relationships and distribution.

taxa of subsect. Erecta (H. yamamotoi var. riparium Y. Kimura and $H$. ovalifolium Koidz.) have a branching woody stem base, like $H$. ascyron, but the stem internodes are slightly 2-lined or terete, the lines being eglandular. Also, the leaves in the $H$. yamamoto $i$ and $H$. erectum groups of subsect. Erecta are frequently triangular-lanceolate, like those of $H$. ascyron subsp. ascyron, whereas a comparable form of leaf occurs only apomorphically in subsect. Hypericum, i.e. only in some of the more advanced species.

\section{Distribution and evolution}

(Fig. 1)

The distributions of subsect. 1 series 2 and subsect. 2 are wholly north and east Asian, but that of subsect. 1 series 1 extends from the Azores to Mexico. The latter series comprises a western group, based in south-eastern Europe on 1. H. maculatum and extending west to the Azores and east to central Siberia, and an eastern group with two centres, one in eastern Siberia and the other in western North America. The North American centre consists only of 12. H. scouleri, which has its most primitive form in the south-eastern United States and shows trends northward to central British Columbia and southward to Michoacán in central Mexico. The basic species of the east Asian centre is 6. H. attenuatum, which has its most primitive form in eastern Siberia and a range that extends westward to the Altai region and southward to south-central China. The basic species of the derivative Japanese $H$. yezoense group $(H$. tosaense) is morphologically very near $H$. attenuatum and has been included in it (Kitamura \& Murati, 1962), but in my opinion it is specifically distinct. Hypericum elegans, a western derivative of $H$. attenuatum, extends the distribution of the eastern group as far as western Germany.

The remaining species in series $1,5 . H$. perforatum, does not fit easily into the above scheme. Morphologically it is intermediate between 1. H. maculatum and 6. H. attenuatum, and the areas of these species almost overlap in western Siberia (Maps 1, 16). Each of them is diploid $(2 \mathrm{n}=16)$, whereas $H$. perforatum is tetraploid $(2 \mathrm{n}=32)$; so it is conceivable that $H$. perforatum is an allotetraploid derivative of a cross between them, especially as $H$. perforatum behaves cytologically as a hybrid (see p. 64). However, the nearest subspecies of $H$. maculatum to $H$. perforatum morphologically is not the one that occurs in Siberia today (subsp. maculatum) but subsp. immaculatum, which is now confined to the Balkan region. The hypothesis must therefore be that subsp. immaculatum at some time was present in Siberia, where it hybridized with H. attenuatum. The chromosomes of the resultant diploid hybrid then doubled, giving rise to an allotetraploid species that is partially fertile (see p. 88). Subsequently the area of $H$. maculatum subsp. immaculatum became greatly reduced; but that of subsp. maculatum, which is apomorphic to it and thus a likely derivative of it, extended eastward into Siberia.

\section{Sect. 9. Hypericum subsect. 1. Hypericum series 1. Hypericum}

\section{Characters and variation}

(Figs 2, 3)

MORPHOLOGY. The two main divisions of series Hypericum could be separated on whether or not the subsidiary stem lines were present, i.e. whether the stem internodes were 4- or 2-lined, were it not for (a) 4. H. triquetrifolium, which has 'lost' them in the 4-lined group and (b) 5. H. perforatum, which, as has been explained, appears to be a hybrid with one parent from each group. Figure 3 shows that the 4-lined state is primitive in this series, as indeed it is in the whole genus. Intermediate states occur in hybrids of $H$. perforatum, but not in the species.

The laminar leaf glands are absent or more rarely sparse in 1. $H$. maculatum but more or less dense in the more advanced species. They are all or mostly pale except in 6 . H. attenuatum, in which black glands often predominate.

The sepals are broad with a rounded apex in 1. H. maculatum and usually in 12. H. scouleri, as they are in the ancestral (?) H. ascyron subsp. ascyron (sect. 7. Roscyna). In all the other species they are acute and narrow (Spp. 2, 3 and 5) or acute and broad (6. H. 
3a. H. tetrapterum var. anagallidifolium
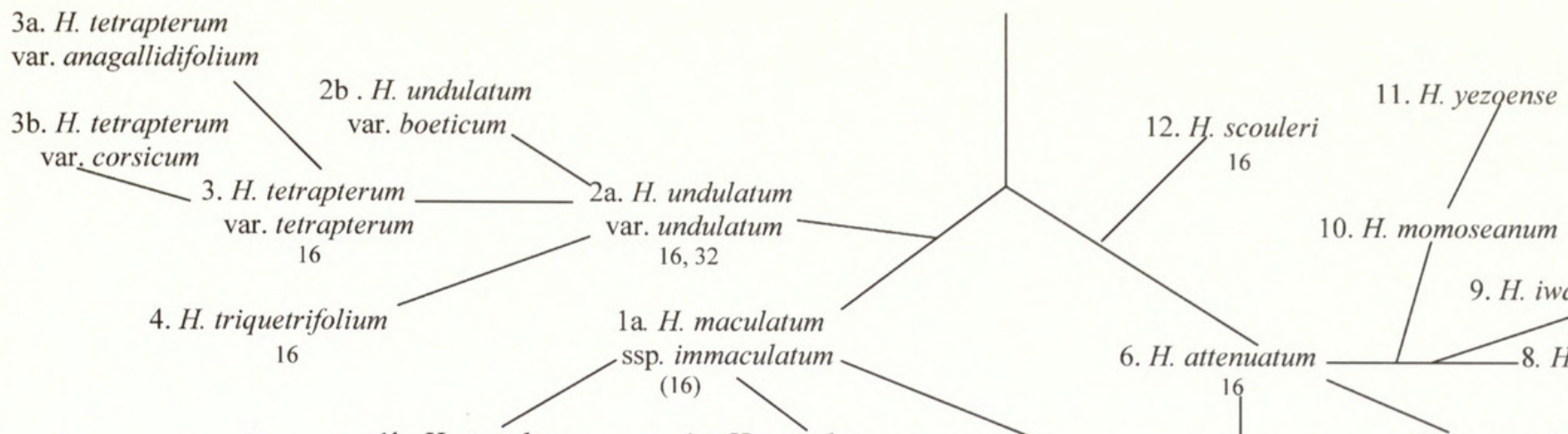

a. H. maculatum

16

ssp. immaculatum

(16)

1b. H. maculatum ssp. maculatum

1c. H. maculatum

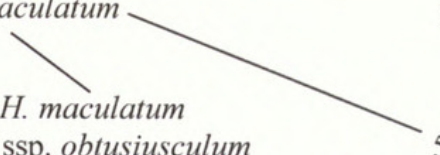

6. H. attenuatum

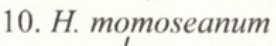
16

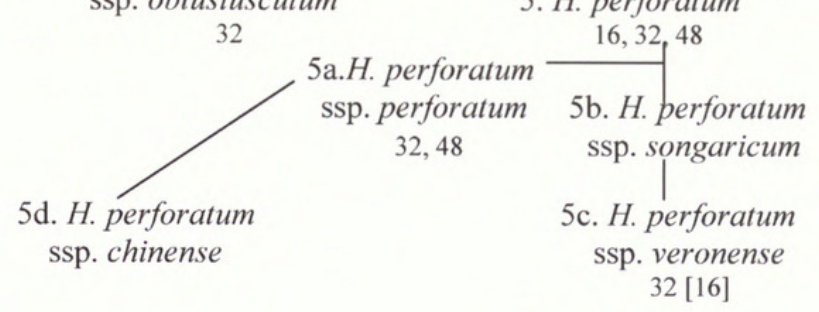

9. H. iwatelittorale

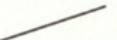
8. H. tosaense

Fig. 2 Section 9, subsect. 1, series 1. Relationships and 2n chromosome numbers.

attenuatum) or acuminate and broad (Japanese spp.) except 4. H. triquetrifolium, in which the more reduced forms have (secondarily) small rounded sepals. The apex is entire except in 2c. H. maculatum subsp. obtusiusculum and $H$. $\times$ desetangsii $(2$. H. maculatum $\times 5$. H. perforatum), where it is usually eroded-denticulate.

The petal laminar glands are primitively pale and linear to striiform (1a. H. maculatum subsp. immaculatum, 12. H. scouleri), as in sect. 7. Roscyna, and evolve in two directions: (a) the lines become interrupted, first toward the apex (Spp. 1b, 5, 6, 8-10, 12) and then throughout the lamina (Spp. 2-4, 7, 11) and sometimes disappear altogether (Spp. 2, 3); (b) some pale glands become black, but these usually remain in the minority except in $6 . H$. attenuatum and usually 1 b. H. maculatum subsp. maculatum, where all glands become black.

The vittae of the ovary and capsule are primitively all narrow and longitudinal, as in sect. 7. Roscyna; but the lateral vittae become oblique, in 4. H. triquetrifolium only sporadically, in others totally (Spp. 6-11). In 5. H. perforatum alone the oblique lateral vittae first become enlarged and then break up to form oval to globose vesicles.
CYTOlogy. Although the diploid chromosome number in sect. 7. Roscyna is usually 18, it ranges from 22 to 16 (Robson, 2001); and $2 \mathrm{n}=16$ appears to be the basic number for the whole of sect. 9 . Hypericum. In series 1. Hypericum (Fig. 2), Spp. 1b, 2-4, 6 and 12 are diploid, Sp. 1a has been shown by indirect evidence from morphology and hybrids to be diploid, and the Japanese species (811) seem likely to be so. Tetraploidy $(2 n=32)$ has been recorded in 2 . $H$. undulatum but without reference to morphology, in 1c. $H$. maculatum subsp. obtusiusculum, which appears to be an autotetraploid of 1a. subsp. immaculatum, in 7. H. elegans, which is possibly a direct derivative of 6. H. attenuatum, and in 5. $H$. perforatum, which is apparently an allotetraploid from the cross 1a. $H$. maculatum subsp. immaculatum $\times 6$. H. attenuatum. Hexaploids $(2 \mathrm{n}=48)$ have also been recorded in $H$. perforatum, presumably resulting from the fertilization of an unreduced (apomictic) ovule by a normally reduced pollen grain (see p. 88 ). The diploids reported in this species must be dihaploids resulting from polyhaploidy, i.e. the secondary occurrence of the diploid number as a result of the development of an unfertilized reduced ovule, which is known to

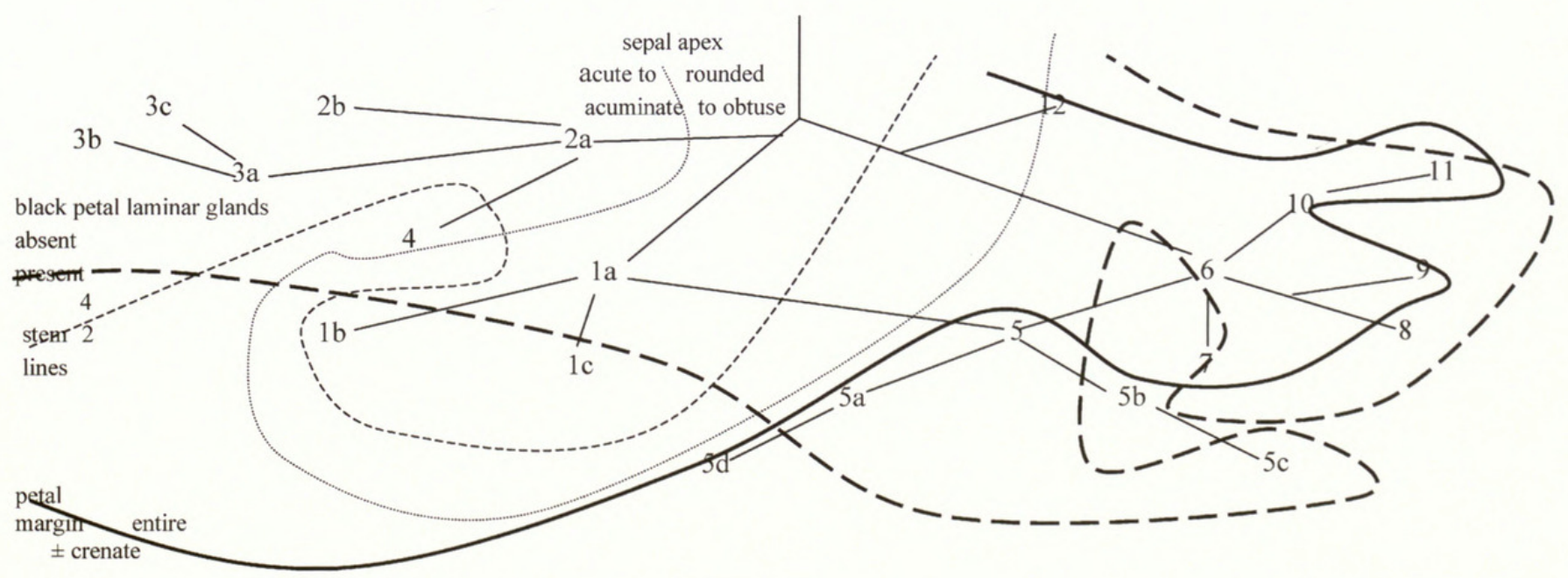

Fig. 3 Section 9, subsect. 1, series 1. Limits of some characters. 


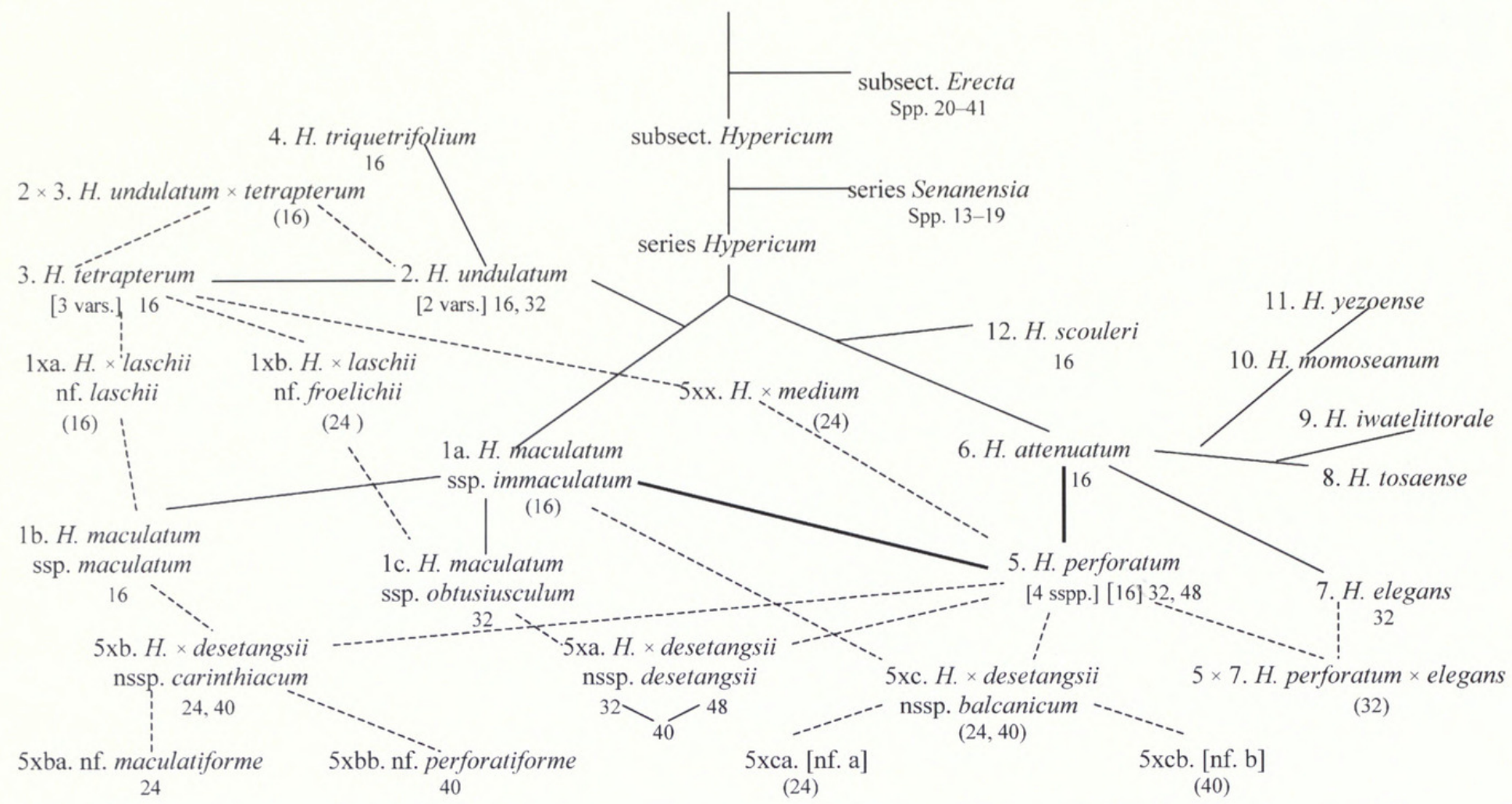

Fig. 4 Section 9, subsect. 1, series 1. Relationships (- ) and hybrids (- - -), with 2n chromosome numbers (unverified numbers in parenthesis).

occur in allopolyploids (see p. 88 and Robson, 1998). The report of a triploid number $(n=12)$ by Gagnieu \& Wilhelm (1965) is likely to be an error for $n=16$. A hypoploid number $(2 n=8, n=4)$ has been reported for 2. H. undulatum (Guillén et al., 1997), a species which is normally diploid $(2 n=16)$ or tetraploid $(2 n=32)$.

\section{Hybrids}

Natural hybridization is relatively rare in Hypericum (Robson, 1981: 167, fig. 55) except in series 1. Hypericum, where it is quite common largely on account of the floral biology of $H$. perforatum (see p. 88). This species behaves as a hybrid (high pollen sterility, lagging chromosomes at metaphase, $97 \%$ apomictic ovule development with pseudogamy). When crossed with diploids, its reduced pollen grains and ovules $(n=16)$ produce triploid $(2 n=24)$ hybrids, while the fertilization of its unreduced ovules by a gamete of a diploid species produces pentaploid $(2 \mathrm{n}=40)$ hybrids. With tetraploids such as H. maculatum subsp. obtusiusculum, of course, the hybrids are tetraploid $(2 n=32)$. Figure 4 (modified and expanded from Robson, 1981: fig. 55) shows all the hybrids that have been reported or inferred from series 1. Hypericum. The status of some of the hybrids has been inferred from intermediate morphology, while several chromosome numbers have been inferred from those of the parents.

Of the hybrids not involving $H$. perforatum, 2. H. undulatum $\times 4$. $H$. tetrapterum, which is known only from plants with intermediate morphology, appears to be rare. As the tetraploid form of $H$. undulatum has been reported only once, the hybrid is likely to be diploid. 1. H. maculatum $\times$ 4. H. tetrapterum $(H . \times$ laschii $)$ was described as intermediate between 1a. subsp. maculatum and tetrapterum and is known from the area of that subspecies only. It too is therefore likely to be diploid. On the other hand, the cross with (the tetraploid) 1c. subsp. obtusiusculum, described by Fröhlich (1911) and named here $H$. $\times$ laschii nothoforma froelichii, should prove to be triploid.

The hybrids involving $H$. perforatum can be triploid to hexaploid, depending on the ploidy of the other parent and of the gametes of $H$. perforatum itself. Aneuploid numbers occur in experimental crosses (e.g. those of Lihová et al., 2000), but they have not been reported from wild populations. Noack (1939) found that, in hybrids involving diploids, the triploids were intermediate between the parents whereas the pentaploids could not be distinguished from pure $H$. perforatum. Mártonfi et al. (1996b), however, found that a pentaploid population of $H$. maculatum subsp. maculatum $\times$ perforatum from Slovakia did have some intermediate characters as well as the pentaploid number $(2 \mathrm{n}=40)$.

Tetraploid crosses with $H$. perforatum yield intermediates, at least in the first generation. Thus a possible hybrid, 5. H. perforatum $\times 7$. H. elegans, is recorded here on the basis of a morphologically intermediate specimen from the Ukraine; and the cross H. maculatum subsp. obtusiusculum $\times$ perforatum also yields intermediate progeny in the $\mathrm{F}_{1}$. The relationship of the parents of this latter cross is very close, however, as subsp. obtusiusculum behaves cytologically and morphologically as an autotetraploid of subsp. immaculatum, not of subsp. maculatum, as I first thought (Robson, 1956; 1958a, 1975). This consanguinity facilitates back-crossing and results in the eventual occurrence of a complete series of intermediates in the wild (cf. Crackles, 1990). Counts of $2 n=48$ and 40 for this hybrid from cultivated plants (Robson, 1956; Robson \& Adams, 1968) presumably result respectively from a cross with an unreduced perforatum gamete $(32+16)$ and a backcross of this hybrid to either a 'normal' hybrid or to $H$. perforatum itself $(24+16)$.

The species 3. H. tetrapterum is diploid only, so its cross with $H$. perforatum $(H . \times$ medium $)$, described as morphologically intermediate, is likely to be triploid; but the cross 1 . H. maculatum $\times 5$. perforatum $(H . \times$ desetangsii $)$ is much more complicated. The hybrid with the tetraploid 1c. maculatum subsp. obtusiusculum (5xa. H. $\times$ desetangsii nothosubsp. desetangsii) is also usually tetraploid and has been considered above. That with the diploid 1a. maculatum subsp. immaculatum $(5 \mathrm{xc} . \mathrm{H} . \times$ desetangsii nothosubsp. balcanicum) and 1b. maculatum subsp. maculatum $(5 \mathrm{xb} . H . \times$ 
desetangsii nothosubsp. carinthiacum) occurs in two forms depending on the sex of the gametes. With H. maculatum pollen, triploids $(2 \mathrm{n}=24)$ are produced (e.g. $5 x$ ba nothoforma maculatiforme $)$ whereas with perforatum pollen, the progeny are pentaploid $(2 \mathrm{n}=40)(\mathrm{e} . \mathrm{g}$. $5 \mathrm{xbb}$ nothoforma perforatiforme). The corresponding hybrids with 1a. H. maculatum subsp. immaculatum have not yet been recognized or named.

\section{Distribution and evolution}

(Fig. 5)

As has already been explained (p. 61), sect. Hypericum is most closely related to $H$. ascyron subsp. ascyron (Sect. 7. Roscyna), and subsect. Hypericum is distributed over most of the Paleotemperate Region from the Azores to Mexico. The distribution of series Hypericum occupies most of this area except south-eastern China and south Japan. It is divided into two groups (i) mainly western and (ii) mainly eastern.

Group (i), which extends from the Azores to central Siberia, includes the nearest taxon morphologically to series 2, 1a. $H$. maculatum subsp. immaculatum, which is restricted to the central Balkan region but differs little from the north Japanese $H$. kamtschaticum var. pibairense Miyabe \& Y. Kimura (series 2), mainly in having constantly 4-lined gland-bearing stem internodes. Subsp. immaculatum appears to have given rise northward (group iii) to two subspecies: (a) by vicariance to $1 \mathrm{~b}$. subsp. maculatum (Atlantic coast to central Siberia) and (b) by autotetraploidy to 1c. subsp. obtusiusculum ( $=H$. dubium Leers) (north-west Europe). Southward there is a derivative (group iv) that divided into a western (damp habitat) subgroup (Spp. 2-3) and an eastern (dry habitat) one (Sp. 4). In group (iii) the stems are 4-lined, the leaves broad and plane and the sepals broad and rounded (entire or not); in group (iv) the stem lines become broad (3. H. tetrapterum) or the subsidiary pair disappear altogether (4. H. triquetrifolium), the leaves become undulate (2a. H. undulatum var. undulatum) and narrow (4. $H$. triquetrifolium) or remain broad but revert to plane (2b. H. undulatum var. boeticum, 3. H. tetrapterum), whilst the sepals become narrow and acute but, in $H$. triquetrifolium, revert to rounded when small.
Although a Portuguese specimen of $H$. undulatum was observed to have a habit and narrow leaves that approach those of $H$. triquetrifolium, these characters would seem best interpreted as a parallel development within $H$. undulatum. The first division in group (iv) would then have been between the western Mediterrean/ Atlantic wet-habitat $H$. undulatum and the east Mediterranean/W. Asian dry habitat $H$. triquetrifolium. The species 3. H. tetrapterum, with broad stem lines, broader plane leaves and a more congested inflorescence of smaller flowers subsequently evolved (in the southwestern Mediterranean?) from $H$. undulatum and spread north as far as Scotland, Denmark and southern Sweden, north-east to Poland, Latvia and the western Ukraine, and east to Iran.

Group (ii) divides immediately into an eastern, Old World subgroup (v) and a western, West American subgroup (vi), both of which start with a single species, respectively the eastern Siberian and Chinese 6. H. attenuatum and the British Columbia to Mexican 12. H. scouleri. Whilst none of the variation in $H$. scouleri has resulted in speciation, $H$. attenuatum has speciated eastward and westward. To the west it gave rise to 7. H. elegans, which inhabits steppe regions as far into Europe as south Germany (Saxony, with isolated stations further west). Eastward there is a group of species in Japan of which the two southern, 8. H. tosaense (Shikoku) and 9. $H$. momoseanum (C. Honshu) have at one time been included in $H$. attenuatum. They both occur in isolated localities, as does a close relative of $H$. tosaense, 9. $H$. iwatelittorale, in northern Honshu. On the other hand, the northern relative of $H$. momoseanum, 11. $H$. yezoense, is widely spread in Hokkaido and northern Honshu and also occurs in southern Sakhalin.

As we have seen, 5. H. perforatum has apparently resulted from a cross between one taxon from group (iii) (1a. H. maculatum subsp. immaculatum) and one from group (v) (6. H. attenuatum). It was suggested that the cross occurred in western Siberia, and the present distribution and variation of $H$. perforatum supports this suggestion. Both parents have sessile herbaceous leaves, and the first division (vii) is between 5a. subsp. perforatum, with shortly petiolate herbaceous concolorous leaves and 5b. subsp. songaricum, with sessile, often subcoriaceous and discolorous leaves. Subsp. perforatum has

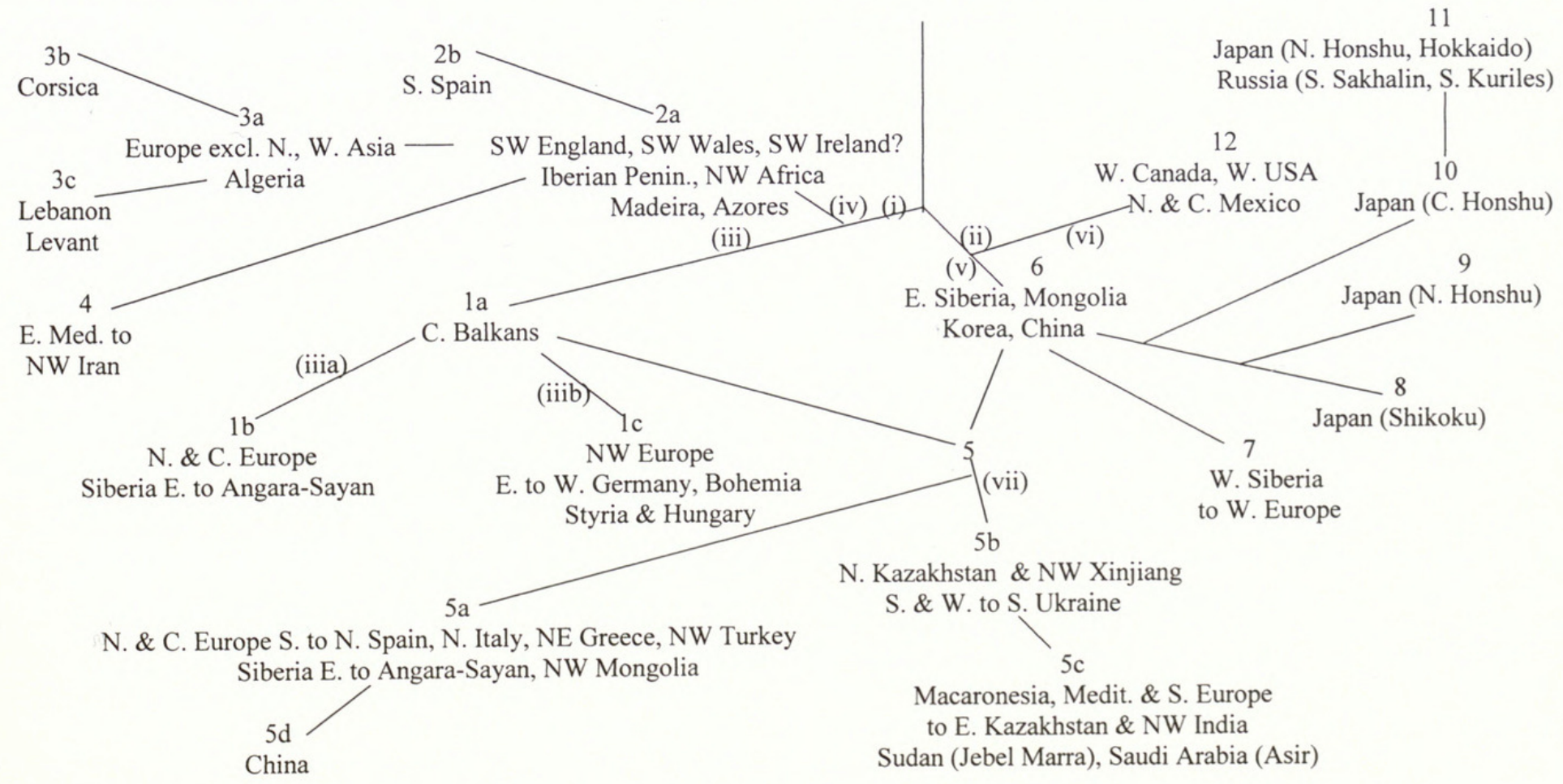

Fig. 5 Section 9, subsect. 1, series 1. Distribution. 
spread westward throughout northern and north-western Europe and eastward into central Siberia. Beyond Siberia it recurs, morphologically scarcely altered, in China to the south-east of the Mongolian desert and steppe region and is transformed gradually south-eastward into a narrow-leaved form with long branches and congested inflorescences (subsp. chinense). Subsp. songaricum is present in the mountains of north-eastern Kazakhstan and adjacent Kyrghizstan and Xinjiang (China); then, after a gap of over $2500 \mathrm{~km}$, it recurs in southern Russia (Astrakhan, Ciscaucasus) and Krym. There, with a small transitional zone, it is replaced by $5 \mathrm{c}$. subsp. veronense, which appears to have spread through Turkey westward into southern Europe, the Mediterranean and Macaronesia, south to Saudi Arabia and the Sudan Republic (Jebel Marra - if truly native there, see Wickens, 1976a, 1976b: 98), and east to the western Himalaya and Central Asia.

Distributions of species and species groups in series Hypericum show few wide disjunctions, but those that do occur are remarkable. The widest is in group (ii), where the eastern Siberian centre of variation (i.e. primitive form) of $H$. attenuatum is now separated from that of $\mathrm{H}$. scouleri in Arizona and New Mexico by the north Pacific Ocean. This distribution would seem to support the inference by Hui-lin Li (1952) that plants with eastern Asia - western North America disjunctions are predominantly herbaceous; and it is thus also likely to support his other inference, that such disjunctions are more recent than those involving eastern North America. Hypericum scouleri is a member of the Arcto-Tertiary element of the Californian flora (Axelrod, 1959; Raven \& Axelrod, 1978), where it occurs in the Yellow Pine (Pinus ponderosa Dougl. ex P. \& C. Lawson) forests of the Sierra Nevada (Munz \& Keck, 1959). It is possible, therefore, that $H$. scouleri has been in western North America since the Miocene.

The other notable disjunction has already been mentioned. It would appear that $H$. maculatum subsp. immaculatum, now confined to the central Balkans, once had a distribution extending into western (or even central) Siberia, where it crossed with $H$. attenuatum and gave rise to $H$. perforatum. Its close resemblance to $H$. kamtschaticum var. pibairense, of northern Japan, implies that subsp. immaculatum (or its immediate ancestor) migrated south-westward (without differentiating?) and eastward with minimal differentiation. It has so far not been possible to estimate the geological age of these disjunctions.

\section{SYSTEMATIC TREATMENT ${ }^{1}$}

\section{Sect. 9. HYPERICUM}

Perennial herbs or very rarely suffrutices up to $1.2 \mathrm{~m}$ tall, with stems erect to prostrate, glabrous, without or with dark (black or very rarely reddish) glands; branching lateral, from upper or most nodes. Stems 4-2-lined or -winged when young, remaining so or becoming terete, eglandular or with glands confined to the lines or not. Leaves opposite or abnormally 3-whorled, decussate, sessile to shortly pseudopetiolate, free, persistent; lamina entire with venation pinnate, closed, with tertiary reticulation dense to lax and obscure; laminar glands punctiform or rarely shortly striiform, equal or unequal; intramarginal glands black or occasionally also pale; ventral glands absent. Inflorescence 1-c. 70-flowered with branching dichasial-monochasial from 1-4 nodes, often with subsidiary branches from lower nodes; bracts and bracteoles foliar or reduced, persistent. Flowers stellate, homostylous. Sepals 5, free or united at base, persistent, erect to recurved in fruit, with margin entire or denticulate to glandular-ciliate; veins $3-5(-7)$; laminar glands pale and/or dark, linear to punctiform; marginal and/or intramarginal glands dark and/or very rarely pale or rarely absent. Petals 5, persistent, erect but not twisting after flowering, without apiculus; margin entire to crenate or eroded-denticulate to ciliate; laminar glands linear to punctiform, pale and/or dark; marginal glands dark, immersed to \pm prominent, or absent. Stamen fascicles ' 3 ' (i.e. united $2+2+1$ ), persistent, with stamens totalling 20-c. 100; filaments basally united; anther gland dark or rarely amber; pollen types IV?, X. Ovary with 3(4) completely or almost completely axile placentae, each $\infty$-ovulate; styles 3(4), divergent from discrete bases; stigma narrowly capitate or narrow. Capsule 3(4)-valved, chartaceous, with valves longitudinally vittate or sometimes \pm laterally vittate to vesiculate, pale. Seeds cylindric, not carinate or appendiculate; testa scalariform-reticulate to finely foveolate.

BASIC CHROMOSOME NUMBER (X). 8; ploidy 2, 4 (rarely 3, 5, 6).

HABITAT. Various; 0-3150 m.

Distribution. Macaronesia, Europe (except extreme north), north-west Africa, south-west Asia (mesophytic regions) east to north-west India (Uttar Pradesh), central Asia, southern Siberia, north-west Mongolia, Korea, China (except the south-east, Tibet, Qinghai and E. Xinjiang), Japan, western Canada, western U.S.A., north-west to central Mexico. Represented in many other parts of the world by $H$. perforatum as an introduction.

42 species in 2 subsections, one with 2 series (for infraspecific taxa and hybrids, see subsectional descriptions).

\section{Key to subsections and series of sect. 9. Hypericum}

Rootstock herbaceous, stoloniferous; stems persistently 2-4-lined or -winged, with glands on the lines and occasionally elsewhere or eventually terete and eglandular; black laminar leaf glands few or none (sometimes numerous in Sp. 6); capsule valves sometimes with lateral oblique vesicles (subsect. 1. Hypericum) ................ 2

Rootstock woody or fibrous, not stoloniferous; stems always eventually terete, eglandular (sometimes except Sp. 39); black laminar leaf glands usually present; capsule valves always longitudinally vittate ...... subsect. 2. Erecta

2 Stems persistently 2-4-lined, lines glandiferous, at least one pair prominent (sometimes weak and eglandular in Sp. 12). series 1. Hypericum

Stems eventually terete (except Sp. 13), eglandular, lines weak ... series 2. Senanensia

Subsect. 1. Hypericum. Type: H. perforatum L.

Stem internodes persistently 2-4-lined or narrowly 4-winged, the lines and sometimes elsewhere black- or rarely reddish-glanddotted (very rarely terete and often eglandular in 12 . H. scouleri). Leaves with laminar glands all pale or a few (sometimes more in 6. H. attenuatum) black, punctiform, or absent. Bracts and bracteoles entire. Petals with laminar glands pale to black, linear to punctiform, or absent; marginal glands immersed or sessile. Capsule valves (i) longitudinally vittate or with (ii) dorsal and lateral vittae or (iii) vesicles with or without dorsal vittae. Seeds linear-foveolate to finely foveolate. Species 1-19.

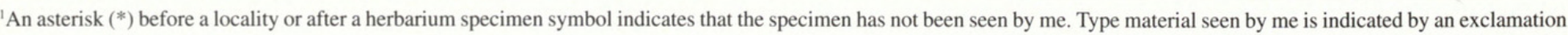
mark (!). 


\section{Series 1. Hypericum}

Hypericum sect. Euhypericum subsect. Homotaenium series Attenuata, series Kamtschatica pro parte quoad $H$. yezoënse, series Acuta, series Quadrangula, series Elegantia, series Crispa Gorschk. in Shishkin \& Bobrov, Fl. URSS 15: 236-244 (1949), nom. invalid. omnia sine descr. lat.

Hypericum sect. Euhypericum subsect. Heterotaenium series Perforata Gorschk. in Shishkin \& Bobrov, Fl. URSS 15: 247 (1949), nom. invalid. sine descr. lat.

Hypericum sect. Homotaenium series Quadrangula Y. Kimura in Nakai \& Honda, Nova Fl. Jap. 10:136 (1951). Type: H. quadrangulum L., nom. rejiciendum ( $=H$. tetrapterum $\mathrm{Fr}$.).

Hypericum sect. Homotaenium series Crispa Y. Kimura, loc. cit. (1951). Type: H. crispum L. (= H. triquetrifolium Turra).

Hypericum sect. Homotaenium series Bilineata Y. Kimura, loc. cit. (1951). Type: H. attenuatum Fisch. ex Choisy.

Stems persistently 2-4-lined, lines glandiferous, at least one pair prominent (sometimes weak and eglandular in Sp. 12). Spp. 1-12.

\section{Key to sect. 9. Hypericum subsect. 1. Hypericum series 1. Hypericum}

Stem internodes completely 4-lined or 4-winged; capsule valves longitudinally vittate (rarely interrupted to vesiculate in Sp. 4)

Stem internodes partially 4-lined or 2-lined; capsule valves longitudinally vittate to vesiculate

9

2(1) Sepals unequal, apex rounded to obtuse or subacuminate, entire to eroded-denticulate; leaves with venation \pm densely reticulate and laminar glands absent or scattered, relatively large

(1. maculatum) .. 3

Sepals subequal to equal, apex acute to acuminate, entire; leaves with venation \pm laxly reticulate; laminar glands always present, varying in size

... 5

3(2) Stem internodes always with complete subsidiary lines; inflorescence branches making narrow angle $\left(c .30^{\circ}\right)$ with stem; sepals with apex entire; petals entire, with laminar glands black and dots to short streaks or linear and pale

Stem internodes with complete or incomplete subsidiary lines; inflorescence branches making a broad angle $\left(c .50^{\circ}\right)$ with stem; sepals with apex usually finely eroded-denticulate; petals usually distally unilaterally crenate, with laminar glands black, mainly lines to streaks

1c. maculatum subsp. obtusiusculum

4(3) Sepals and petals with only pale glands; petal glands lines to streaks 1a. maculatum subsp. immaculatum

Sepals and petals with mostly black glands; petal glands dots and short streaks ......................... 1b. maculatum subsp. maculatum

5(2) Stem internodes \pm equally narrowly 4 -winged; leaf margin usually crisped-undulate; inflorescence lax; flowers $12-17 \mathrm{~mm}$ in diam.; sepals nearly always with 3-28 laminar black glands; petals bright yellow, nearly always red-tinged dorsally (2. undulatum) ........ 6

Stem internodes \pm broadly 4 -winged, the principal lines wider; leaf margin nearly always plane; whole inflorescence or partial inflorescences dense; flowers $10-15 \mathrm{~mm}$ in diam.; sepals without or rarely with 1-2 laminar glands; petals rather pale yellow, not red-tinged ( 3 . tetrapterum)

6(5) Petals tinged red dorsally; leaves elliptic to ovate, margin crispedundulate; plant erect ................... 2a. undulatum var. undulatum

Petals not tinged red; leaves broadly elliptic to orbicular, margin entire; plant erect to decumbent .... 2b. undulatum var. boeticum
Inflorescence 10-c. 70-flowered from 1-4 nodes; stems erect ....... 3a. tetrapterum var. tetrapterum

Inflorescence 1-3-flowered from terminal node; stems procumbent to ascending ......

8(7) Leaves elliptic to orbicular, mostly $0.5 \mathrm{~mm}$ petiolate, margin plane; inflorescence without flowering branches

3b. tetrapterum var. corsicum

Leaves elliptic to triangular-ovate, subsessile to $0.5 \mathrm{~mm}$ petiolate, margin undulate; inflorescence sometimes with flowering branches from up to 5 nodes below

3c. tetrapterum var. anagallidifolium

9(1) Leaf margin crisped-undulate, lamina usually triangular-lanceolate; stem widely branched for most of its length, forming broad pyramid; sepals $1-3 \mathrm{~mm}$ long 4. triquetrifolium

Leaf margin plane, lamina ovate or oblong or elliptic to linear; stem narrowly branched rarely below middle, forming at most narrow pyramid; sepals (2.5)3 mm or more long.

10(9) Stem lines (at least) with black glands, principal lines always present; petal margin usually distally black-glandular-crenate .....

11

Stem lines eglandular or very rarely with a few reddish glands, principal lines rarely absent (i.e. rarely terete); petal margin entire to distally black-glandular-subcrenate .......................... 12. scouleri

11(10) Subsidiary stem lines nearly always \pm developed; sepals often eglandular-denticulate; other characters to varying degrees intermediate between 1. H. maculatum and 5. H. perforatum (see key, p. 101) …......................................................... 5x. × desetangsii

Subsidiary stem lines absent; sepals entire; other characters not so intermediate

12(11) Capsule valves with lateral vittae or vesicles and often dorsal vittae (5. perforatum)

Capsule valves with longitudinal vittae only 16

13(12) Leaves (at least on main stem) sessile; petal laminar glands usually all pale

Leaves all petiolate; petal laminar glands pale and/or black ..... 15

14(13) Capsule valves with lateral vittae linear or slightly swollen overall, not interrupted; sepals finely acuminate; leaves oblong to oblongovate, base \pm shallowly cordate-amplexicaul

5b. perforatum subsp. songaricum

Capsule valves with lateral vittae swollen at base and/or interrupted to short and irregular (vesicular); sepals acute; leaves usually narrowly triangular-lanceolate to linear or, if broader, then short ( $c$. 5-10 mm long), base rounded to cuneate

5c. perforatum subsp. veronense

15(13) Inflorescence and/or partial inflorescences not usually congested, branches relatively short, straight; leaves usually oblong to ovate or elliptic; at least some petal laminar glands pale

5a. perforatum subsp. perforatum

Inflorescence and/or partial inflorescences congested, branches relatively long, curved-ascending; petal laminar glands all black or absent ....................................... 5d. perforatum subsp. chinense

16(12) Sepals black-glandular-ciliate or with sessile black marginal glands 7. elegans

Sepals entire or with apical black gland only, without or with immersed black marginal glands .............................................. 17

17(16) Sepals and petals with pale and black laminar glands; stem often with scattered black or reddish glands; sepals acute to subacuminate 6. attenuatum 
Sepals and petals with pale laminar glands only; stem with black glands confined to raised lines or near them; sepals acute to abruptly acuminate 18

18(17) Leaves without black laminar glands; inner petal margin crenulate (unknown in 9. iwatelittorale); stems usually erect, rather woody

Leaves usually with a few black laminar lands; inner petal margin \pm plane; stems usually \pm ascending, herbaceous ........................... 20

19(18) Leaves all sessile, mostly elliptic or oblong-elliptic to narrowly oblong; flowers $15-18 \mathrm{~mm}$ in diam.; sepals $2.5-3 \mathrm{~mm}$ long, gradually to abruptly acuminate, intramarginal glands always present, spaced 8. tosaense

Leaves on lateral branches petiolulate, elliptic to oblanceolate; flowers $9-10 \mathrm{~mm}$ in diam.; sepals $3-4 \mathrm{~mm}$ long, acute to subacuminate, intramarginal glands few or absent.....

9. iwatelittorale

20(18) Stems single, $0.25-0.65 \mathrm{~m}$, erect or basally ascending; inflorescence 7-11-flowered from $2-3$ nodes, usually with $1-4$ flowering branches below 10. momoseanum

Stems usually caespitose, $0.1-0.35 \mathrm{~m}$, erect to procumbent; inflorescence 3-7(-9)-flowered from 1-2 nodes, with 0-1 flowering branches below 11. yezoënse

1. Hypericum maculatum Crantz, Stirp. austr: 2: 64 (1763), 2nd ed. 2: 98 (1769); Allioni, Fl. pedem. 2: 45 (1785), 3: t. 83 f. 1 (1785) pro parte, excl. syn. H. androsaemifolium Vill.; Schinz \& Keller, Fl. Schweiz, 3rd ed., 1: 358(1909); A. Fröhl. in Sitzungsber. Kaiserl. Akad. Wiss., Math.-Naturwiss. Kl. 120(1): 538 (1911), in Oesterr. bot. Z. 63: 18 (1913); Thellung in Allg. Bot. Z. Syst. 18: 19 (1912); Hayek, Prodr. Fl. Pen. balc. 1: 534 (1925); Hegi, Ill. Fl. Mitt.-Eur. 5(1): 517 pro parte, excl. f. 2004 (1925); N. Robson in Bot. Soc. Brit. Isles Proc. 2: 237 (1957), in op. cit. 3: 99 (1958), in Davis, Fl. Turkey 2: 400 (1967) in adnot., in Tutin et al., Fl. Europ. 2: 268 (1968); Zelený et al. in Futák \& Bertová, Fl. Slovenska 3: 302, t. 37 f. 1 (1982); A. Ramos in Trab. Dept. Bot. Univ. Complut. Madrid 12: 49, t. 3 f. 1 (1983), in Acta Bot. Malac. 11: 167, f. 6e (1986), in Castroviejo et al., Fl. Iberica 3: 168 (1989); Hagemann in Flora 173: 112-115, tt. 12-14, 39 (1983); N. Robson \& Strid in Strid, Mtn Fl. Greece 1: 607 (1986); N. Robson in Cullen et al., Europ. Gdn Fl. 4: 60 (1995); in Wisskirchen \& Haeupler, Standardliste Farn-u. Blütenpfl. Deutschl.: 269 (1998). Type: Austria, 'alpen', 1760 (fl), Breÿn in Crantz 828 (BP!-lectotype, N. Robson, selected here).

Fig. 6, Maps 1, 2.

Perennial herb $0.2-0.6 \mathrm{~m}$ tall, erect or ascending from creeping and rooting base, with stems numerous to few, initially unbranched below inflorescence, later branched above for $c$. 2/3 of their length. Stems 4lined, the subsidiary ones (decurrent between leaves) often less prominent or even partially absent ${ }^{2}$, usually with black glands on the lines; internodes $10-50 \mathrm{~mm}$, shorter than to exceeding leaves. Leaves sessile; lamina $15-40 \times 10-20 \mathrm{~mm}$, broadly to narrowly elliptic, paler beneath, chartaceous; apex rounded, margin plane, base rounded; venation: 3(2) pairs of main laterals from lower quarter to base of midrib, tertiary reticulation dense; laminar glands absent or rarely pale, scattered, sometimes also black, few, punctiform; intramarginal glands black, \pm close, irregular in size. Inflorescence (2-)3-c. 15flowered, from 1-3 nodes, with flowering branches narrowly or curved ascending from up to 5 nodes, the whole cylindric to broadly pyramidal or subcorymbiform; pedicels $1.5-4 \mathrm{~mm}$; bracts and bracteoles up to $5 \mathrm{~mm}$ long, narrowly triangular-ovate to narrowly elliptic, entire. Flowers (15-)20-25(-35) $\mathrm{mm}$ in diam., stellate to reflexed; buds broadly ellipsoid, rounded to obtuse. Sepals $5, \pm$ unequal, $3.5-4.5(-5) \times 2-2.7(-3) \mathrm{mm}$, broadly elliptic to broadly ovate or \pm broadly oblong, rounded to obtuse or subacuminate (varying in same flower), entire to eroded-denticulate, erect to recurved in bud, recurved in fruit; veins $5(-7)$, not or slightly branched; laminar glands pale and sometimes also black, punctiform and sometimes striiform; intramarginal glands pale or occasionally black or often absent. Petals 5, golden yellow, not tinged red in bud, (8-) 10-15 × 4-7.5 mm, c. $3 \times$ sepals, broadly elliptic to obovate or more rarely symmetrically oblanceolate, distally crenate or entire; laminar glands pale and/or black, punctiform and sometimes proximally striiform to linear (in subsp. immaculatum almost all linear); intramarginal glands few, distal or usually absent. Stamens 50-80(100), '3'-fascicled, longest 7-10 mm, c. 0.65-0.9 × petals; anther gland black. Ovary 3-locular, 2-4 × 1.5-2.5 mm, \pm broadly ovoid to ovoid-ellipsoid; styles 3 , free, $3-4 \mathrm{~mm}, 1-1.5(-2) \times$ ovary, rather narrowly spreading; stigmas narrowly capitate. Capsule 6-10 $\times 4-6$ $\mathrm{mm}$, c. $2-2.5 \times$ sepals, ovoid-ellipsoid to \pm broadly ovoid; valves with longitudinal vittae, linear to striiform. Seeds dark brown, $0.8-1.2 \mathrm{~mm}$, cylindric, not carinate or appendiculate; testa finely linear-foveolate. $2 \mathrm{n}=16,32$ (see under subspecies).

In usually rather damp habitats - woods, scrub, grassland, moorland, meadows and ditches; 0 (W. Scotland) - $2650 \mathrm{~m}$ (SE Switzerland).

Europe from Scotland (Ross-shire), northern Scandinavia (to Hinnoya (Lofoten Is.), 68 $22^{\prime} \mathrm{N}$ ), northern European Russia and western Siberia, south to northern Spain, northern Italy, northern Greece and the central Ukraine, and east to south-western Siberia (R. Ob) with eastern outlier near Krasnoyarsk). Introduced into Canada (British Columbia).

Hypericum maculatum is the most primitive species in the (mainly European) series Hypericum, its nearest relative in the (eastern) series Senanensia (Spp. 13-19) being 13. H. kamtschaticum var. pibairense from Hokkaido (N. Japan). It comprises two diploid subspecies (subspp. maculatum and immaculatum) and a tetraploid subspecies (subsp. obtusiusculum) that, from chromosome morphology and synthesis by colchicine doubling of subsp. maculatum (Robson, 1958a), would appear to be autotetraploid. The latter has sometimes been treated as a species (H. dubium Leers); but (i) the autotetraploidy and (ii) the occasional difficulty in assigning a plant to one or other taxon indicate that subspecies is the most appropriate rank, pace Mártonfi et al. (1999) (see p. 75).

The diploid subspecies of $H$. maculatum comprise two populations overlapping in distribution. One (subsp. immaculatum) is confined to the south Balkans and lacks black glands on the petals, the pale ones being linear and the leaves usually pale-gland-dotted. Its chromosome number has not yet been counted, but morphologically it is very similar to subsp. maculatum, less so to subsp. obtusiusculum. The other population (subsp. maculatum), which is widespread and slightly overlaps in area that of subsp. immaculatum in a zone from Bosnia to southern Bulgaria, has petals with punctiform to shortly striiform black glands, the pale (punctiform) glands being few, and the leaves usually lack pale gland dots.

1a. Hypericum maculatum subsp. immaculatum (Murb.) A. Fröhl. in Sitzungsber. Kaiserl. Akad. Wiss., Math.-Naturwiss. Kl. 120(1): 547, f. 8 (1911), in Oesterr. Bot. Z. 63: 18 (1913), in Mitt. Naturwiss. Vereines Steiermark 51: 223 (1915); Hayek, Prodr. 


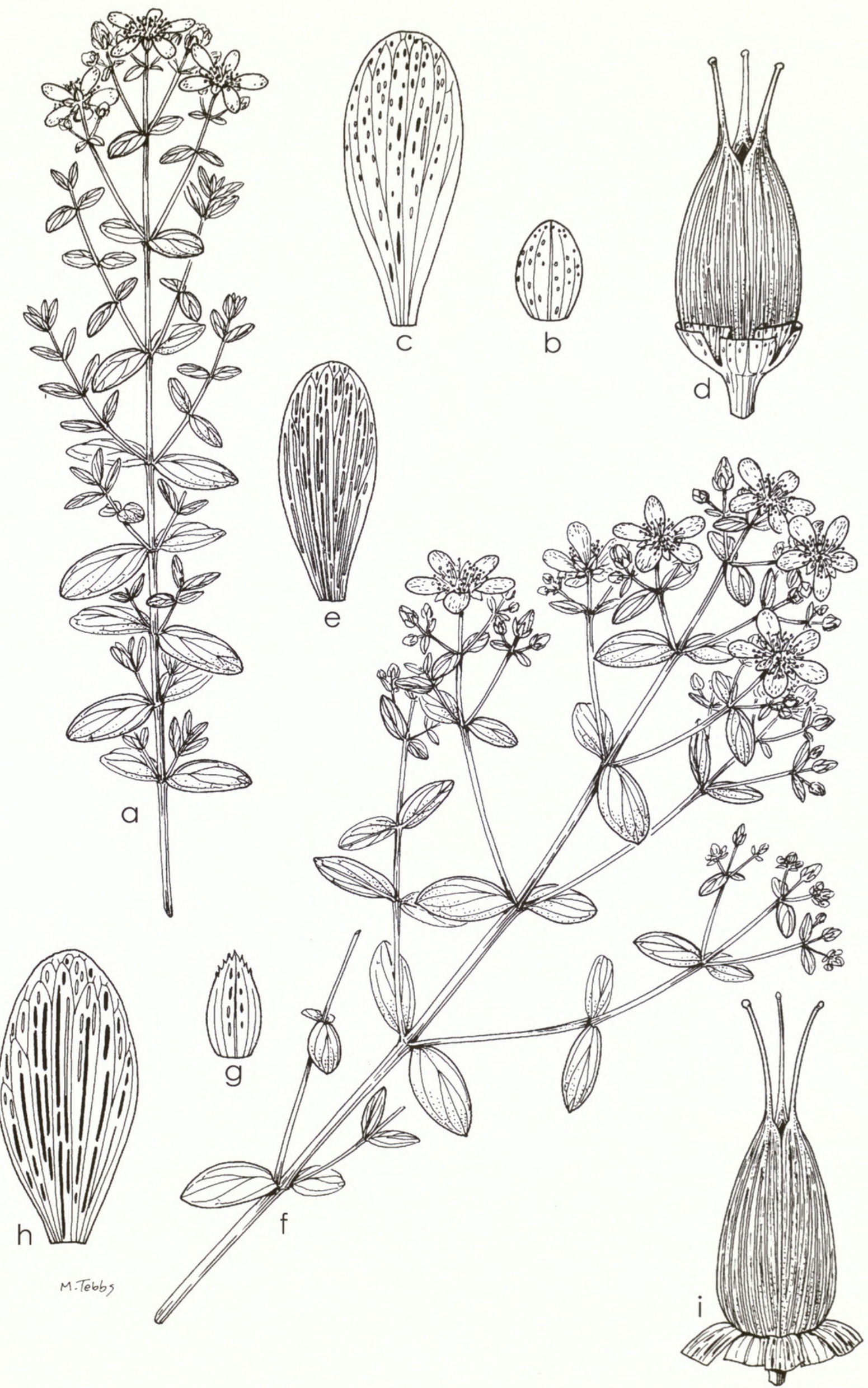

Fig. 6 A. H. maculatum subsp. maculatum: (a) habit; (b) sepal; (c) petal; (d) capsule. B. H. maculatum subsp. immaculatum: (e) petal. C. H. maculatum subsp. obtusiusculum: (f) habit; (g) sepal; (h) petal; (i) capsule (a, $\mathrm{f} \times 2 / 3$; rest $\times 4$ ). A. (a) Duvigneaud 77; (b, c) Meinertzhagen s.n.; (d) Lacaita 6402. 
Fl. Pen. balc. 1: 534 (1925); Hegi, Ill. Fl. Mitt.-Eur. 5(1): 518 (1925); Stjep.-Vesel. in Josifović, Fl. Srbije 3: 116 (1972). Type as for H. quadrangulum var. immaculatum Murb.

Fig. 6, Map 1.

H. quadrangulum var. immaculatum Murb. in Acta Univ. Lund. 27(5): 152 (1891); Beck in Ann. K. K. Naturhist. Hofmus. 10: 182 (1895). Type: Bosnia, Hercegovina, Velež planina, c. 1500 m, 27 July 1889, Murbeck s.n. (LD!-lectotype, selected here).

H. quadrangulum subsp. immaculatum (Murb.) Wettst., Beitr. Fl. Alban.: 36 (1892). Type as for H. quadrangulum var. immaculatum Murb.

H. immaculatum (Murb.) Vierh. in Mitt. Naturwiss. Vereins Univ. Wien II, 4: 62 (1906), Aufz. Simony Pfl.: 27 (1906).

H. maculatum subsp. immaculatum var. punctatum A. Fröhl. in Sitzungsber. Kaiserl. Akad. Wiss., Math. Naturwiss. Kl. 120(1): 549 (1911). Type: not seen, no specimen cited.

H. maculatum subsp. immaculatum var. epunctatum A. Fröhl. in Sitzungsber. Kaiserl. Akad. Wiss., Math.-Naturwiss. Kl. 120(1): 549 (1911). Type: not seen, no specimen cited.

H. maculatum var. immaculatum (Murb.) Guşul. \& Nyár. in Săvul., Fl. R. P. Roman. 4: 33 (1956); Stoj., Stef. \& Kitanov, Fl. Bulg. 2: 721 (1967); Jordanov \& Kož in Jordanov, Fl. R. P. Bulg. 4: 260 (1970); Robson \& Strid in Strid, Mtn Fl. Greece 1: 608 (1986); N. Robson in Cullen et al., Europ. Gdn Fl. 4: 60 (1995), in Wisskirchen \& Haeupler, Standardliste Farn-u. Blütenpfl. Deutschl.: 269 (1998). Type as for H. quadrangulum var. immaculatum Murb.

H. fallax subsp. immaculatum (Murb.) O. Schwarz in Drudea 5: 63 (1965).

Stems always with complete subsidiary lines. Leaves with densely reticulate tertiary venation; laminar gland dots pale, usually \pm dense, occasionally with a few black. Inflorescence branches narrowly ascending, making an angle of $c .30^{\circ}$ with stem. Flowers $15-35 \mathrm{~mm}$ in diam. Sepals broadly ovate, rounded to obtuse or somewhat acute, entire or minutely denticulate; laminar glands pale, striiform and punctiform. Petals entire, without or rarely with 1-3 black marginal glands; laminar glands pale, linear to striiform. Styles equalling ovary. $2 n=16$ ? (see p. 63 )

Subalpine meadows; (500-)1000-c. $2200 \mathrm{~m}$.

Southern Romania (Carpathians), western and southern Bulgaria, northern Greece, Makhedonia, southern Serbia, Bosnia, Montenegro, Kosovo.

ROMANIA. Guşuleac \& Nyárády (1956: 33) record 'var'. immaculatum from SE Transylvania (Odorhei, Codlea and Sibiu regions).

BULGARIA. Mikhaylovgrad: Predbalkan, Ostabhang des Midshur [Midzhor], 4 September 1958 (fl), K. Meyer 1140 (JE). Sofia: Cherni Vrŭkh [Mt Vitoşa], c. 1440 m, 23 July 1952 (fl), Vyhodčevski s.n. (H). Blagoevgrad: Rila Planina, in valle Ristritza, c. 1000-2000 m, 20 August 1907 (fl), Schneider \& Bergmann 878 (BM, K); Pirin, above Bansko, above L. Okoto, 2130 m, 27 July 1993 (fl), Jury 12071 (BM, RNG*); Rhodopen, Snešanka, 1900 m, 8 October 1958 (fr), K. Meyer 1985 (JE).

GREECE. Makedhonia: Drama, in monte Tsalakou ad septentriones ditionis 'Elatia', 1800 m, 18 August 1978 (fl), Greuter 16532 (BM, C); Serron, Mt. Vrondous, NE of summit, 1600 m, 27 July 1981 (fl), Farsakoglou, Franzén \& Strid 19538 (C).

MAKHEDONIA. Šar Mtns, Mt. Scardos, 2000 m, 29 May 1983 (o. fr), McClintock s.n. (BM).

SERBIA. Niš: ad [R.]Vlasina, July 1895 (fl), Adamovič s.n. (K).Kosovo: Bertiscus, in valle rivuli Dočanska Bistrica, 1200-1300 m, 17-19 July 1933 (fl), Rechinger f. \& Scheffer 1338 (BM).

BOSNIA. Sarajevo, Trebevic, 1600 m, 30 June 1931 (fl), Gilliat-Smith 2922 (K); Velež Planina, 5 July 1912, Sagorski s.n. (JE).

MONTENEGRO. Vasovavići [Vasojevićki], sub Varda, 19 July 1898 (fl), Baldacci It. Alban. VI 181 (BM, K); prope monast. Piva, July 1905, Rohlena s.n. (JE).

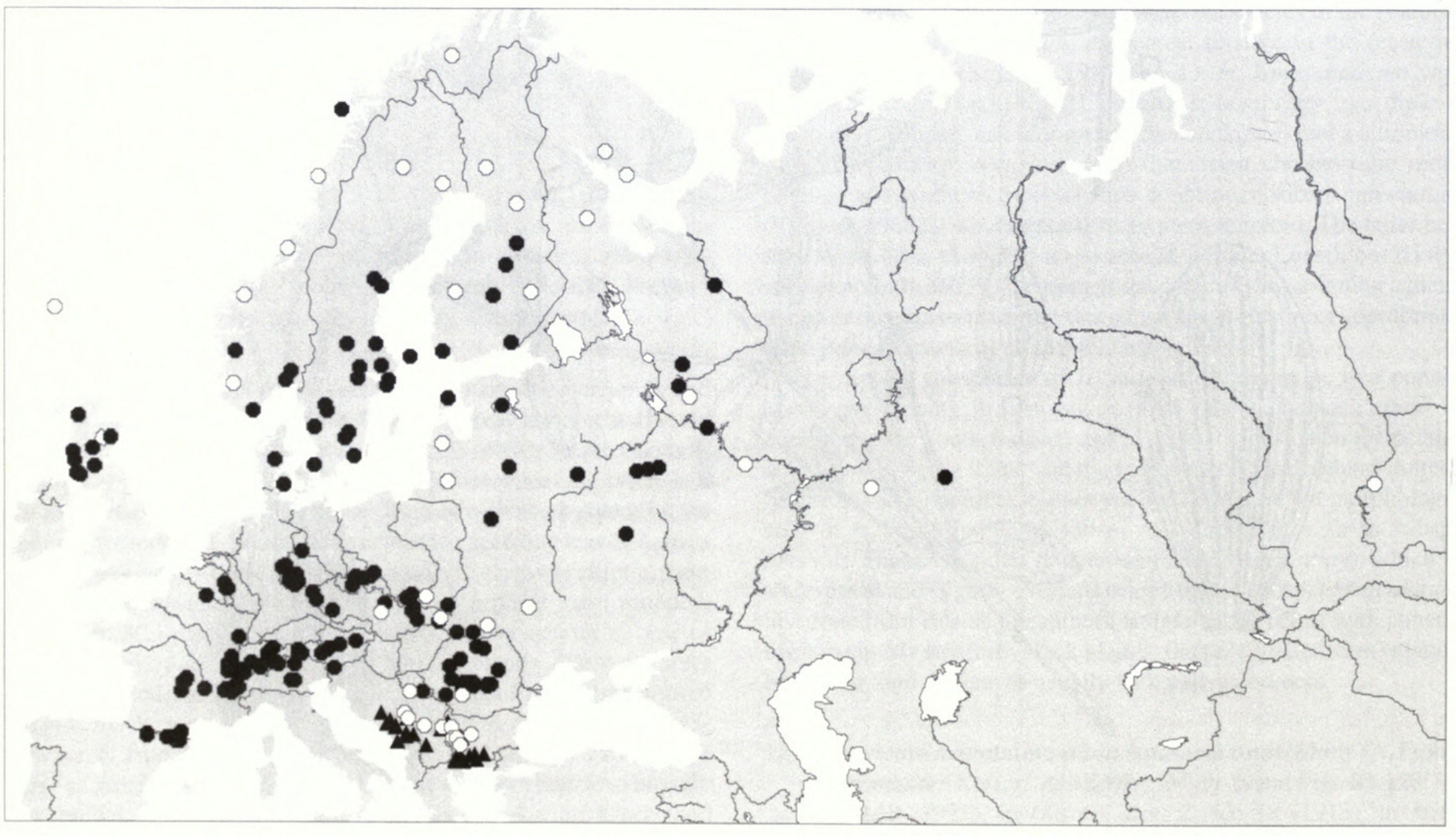

Map 1 1. H. maculatum. a. subsp. immaculatum b. subsp. maculatum ; other records $\mathrm{O}$. Widespread in Germany, but the records do not differentiate subspecies. 
Of the two diploid subspecies of $H$. maculatum, subsp. immaculatum would seem to be the more primitive and to constitute a relict Balkan population that has given rise to both subsp. maculatum and (by autotetraploidy) to subsp. obtusiusculum. It is also the nearest taxon morphologically to the H. tetrapterum group (Spp. 2-4) and would appear to be one parent of the allotetraploid 5. H. perforatum. The linear pale petal glands and usually glandular-punctate leaves both lead to the above conclusions, as do the punctate leaves and linear to striiform petal glands in H. perforatum (q.v.). A sheet from Greece (Makhedonia, Drama, Mt. Falakron, Stamatiadou 10131 (C)), with one plant with characters of subsp. maculatum among four plants of subsp. immaculatum, may indicate an independent development of punctate black laminar glands in the sepals and petals.

\section{1b. Hypericum maculatum subsp. maculatum}

Fig. 6, Map 1.

H. fallax Grimm in Nova Acta Phys.-Med. Acad. Caes. Nat. Cur. 3, App.: 362 (1767); O. Schwarz in Drudea 5: 62 (1965). Types: Germany, Sachsen, Eisenach, vor Winterstein, Grimm s.n. (JE?syntype), auf der Schlotwiese, Grimm s.n. (JE?-syntype), unten dem Inselberg, Grimm s.n. (JE?-syntype), um Mosbach, Grimm s.n. (JE?-syntype). Syntypes not found in JE.

H. delphinense Vill., Prosp. Hist. pl. Dauphiné: 44 (1779), Fl. delph.: 81 (1785), Hist. pl. Dauphiné 1: 281, 294, t. 44 (1786), 3: 497 (1789). Type: France, Isère, Oysans [Oisans], La Moncherolle, 1789 (fl), Villars MNHGr 1837. 28503 (GRM-photograph!lectotype, selected here).

H. tetragonum Fr., Fl. hall.: 124 (1818). Type: Sweden, Halland, 'copiose in pratis, aliud in Suecia non reperitur', Fries s.n. (UPSholotype). Fries rejected the name $H$. dubium for his plant.

H. dubium sensu Mauri, Roman. pl. cent. xiii: 27 (1820).

H. quadrangulum var. $[\gamma]$ sensu Choisy, Prodr. monogr. Hypéric.: 47 (1821).

H. quadrangulum sensu Fr., Novit. fl. suec.: 94 (1823); Spach, Hist. nat. vég., Phan. 5: 386 (1836), in Ann. Sci. Nat. Bot. 5: 357 (1836); Lamotte in Bull. Soc. Bot. Fr. 21: 122 (1874); Lange in Willk. \& Lange, Prodr. fl. hispan. 3: 591 (1878); J.D. Hooker, Student fl. Brit. Isles, 3rd ed.: 73 (1884); Schinz in Bull. Herb. Boissier II, 3: 15 (1902), in Vierteljahrsschr. Naturf. Ges. Zürich 49: 231-241 (1905); Tourlet in Bull. Soc. Bot. France 50: 307 (1903); R. Keller in Engl. \& Prantl, Nat. Pflanzenfam., 2nd ed. 21: 179 (1925); Druce, List Brit. pl., 2nd ed.: 64 (1928); Stefanoff in God. Agr. les. Fak. Univ. Sofiya 10: t. 2 f. 18, t. 4 f. 30 (1932), 11: 175, 177 (1933), 12: 88 (1934), in Pflanzenareale 4: Karten 6a, 8 (1933); Gorschkova in Shishkin \& Bobrov, Fl. U.R.S.S. 15: 242, t. 12 f. 3 (1949), et auct.; non L.

H. quadrangulum var. $[\gamma]$ maculatum (Crantz) Choisy in DC., Prodr. 1: 548 (1824). Type as for $H$. maculatum Crantz. Choisy cited ' $H$. maculatum Allioni', but Allioni (1785) cited Crantz.

H. commutatum Nolte, Novit. fl. holstat:: 69 (1826); Rchb., Fl. germ. exc., II: 837, no. 5180 (1830-1832), Icon fl. germ. helv. 6: t. 345 (1844); Bonnet in Bull. Soc. Bot. France 25: 276 (1878), qua hybr.; Rouy in Rouy \& Fouc., Fl. France 3: 335 (1896) qua hybr. Type: Germany, Schleswig-Holstein, in Duc Lauenburg prope pagum Büchen ad fl. Stechnitz, Nolte s.n. (B十-holotype). Fröhlich (1911: 547) saw Nolte's type and identified it as $H$. maculatum subsp. typicum var. punctatum (Schinz) A. Fröhl.

H. quadrangulum var. [b] subcorymbosum Schur, Enum. pl. Transsilv.: 132 (1866). Type as for H. commutatum Nolte.

H. quadrangulum var. [c] macrophyllum Schur, Enum. pl. Transsilv.: 132 (1866). Type: Romania, Transylvania, Kronstadt, July-August, Schur s.n. (BRNU? or LW?).
H. umbellatum Miel. ex Wohlf. in W.D.J. Koch, Syn. deut. schweiz. Fl., 3rd ed. 1: 429 (1892); A. Fröhl. in Sitzungsber. Kaiserl. Akad. Wiss., Math.-Naturwiss. Kl. I, 120(1): 557 (1911), pro syn.; nomen.

H. quadrangulum var. genuinum Schinz in Bull. Herb. Boissier II, 3: 21 (1902), in Vierteljahrsschr. Naturf. Ges. Zürich 49: 240, 241 (1905) sub subsp. quadrangulum, pro parte excl. typum. Type as for $H$. quadrangulum auct. non L., i.e. H. maculatum Crantz.

H. quadrangulum var. punctatum Schinz in Bull. Herb. Boissier II, 3: 20, 22 (1902), in Vierteljahrsschr. Naturf. Ges. Zürich 49: 240, 241 (1905) sub subsp. quadrangulum. Type: Switzerland, Graubünden, Oberengadin, Fornogletscher, Hegi s.n. (BR?holotype).

H. quadrangulum subsp. quadrangulum sensu Tourlet in Bull. Soc. Bot. France 50: 307 (1903); Schinz in Viertel-jahrsschr. Naturf. Ges. Zürich, 49: 231-241 (1905), pro parte excl. typum.

H. maculatum subsp. eu-maculatum Schinz \& Thell. in Schinz \& Keller, Fl. Suisse: 381 (1909); Thellung in Allg. Bot. Z. Syst. 1912: 24 (1912); A. Fröhl. in Oesterr. Bot. Z. 63: 18 (1913), in Mitt. Naturwiss. Vereines Steiermark 51: 223 (1915); Hegi, Ill. Fl. Mitt.-Eur. 5(1): 517 (1925). Type as for H. maculatum Crantz.

H. maculatum subsp. typicum A. Fröhl. in Sitzungsber. Kaiserl. Akad. Wiss., Math.-Naturwiss. Kl. I, 120(1): 540 (1911). Type as for H. maculatum Crantz.

H. maculatum subsp. typicum var. genuinum (Schinz) A. Fröhl. in Sitzungsber. Kaiserl. Akad. Wiss., Math.-Naturwiss. Kl. I, 120(1): 545 (1911). Type as for H. quadrangulum var. genuinum Schinz.

H. maculatum subsp. typicum var. punctatum (Schinz) A. Fröhl. in Sitzungsber. Kaiserl. Akad. Wiss., Math.-Naturwiss. Kl. I, 120(1): 545 (1911). Type as for H. quadrangulum var. punctatum Schinz. Fröhlich (p. 546) names forms glabrum and subnervosum (based on nervation) as well as rotundifolium and angustifolium (based on leaf shape) for both vars genuinum and punctatum; but giving the same epithet to infraspecific taxa within the same species is inadmissable (I.C.B.N. Art. 24, note 2). The epithet f. luteum, however, was given to subsp. typicum as a whole and would therefore appear to be valid.

H. maculatum subsp. typicum forma luteum A. Fröhl. in Sitzungsber. Kaiserl. Akad. Wiss., Math.-Naturwiss. Kl. I, 120(1): 546 (1911). Type: Austria, Styria, Puntigamer Güns (bei Graz), 16 July 1910 (fl), Fröhlich GZU 16228 (GZU!-lectotype, selected here).

H. maculatum subsp. quadrangulum sensu Hayek, Prodr. Fl. Pen. balc. 1: 534 (1925). Hayek cited 'H. quadrangulum Tourlet', i.e. H. maculatum Crantz not $H$. quadrangulum $\mathrm{L}$.

H. quadrangulum subsp. maculatum (Crantz) Goday \& Carbonell in Anales Inst. bot. Cavanilles 19: 380 (1961).

H. fallax Grimm subsp. fallax, O. Schwarz in Drudea 5: 63 (1965). H. fallax subsp. fallax Grimm var. fallax, O. Schwarz in Drudea 5: 63 (1965).

H. fallax subsp. fallax var. fallax forma punctatum O. Schwarz in Drudea 5: 63 (1965). Type not cited (JE).

H. fallax subsp. fallax var. quadrangulare sensu O. Schwarz in Drudea 5: 63 (1965) pro parte, quoad descr. Schwarz cited ' $H$. quadrangulare L. (1776)' as basionym.

H. maculatum subsp. maculatum forma punctatum (Schinz) Stjep.Vesel. in Josifović, Fl. Srbije 3: 116 (1972).

Icones: Rchb., Ic. fl. germ. helv. 6: t. 343 f. 5178 (1842-44); Gorschkova in Shishkin \& Bobrov, Fl. U.R.S.S. 15:188, t. 12 f. 3 (1949); Zelený et al. in Futák \& Bertová, Fl. Slovenska 3: t. 37 f. 1 (1982).

Stems always with complete subsidiary lines. Leaves with densely reticulate tertiary venation; pale glands usually absent but some- 
times few to numerous. Inflorescence branches narrowly ascending, making an angle of $c .30^{\circ}$ with stem. Flowers $15-25 \mathrm{~mm}$ in diam. Sepals broadly ovate to broadly elliptic or elliptic-oblong, entire or more rarely slightly eroded-denticulate; laminar glands pale and black, punctiform. Petals entire, without or rarely with 1-3 black marginal glands; laminar glands all or mostly black, punctiform or proximally shortly striiform. Styles equalling ovary. $2 \mathrm{n}=16$ (Noack, 1939; Robson, 1956, 1957; Schwarz, 1965; Reynaud, 1975; Dmetrieva, 1986; Parvenov \& Dmetrieva, 1987), n=8 (Nielsen, 1924; Winge, 1925; Robson, 1956, 1957, 1981; Laane, 1969).

Subalpine and alpine regions of the Pyrenees, Alps and Balkans; hilly regions further north (Massif Central, Vosges, Ardennes, Scotland); 0-2650 $\mathrm{m}$ (lowland in the north).

Distribution of the species except for lowland NW Europe (but with enclaves in the Ardennes and western and central Scotland) and valleys of the Alps east to Styria.

SCOTLAND. W. Ross: Ullapool, by Ullapool R., 16 August 1996 (fl \& e.fr), Kitchener s.n. (BM). Westerness: Sunart, Strontian, 13 July 1966 (bud), Cannon \& Kendrick s.n. (BM). Argyll: Dunadd area, between Lochgilphead and Kilmartin, July 1958 (fl), Kenneth s.n. (K). Arran: Lamlash, 10 August 1937, Mackechnie s.n. (BM). Lanark: Glenhove near Airdrie, 22 August 1951 (fl), Mackechnie s.n. (BM). Mid Perth: between Lawers and Fearnan, 3 September 1913 (fr), Marshall in B.E.C. 3787 (BM, K). S. Aberdeen: Aboyne, 9 August 1968 (fl), Robson s.n. (BM).

ENGLAND (introduced). Herts.: Gaddesden, The Hoe, 11 August 1962 (fl), J. \& C. Dony \& Allen s.n. (BM).

THE NETHERLANDS. Very rare. Records from Gelderland (1954), south of Limburg (1917), and near Nijmegen (1924), fide Mennema, QuenéBroterenbrood \& Plate (1980).

BELGIUM. Liège: Recht, 10 August 1977 (fl), Duvigneaud 77 B 737 (H). Namur: Cul-des-Sarts, Le Marais, 5 August 1977 (fl \& fr), Duvigneaud 77 B 704 (BM, H). Luxembourg: Vielsalm, bord de la Salm, 28 August 1935 (fr), Mosseray s.n. (BM, BR*).

FRANCE. Ardennes: près de Hulle, rive gauche de la Hulle, 14 August 1970 (fl), Duvigneaud 70 F 41 (H). Vosges: Ventron, Gerbamont, August 1880 (1. fl), Pierrat (BM, K). Doubs: Mont d'Or, 6 August 1851 (fl), Grenier s.n. (BM). Jura: Noirmont, près de Rousses, 6 August 1856 (fl), Michalet fam. 2, 67 (K). Haute-Savoie: Vallée de l'Arve, Vallon de Flaine/Cluses, $1700 \mathrm{~m}, 16$ July 1964 (fl), F. \& J.-D. Bersier 517 (G*,H). Savoie: Lanslebourg, 9 July 1884 (fl), Willmott (K). Isère: L'Oursière, près de Uriage, 1500-1600 m, 26 August 1880 (fl), Tillet (BM). Hautes-Alpes: Lauteret, 18 July 1931 (fl), Pugsley s.n. (BM). Alpes-de-Haute-Provence: Goudéissant, près Barcelonnette, 11 August 1854 (fl), Willmott s.n. (K). Loire: Mont Pilat, 1400 m, 14 July 1881 (fr), Glastien s.n. (BM). Puy-de-Dôme: le Mont-Doré, plateau de Durbise, 20 August 1928 (fl), Fiton in Duffour 5662 (BM). Cantal: Puy Mary, NW of Murat, 12 September 1966 (fl), Summerhayes 4202 (K). Haute-Garonne: Luchon, 14 July 1889 (fl), Murray s.n. (BM). Ariège: Ax, chemin d'Orgeix, n.d. (fl), de Martrin s.n. (K). PyrénéesOrientales: Mont-Louis, Ostrand der Wald von Font-Romeu, 7 August 1926 (fl), Ronniger s.n. (W). Hautes-Pyrénées: Gavarnie, 1350-1500 m, 30 August 1932 (fl), Meinertzhagen s.n. (BM).

ANDORRA. Ordino, 1250 m, 14 July 1962 (fl), Edwards \& Perry 9 (BM)

SPAIN. Gerona: [Santuario de] Nuria, Via Crucis, 3 August 1934 (fl), Dauder Rodés s.n. (BM). Lérida: Gorges de Llo, 1450 m, 29 August 1929 (fr), Sennen s.n. (BM). Teruel: Bronchales, Sierra Alta, 11 June 1962 (st), Kjellqvist \& Löve N588 (RNG).

ITALY. Val d'Aosta: Val Ferret, SE of Mont Blanc, 12 July 1854 (fl), Hort s.n. (BM). Novara: Val Formazza, Discesa da C. Cavala e S. Michele, 18271250 m, 3 August 1918 (fl), Boggiani s.n. (BM). Verona: Monte Baldo, 1000 m, June 1902 (fl), Rigo s.n. (H). Bolzano: Pusteria med., 1860-1950 m, 29 August 1871 (e. fr), Huter s.n. (BM). Treviso: Bosco Cansiglio (?), 1000 m, 10 July 1922 (fl), Fiori Fl. Ital. Exs. III 2664 (BM, K).

SWITZERLAND. Vaud: Alpen über Bex, 1832 (fl), Thomas in Reichenbach 1500 (BM, H, JE, WAG). Valais: Col du Lein, 1720 m, 29 July 1979 (fl), Lawalrée 21846 (BM, BR*). Bern: Mürren, 1590 m, 2 September 1923 (fr), Lester Garland s.n. (K). Graubünden: Tachitta Valley, near Preda,
Albula, 20 July 1928 (fl), Pugsley s.n. (BM). Glarus: Glärnisch Mtn, Glüterbach, 1150 m, 19 September 1963 (fr), Robson 1826(BM). Appenzell: am Gäbris ob Gais, July-August (fl), Schneider s.n. (BM).

AUSTRIA. Vorarlberg: Rätikon, 19 July 1952 (fl), Jacobs 3577 (L). Tirol: prope Trins in valle Gschnitz, c. 1100 m, n.d. (fl), Kerner in Fl. Exs. Austr.-Hung. 3647 (BM, H, JE, K). Salzburg: Radstadter Tauernpasshöhe, 1700-1300 m, 13 August 1932 (fl), Hübl s.n. (BM). Kärnten: Weissenfels Krain, September 1913 (st), Meebold s.n. (K). Steiermark: Schladming, 750 m, 3 July 1994 (fl), Townsend 94/34 (K). Niederösterreich: Montes Rax in valle Höllenthal, 600 m, August 1953 (fl), Patzak s.n. (H, W*).

GERMANY. Bayern: Kampenwald, above Steinlinghütte, 26 July 1934 (fl), Willmott s.n. (BM); Oberostdorf, 25 July 1927 (fl), Mann s.n. (FR). Hessen: Wasserkuppe gegen den Pferdskopf, c. 900 m, 9 August 1903 (fl), Goldschmidt s.n.(FR). Thüringen: Erfurt, bei Oberhof, Schmücke, $c .900 \mathrm{~m}$, 16 July 1952 (fl), Launert s.n. (BM); Suhl (?), Neuhaus (Reunsteig), 1950, K. Meyer s.n. (JE). Sachsen: bei Dresden, n.d. (fl), Horn in Reichenbach, Exs. Fl. Germ. 1397 (BM, H, JE). Sachsen-Anhalt: Harz, Minfra nach Harlingerode, 1858, (Collector?) (JE); Magdeburg, Werningerode, July 1860 (fl), (Collector?) (FR). Brandenburg: fide Ascherson (1864: 113). Berlin: Spandau, Finkelhang, 28 July 1867 (l. fl) Wagner s.n. (K). MecklenburgWest Pomerania: Schwerin, prope Gustrowiam, 1830, Jahn? s.n. (JE); Rügen I., 1958, Inst. Excurs. s.n. (JE).

DENMARK. Jylland: Frederikshavn, Pikkerbakken, 26 July 1968 (fl), Jensen, Nielsen \& Pedersen in Fl. Jtl. Exs. 465 (BM, H, TAI). Fyn: Dyreborg Skov, Faaborg, 24 July 1952 (fl), Young 4482 (BM). Sjaelland: Dyrhavn, Klampenborg, 15 August 1947 (fl), Price 307(?) (K).

FAEROE ISLANDS. Streymoy, Vágar (fide Jóhansen, 2000).

NORWAY. Akershus: As, near Ski, c. 48 km S. of Oslo, 29 July 1961 (fl), Goodfellow 61.1600 (BM, LIV*). Vestfold: Åsgårdstrand, 31 August 1934 (fr), Williams s.n. (BM). Vest Agder: Vigeland, Kristiansand, August 1909 (fl), Gamble 29773 (K). Rogaland: Stangaland, Eide, 14 August 1930 (fl), Rosseland s.n. (H). Hordaland: Hardanger Fjord, Utne, S. Bergenhus, 16 August 1934 (fr), Williams s.n. (BM). Nordland: Holandsfjord, c. 200 m, 22 July 1950 (fl), Boyd in Durham U. Exped. 346 (BM); Lofoten Is., Svolvaer, Svolvaergjeita, 27 July 1939 (fl), Blakelock 73 (K).

SWEDEN. Blekinge: Rödeby, Rödebyholm, 11 July 1989 (fl), Hult s.n. (H). Gotland: Öland I., Bredsätra sn., Bredsätra by, 15 August 1957 (fl), Saarsoo 7684 (H). Kronsberg: Söraby s. n. ö. om Stavsåkra, 4 August 1957 (fl), Saarsoo 7684 (H). Jönköping: Korsberga, Mölebo, 3 August 1908 (fl), Stalin s.n. (H). Skaraborg: Skara, 15 July 1908 (fl), Jacob \& Jacobson s.n. (BM). Ålvsborg: Skene, c. 700 m, nördlich Berghem station, 13 August 1965, Buttler \& Gaubl 7941 (FR). Örebro: Närke, Svennevad, Gropen, c. 75 m, 4 August 1950 (fl), Kjellmart s.n. (H). Stockholm: Stockholm, 23 July 1858 (fl), Nyman s.n. (BM). Uppsala: prope Upsaliem, July 1869 (fl), Ahlberg s.n. (BM). Vastmanland: Arboga, Hamnen, 19 July 1951 (fl), Fridell s.n. (H). Kopparberg: Leksands sn., Björkberg, 17 September 1956 (fl \& fr), Norrman s.n. (BM). Gävleborg: Gävle, Lovudden, 20 August 1964 (fl \& fr), Nannfeldt s.n. (BM). Västernorrland: Alno, 15 September 1909 (fl \& fr), Rönnblad s.n. (H).

FINLAND. Oulu: Kn. Kajaania, Likapuro, n.d., Heikkinen s.n. (JE). Keski-Suomi: Laukaa, Leppǎvesi Linnasaari, 30 July 1965 (fl), Valovirta s.n. (H). Kuopio: Savonia borealis, Iisalmi, Iimäki, 6 August 1975 (fl), Tallgrén s.n.(BM). Pohjois-Karjala?: Karelia austr., par. Vehkalahti, Pyhältö, 7 July 1961 (fl), Fagerström s.n. (BM). Turku Pori: Turku, Ruissalo, Laurila, 18 July 1968 (fl), Tallgrén s.n. (BM). Åland: Hammarland, Näfsby, 20 July 1968 (fl), Haakana s.n. (BM).

RUSSIA. Ladoga-IImen: Leningradsky obl., Lupskiy r-n., MerabushLupesíka, 13 July 1969 (fl), Nepli 18 (K). Dvina-Pechora: Archangelsk, Beresink, 1919 (fl), Grantham s.n. (BM). Upper Volga: Prov. Mosqua, prope urbe Noginsk, 30 June 1968 (fl), Samozvon 158A (H). Volga-Kama: Prov. Kostroma, distr. Kineschma, prope Pawlowskoje, 4 July 1903 (fl), Klementz 1970 (H). Upper Dnieper: Smolensk obl., Dukhovshchina distr., prope pag. Ovsianka (10 km NW of Preczistoe), 8 August 1974 (fl \& fr), Makarov \& Bazhenova s.n. (H). Middle Dnieper: fide Gorschkova (1949: 243). VolgaDon: Orël obl., Orlovsk, Ostrovakami, n.d. (l. fl), Tarachkova \& Poganki 317 (H). Transvolga: fide Gorschkova (1949: 243). Upper Tobol: Chelyabinsk, Ural, in vallibus montis Jurma, July 1844 (fl), [Buhse?] (Herb. Buhse). Ob: south, fide Gorschkova (1949: 243). Angara-Sayan: Ibryul' village, fide Gorschkova (1949: 243). 
ESTONIA. Ingria, Hietamäki, Nütty, 20 July 1915 (fl), Jamalainen s.n. (H); Dagö I. [Hüumaa], Emmaste, 1872, Winkler 335 (JE).

LATVIA. Krashavskiy r-n., Zabludovka, 13 July 1967 (fl), Makarova s.n. (H).

LITHUANIA. Throughout the Territory (Vilkevičiūté, 1971).

BELORUS. NiaDków, distr. Nowogródek [Novogrudok], 28 - 1898 (fl), Dybowski in Woloszczak, Fl. Polon. Exs. 715 (BM).

UKRAINE. *Rossia Subcarpatica: montes Vysoké Poloniny, polonina Rovná, c. 1300 m, 8 July 1938, Jirásek s.n. (PR). *Carpatorossia: Čorná Hora, in ... montis Hoverla, 1800-2056 m, July 1935, M. Deyl in PR 164845 (PR). Bucovina: in summis alpinis ... alpis Tschumaled, July 1833 (fl), Herbich s.n. (W).

POLAND. Jelenia Góra: Sudet, Hirschberg, 1 July 1958, Köhler \& Zippold s.n. (JE). Walbrzych: Sląsk Dolny, Spalona pow. Bystrzyca KX, 25 July 1958 (fl), Gołowin 157 (H). Wroclaw?: Breslau, Strachate, 28 July 1888, Kionka s.n. (JE). Bielsko Biala: distr. Wadowice, infra cas. Potrójna, 24 July 1938 (fl), Łancucka in Pl. Pol. Exs. 329a (BM, K). Tatry: Tatra, Zakopane, Dol. Maty Zaly, 11 July 1958, Köhler \& Zippold s.n. (JE). Krosno?: E. Carpath., Breskul, \pm 1450 m, 29 August 1938 (fl), Kosij in Pl. Pol. Exs. 329b (BM, K).

CZECH REPUBLIC. Bohemia: Montes Šumava, p. p. Hamny, 3 August 1962 (fl), Hostička s.n. (H); *distr. Cheb, in valle R. Libocký potock sub vico Opatov, ad Dolni mlýn, c. 560 m, 18 September 1950, Klášterský in PR 165161 (PR). Moravia: Weisskirchen bei Hrubuska, July 1911 (fl), Petrak 1142 (BM); *chalet Bunč near Salaš, 6 July 1987, Mártonfi 459 (KO).

SLOVAKIA. Michalovce, Vihorlat, oberhalb Remetske Hamre, c. $500 \mathrm{~m}$, 23 July 1974 (fl), F.K. \& J. Meyer 11006 (JE); *Bukovské vrchy Mts, near Runina, 31 July 1995, Mártonfi 2022 (KO); * pasture 'Voniarky' near Dobšiná, c. 915 m, 13 August 1991, Mártonfi 976 (KO).

HUNGARY. Absent?

SLOVENIA. Bled [Veldes], 1924 (fl), Leathes s.n. (BM).

CROATIA. Widespread (Schlosser \& Vukotinovi, 1869: 382).

SERBIA. North: Fruška Gora. Central: Suva planina, Stara planina, Tara planina, Zlatibor, Kopaonik (Stjepanovi-Veselichi, 1972).

ROMANIA. Transsilvania: Crişana, Bihor, ad Balneas Stâna de Vale, $c$. 1100 m, July 1936 (fl), Borza in Pl. Exs. Rom. 1520c (H, K); in monte ButkaKandrenulni ad Dorna-Kandreni [Dornişoara], July 1838 (fl), Herbich s.n. (W); *Munții Bihorlui Mts., above Scărişoara, c. 1400 m, 16 July 1995, Mártonfi 1985 (KO). Moldavia: Comm. Dărmăneşti, monte Nemira, c. 1500 m, 14 July 1970 (fl), Barabaş \& Şova 158 (H); *Distr. Turda-Arieş, Valea Morii prope oppid. Cluj, c. 600-650 m, 28 July 1923, E.I. Nyárády in CL 444000 (CL). Walachia: Oltenia, distr. Gilort, mont. Paring. ad Muşătoiu, $c$. 1540 m, 30 September 1960 (e. fr), Buia et al. in Fl. Olten. Exs. 52 (BM, H).

BULGARIA. Jordanov \& Kozhukharov (1970: 260) record var. maculatum from N. and W. Stara planina, the Znepolski region (Golo birdo), W. Granichni planina, the Vitoša region (Vitoša), Slavianka and Rila.

1c. Hypericum maculatum subsp. obtusiusculum (Tourlet) Hayek, Sched. fl. stiriac. 23-24: 27 (1912); Thellung in Allg. Bot. Z. Syst. 1912: 24 (1912); A Fröhl. in Oesterr. Bot. Z. 63: 13, 18 (1913), in Mitt. Naturwiss. Vereines Steiermark 51: 223, 224 (1915); Schinz \& Keller, Fl. Schweiz, 4th ed. 1: 451 (1923); Hegi, Ill. Fl. Mitt.-Eur. 5(1): 517 (1925); N. Robson in Bot. Soc. Brit. Isles Proc. 2: 237 (1957), in op. cit. 3: 99 (1958), in Tutin et al., Fl. Europ. 2: 268 (1968), in Wisskirchen \& Haeupler, Standardliste Farn- u. Blütenpfl. Deutschl.: 269 (1998). Type as for $H$. quadrangulum subsp. obtusiusculum Tourlet $=H$. desetangsii var. imperforatum Bonnet.

Fig. 6, Map 2.

H. dubium Leers, Fl. herborn.: 165 (1775); Sm., Engl. Bot.: 296 (1796), Fl. brit. 2: 802 (1800); Bab. in Trans. Bot. Soc. Edinburgh 1: 88 (1841), Man. Brit. bot.: 57 (1843); Bellynk, Fl. Namur: 52 (1855); Syme, Engl. Bot., 3rd ed. 2: 151 (1864); Schinz in Vierteljahrsschr. Naturf. Ges. Zürich 49: 231-241 (1905); Mártonfi et al. in Preslia 71: 337 (1999). Types: Germany, Hesse, 'ad sepes am Sieghaus', Leers s.n. (?-syntype); 'am Homberg', Leers s.n. (?-syntype). According to Stafleu \& Cowan (1979), Leers' herb- arium was taken to Russia (early in the nineteenth century?) and subsequently partly destroyed and partly lost. His description (apart from the ovate entire sepals) and the location of Herborn are both consistent with his plant's belonging to subsp. obtusiusculum; and broad entire sepals are not unknown in subsp. obtusiusculum, having been found in Kirkcudbrightshire, SW Scotland (see record, p. 75), and they were recorded by Tourlet (1903). They also occurred in a plant of subsp. maculatum in which the chromosomes had been doubled by colchicine treatment (Robson, 1956, 1957, 1981). Schinz, in the paper cited above, discussed the name $H$. dubium but treated it as a synonym of $H$. quadrangulum in his sense, i.e. H. maculatum Crantz. Fröhlich (1911) also regarded $H$. dubium as a synonym of $H$. maculatum (i.e. subsp. typicum).

H. obtusum Moench, Methodus: 129 (1794), nom. illegit. Type as for $H$. dubium Leers.

H. leersii C.C. Gmel., Fl. bad. 3: 253 (1808); 5: 575 (1826), nom. illegit. Type as for $H$. dubium Leers.

$H$. quadrangulum var. $[\beta]$ sensu Choisy, Prodr. monogr. Hypéric.: 47 (1821).

H. quadrangulum var. $[\beta]$ dubium (Leers) Choisy in DC., Prodr. 1: 548 (1824), pro parte excl. syn. H. delphinense Vill.

H. dubium var. [ $\beta$ ] maculatum sensu Bab., Man. Brit. bot., 3rd ed.: 58 (1851), i.e. sensu H. dubium Bab. in Trans. Bot. Soc. Edinburgh 1: 88 (1841), Man. Brit. bot.: 57 (1843), 2nd ed.: 60 (1847).

H. dubium var. $[\alpha]$ genuinum Syme, Engl. Bot., 3rd ed. 2: 151 (1864).

Holosepalum dubium (Leers) Fourr. in Ann. Soc. Linn. Lyon, N.S. 16: 352 (1868).

?Hypericum quadrangulum var. [b] ambiguum Schur in Verh. Naturf. Vereins Brünn 15(2): 158 (1877). Type: Czech Republic, Moravia, oberhalb der Mazocha bei Blansko, August 1871, Schur s.n. (BRLU? or LW?).

H. desetangsii var. [ $\beta]$ imperforatum Bonnet in Bull. Soc. Bot. France 25: 277 (1879); Schinz in Bull. Herb. Boissier II, 3: 14 (1902), in Vierteljahrsschr. Naturf. Ges. Zürich 49: 241 (1905). Type: France, Seine-et-Oise, Meudon, 11 August 1878 (1. fr), Bonnet in Soc. Dauphinoise 1998 (P-lectotype, selected here; CLF!, FR!, K!-isolectotypes). My preliminary selection of lectotype for this variety, Lloyd's specimen from Loire-Inférieure [Loire-Atlantique], was published by Mártonfi et al. (1999: 339) as 'Robson, in prep.'. Neither they nor I have seen this specimen, and the more widely distributed Bonnet exsiccata cited above would seem to be a more appropriate choice.

H. quadrangulum var. occidentale Franch., Fl. Loir-et-Cher: 97 (1885); Rouy in Rouy \& Fouc., Fl. France 3: 335 (1896). Types: France, Loir-et-Cher, environs de Mondoubleau, 16 July 1867 (fl), Legué s.n. (P!-lectotype, selected here); bois de Roquelane, August 1864 (fl), Legué s.n. (P!-syntype); Onzain, petit bois de Mare, Monin s.n (?-syntype, not lectotype as cited in Mártonfi et al., 1999: 339). The last specimen has not been found in P.

H. acutum subsp. desetangsii var. imperforatum (Bonnet) Rouy in Rouy \& Fouc., Fl. France 3: 337 (1896), comb. illegit. Type as for $H$. desetangsii var. imperforatum Bonnet.

H. quadrangulum subsp. obtusiusculum Tourlet in Bull. Soc. Bot. France 50: 307 (1903). Type as for $H$. desetangsii var. imperforatum Bonnet. Tourlet describes $H$. quadrangulum subsp. quadrangulum on the same page in the sense of $H$. tetrapterum $\mathrm{Fr}$.

$H$. quadrangulum subsp. obtusiusculum var. $[\alpha]$ imperforatum (Bonnet) Tourlet in Bull. Soc. bot. France 50: 308 (1903). Type as for $H$. desetangsii var. imperforatum Bonnet, i.e. this is subsp. obtusiusculum Tourlet var. obtusiusculum.

$H$. quadrangulum subsp. obtusiusculum var. [ $\beta]$ perforatum Tourlet 


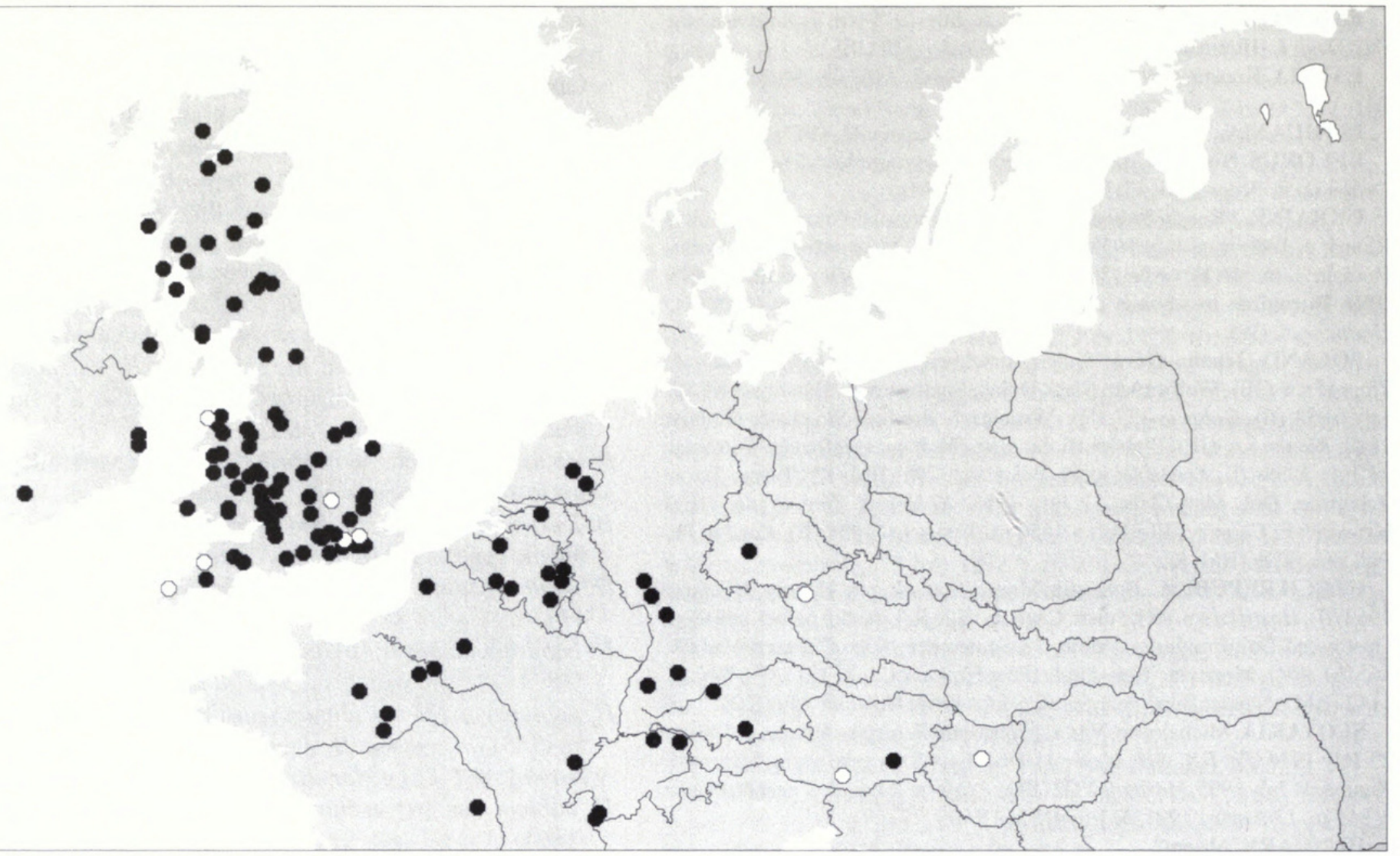

Map 2 1c. H. maculatum subsp. obtusiusculum $\bullet$, other records O. French and German records probably incomplete, as are the Irish ones.

in Bull. Soc. Bot. France 50: 308 (1903). Type: France, Indre-etLoire, vallon de la Desmée, [Les] Hermites, Doucet s.n. (G?holotype).

H. maculatum var. [ $\beta$ ] babingtonii H. \& J. Groves, Man. Brit. bot. 9th ed.: 74 (1904). Type as for H. dubium var. maculatum sensu Bab., i.e. H. dubium Leers.

$H$. quadrangulum subsp. erosum var. epunctatum Schinz in Vierteljahrsschr. Naturf. Ges. Zürich 49: 240, 241 (1905), nom. illegit. (Art. 52.1). Type as for $H$. desetangsii var. imperforatum Bonnet. Schinz, in order not to provide an unnecessary synonym and in support of the Rules of Nomenclature, named this form [sic] epunctatum.

H. quadrangulum subsp. erosum var. punctatum Schinz in Vierteljahrsschr. Naturf. Ges. Zürich 49: 240, 241 (1905), nom. illegit. (Art. 52.1). Type as for H. quadrangulum subsp. obtusiusculum var. perforatum Tourlet.

H. maculatum subsp. erosum sensu Schinz \& Keller, Fl. Suisse: 381 (1909); A. Fröhl. in Sitzungsber. Kaiserl. Akad. Wiss., Math.Naturwiss. Kl., 120(1): 550 (1911).

H. maculatum subsp. erosum var. imperforatum (Bonnet) A. Fröhl. in Sitzungsber. Kaiserl. Akad. Wiss., Math.-Naturwiss. Kl. 120(1): 553 (1911). Type as for $H$. desetangsii var. imperforatum Bonnet.

H. maculatum subsp. erosum var. perforatum (Tourlet) A. Fröhl. in Sitzungsber. Kaiserl. Akad. Wiss. Math.-Naturwiss. Kl. 120(1): 553 (1911). Type as for $H$. quadrangulum subsp. obtusiusculum var. perforatum Tourlet.

H. maculatum subsp. erosum var. imperforatum forma latisepalum A. Fröhl. in Sitzungsber. Kaiserl. Akad. Wiss., Math.-Naturwiss. Kl. 120(1): 554 (1911), in Mitt. Naturwiss. Vereines Steiermark 51: 221 (1915). Type: Austria, Styria, bei Doblad, 22 August 1909 (fr), Fröhlich GZU16202 (GZU!-lectotype, selected here). Note: none of Fröhlich's combinations of his formae under subsp. obtusiusculum in 1915 (p. 221) were effective.
H. maculatum subsp. erosum var. imperforatum forma latisepalum [sub]forma nigrum A. Fröhl. in Sitzungsber. Kaiserl. Akad. Wiss., Math.-Naturwiss. Kl, 120(1): 554 (1911), in Mitt. Naturwiss. Vereines Steiermark 51: 221 (1915). Type: Austria, Styria, Ragnitz bei Graz, July 1909 (fl), Fröhlich GZU16194 (GZU!-lectotype, selected here).

H. maculatum subsp. erosum var. imperforatum forma latisepalum [sub]forma lucidum A. Fröhl. in Sitzungsber. Kaiserl. Akad. Wiss, Math.-Naturwiss. Kl. 120(1): 554 (1911), in Mitt. Naturwiss. Vereines Steiermark 51: 221 (1915) sub var. imperforatum (Bonnet) Fröhl. Type: Austria, Styria, bei Stattegg, nach Graz, 10 July 1910 (fl), Fröhlich GZU16200 (GZU!-lectotype, selected here).

H. maculatum subsp. styriacum A. Fröhl. in Mitt. Naturwiss. Vereines Steiermark 51: 222, 224 (1915); Hegi, Ill. Fl. Mitt.-Eur. 5(1): 518 (1925). Type: Austria, Styria, ad vicum Maria-Trost prope urbem Graz, c. 430 m, July 1911 (fl), Fröhlich in Hayek, Fl. Stir. Exsicc. 1198 (GZU!-lectotype, selected here, BM!, GB!, H!; K!-photographs; see also Mártonfi et al., 1999: 340).

H. maculatum subsp. obtusiusculum var. perforatum (Tourlet) A. Fröhl. in Mitt. Naturwiss. Vereines Steiermark 51: 243 (1915). Type as for $H$. quadrangulum subsp. obtusiusculum var. perforatum Tourlet.

H. maculatum subsp. obtusiusculum var. imperforatum (Bonnet) A. Fröhl. in Mitt. Naturwiss. Vereines Steiermark 51: 243 (1915). Type as for $H$. desetangsii var. imperforatum Bonnet.

H. dubium var. perforatum (Tourlet) Pugsley in J. Bot. 78: 35 (1940). Type as for H. quadrangulum subsp. obtusiusculum var. perforatum Tourlet.

H. erosum (Schinz) O. Schwarz in Drudea 5: 63 (1965) pro parte excl. typum.

Icones: Syme, Engl. Bot., 3rd ed. 2: t. 269 (1864); Ross-Craig, Draw. Br. Pl. 6: t. 8 (1952). 
Stems with subsidiary lines present or sometimes partly (or wholly?) absent. Leaves with rather dense tertiary venation (somewhat laxer than in subsp. maculatum); laminar gland dots pale, dense to very sparse or absent. Inflorescence branches widely ascending, making an angle of $c .50^{\circ}$ with stem. Flowers $25-30 \mathrm{~mm}$ in diam. Sepals broadly to narrowly ovate, with apex finely eroded-denticulate or rarely entire. Petals usually distally unilaterally crenate with marginal black glands in depressions?; laminar glands pale and black or rarely only pale, linear to striiform and sometimes punctiform. Styles 1-2 × ovary. 2n=32 (Robson, 1956, 1957, 1958a).

Montane regions and valleys in the Alps, lowland further north, in meadows, rough pasture and damp woods; 0-c. $850 \mathrm{~m}$.

North-west Europe east to western Germany and Bohemia (except most of western Scotland), valleys of the Alps east to Styria, western Hungary. Introduced into Canada (British Columbia).

SCOTLAND. E. Sutherland: Lairg, 24 July 1961 (fl), Mc Callum Webster 5726 (K). Easterness: Inverness, Clashnaharry, 3 October 1975 (fr), McCallum Webster 18700 (BM). Moray: Brodie Castle, 3 August 1961 (fl), McCallum Webster 5848 (K). S. Aberdeen: Drum, R. Dee by Old Manse, 15 August 1956 (fl \& fr), Robson s.n (BM). W. Perth: Callander, 16 July 1989 (fl), N.F. Stewart s.n. (BM). Mid Ebudes: Mull, between Glen Forsa Lodge entrance and Forsa bridge, July 1984 (fl), Stirling s.n. (BM). Kintyre: near Fairy Isles, 28 July 1979 (fl), Kenneth s.n. (BM). Selkirk: banks of R. Ettrick near Selkirk, July 1926 (fl), Hayward s.n. (BM). Renfrew: near Gourock, 17 July 1899 (fl), Pugsley s.n. (BM). Dumfries: Applegarth, Perchall, 8 August 1957 (fl), Bangerter \& Collett 381 (BM). Kirkcudbright: Rockcliffe, August 1999, Tregale s.n. (Herb. Tregale).

ENGLAND. Westmorland: Tebay, Low Borrowbeck, 31 July 1991, Halliday 72/91 (BM). N.B. The records of subsp. maculatum in Cumbria (Halliday, 1997: 578) all proved to be subsp. obtusiusculum. NW Yorks.: near Richmond, 22 August 1842 (fl \& fr), J. Ward s.n. (BM). W. Lancs.: near Whittingham, Coney Garth Lane, September 1982 (fr), L. \& P. Livermore s.n. (LIV). Cheshire: below Overton Scar, 15 July 1909 (fl), Wolley Dod s.n. (BM). Leicester: Ulverscroft, 10 August 1890 (e. fr), A.B. Jackson s.n. (BM). N. Lincs.: Woodhall Spa, 6 August 1945 (fl), Alston s.n. (BM). Shropshire: near Ludlow, Bringwood Chase, August 1935 (e. fr), Ross s.n. (BM). Warwicks.: Brandon, 17 July 1925 (fl), Riddelsdell s.n. (BM). Hereford: near Ross, Chase Wood, 19 July 1915 (fl), Adamson s.n. (BM). E. Gloucs.: Brimscombe, 3 August 1953 (e. fr), Townsend s.n. (K). Bedford: Potsgrove, 7 July 1945 (fl), Dony s.n. (BM). W. Norfolk: Dersingham, 16 July 1949 (fl), Libbey 3229 (BM). Oxford: near Hempton, 30 October 1930 (fr), Riddelsdell s.n. (BM). N. Essex: near Quendon, 25 July 1942 (fl), Pugsley s.n. (BM). W. Kent: near Ide Hill, 13 July 1939 (fl), C.E. Britton 4322 (BM). W. Sussex: Midhurst, West Lavington, 7 July 1934 (fl), N.D. Simpson 34220 (BM). Dorset: between Crendell and Daggins, 2 August 1934 (e. fr), Good 484 (BM). E. Cornwall: near Rilla mill, 6 September 1948 (fl), Alston s.n. (BM).

WALES. Glamorgan: near Lisvane, 3 July 1968 (fl), Pinkard s.n. (H). Pembroke: Caneston wood, 11 August 1931 (fl), Alston s.n. (BM). Merioneth: Dolgelly, Bontnewydd, 8 August 1923 (fr), Barton s.n. (BM). Radnor: Llangullo station, 5 August 1956 (fl), P.C. \& J. Hall s.n. (BM). Denbigh: Llanrwst, 9 August 1930 (fl), Holder 464 (LIV). Anglesey: Benllech, 5 July 1911 (fl), Cooper s.n. (BM).

IRELAND. Kerry: Killarney, 30 July 1885 (fl), Linton s.n. (BM). Clare: $0.8 \mathrm{~km} \mathrm{~W}$. of Ballynalacken Castle, 1 August 1962 (fl), Moore 459 (BM). Galway: Co. Galway, July 1854 (fl), More s.n. (BM). Wicklow: near Roundswood, 31 August 1962 (fl), McCallum Webster 7981 (K). Antrim: Belfast, Shaw's Bridge, 24 August 1872 (fr), Stewart (BM). Fermanagh: Inver Lough, 19 July 1957 (fl), Meikle 2127 (K).

NETHERLANDS. Overijssel: near Mokkelengoor, S. of Ijpelo, 14 June 1947 (fl), van Royen s.n. (H). Gelderland: s' Hertogenbosch, Meteren, Tielenwaard, 22 July 1974 (1. fl), Hekking s.n. (BM).

BELGIUM. Oost Vlanderen: Hamme Mille (?), 11 July 1953 (fl), Pierart s.n. (K). Liège: Spa, September 1876 (fr), C.H. Wright s.n. (K). Hainault: bois d'Obourg, 4 July 1867 (e. fr), Martinis in Pl. rar. crit. Belg. VI, 269 (BM). Namur: Crupet, près du confluent du Crupet et du Bocq, 8 August 1978 (fl), Lawalrée 21100 (BM, *BR). Luxembourg: La Roche [-enArdennes], August 1960 (l. fl), Dubois 1635 (BM, *BR).
FRANCE. Pas de Calais: Hersin[-Coupigny], 15 July 1917 (l. fl), G.C. Brown s.n. (BM). Aisne: la fôret de Retz près Villers-Cotterêts, 3 September 1878 (e. fr), Bonnet s.n. (K). Seine-et-Oise: Bois de Meudon, près l'Étang de Colm Porche, 19 August 1877 (fl), Delacour s. n. (K). Loire-Atlantique: bord de la Divatte, 5 August 1886 (fl \& e. fr), Lloyd s.n. (BM). Orne: Alençon, route de Fresnay, 19 July 1891 (1. fl), Beaudoin in Soc. Dauph. II 599 (BM). Allier: Cresset, bord du Sichon, 27 July 1867 (e. fr), Genevier s.n. (BM). Doubs: Mouthier, 15 July 1927 (fl), Williams s.n. (BM).

GERMANY. Hessen: Königstein/Taunus, NW der Stadt, 20 August 1961 (f1), Schaarschmidt 257 (FR); Kreis Limburg-Weilburg, Weilburger Lahntal, Weilburg, 260 m, 22 July 1978 (fl), Kalheber 78-527 (H). Thüringen: Weimar, Ettersburg, September 1923, Bornmüller s.n. (JE). BadenWürttemberg: Schwarzwald, Heselbach, 9 August 1931 (fr), Williams s.n. (BM). Bayern: Schwaben, Leipheim/Donau, Donauried, 7 July 1961 (fl), Doppelbaur 488 (H); Oberbayern, nahe dem Westüfer des Staffelsees, $650 \mathrm{~m}$, 11 August 1957 (fl), Launert s.n. (BM).

SWITZERLAND. Valais: Col de Balme, 30 August 1868 (fr), G. Engelmann s.n. (WIS). Zürich: oberhalb Oberglatt, c. 420 m, 3 September 1936 (fr), W. Koch s.n. (H). St. Gallen: Fürstenland, Gem. Waldkirch, Tannenberg, c. 850 m, 31 July 1948 (fl), W. Koch 48/473 (H).

AUSTRIA. Steiermark: ad vicum Maria-Trost prope urbem Graz, c. 430 m, July 1911 (fl), Fröhlich in Hayek, Fl. Stir. Exs. 1198 (BM, GB photograph, GZU, H, K photograph). Kärnten: fide Fröhlich (1915: 223).

CZECH REPUBLIC. Bohemia: *Doupovské Hory Mts, E. from Karlovy Vary, near Bražec, c. 685 m, 12 July 1996, Mártonfi 2125 (KO).

HUNGARY. Veszprém: *Montes Bakony, inter stationem ferroviae PorvaCsesznek ad pagum Borzavár, c. 400 m, 9 July 1934, Polgár in BP 261467 (BP); *in fossis Nádaser pr. villa Dobospuszta iuxta pag. Sáska, 27 July 1954, Szalay s.n. (ZIRC).

CANADA (introduced). British Columbia: Prince Rupert, September 1939 (fl), King UBC 21544 (UBC); Burnaby Mountain, 1 August 1990 (l. fl), Lomer UBC 202196 (UBC); Pemberton, 2 August 1946 (fr), Eastham UBC 14970 (UBC); North Vancouver, Capitano R. estuary, 8 August 1990 (fl), Lomer UBC 202195 (UBC).

The presence of linear glands (sometimes pale) in the petals and the greater frequency of pale glands in the leaves suggest that subsp. obtusiusculum has evolved from subsp. immaculatum, not, as I thought from my own observations and experiment, from subsp. maculatum. The plant obtained by colchicine doubling of the chromosomes (Robson, 1957, 1958a) had broad leaves, broad entire sepals and black petal laminar glands, as was to be expected starting from var. maculatum; but the inflorescence branching was wide and the petal glands (as far as I can remember in the absence of a specimen) were mostly linear. The presence of broad entire sepals in this experimental plant, in Leers's (lost) type of $H$. dubium and in a collection from Applegarth, Dumfries, SW Scotland (Bangerter \& Collett $381(\mathrm{BM})$ ), suggests that the frequent occurrence today of narrow oblong sepals and incomplete subsidiary stem lines may have resulted from recent introgression from $H$. perforatum.

Schwarz (1965) recorded $2 \mathrm{n}=16$ for ' $H$. erosum' (= subsp. obtusiusculum) and $2 \mathrm{n}=24$ for its hybrid with $H$. perforatum, adding that all his material gave the diploid number. Unless his results are duplicated in the future (which would necessitate a revision of the view adopted here), one must assume that his material was misidentified.

1x. Hypericum $\times$ laschii A. Fröhl. in Mitt. Naturwiss. Vereines Steiermark 51: 244, 245 (1915), in Preslia 32: 97-99, ff. 1, 2 (1960); Guşul. \& Nyár. in Săvul., Fl. R. P. Roman. 4: 46 (1956). Type as for H. tetraptero-quadrangulum Lasch.

1. H. maculatum $\mathrm{Crantz} \times 3$. H. tetrapterum Fr.

H. tetraptero-quadrangulum Lasch in Linnaea 4: 414 (1829). Type: Germany, Brandenburg, Driesen, 1829 (fl \& fr), Lasch s.n. (B†holotype).

H. maculatum Crantz $\times H$. acutum Moench sensu A. Fröhl. in 
Sitzungsber. Kaiserl. Akad. Wiss., Math-Naturwiss. Kl. 120(1): 584 (1911).

In comparison with $H$. tetrapterum: Stems relatively narrowly 4winged. Leaves usually rather densely veined, with pale glands numerous, some large and some small. Sepals relatively broad, obtuse to rather acute. Flowers about twice as large.

For distribution see under nothoformae.

The name $H . \times$ laschii applies to all hybrids between $H$. tetrapterum and $H$. maculatum, but only crosses involving subspp. maculatum and obtusiusculum are recorded. It therefore occurs in diploid $(2 n=16)$ and triploid $(2 n=24)$ forms, depending on which subspecies of $H$. maculatum is involved. Nearly all records are of crosses involving subsp. maculatum (diploid), but Fröhlich (1911) described one that appears to involve subsp. obtusiusculum (i.e. it would be triploid). The syntype populations of $H \times$ desetangsii Lamotte from near Troyes (Aube, France) appear to be an example of this latter cross (nothoforma froelichii), not, as all authors after Bonnet (1879) have assumed, of $H$. maculatum $\times$ perforatum. Bonnet, himself, stated that it was 'intermédiaire entre la suivante [H. tetrapterum] et l'H. quadrangulum [H. maculatum]'. In the interests of nomenclatural stability, however, I have retained the current usage. The type of $H$. intermedium Bellynck has also proved to belong to $H$. $\times$ laschii nforma froelichii. A proposal to conserve the name $H$. $\times$ desetangsii with a new type will therefore have to be made. Such a proposal would also conserve it against possible threats from $H$. mixtum $\mathrm{Du}$ Moulin and H. commutatum Nolte (see p. 104).

\section{1xa. Hypericum $\times$ laschii nothoforma laschii}

1a. H. maculatum subsp. maculatum $\times 3$. H. tetrapterum $\mathrm{Fr}$.

H. maculatum Crantz subsp. typicum A. Fröhl. $\times$ acutum Moench sensu A. Fröhl. in Sitzungsber. Kaiserl. Akad. Wiss., Math.Naturwiss. Kl. 120(1): 582, f. 12 (1911).

Icon: Rchb., Ic. fl. germ. helv. 6: t. 344, no. 5178 (1842-1844) [quadrangulo-tetrapterum].

Intermediate in height and habit between the parents. Leaves with tertiary venation usually relatively densely reticulate. Sepals $c$. $0.5-$ $0.75 \times$ petals, obtuse to acute, with pale striiform laminar glands. Petals entire, with pale or pale and black punctiform and striiform laminar glands.

FRANCE. Cher: Achères, 20 July 1909 (fl), Imbault s.n. (FR). Rhône: Arnas, August, 1878 (fl), Gandoger Fl. Gall. Exs. 407 (H). Tarn: Anglès, 23 July 1911 (fl \& fr), d'Alleizette s.n. (CLF).

SWITZERLAND. Schwyz (Einsiedlen), Zürich? (Geissboden), fide Fröhlich (1911).

AUSTRIA. Salzburg (Salzburg), Oberösterreich (Ischl), fide Fröhlich (1911)

CZECH REPUBLIC. Moravia: Bad Luhaovice, fide Fröhlich (1960).

SLOVAKIA. Bad Kovaovâ (near Zvolen), fide Fröhlich (1960).

GERMANY. Bayern: Kreis Augsburg, östlich Reinhartshausen, 5 August 1966 (fl), Petermann s.n. (H). Thüringen: Feun (with parents), August 1977 (fl), Schulze s.n. (FR). Berlin: Bredower Forst bei Berlin, August 1864 (fr), O. Kuntze (BM).

POLAND. Jelenia Góra: Schoenau [Zwierzawa], Polnisch-Hundorf, 4 June 1897 (fl), Scholz s.n. (H). Zielona Góra: Grünberg [Zielona Góra], Lindenbusch, 31 August 1892, Hellwig in Callier 576 (JE).

DENMARK. Fyn: Svendborg Fioniae, July 1872 (1. fl), Lange s.n. (K).

SWEDEN. Malmöhus: Helsingborg, 1 September 1897 (fl \& fr), Strandmark s.n. (H); also several other collections from extreme SE Skåne.

This hybrid may be expected to occur anywhere within the wide area of overlap of the distributions of the parents; but, on account of the differing habitat requirements of the parents, it is rare. 1xb. Hypericum $\times$ laschii nothoforma froelichii N. Robson, hybr. nov. Type: Austria, Styria, Ragnitz bei Graz, c. 400 m, 31 July 1909 (fl \& fr), Fröhlich GZU16255 (GZU!-holotype).

1c. H. maculatum subsp. obtusiusculum $\times 3$. H. tetrapterum Fr.

H. quadrangulum sensu Des Étangs in Mém. Soc. Agric. Dép. Aube 10: 24 (1841).

?H. tetrapterum var. [ $\beta]$ intermedium Coss. \& Germ., Fl. descr. anal. Paris: 64 (1845). This variety is described as intermediate between $H$. tetrapterum and H. quadrangulum (i.e. H. maculatum), of which the only subspecies in the Paris region is subsp. obtusiusculum.

H. intermedium Bellynck, Fl. Namur: 31 (1855); Gren., Fl. jurass. 1: 154 (1863); Nyman, Consp. fl. eur: 133 (1878); non Steud. (1847). Type: Belgium, Namur, Wépion, Dave s.n. (BR!holotype).

H. maculatum Crantz subsp. erosum sensu Schinz \& Keller. $\times H$. acutum Moench sensu A. Fröhl. in Sitzungsber. Kaiserl. Akad. Wiss., Math.-Naturwiss. Kl. 120(1): 588, f. 13 (1911).

Intermediate in height $(c .0 .6 \mathrm{~m})$ and habit between the parents. Leaves with tertiary venation laxly reticulate. Sepals $c$. $0.5 \times$ petals, broadly to narrowly oblong or narrowly elliptic (sometimes in same flower), obtuse to acute or subacuminate, entire to apiculate-eroded, with pale punctiform and striiform and single black linear laminar glands.

Very rare, probably as a result of the differing habitat requirements of the parents. Austria.

AUSTRIA. Steiermark: Ragnitz bei Graz, 15 July 1910 (fl), Fröhlich GZU 16256 (GZU).

This hybrid was known from the type locality only (but probably includes the types of $H . \times$ desetangsii and $H$. intermedium). Fröhlich (1911) described it as agreeing almost completely with the var. maculatum hybrids, but that (i) it was growing crowded together with both putative parents, so that cross-pollination was quite possible, (ii) it had characters intermediate between them, and (iii) its flowering dates were also intermediate. The latest of Fröhlich's collections of this hybrid (26 July 1914) was identified by him as $H$. maculatum subsp. styriacum $\times$ acutum.

1. Hypericum maculatum Crant $x \times 5$. H. perforatum L. (see $5 x$, p. 102).

2. Hypericum undulatum Schousb. ex Willd., Enum. pl. Berol.: 810 (1809); Spach in Ann. Sci. nat. Bot. 5: 357 (1836); Bab., Man. Brit. bot.: 67 (1843), in J. Bot. 2:: 97, t. 16 (1864); Archer Briggs in J. Bot. 2: 45 (1864); Hance in J. Bot. 5: 299 (1867); Nyman, Consp. fl. eur. 1: 133 (1878); Lange in Willk. \& Lange, Prodr. fl. hisp. 3: 591 (1878); Bonnet in Bull. Soc. Bot. France 25: 28 (1879); A. Fröhl. in Sitzungsber. Kaiserl Akad. Wiss., Math.Naturwiss. Kl. 120(1): 583 (1911); Ross-Craig, Draw. Br. Pl. 6: t. 10 (1952); N. Robson in Tutin et al., Fl. Europ. 2: 268 (1968); Franco, Nova Fl. Portugal 1: 453 (1971); A. Ramos in Trab. Dept. Bot. Univ. Complut. Madrid 12: 49 (1983), in Acta Bot. Malac. 11: 167, f. 6d (1986), in Castroviejo et al., Fl. Iberica 3: 167 (1989); Valdés, Talavera \& Galiano, Fl. Vasc. Andal. Occ. 1: 316 + map \& fig. (1987); B. Tebbs in Press \& Short, Fl. Madeira: 222 (1994); N. Robson in Cullen et al., Europ. Gdn Fl. 4: 60 (1995). Type: Morocco, Tangier, Schousboe s.n. (C-holotype; GBOISS!-isotype).

Fig. 7, Map 3.

H. quadrangulum var. [ع] undulatum (Schousb. ex Willd.) Choisy in DC., Prodr. 1: 548 (1824); Colm., Apunt. fl. Castillas: 37 (1849). 


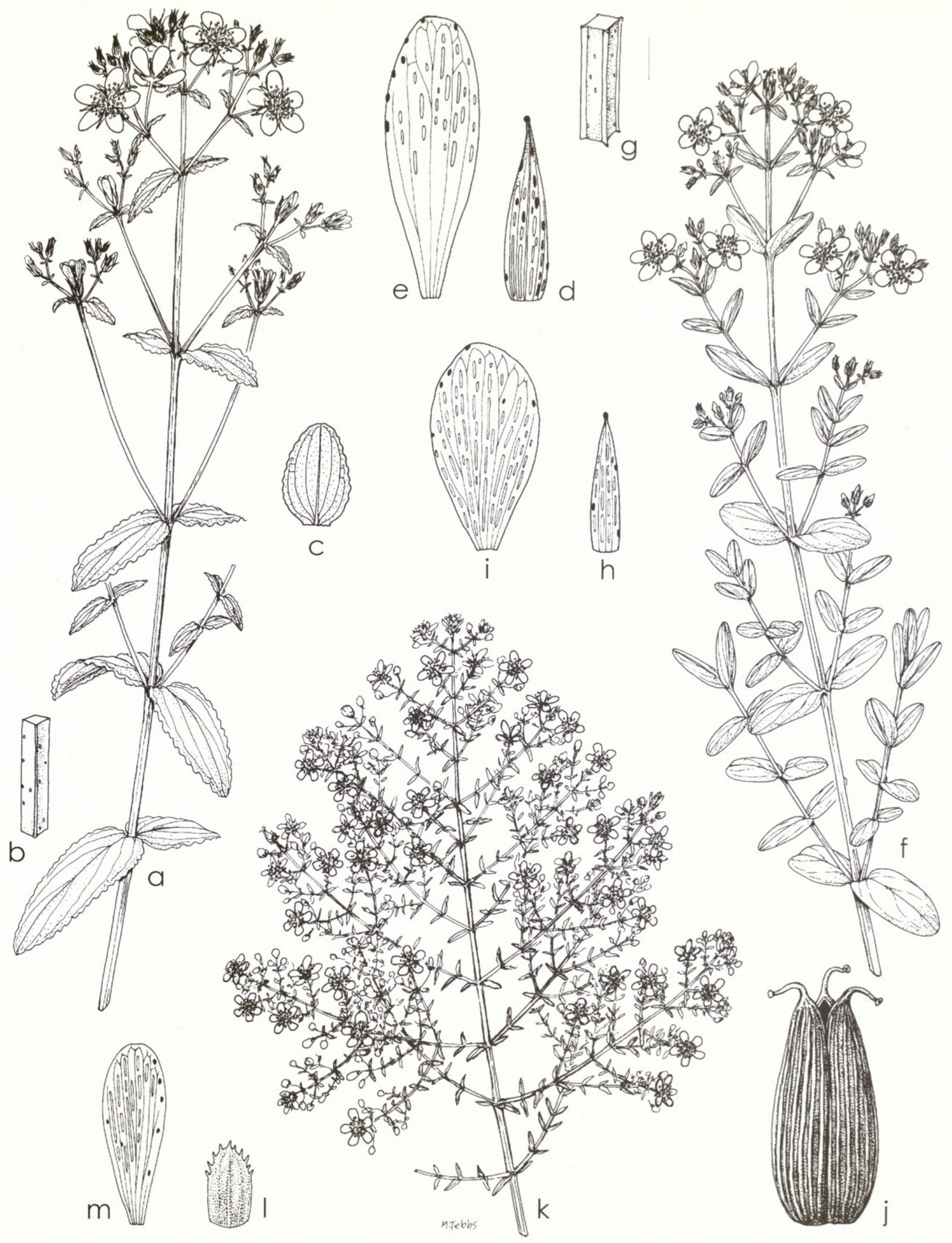

Fig. 7 A. H. undulatum var. undulatum: (a) habit; (b) stem section; (c) upper leaf; (d) sepal; (e) petal. B. H. tetrapterum var. tetrapterum: (f) habit; (g) stem section; (h) sepal; (i), petal; (j) capsule. C. H. triquetrifolium: (k) habit; (1) sepal; (m) petal (a, c, f, k $\times 2 / 3$; b, g $\times 2$; rest $\times 6$ ). A. (a, b) Goyder \& Jury 545; (c) Reverchon 238; (d, e) Davis 54961. B. (f, g) Gadeceau s.n.; (h, I) Granvik s.n.; (j) Coste 801. C. Davis \& Coode 39246. 
H. decipiens H. Watson in London J. Bot. 3: 588 (1844). Types: Azores, Flores (fl), $H$. Watson s.n. (K!-lectotype, selected here); Fayal (st), J.C. Hunt s.n. (K!-syntype).

H. quadrangulum sensu Colm., Recuerd. bot. Galicia: 10 (1850); Lowe, Man. fl. Madeira: 79 (1868) pro parte excl. typum.

H. boeticum sensu Syme, Engl. Bot., 3rd ed. 2: 153, t. 270bis (1864); H. Wats. in Godman, Nat. hist. Azores: 143 (1870); Bull in J. Bot. (Lond.) 13: 296 (1875); Trelease in Rep. Mo. bot. Gdn, no. 8: 100 (1897); Stefanoff in God. Agr.-les. Fak. Univ. Sofiya 10; t. 4 f. 27 (1932), 11: 176 (1933), 12: 88 (1934), in Pflanzenareale 4(1): Karte 6a (1933).

H. tetrapterum var. $[\beta]$ undulatum (Schousb. ex Willd.) Cout. in Bolm Soc. Brot. 12: 21-22 (1895), comb. illegit. (Art. 58.2).

H. acutum subsp. undulatum (Schousb. ex Willd.) Rouy in Rouy \& Foucaud, Fl. France 3: 337 (1896); Cout., Fl. Portugal: 404 (1913), 2nd ed.: 482 (1939); comb. illegit. (Art. 58.2).

$H$. desetangsii sensu Lloyd, Fl. Ouest France, 5th ed.: 72 (1898), non Lamotte (1874).

H. acutum var. undulatum (Schousb. ex Willd.) Pau in Bol. Soc. Aragonese Ci. Nat. 8: 118 (1909), comb. illegit. (Art. 58.2).

H. quadrangulum var. tetrapterum forma undulatum (Schousb. ex Willd.) Borg, Descr. fl. Malt. isl.: 248 (1927).

H. maculatum subsp. undulatum (Schousb. ex Willd.) P. Fourn., Quatre fl. France: 453 (1946).

H. tetrapterum subsp. undulatum (Schousb. ex Willd.) P. Silva in Agron. Lusit. 12(2): 271 (1951) comb. illegit. (Art. 58.2).

H. quadrangulum subsp. undulatum (Schousb. ex Willd.) Goday \& Carbonell in Anales Inst. Bot. Cavanilles 19: 380 (1961).

Icones: Bab. in J. Bot. (Lond.) 2: 97, t. 16 (1864); Ross-Craig, Draw. Br. Pl. 6: t. 10 (1952).

Perennial herb $0.015-0.12 \mathrm{~m}$ tall, erect to decumbent from creeping and rooting base, with stems numerous to few, initially unbranched below inflorescence, later branched above. Stems narrowly and \pm equally 4-winged, with black glands on the wings and sometimes elsewhere; internodes $12-65(-80) \mathrm{mm}$, longer than leaves. Leaves sessile; lamina 6-40 $\times(3-) 7-14(-20) \mathrm{mm}$, elliptic or narrowly ovate to narrowly oblong or rarely suborbicular, paler beneath, thickly to thinly chartaceous; apex rounded to obtuse or rarely subacute, margin usually crisped-undulate, base rounded to cordatesubamplexicaul; venation: 3(4) pairs of main laterals from lower quarter of midrib, tertiary reticulation rather dense; laminar glands pale, dense, medium to small; intramarginal glands black, close, irregular in size. Inflorescence 7-c. 40-flowered, from 1-3 nodes, with flowering branches ascending to horizontal from up to 6 nodes, the whole cylindric to subcorymbiform, lax; pedicels $1-2.5 \mathrm{~mm}$; bracts and bracteoles 2-4 mm long, lanceolate, entire, with (0-)2-8 black glands. Flowers $12-17 \mathrm{~mm}$ in diam., stellate; buds ellipsoid, obtuse. Sepals 5, subequal, 3-5.5 × 1-1.8 mm, narrowly elliptic to lanceolate, acute to acuminate, entire, erect in bud and fruit; veins (3)5-7, when 5 the outer pair branched; laminar glands punctiform, all pale or nearly always (3-)6-20(-28) black; intramarginal glands black, few or absent, rarely with terminal black gland. Petals 5, bright yellow, nearly always tinged red dorsally, (5-)7-10 × 3-4 $\mathrm{mm}, c .2-2.5 \times$ sepals, obovate-oblanceolate, entire; laminar glands black, punctiform, few or absent; marginal glands black, up to 6 , scattered, or absent. Stamens c. 25-40, '3'-fascicled, longest (4.5-) 5-8 mm, c. $0.75-0.9 \times$ petals. Ovary 3-locular, $2-3.5 \times 1-1.5 \mathrm{~mm}$, narrowly ovoid to narrowly ellipsoid; styles 3 , free, 3-4 mm, 1-1.3 $\times$ ovary, spreading; stigmas narrowly capitate. Capsule $5-8 \times 3.5-4$ $\mathrm{mm}$, c. $1.65 \times$ sepals, ovoid; valves with longitudinal linear vittae. Seeds yellow-brown, $0.6-0.8 \mathrm{~mm}$, cylindric, not carinate or appendiculate; testa linear-foveolate. $2 \mathrm{n}=16,32$ (ploidy apparently not correlated with morphology). The record of $2 n=8, n=4$ for this species by Guillén Oterino et al. (1997) is difficult to interpret. The count appears to be genuine, being vouched for and illustrated by drawings; but no other report of such a hypoploid number has been made elsewhere in the genus.

Non-calcareous marshes, mildly acidic bogs; 0-2700 m.

Extreme western Europe and North Africa: England (Cornwall, W. Devon), Wales (Pembroke, Cardigan, Merioneth), Ireland (W. Cork?, see below), France (W. Brittany, see below), central and W. Spain, Portugal, W. Algeria, N. Morocco, Madeira, Azores.

Hypericum undulatum occurs as two very unequal varieties. The vast majority of the species (var. undulatum) has relatively narrow undulate leaves and red-tinged flower buds; but a population in the south of Spain (Sierra Nevada) has broader plane-margined leaves and untinged flower buds. This population, which Boissier named Hypericum boeticum, appears to be intermediate in some characters between 2. H. undulatum and 3. H. tetrapterum; and since there are some plants with intermediate characters elsewhere in the Iberian Peninsula, some (particularly Spanish and Portuguese) botanists reduced these taxa to subspecies. The real 'link' between these species, however, would seem to be the plant from southern Italy and Sicily known as $H$. neapolitanum Ten., which is the most luxuriant form of $H$. tetrapterum. Hypericum boeticum, on the other hand, has flowers and inflorescence typical of $H$. undulatum in size and shape; and the broad leaves (which are linked in the population with ones more typical of $H$. undulatum) should be interpreted as a development in that species parallel with the broadening of the leaves in more advanced forms of $H$. tetrapterum. The plane margins and plain yellow petals are thus a reversion, not an intermediate condition. Populations that are truly intermediate between these species and apparently hybrid in origin occur in scattered localities in the Iberian Peninsula (see below). It seems appropriate, then, to treat the Sierra Nevada population as a variety (var. boeticum).

\section{2a. Hypericum undulatum var. undulatum}

Plant erect. Leaves (3-)4-14(-18) mm broad, elliptic to ovate, margin crisped-undulate. Petals red-tinged dorsally.

\section{$0-1750 \mathrm{~m}$.}

Distribution of the species except extreme south Spain. The record for Ireland (Co. Cork) is based on a specimen in $\mathrm{K}$ and that for France (Brittany) on specimens of a Lloyd collection in BM and ANG. The former, from Glengarriff, could just possibly be due to mislabelling, but the latter appears to be a correct record. Both collections were misidentified, the former as H.tetrapterum and the latter as $H . \times$ desetangsii. Lloyd, in Fl. Ouest France 5th ed., cites several localities round Brest for $H$. $\times$ desetangsii, his description of which agrees with $H$. undulatum, not $H . \times$ desetangsii. It seems, therefore, that the 'Atlantic' distribution of $H$. undulatum includes (or included) the extreme 'Atlantic' part of France and possibly SW Ireland.

WALES. Merioneth: Morfa Arthog (Arthog Bog), 2 August 1953 (fl), Benoit s.n. (K). Cardigan: 0.4 km W. of Trawscoed Station, 1933, Salter (Salter, 1935). Pembroke: between St. David's and Solva, 8 August 1931 (fl), Alston s.n. (BM); near Narberth, 1885 (fl), Barrett s.n. (BM).

ENGLAND. W. Cornwall: Penzance, Tremethick Moor, 7 August 1911 (fl), Barton s.n. (BM, K); N. of Camborne, Reskadinnick, 4 August 1971 (fl), Murphy s.n. (BM). E. Cornwall: Tywardreath Marsh, 23 July 1935 (fl), Grose 1278 (BM); near Falmouth, Penjerrick, August 1871 (e. fr), T.A. Briggs s.n. (BM). S. Devon: Morwellham, 9 August 1901 (fl), Hume 3944 (BM); Egg Buckland, Common Wood, 31 August 1872 (1. fl), T.A. Briggs s.n. (BM). N. Devon: Torrington, 9 September 1935 (fl \& fr), Chapple s.n. (BM). 


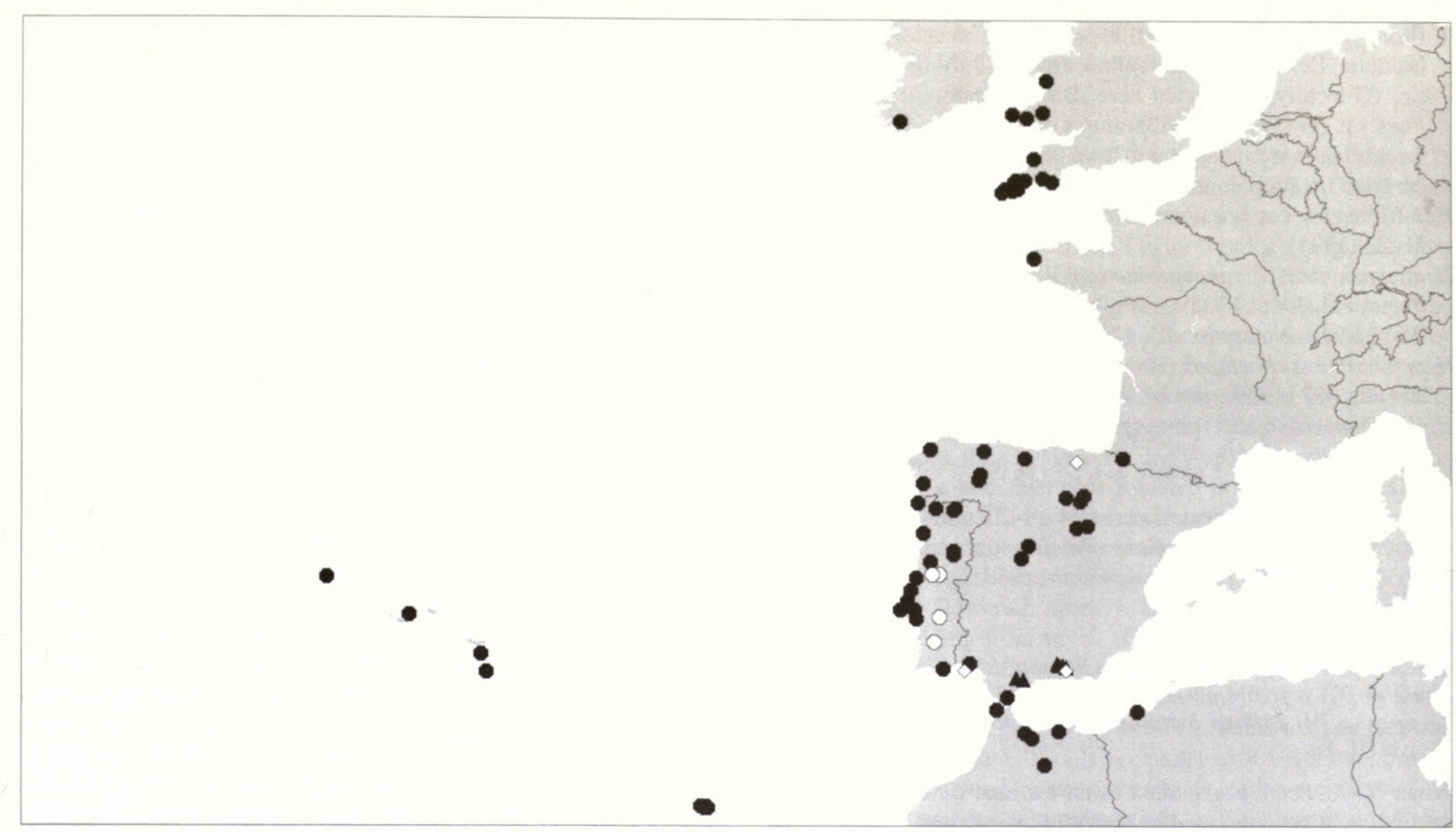

Map 3 2. H. undulatum. a. var. undulatum $\bullet$, other records O; b. var. boeticum $\boldsymbol{\Delta}$. 2. H. undulatum $\times 3$. H. tetrapterum $\diamond$.

IRELAND? W. Cork: Glengariff, 18 August 1908, C. Bucknall s.n. (K). See Robson (1958b); but this record is not mentioned by Perring (1996).

FRANCE. Finistère: environs de Brest, end July 1886 (fl), Blanchard in Lloyd s.n. (ANG, BM); cult. du jardin d'un pied de Brest, end July 1890 (fl), Lloyd s.n. (ANG).

SPAIN. Pontevedra: Pontevedra, 27 July 1930 (fl \& fr), Buch s.n. (H). Coruña: La Coruña, near Coruña, August 1888 (fl), Guardia s.n. (BM). Oviedo: gorge of Peña de la Paloma, near Tineo, 16 July 1927 (fl), Wilmott s.n. (BM). Cantabria: Santander, Picos de Europa, Fuente De, 1200 m, 1 August 1969 (fl), Grimes 229 (BM). Léon: El Bierzo, Villanueva to San Adrian, 900 m, 10 July 1933, Rothmaler 471 (JE). Soria: Vinuesa, Santa Inés, in loco Gargantillas, 1450 m, 15 July 1989 (fl), Segura Zubizarreta in Soc. Exch. Pl. Vasc. Eur. Bass. Med., Fasc. 23, 14273 (RNG). La Rioja: Valle del Río Iregna, between Pantano Ortigosa and Lumbreras, 1 July 1958 (bud), Sandwith 5265 (K). Avila: 25 km SE of Avila, 3 August 1962 (fl), Scott 359 (BM). Zaragoza: Catalayud, Sierra de Vicort, 23 July 1910 (fl), Viciosa in Sennen 1122 (FR, H, JE). Tarragona: Cambrils, acequia 'Canaleta del Civil', Partida de l'Ardiaca, 12 August 1926 (fl), Teodora s.n. (BM). Guadalajara: Aldeanueva de Atienza, 11 September 1965 (fl), Silvestre s.n. (RNG, SEV*). Huelva: between Palos de la Frontera and Punta Arenilla, 8 October 1968 (fl \& fr), Bramwell \& Valdés 173 (RNG).

PORTUGAL. Throughout, but rarer in SE (Franco, 1971: 453). Minho: Viana do Castelo, fl. Minii prope Seixas, 29 July 1938, Rothmaler s.n. (JE). Tras-os-Montes: Vila Real, Chaves, prope Sapiäes, 800 m, 31 July 1938, Rothmaler 14002 (JE). Douro Litoral: S. of Oporto, Granja, 31 July 1910 (fl), Johnston s.n. (BM). Beira IIta: Guarda, Serra da Estrêla, 5 km from Pousada de Säo Lourenço to Gouveıa, 1360 m, 20 August 1982 (fl), Goyder \& Jury 545 (BM, RNG). Beira Baixa: fide Ramos (1993). Beira Litoral: Coimbra, 20 September 1950 (e. fr), J.\&A. Matos s.n. (BM). Estremadura: Lisboa, Torres Vedras prope Puteiro, 3 July 1936, Rothmaler s.n. (JE). Ribatejo, Alta Alentejo, Baixa Alentejo: fide Ramos (1993). Algarve: Faro, ribeira de S. Cristoväo, August 1882 (e. fr), Peres in Fl. Lusit. ( $4^{0}$ anno) 562 (BM).

MOROCCO. Tanger: Tetuan, Cap Spartel, 200 m, 3 July 1989 (fl), Garcia, Silvestre \& Talavera 110/89 (SEV). Rif: W. side of Ketama, 15001600 m, 8 July 1973 (fl), Davis 54961 (BM, E*). Moyen Atlas: Ras Chedaya, Bab Bouidir, 1400 m, 2 August 1968 (fl), Fry 193 (BM).
ALGERIA. Oran: Gambetta, 9 June 1913 (fl), Faure s.n. (H).

MADEIRA. S. of Ribeiro Frio, 3 km N. of Poiso, 1100 m, 31 July 1979 (fl), Jarvis \& Wild 820 (MO); Queimadas, 900 m, 17 August 1961 (fl), Coleridge 6 (BM; K); Santa Madalena, 4 July 1957 (fl), Malmberg s.n. (H); Passa d'Area, 12 August 1855 (fl), Lowe s.n. (BM).

AZORES. Santa Maria: Ribeira da Vila, 50 m, 2 May 1972 (st), Gonçalves 3947 (BM). São Miguel: Seara near Sete Cidades, Lagoa Azul, W. bank, 243 m, 26 July 1970 (fl), Dolman 329 (BM). Terceira: Terreiro dos Prados, 450 m, 10 July 1971 (fl), Gonçalves 3148 (BM). São Jorge: Camolico do Pinheiro, 400 m, 4 September 1971 (e. fr), Gonçalves 3442 (BM). Pico: Madalena, 9 July 1938 (fl), Cederkreutz s.n. (H). Faial: Caldeira, 500 m, 7 October 1971 (fl \& e. fr), Gonçalves 3652 (BM). Flores: Fazenda, Santa Cruz to Lajes, 200 m, 3-8 September 1985 (fl), Parry 103 (BM). Corvo: Weather station, 200 m, 3 September 1967 (fl), Pryor 170 (BM).

2b. Hypericum undulatum var. $[\beta]$ boeticum (Boiss.) Lange in Willk. \& Lange, Prodr. fl. hisp.: 591 (1878); N. Robson in Tutin et al., Fl. europ. 2: 268 (1968) in adnot. Type as for H. boeticum Boiss.

Map 3.

H. boeticum Boiss., Elench. pl. nov.: 25 (1838), Voy. bot. Espagne 1: t. 34 (1839), 2: 114 (1839); Nyman, Consp. fl. eur. 1: 133 (1878); Burdet, Charpin \& Jacquem. in Candollea 39: 788 (1984). Types: Spain, Granada, prope Yunquera prov. Malacitanae, 1837, Boissier \& Reuter s.n. (G-BOISS!-lectotype, N. Robson, 22 June 1955); prope Alhaurin, Carratraca et thermas Viló, Boissier \& Reuter s.n. (G-BOISS!-syntype); secus fluvium Jenil inter Granada et Guejar, Boissier \& Reuter s.n. (G-BOISS!-syntype); inter Berja et Adra in ditione Alpujarras dicta, Boissier \& Reuter s.n. (G-BOISS!syntype). 'In humidis mont. Regn. Granat. vulg., Aest. 1837' (fl), Herb. Boissier (K) is likely to be a duplicate of one of the above collections.

H. tetrapterum var. [ $[\beta]$ rotundifolium Willk. in Willk. \& Lange, 
Prodr. fl. hisp. 3: 591 (1878). Type: Spain, Granada, Barranco de Gualnon, Dehesa de S. Geronimo, 1800 m, July 1844, Willkomm s.n. (G-lectotype, selected here; BM!-isolectotype); Monachil, Funk s.n. (G-syntype). Willkomm's original (unpublished) name for this taxon would appear to have been var. nivale, according to the label on Willkomm, Pl. Hisp. Exsicc.1844-6 no. 358 (BM).

H. tetrapterum var. boeticum (Boiss.) Cout. in Bolm Soc. Brot. 12: 21-22 (1895).

H. acutum var. $[\beta]$ rotundifolium (Willk.) Schinz in Bull. Herb. Boissier II, 3: 16 (1902); A. Fröhl. in Sitzungsber. Kaiserl. Akad. Wiss., Math.-Naturwiss. Kl. 120: 582 (1911), comb. illegit.

H. acutum subsp. boeticum (Boiss.) Cout., Fl. Portugal: 404 (1913), 2nd ed.: 482 (1939), comb. illegit.

H. baeticum sensu auct. plur., sphalm.

Icon: Boiss., Voy. bot. Espagne 1: t. 34 (1839).

Plant erect to decumbent. Leaves (4-)8-20 mm broad, broadly elliptic to orbicular, margin plane. Petals not red-tinged dorsally.

\section{$1500-2700 \mathrm{~m}$.}

Spain (Andalucia).

SPAIN. Granada: barranco del río Segura, 1500 m, July 1906 (e. fl), Reverchon 238 p.p. (BM, FR, H); Capileira, c. 1750 m, 18 June 1962 (st), Rovainen s.n. (H). Málaga: Sierra de Yunquera, 3 July 1890 (fl), Reverchon 238 p.p. (JE, K).

When $H$. boeticum is regarded as an extreme development of $H$. undulatum, it becomes evident that Willkomm's var. rotundifolium is not part of $H$. tetrapterum but forms an extreme development of $H$. undulatum var. boeticum. Indeed there seems to be no break in variation between typical var. boeticum and the higher-altitude 'var.' rotundifolium, which differs in its decumbent habit, smaller leaves and fewer smaller flowers. Examples of this form (additional to the syntypes cited above) are:

SPAIN. Granada: Sierra Nevada, pass between Borreguiles de San Juan and Peñones de San Francisco, 2700 m, 23 August 1948 (e. fr), Heywood \& Davis 983 (BM); Río Monachil, 2300 m, 28 July 1950 (fl), Rovainen s.n. (H).

\section{H. undulatum $\times 3$. H. tetrapterum \\ Map 3.}

The following specimen has characters intermediate between $2 \mathrm{a} . H$. undulatum var. undulatum and $4 \mathrm{a}$. H. tetrapterum var. tetrapterum and is assumed to be a hybrid between these taxa:

SPAIN. Viscaya: Bilbao mont., 20 July 1905 (fr), Elias 801 (BM).

An intermediate specimen from Andalucia, however, is probably a hybrid involving 2 b. H. undulatum var. boeticum:

SPAIN. Granada: Andalucia, near Trevelez, Puerta de Granada, $1260 \mathrm{~m}$, 4 August 1969 (fl), Brinton-Lee 940 (BM).

3. Hypericum tetrapterum Fr., Novit. fl. suec.: 94 (1823), ed. altera: 236 (1828); Spach, Hist. nat. vég., Phan. 5: 387 (1836), Ann. Sci. Nat. Bot. 5: 357 (1836); W. Koch, Syn. fl. germ.: 134 (1837); Rchb., Ic. fl. germ. helv. 6: t. 344, f. 5179 (1844); Godr. in Gren. \& Godr., Fl. France 1: 34 (1847); Bellynck, Fl. Namur: 31 (1855); Syme, Engl. Bot. 3rd ed. 2: 152, t. 270 (1864); Boissier, Fl. orient. 1: 805 (1867); Bab., Man. Brit. bot., 6th ed.: 66 (1867); Lange in Willk. \& Lange, Prodr. fl. hisp. 3: 591 (1878); Bonnet in Bull. Soc. Bot. France 25: 279 (1879); Schinz \& Keller, Fl. Schweiz: 326 (1900); Coste, Fl. France 1: 259 (1901); Stefanoff in God. Agr.-les. Fak. Univ. Sofiya 10: t. 4 f. 26 (1932), 11: 175 (1933), 12: 87 (1934), in Pflanzenareale 4(1): Karte 6a (1933); Mansfeld in Repert. Spec. Nov. Regni Veg. 47: 278 (1939); Pugsley in J. Bot. 78: 35 (1940); Ross-Craig, Draw.
Br. Pl. 6: t. 9 (1952); N. Robson in Davis, Fl. Turkey 2: 399 (1967), in Tutin et al., Fl. Europ. 2: 268 (1968), in Rech.f., Fl. Iranica, Guttif.: 17 (1968), in Townsend \& Guest, Fl. Iraq 4: 378 (1980); in Cullen et al., Europ. Gdn Fl. 4: 60 (1995), in Wisskirchen \& Haeupler, Standardliste Farn- u. Blütenpfl. Deutschl.: 270 (1998); Pignatti, Fl. Italia 1: 177 (1982); Zelený et al. in Futák \& Bertová, Fl. Slovenska 3: 306, t. 37 f. 2, map 57 (1982); Hagemann in Flora 173: 115, tt. 5B, 15-18, 39 (1983); A. Ramos in Trab. Dept. Bot. Univ. Complut. Madrid 12: 49 (1983), in Acta Bot. Malac. 11: 167, t. 6c (1986), in Castroviejo et al., Fl. Iberica 3: 168, t. 46 (1989); Azadi in Fl. Iran 27: $9+$ t. + map (1999). Type: Sweden, Skåne, in silva Resten, 1819 (?), Fries s.n. (UPS-holotype).

Fig. 7, Map 4.

H. quadrangulum L., Sp. pl.: 785 (1753); Huds., Fl. angl.: 292 (1762); Crantz, Stirp. austr. 2: 65 (1763); Leers, Fl. herborn., 2nd ed.: 169 (1789); Vill., Hist. pl. Dauphiné 3: 497 (1789); Sm., Engl. Bot.: t. 370 (1797), Fl. Brit. 2: 801 (1800); DC., Fl. France 4: 862 (1805); Choisy, Prodr. monogr. fam. Hypéric.: 47 (1821), in DC., Prodr. 1: 548 (1824); Bab. in Trans. bot. Soc. Edinburgh 1: 83 (1841), Man. Brit. bot.: 57 (1843); Syme, Engl. Bot., 3rd ed. 2: 152, t. 270 (1864); Rendle \& Britten in J. Bot. 45: 436 (1907); Grande in Boll. Orto bot. Regia Univ. Napoli 8: 74 (1926); Pugsley in J. Bot. 78: 25 (1940); N. Robson in Greuter, Burdet \& Long, Med-Checklist 3: 271 (1986); nom. rejic. (see N. Robson in Taxon 39: 135 (1990) and Brummitt in Taxon 43: 114 (1994)). Type: Netherlands (?), Hort. Cliff. 380 (BM!-holotype).

H. quadrangulare sensu L., Diss. Hypericum: 5 (1776), Amoen. Acad. 8: 322 (1785); Murray, Syst. veg., 14th ed.: 584 (1784); Lam., Dict. 4: 163 (1797); Willd., Sp. pl. 3: 1459 (1802), sphalm. Type as for $H$. quadrangulum $\mathrm{L}$.

H. acutum Moench, Methodus: 128 (1794); Beck, Fl. NiederÖsterreich 2(1): 530 (1892); Rouy in Rouy \& Fouc., Fl. France 3: 335 (1896); Burnat, Fl. Alpes marit. 2: 28 (1896); Schinz in Bull. Herb. Boissier II, 3: 16 (1902), in Vierteljahrsschr. Naturf. Ges. Zürich 49: 241 (1905); A. Fröhl. in Sitzungsber. Kaiserl. Akad. Wiss., Math.-Naturwiss. Kl. 120(1): 580 (1911); Thellung in Allg. Bot. Z. Syst. 1912: 19 (1912); Coutinho, Fl. Portugal: 404 (1913), 2nd ed.: 481 (1939); R. Keller in Engl. \& Prantl, Nat. Pflanzenfam. 2nd ed. 21: 179 (1925); Hegi, Ill. Fl. Mitt.-Eur. 5(1): 520 (1925); Briquet, Prodr. fl. corse 2(2): 144 (1936); Gorschkova in Shishkin \& Bobrov, Fl. URSS 15: 241 (1949); Stjep.-Vesel. in Josifović, Fl. Srbije 3: 116, t. 33 f. 2 (1972); nom. illegit. (Art. 52). Type as for $H$. quadrangulare $\mathrm{L}$.

[H. alatum Retz., Obs. bot.: 18 (1810); Rchb. in Flora 5: 530 (1822). Type: ex America septentrionale, Collector? (LU). Wahlenberg (Fl. suec.: 476 (1826)) makes this a synonym of his $H$. quadrialatum along with ' $H$. quadrangulare Sm.' and $H$. tetrapterum $\mathrm{Fr}$.; but the original description (e.g. ... caule ... subtomentoso, calycibus serrulato-glandulosis) clearly applies to quite another plant.]

H. quadratum Stokes, Bot. Mat. Med. 4: 99 (1812), nom. illegit. (Art. 52). Type as for H. quadrangulum $\mathrm{L}$.

H. quadrangulum var. [ठ] sensu Choisy, Prodr. monogr. Hypéric.: 47 (1821).

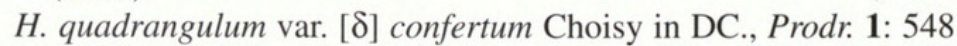
(1824). Type unlocalized, collector unrecorded (G-DC!-lectotype, selected here); England, 1816, Dawson Turner s.n. (G-DC!-syntype). Although Choisy cites only 'Anglia' for the provenance of his var. $\delta$ in 1821 , the Dawson Turner specimen is $H$. perforatum. The other specimen, however, is $H$. tetrapterum, and its dense inflorescence would appear to be the origin of the epithet confertum. 
H. quadrangulare var. $[\alpha]$ humile Boenn., Prodr. fl. monast. westphal.: 227 (1824). Type: Germany, none stated.

H. quadrangulare var. [ $\beta]$ alatum (Retz.) Boenn., Prodr. fl. monast. westphal.: 227 (1824) pro parte excl. typum. See H. alatum Retz. above.

H. quadrangulare var. $[\gamma]$ patulum Boenn., Prodr. fl. monast. westphal.: 227 (1824). Type: Germany, none stated.

H. quadrialatum Wahlenb., Fl. suec.: 276 (1826), nom. illegit. (Art. 52.1). Type as for H. tetrapterum.

H. neapolitanum Ten., Ind. Sem. Hort. Neap. ann. 1829: 19 (1829); Guss., Fl. sic. syn. 2: 379 (1843); Lojacono-Pojero, Fl. sicula 1(1): 188 (1886-88). Type: Sicily, sine loc., in pratis paludosis, pre May 1830 (fl), Tenore s.n. (NAP-holotype; K!-isotype). Gussone gives a valid description but attributes the name to Tenore. I have not been able to check that Tenore himself provided a valid description.

H. confertum (Choisy) G. Don, Gen. Syst. 1: 606 (1831), non Moench (1794) nec Choisy (1821), nom. illegit. (Art. 52). Based on $H$. quadrangulum var. confertum Choisy.

H. neapolitanum var. confertum (Choisy) Guss., Fl. sic. syn. 2: 379 (1843); Lojacono-Pojero, Fl. sicula 1: 188 (1886-1888). Type as for $H$. quadrangulum var. confertum Choisy.

Holosepalum quadrangulum (L.) Fourr. in Ann Soc. Linn. Lyon, N.S. 16: 352 (1868).

Hypericum rotundatum Schur in Verh. naturf. Vereins Brünn 15(2): 159 (1877). Type: Romania, Transylvania, 'Auf Moorwiesen, an Gräben auf den Burgenwiesen bei Kronstadt [Braşov]', July 1854, Schur s.n. (FR!-holotype).

H. borbasii Formánek in Verh. naturf. Vereins Brünn 29: 143 (1891). Type: Turkey: Istanbul (Asia), Alemdağ ('Alemda'), July-August 1890 (fl), Formánek s.n. (BRNM!-holotype).

H. quadrangulum var. acutum (Moench) Fiori in Fiori \& Paol., Fl. Italia 1: 387 (1898), Nuovo fl. Italia 1: 521 (1924), comb. illegit. (Art. 58.2).

H. quadrangulum subsp. quadrangulum sensu Tourlet in Bull. Soc. Bot. France 50: 307 (1903); Schinz in Vierteljahrsschr. Naturf. Ges. Zürich 49: 231-241 (1905), pro parte uterque quoad typum.

H. tetrapterum forma stigmaphyllum Woron. in Kuzn., Busch \& Fomin, Fl. Cauc. crit. 3(9): 43 (1906). Type: Russia, Ciscaucasia, Stavropol, Norman s.n. (LE).

H. tetrapterum var. [b] neapolitanum (Ten.) N. Terracc. in Nuovo Giorn. Bot. Ital. 14: 135 (1907).

H. acutum forma humile (Boenn.) Hegi, Ill. Fl. Mitt.-Eur. 5(1): 521 (1925); Guşul. in Săvul., Fl. R. P. Roman. 4: 26 (1956) ['Boenningh. ex Hegi'].

H. acutum forma patulum (Boenn.) Hegi, Ill. Fl. Mitt.-Eur. 5(1): 521 (1925).

H. acutum subsp. eu-acutum Hayek, Prodr. Fl. Pen. balc. 1: 534 (1925), nom. illegit. (Arts 21.3, 52, 58.2).

H. maculatum subsp. quadrangulum (L.) Hayek, Prodr. Fl. Pen. balc. 1: 534 (1925), pro parte quoad typum.

H. quadrangulum var. tetrapterum (Fr.) Borg, Descr. Fl. Malt. isl.: 248 (1927).

H. acutum subsp. tetrapterum (Fr.) Maire in Jahandiez \& Maire, Cat. pl. Maroc: 483 (1932), comb. illegit. (Art. 58.2).

H. acutum var. typicum Guşul. in Săvul., Fl. R. P. Roman. 4: 885 (1956). Type as for $H$. acutum Moench=H. quadrangulum L. $=H$. tetrapterum Fr. On p. 26 this combination is given as 'f. nova', but on p. 885 (with other nomenclatural novelties) as 'var. nova'. The latter would seem to have been intended.

H. quadrangulum subsp. acutum (Moench) Goday \& Carbonell in Anales Inst. Bot. Cavanilles 19: 380 (1961), comb. illegit. (Art. 58.2).
H. fallax subsp. fallax var. quadrangulare (L.) O. Schwarz in Drudea 5: 63 (1965) pro parte quoad typum.

Icones: see under varieties.

Perennial herb (0.15-)0.2-0.7(-1.2) $\mathrm{m}$ tall, erect to \pm decumbent or rarely ascending to procumbent from creeping and rooting base, with stems numerous to few, initially unbranched below inflorescence, later branched above for half to most of their length. Stems \pm broadly 4-winged, the subsidiary wings narrower or rarely with wings equally narrow, with black glands on the lines and sometimes elsewhere; internodes 7-50 $\mathrm{mm}$, shorter than to exceeding leaves. Leaves sessile or rarely (especially the lower) up to $0.5 \mathrm{~mm}$ petiolate; lamina (6-)9-40 × (4-)7-24 mm, ovate or elliptic or triangular-ovate to orbicular, somewhat paler beneath, thinly chartaceous; apex rounded to very rarely apiculate-obtuse, margin plane or rarely \pm undulate, base rounded to cordate-amplexicaul; venation: 1-3 pairs of main laterals from base of midrib; tertiary reticulation dense, rather obscure; laminar glands pale, dense, small; intramarginal glands black, rather close, uniform. Inflorescence (1-) 10-35(-c. 70)-flowered, from 1-2(-4) nodes, with flowering branches ascending from up to 10 nodes, the whole cylindric to corymbiform, dense or with partial inflorescences dense; pedicels 1-2 $\mathrm{mm}$; bracts and bracteoles 2-3 mm long, lanceolate to linear, entire, with $0-4$ black glands. Flowers $10-15 \mathrm{~mm}$ in diam., stellate; buds ellipsoid, subacute. Sepals 5, equal, 3-5 × 1-1.5 mm, lanceolate to narrowly oblong, acute to acuminate, entire, erect in bud and fruit; veins 3 with outer pair branched or 5 unbranched; laminar glands striiform to punctiform or occasionally basal linear, all pale or 1-2 black; marginal glands absent or rarely up to 7 , black, immersed. Petals 5, rather pale yellow, not tinged red, 5-8 $\times 2-3(-$ 4) $\mathrm{mm}, c .1 .4 \times$ sepals, oblanceolate, entire or distally unilaterally crenate; laminar glands absent or rarely few, punctiform, black and pale; marginal glands $1-4$ or usually absent. Stamens $30-40(-60)$, '3'-fascicled, longest c. 4.5-7.5 mm, c. $0.9 \times$ petals. Ovary 3locular, 2-2.5 $\times 1-1.5 \mathrm{~mm}$, narrowly ovoid; styles 3 , free, $2-3.5 \mathrm{~mm}$, $0.8-1.4 \times$ ovary, widely spreading. Capsule $5-7(-8) \times 2.4-4 \mathrm{~mm}, c$. $2 \times$ sepals, narrowly cylindrical-ellipsoid to ovoid; valves with longitudinal linear vittae. Seeds dark brown, 0.6-0.8(-1.1) mm, cylindric, not carinate or appendiculate; testa finely foveolate. $2 \mathrm{n}=16$ (Stenar, 1938; Noack, 1939; Pólya, 1950; Robson, 1956; Gadella \& Kliphuis, 1966; Zhukova, 1967), n=8 (Nielsen, 1924; Winge, 1925; Chattaway, 1926; Noack, 1939; Sugiura, 1944).

In wet habitats - marshes, streamsides, open ditches, wet meadows, springs; 0-1300 m (Switzerland, Valais), -1900 m (Corsica), -2000 m (Turkey).

Europe from Scotland (Orkney and Sutherland southward), Denmark, S. Sweden (Skåne), Poland, the SW Ukraine and Transcaucasia south to Spain, Algeria, Sicily, Greece, Turkey, N. Israel, N. Iraq and NW Iran.

The variation in $H$. tetrapterum is wide but almost continuous, from a tall, branching, relatively narrow-leaved form in southern Italy and Sicily ('H. neapolitanum') to short unbranched forms in northern Europe. In two areas, however, decumbent small-leaved few-flowered high-altitude forms have developed - Corsica and the Levant. Although in neither area have field studies been made to decide how distinct these forms are from the adjacent typical form, they both seem worth recognizing at least until such studies are made.

Hypericum tetrapterum is related to $2 \mathrm{~b}$. H. undulatum var. undulatum, differing from it in the more broadly winged stem internodes, the usually relatively broader leaves with plane margin, 
and the denser inflorescence with smaller flowers, sepals with fewer black laminar glands, and paler petals that are not tinged red. The form most similar to var. undulatum occurs in southern Italy and Sicily ('H. neopolitanum Ten.').

\section{3a. Hypericum tetrapterum var. tetrapterum}

H. tetrapterum subsp. tetrapterum, Zangheri, Fl. Ital.1: 396 (1976).

Icones: Rchb., Ic. fl. germ. helv. 6: t. 344, f. 5179 (1844); RossCraig, Draw. Br. Pl. 6: t. 9 (1952); Ramos in Castroviejo et al., Fl. Iberica 3: t. 46 (1989).

Stems erect, to $1.2 \mathrm{~m}$ tall. Leaves sessile or lowermost to $0.5 \mathrm{~mm}$ petiolate, 9-40 mm long, ovate or elliptic to orbicular, margin nearly always plane. Inflorescence 10-c. 70-flowered, from 1-4 nodes, with flowering branches from up to 10 nodes below.

Lowland to montane zones; 0-1380 m.

Distribution as for species, except for the alpine zone (1380-2000 m). SCOTLAND. Orkney: Hoy, North Walls, Lyness, 16 July 1956 (fl), Sinclair 8872 (K). East Ross: Dingwall, 25 July 1961 (fl), McCallum Webster 5788 (K). Moray: near Elgin, Lochinver Farm, 13 August 1960 (fr), McCallum Wester $3833(\mathrm{~K})$. Kincardine: St. Cyrus, 6 August 1881, Nicholson s.n. (JE). Mid Perth: Crieff, near Comrie, July 1880 (fl) Bennett s.n. (BM). W. Lothian: near Kirkliston, 1 August 1905 (fl), Bennett s.n. (BM). E. Lothian: Aberlady, 15 August 1933 (fl \& fr), Taylor s.n. (BM). Lanark: Carluke, meeting of Cauldron Gill and Yieldshiel Burn, 11-15 July 1962 (fl), Phillips 176 (BM). Wigtown: Wigton, July 1895 (fl), McAndrew s.n. (BM). Clyde Isles: Arran, Whiting Bay, Glenashdale, 26 July 1953 (fl), Robson 24 (BM). Argyll: near Crarae, 20 July 1936 (fl), A.B. Jackson s.n. (BM). S. Ebudes: Islay, Bowmore to Laggan Bridge, 28 August 1955 (e. fr), Hillcoat s.n. (BM).

ENGLAND. Westmorland: Arnside, 5 August 1896 (fr), Worsdell s.n.
(K). Durham: Wynch Bridge, 18 June 1934 (fl), Taylor s.n. (BM). NE Yorks.: near Scarborough, Trontedale, 20 July 1939 (fl), Evans s.n. (BM). S. Lancs.: Freshfield Dunes, 26 July 1929 (fl), Holder 461 (LIV). Notts.: E. of Blaxton on B 1396, 25 July 1963 (fl), Bowden \& Hillman 359 (BM). S. Lincs.: near Fenhouses, 31 July 1945 (fl), N.D. Simpson s.n. (BM). Worcs.: Wyre Forest, 11 August 1915 (fl), Rea s.n. (BM). E. Gloucs.: Shuthanger Common, 22 September 1973 (fl), Fowler s.n. (BM). Huntingdon: Eynesbury, August 1944 (fl), Peck s.n. (BM). W. Suffolk: Mildenhall, July 1908 (fl), Adamson s.n. (BM). Oxford: King's Sutton, 1 August 1961 (fl), Sheasby 601 (BM). Middlesex: Finchley Common, 12 September 1925 (fr), Moring 282 (BM). Surrey: Horley, Langshott Wood, July 1948? (fl), Morgan s.n. (BM). E. Sussex: Pett, 12 September 1938 ( $\mathrm{fl} \& \mathrm{fr}$ ), Bangerter s.n. (BM). Isle of Wight: Freshwater, 1 August 1953 (fl), Hancock s.n. (BM). S. Wilts.: Donhead St. Mary, Alec's Shade, 4 August 1947 (fl), Wilmott 1102 (BM). N. Devon: Braunton Burrows, 15 July 1957 (fl), Matthews s.n. (BM). W. Cornwall: St. Ives, 17 June 1952 (fl), Edwards 57 (BM).

WALES. Glamorgan: Kenfig Dunes, 15 July 1934 (fl), N.D. Simpson s.n. (BM). Carmarthen: Pembrey, September 1900 (fl), Riddelsdell s.n. (BM). Pembroke: Sagerton Common, 18 August 1957 (fr), Powers 5 (BM). Radnor: near Rhos-goch, 18 August 1885 (fl), A. Ley s.n. (BM). Caernarvon: Bardsey I., August 1933? (fl), Butler (BM). Flint: Bodlewyddan Park, 12 August 1941 (fl), A.B. Jackson s.n. (BM).

IRELAND. N. Kerry: Lough Leane, E. side of Ross I., c. 20 m, 20 July 1973 Jermy 10391 (BM). W. Cork: near Toormore Mizen Head, near Ballyrigode House, 1 July 1961 (fl), James 60 (BM). Waterford: c. 2.4 km S. of Tramore, near road to Great Newton Head, 18 August 1967 (fl), Ferguson 2039 (BM). Dublin: How the Hill, August 1877 (e. fr), Gamble 26303 (K). Longford: $8 \mathrm{~km} \mathrm{SW}$ of Granard, 17 August 1961 (fl), Summerhayes 3599 (K). S. Donegal: Ballyshannon, 1992 (fl \& fr), Wyse Jackson s.n. (Herb. M.W.J.).

CHANNEL ISLANDS. Guernsey: Petit Bot Bay, 22 July 1950 (fl), $F$. Balfour-Browne s.n. (BM). Sark: near harbour, 10 July 1953, Sowerby 134 (BM). Herm: N. of island, 13 August 1952 (fl), Hancock s.n. (BM). Alderney: Clanque Bay, 16 August 1932 (fl), A.B. Jackson 579 (K). Jersey: no loc., 21 July 1900 (fl), Lester-Garland s.n. (K).

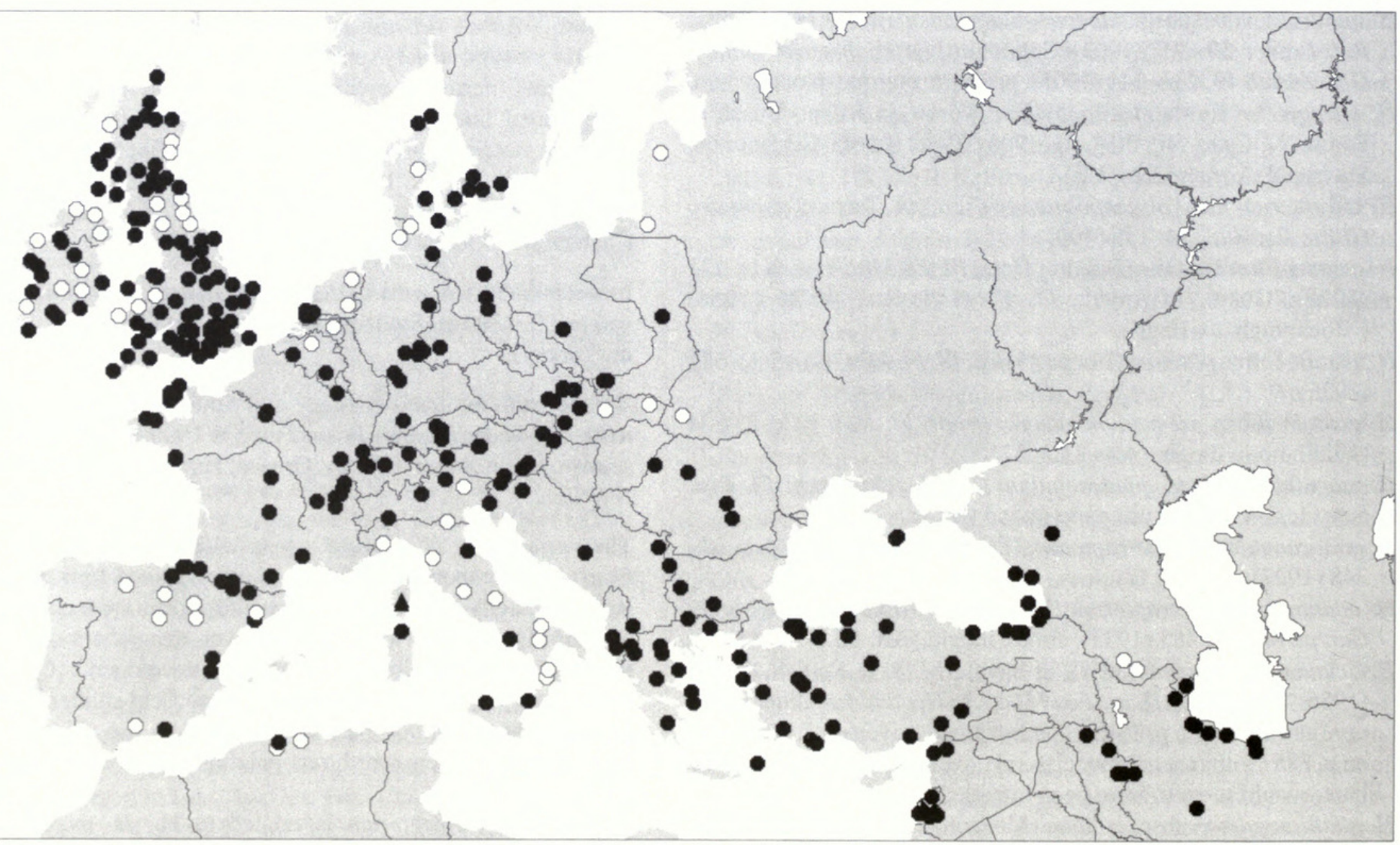

Map 4 3. H. tetrapterum. a. var. tetrapterum $\bullet$, other records $\bigcirc$; b. var. corsicum $\boldsymbol{\Lambda}$; c. var. anagallidifolium $\mathbf{\square}$ (among the Lebanon records). 
THE NETHERLANDS. Zuid-Holland: Rozenburg I., 'De Beer', 26 August 1948 (e. fr), Maas Geesteranus 4321 (K, L*). Utrecht: N. of Utrecht, Molenpolder, 19 August 1953 (fr), Leeuwenberg s.n. (H).

BELGIUM. Antwerpen: entre Lierre [Lier] et Emblehem, 25 July 1920 (e. fr), Lambert s.n. (BM). Namur: Wavreville, June 1914 (fl), Boulenger s.n. (BM).

FRANCE Oise: près Senlis, Fôret de Hallare, 18 August 1834 (fl), Bentham s.n. (K). Seine: bois de Meudon, 26 August 1889 ( $\mathrm{fl} \& \mathrm{fr}$ ), Gadeceau s.n. (BM). Finisterre: Morlaix, August 1883 (fl), Miciol s.n. (BM). Loire-Atlantique: ruisseau d'Escoublac, 1887 (fr), Gadeceau s.n. (BM). Deux-Sèvres: Saint-Genard, près de Chancelles, August 1951 (fl), Contre in Soc. Fr. Exch. Pl. Vasc. B. de Retz 5 (K). Cher: Saulzait-le-Potier, 22 July 1859 (e. fr), Déséglise s.n. (BM). Haut-Rhin: Pfetterhausen, 9 August 1869 (fl \& fr), Gadeceau 217ter (BM). Doubs: Besançon, marais de la Malcombe, n.d. (fl), Grenier 2036bis (BM, JE). Ain: Cascade de Glossdieu, 9 August 1891 (fl). Borel s.n. (K). Rhône: ad Ainas, 6 August 1874 (e. fr), Gandoger 407 (BM, K). Savoie: Saint Bezon, 7 August 1892 (fl), Borel s.n. (K). Puy-de-Dôme: Puy St Gulunier?, 7 August 1928 (fl), Eluss? 355 (BM). Cantal: Ydes, 8 August 1874 (fr), Héribaud-Joseph s.n. (BM). Aveyron: Saint-Paul-des-Forêts, August 1904 (fr), Coste s.n. (BM). Basses-Pyrenées: Harambetz, vid Chapelle St Nicolas, 15 August 1968 (fl), Sonck s.n. (H).

SPAIN. Guipuzcoa: Vascongadas, San Sebastián, M. Castelli, 80 m, September 1940, Rothmaler 16415 (JE). Huesca: Castejon de Sos, valley of Río Esera, c. 950 m, 27 July 1955 (fl), Sandwith s.n. (K). Barcelona: Montserrat, 24 August 1941 (fl \& e. fr), Collector? (RNG). Zaragoza: Catalayud, 17 July 1912 (fl), Vicioso s.n. (BM). Avila: Sierra de Gredos, Río Alberche S. of St. Martin del Pimpollar, c. 1450 m, 23 July 1974 (fl), Brenan 13036 (K). Castellón: Segorbe, 18 July 1922 (fl), Pau in Sennen Pl. Esp. 4620 (BM, RNG). Almería: Laujar de Andarax, 8 August 1978 (fl), Roivainen s.n. (H, RNG).

ALGERIA. Atlas Tellien: Médéa, gorges de la Chiffa ((fide Quézel \& Santa, 1963: 682); près Blidah [Blida], Ravin de l' Oued-el-Kebir, 13 July 1854 (fl), Cosson s.n. (G-BOISS). Petite Kabylie: Djudjura (fide Quézel \& Santa, 1963: 682).

CORSICA. Stagno di Palo, 20 July 1933 (fl), Aellen 1655 (K).

SARDINIA. Tempio, 7 August 1882, Reverchon s.n. (JE).

SICILY. Messina: Messina, Haeckel s.n. (JE). Collector? : [Boscovi Penzzubaltone della] Castagnera, July 1879 (fr), Tacono s.n. (FR). Palermo: Palermo, June 1900 (fl \& fr), Ross s.n. (BM).

ITALY. Venezia Giulia: bei Trieste, Monfalcone, September 1921 (fr), Meebold s.n. (K). Trentino-Alto Adige: Bozen [Bolzano], pre 1877 (fl), Hausmann 1377 (BM). Piemonte: Casale Masferrato, 15 July 1957 (fl), Ulla \& Cedercreutz s.n. (H). Massa-Carrara: Massa, August 1952, Pellegrini s.n. (H). San Marino: Carrepa, 7 September 1920 (e. fr), Pampanini s.n. (K). Campania: between Majori [Maiori] and Capo d'Orso, 29 June 1883 (fl), Lacaita 6400 (BM).

SWITZERLAND. Genève: Geneva, July 1859, Huet de Pavillon s.n. (JE). Vaud: Nyon ad pagum Trilia, 9 August 1876 (fl), Elfving s.n. (H). Bern: Radelfingen, 1 August 1879 (fl), de Rutte s.n. (K). Luzern: Lucerne, Sonnenberg, 24 July 1930 (fl), Rathbone s.n. (BM). Appenzell: am Gäbris ob Gais, July-August, Schneider s.n. (BM).

AUSTRIA. Tirol: Oberinntal, Vols bei Innsbruck, c. $600 \mathrm{~m}, 8$ August 1980 (fl), Polatschek s.n. (BM). Salzburg: near Salzburg, Gaisberg, n.d. (e. fr), Hinterhuber s.n. (K). Kärnten: Klagenfurt, 1864 (fl), Kokeil s.n. (K). Steiermark: Lemsitz, Rösegg Ettendorf bei Stainz, 14 August 1924 (fl \& fr), Troyer s.n. (H). Oberösterreich: bei Aishersheim, August 1861, Keck s.n. (JE). Niederösterreich: Mödling, Vorderbrühl, August 1919 (fr), Fenz? 82 (K). Burgenland: Podersdorf, Zitzmandorfer Wiesen, 1-9 August 1966 (fl), Excurs. Bot. Inst. Ffm. s.n. (FR).

GERMANY. Baden: Baierthab, 18 August 1883 (fl), Druce s.n. (BM). Württemberg: Oberamt Reutlingen, Kirchentellinsfurt, 31 July 1991?, Lindberg s.n. (H). Bayern: Oberbayern, Haspelmoor, 17 July 1918? (fl), Oberneder 3261 (BM). Hessen: Bickenbach, bei Darmstadt, 10 September 1961 (fl \& fr), Schaarschmidt 96 (FR). Thüringen: Souder bei Schlobheim, 25 July 1952 (fl), Launert s.n. (BM). Brandenburg: Lychen, bei Küstmichener Bach, 20 July 1900 (fl), Heiland s.n. (H). Schleswig-Holstein: Kaltenhöfer, 25 July 1893 (fl), Simmons s.n. (H).

DENMARK. Jutland: between Lönstrup and Hirtshals, 17 July 1967 (fl), Holm-Nielsen \& Jeppesen in Fl. Jutl. Exs. 347 (BM, H, TAI); Fünen: Potenden to Söndersö, 6 August 1883 (fl), Mortensen s.n. (H). Falster:
Hannenov Skov, D. 37, 17 July 1942 (fl), Dahl s.n. (BM). Zealand: W. of Vrangeskov, N. of Ringsted, 24 July 1969 (fl), Jacobsen \& Svendsen in Pl. Dan. Exs. $93(\mathrm{H})$.

SWEDEN. Skåne: Benstadt, 2 October 1899 (fr), Sjöshol s.n. (H); Par. Everöd, Lyngby, 31 August 1933 (fl), Hasslow s.n. (BM).

POLAND. Siedlce: Sedletz, ad pag. Jagodne prope urbem Łuków, 28 July 1902 (fl), Puring 1971 (H). Wrocław: Stawno apud Milicz, ad ripam stagni 'Golica', 5 August 1963 (fl), Kotowicz \& Koziol 857 (H). Bielsko-Biala: Wadowice, prope Andrychów, 6 August 1938 (fl), Łańcucka Pl. Polon. Exs. 330 (BM, JE).

UKRAINE. West and south-west regions (fide Karnaukh, 1955: 307); Krym: Oreanda, 29 July 1987 (fl), Golde s.n. (LE).

CZECH REPUBLIC. Moravia: bei Schnobolin n. Olmütz, June 1908 (fl), Laus s.n. (BM, JE, K); Brno, Bilovice, ad Ricmanice, c. 230 m, 27 July 1925 (1. fl), Mrkos 243a (H, K).

SLOVAKIA. Throughout (see Zelený et al., 1982: map 57).

ROMANIA. Transylvania: Cluj, ad pagum Feleac super oppidum Cluj, c. 650 m, 28 July 1923 (fl \& fr), Gürtler \& Nyárády 1521b (H); Oreada, inter oppida Bucea et Grossi, 900 m, 30 July 1971 (fl), Černoch 22232 (BM, H). Walachia: Muntenia, distr. Prahova, Prahova rly stn, 5 August 1923 (fl \& fr), Grintescu 1521a(H). Also in Moldavia (fide Guşuleac \& Nyárády, 1956: 26).

BULGARIA. Sofia: prope Sofia, ad radicem m. Vitoša [Cherni Vrŭkh], 5 August 1939 (fl), Lindberg s.n. (H).

SLOVENIA. Bled [Veldes], 1924 (fl), Leathes s.n. (BM); Carniolia, ad pagum St. Margarethen prope Rudolfswert, 200 m, August (l. fl), Paulin, Fl. exs. Carniol. 326 (BM).

SERBIA. bei Bor, June 1917, Koppe s.n. (JE).

BOSNIA. Sarajevsko Polji, prope Ilidža, c. 500 m, 5 August 1902 (fr), Malz s.n. (K).

MAKHEDONIJA. *L. Ochrid [Ohrid], W. of Ochrid, 25 July 1976, Akeroyd, Mellors \& Preston (CGE).

ALBANIA. North: Tepalens [Toplane?] bei Luzat, c. $250 \mathrm{~m}, 9$ September 1964 (fr), Meyer 6029 (JE); Dardha, Weg zum Qani i Dardhes, c. 800 m, 1 August 1959 (fl), Meyer 4569 (JE). South: Berat, c. 60 m, 16 August 1935 (fr), Alston \& Sandwith 2514 (BM, K).

GREECE. Thrace: Emirli, 100 m, 24 June 1931 (fl), Tedd 742 (K). Makedonia: Dramas, vill. Katafyton (SE foot of Mt. Orvilos), road to Ano Vrondou, 740 m, 23 July 1977 (fl \& fr), Strid \& Georgiadou 13052 (C); Grevenon, Mt. Smolikas, 2-3 km S. of Samarina towards Armata, 12751350 m, 27 August 1975 (1. fl), Hartvig \& Seberg 4816 (C). Ipiros: Pindus, Smokovo to Rentino, 4 August 1937 (fl), Balls \& Gourlay B. 3711 (BM, K). Corfu: Limni Korisson, near Linia, 17 July 1972 (fl), Davis 54547 (BM). Thessalia: Mt. Olympos, S. side, Leptokarya to Karya, 22.8 km, 770 m, 27 August 1975, Strid \& Hansen 9555 (C). Stereá Ellas: Attica, prope Kephissiam [Kifisiá], ad radices montis Pentelici, 195-300 m, August (l. fl). Heldreich s.n. (BM). Akhaía: Ep. Kalavryton, Mt. Chelmos (east), c. 2 km SSW of Zarouchla, 1400-1450 m, 22 August 1982 (fl), Hartvig, Franzén \& Cristensen 10296 (C). Argolos: prope Lerni, 13 July 1930 (fl), Guiol 1518 (BM). Arkhadia: Kinouria/Lakedhemonia, Mt. Parnon, Ajios Petros, Vitilithra, 1300 m, 13 July 1971 (fl), Samatiadou 13225 (BM). Evvoia: Mt. Dirphys, 24 July 1932 (l. fl), Guiol s.n. (BM). Karpathos: 0.25 km SW of Avlona, 300 m, 8 April 1992 (st), Chilton \& Turland 285 (BM). Lesvos: Agios Anagari, c. 3 km S. of Sikounta, 100-150 m, 9 September 1992 (e. fr), Hansen \& Nielsen 8030 (C).

TURKEY. Istanbul (Europe): Belgrad Forest, 31 July 1959 (fl), Yaltirik ISTO 1351 (E). Istanbul (Asia): Aydos, 20 September 1950 (fr), Baytop (\& Berk) 3603 (BM, ISTE*). Kocaeli: Izmit, Izmit to Sapanca, c. $20 \mathrm{~km}$, Masukiye, 20 July 1981 (fl), Kurtto 3088 (H). Kastamonu: N. side of Ilgaz Dağ, 1500 m, 28 July 1962 (fl), Davis, Coode \& Yaltirik D. 38288 (E, K). Giresun: above Giresun, 900 m, 24 August 1962 (fl), Furse 4137 (K). Trabzon: Of, s.l., 5 August 1957 (fl \& fr), Davis \& Hedge D.20823 (BM, E, K). Çoruh: Chope [Hopa], 6 August 1917 (fr), Shishikin s.n. (LE). Manisa: Manisa, 3 September 1932 (fl), Kotte 319 (K). Kutahya: Gediz, Şaphane, 1200 m, 27 August 1950 (fl), Davis 18505 (E). Afyon: Afyon to Sandikli, 3 km from Sinkanli [Sinanpaşa], 28 August 1971 (fl), Fraser Jenkins 2164 (BM, E). Sivas: 11 km N. of Sivas, 1300 m, 10 September 1977 (fr), Sorger 77-109-8 (Herb. Sorger). Antalya: SW of Elmali, W. of Gömbe, 1200 m, 10 July 1968 (fl \& e. fr), Sorger 68-25a-2 (BM); Gebiz, Bosburun Dağ at Panargazu yayla, 600 m, 23 July 1949 (fl), Davis 15492 (K). Hatay: Amanos dağlari, Dörtyol Pinarbaşi, 22 September 1967 (e. fr), Akman 136 (ANK, BM). 
SYRIA. Damascus, n.d. (fr), Gaillardot 910 (JE); Mt. Hermon, in valle Orny 1500 m, 2 July 1855 (fl), Kotschy 218 (BM, K, UPS).

LEBANON. Coast: Saïda, au dessus du moulin de l'Emir, 4 August 1854 (fl), Gaillardot 911 (G, JE). Lower mountains: Becharre [Bcharré], 18 August 1945 (fr), Davis 10087 (K). Al Biqáa: Bekâa, Mâlaka, July 1853 (fl), Gaillardot s.n. (JE).

IRAQ. Amadiyah: Sersang, 1050 m, 14 July 1955 (fl), Haines W.534 (K). Rawanduz: Pushtashan, 15 km NE of Rania, Qandil Range, 1150 m, 29 July 1957 (l. fl), Rawi NHI 23897 (K). Sulaymaniya: in Mt. Avroman humid., 1200-1800 m, July 1867 (fr), Haussknecht s.n. (JE).

IRAN. Gilan: Deylaman to Lanak, 600-1600 m, 9 July 1972 (fl \& fr), Termé 34320 E (BM, EVIN). Mazanderan: Astara to Bandar-Pehlevi, 15 km, 18 August 1963 (fl \& fr), Jardine 921 (E, W). Arak: in monte Raswend, August 1989 (fl), Strauss s.n. (JE). Gorgan: Ketul, June 1948 (fl), Sharif in Herb. Min. Agr. 359 (W).

AZERBAIJAN. Lenkoranskiy rayon, Port Il'ish, 17 July 1963 (fl), Bobrov \& Tzvelev 284 (LE).

ARMENIA. South-east: recorded from Dzhermuk, Shake and Goris (fide Takhtajan, 1966: 13).

GEORGIA. Batumi, Strandpromenade, 5 August 1977 (fl), Marstaller s.n. (JE); Sukhumi, E. of the town, 27 August 1957 (fr), Meyer, Lippold \& Köhler 835 (JE). Gudauta, NW bei Xirnema, 13 July 1969 (fl), Lepper; Fischer et al. 5299 (BM, JE).

RUSSIA. Stavropol: Nevinnomyssk, bei der Kuban-Brücke, 18 August 1957 (fr), Meyer, Lippold \& Köhler 18 (JE).

3b. Hypericum tetrapterum [var.] $\gamma$ corsicum (Steud.) Boiss., $\mathrm{Fl}$. orient. 1: 816 (1867) pro parte quoad typum. Type as for $H$. corsicum Steud.

Map 4.

H. tenellum Tausch in Flora 14: 211 (1831); A. Fröhl. in Sitzungsber. Kaiserl. Akad. Wiss., Math.-Naturwiss. Kl. 120: 584 (1911), non Solander ex Clarke (1812). Type: Corsica, in montibus Corsicae, Tausch s.n. (PRC-holotype).

H. corsicum Steud., Nomencl. 2nd ed., 1: 787 (1840); Godr. in Gren. \& Godr., Fl. France 1: 315 (1847); Bonnet in Bull. Soc. Bot. France 25: 280 (1878); Rouy, Ill. pl. Eur., fasc. 5: 35, t. 106 (1896). Type as for H. tenellum Tausch.

H. repens Duby ex Nyman, Consp. fl. eur. 1: 133 (1878), nomen.

H. tetrapterum var. $[\beta]$ tenellum (Tausch) Parlat, Fl. ital. 5: 518 (1875); Cesati, Passerini \& Gibellini, Comp. fl. ital.: 758 (1884).

H. acutum subsp. corsicum (Steud.) Rouy in Rouy \& Fouc., Fl. France 3: 338 (1896); Hayek, Prodr. Fl. Pen. balc. 1: 534 (1925) pro parte quoad typum; Briquet, Prodr. fl. Corse 2(2): 145 (1936); comb. illegit. (Art. 58.2).

H. quadrangulum subsp. corsicum (Steud.) Fiori in Fiori \& Paol., Fl. Italia 1: 387 (1898).

H. insulare Foucaud \& Mandon in Bull. Soc. Bot. France 47: 89, t. 2 (1900). Types: Corsica, entre le col de Sorba et Ghisoni, Mandon \& Foucaud s.n. (?); Cascade de la fontaine de Puzzichello, près de Ghisoni, Mandon, Rotgès \& Foucaud s.n. (?).

H. acutum var. corsicum (Steud.) Halácsy, Consp. fl. graec. 1: 281 (1900), comb. illegit. (Art. 58.2).

H. acutum var. insulare (Foucaud \& Mandon) Briq. in Annuaire Conserv. Jard. Bot. Genève 5: 95 (1901), comb. illegit. (Art. 58.2).

H. acutum subsp. corsicum var. rotundifolium sensu Briq., Prodr. fl. Corse 2(2): 143 (1936), non H. acutum var. rotundifolium (Willk.) Schinz $(=H$. undulatum var. boeticum $)$.

H. tetrapterum subsp. corsicum (Steud.) Zangh., Fl. Ital., 1: 196 (1976).

Icones: Rouy, Ill.pl. Eur., fasc. 5: t. 106 (1896); Foucaud \& Mandon in Bull. Soc. Bot. France 47: t. 2 (1900).

Stems procumbent to ascending, up to $0.2 \mathrm{~m}$ long. Leaves mostly 0.5 $\mathrm{mm}$ petiolate, 6-12 $\mathrm{mm}$ long, elliptic to orbicular, margin plane. Inflorescence 1(2-3)-flowered.

Montane to alpine zones; 1000-2000 m.

Corsica. The Cretan record (Bonnet, 1879) is an error (see Greuter, 1974: 156). Bonnet's record from Spain (loc. cit.) would appear to refer to small plants of 2 b. H. undulatum var. boeticum.

CORSICA. Monte d'Oro, 2000 m, 6 August 1826? (fl), Soleirol 112 (BM, K, WAG); Licano, 12 July 1912 (fl), Lacaita s.n. (BM); Bastelica, Monte Renoso, 25 August 1878 (fl \& fr), Reverchon s.n. (BM).

3c. Hypericum tetrapterum var. $[\beta]$ anagallidifolium Boiss., $F l$. orient. 1: 806 (1867); Rech.f. in Ark. Bot. 5: 294 (1960). Type as for $H$. anagallidioides Jaub. \& Spach.

Map 4.

H. anagallidioides Jaub. \& Spach, Ill. pl. orient. 1: 47, t. 24 (1842), non $H$. anagalloides Cham. \& Schltdl. (1828). Type: [Turkey (Amanus)], in oriente, Labillardière s.n. (FI-holotype, photograph!).

H. anagallidifolium Boiss., Fl. orient. 1: 806 (1867), in synon.

H. acutum var. anagallidifolium (Boiss.) Post, Fl. Syria, 2nd ed. 1: 233 (1932), comb. illegit. (Art. 58.2).

H. acutum var. anagallidioides (Jaub. \& Spach) Zohary, Fl. Palaestina 1: 223 (1966), comb. illegit. (Art. 58.2).

Icon: Jaub. \& Spach, Ill. pl. orient. 1: t. 24 (1842).

Stems ascending, slender, c. $0.15 \mathrm{~m}$ long (habit of Anagallis arvensis L.). Leaves subsessile to $0.5 \mathrm{~mm}$ petiolate, $c$. $7-12 \mathrm{~mm}$ long, elliptic to triangular-ovate, margin undulate. Inflorescence 1-3-flowered, from one node, sometimes with flowering branches from up to 5 nodes below, then totalling 20-25 flowers.

Stream banks; 1300-2000 m.

Turkey (Amanus), Lebanon, Israel.

TURKEY. Hatay: Ziaretdag, 18 September 1884 (1. fl), Post s.n. (BM); Monts Amanus, 1200-1800 m, September 1913 (fl), Haradjian 4635 (E, G).

LEBANON. Lebanon: montagne entre Saida et Deir Mekhalta près du Djoûme, n.d. (fl), Gaillardot s.n. (JE); Tripoli, Vallée de Hasroun, 7 July 1866 (fl), Blanche s.n. (JE).

ISRAEL. Upper Galilee (fide Zohary, 1966: 223).

4. Hypericum triquetrifolium Turra, Farsetia: 12 (1765); Post, Fl. Syria, 2nd ed. 1: 233 (1932); Briquet, Prodr. fl. corse 2(2): 148 (1936); Blakelock in Kew Bull. 3: 404 (1948); Quézel \& Santa, Nouv. Fl. Algérie: 682 (1963); Zohary, Fl. Palaestina 1: 233, t. 328 (1966); N. Robson in Davis, Fl. Turkey 2: 400 (1967), in Tutin et al., Fl. Europ. 2: 269 (1968), in Meikle, Fl. Cyprus 1: 300, t. 16 (1977), in Townsend \& Guest, Fl. Iraq 4: 379 (1980); Mouterde, Nouv. Fl. Liban Syrie 2: 527, t. 228 (1970); Täckholm, Students' Fl. Egypt, 2nd ed.: 150 (1974); Ali \& Jafri, Fl. Libya 2: 2, f. 1 (1976); Pott.-Alap., Fl. Tunisie: 508 (1979); Hagemann in Bot. Jahrb. Syst. 102: 247, f. 9 (1981), Hagemann \& Meusel in Flora 175: 385-405, ff. 1A, 2-8, 9B, 9C, 10A, 11 (1984), Hagemann in op. cit. 183: 284, f. 57 (1989); Demiri, Fl. Ekskurs. Shquiperise: 314 (1981?); Pignatti, Fl. Italia 1: 350 (1982); Ramos in Acta Bot. Malac. 11: 167, f. 6b (1986), in Castroviejo et al., Fl. Iberica 3: 167 (1993); Boulos, Fl. Egypt 2: 156 (1999). Type: 'Habitat in Grecia, Sicilia, Calabria'. Turra's herbarium was in the Museo civico, Vicenza, but was destroyed during the second World War (Stafleu \& Cowan, 1986).

Fig. 7, Map 5a, b.

H. crispum L., Mant. pl.: 106 (1767); Choisy, Prodr. monogr. fam. Hypéric.: 49 (1821), in DC., Prodr. 1: 549 (1824); Sibth. \& Sm., 


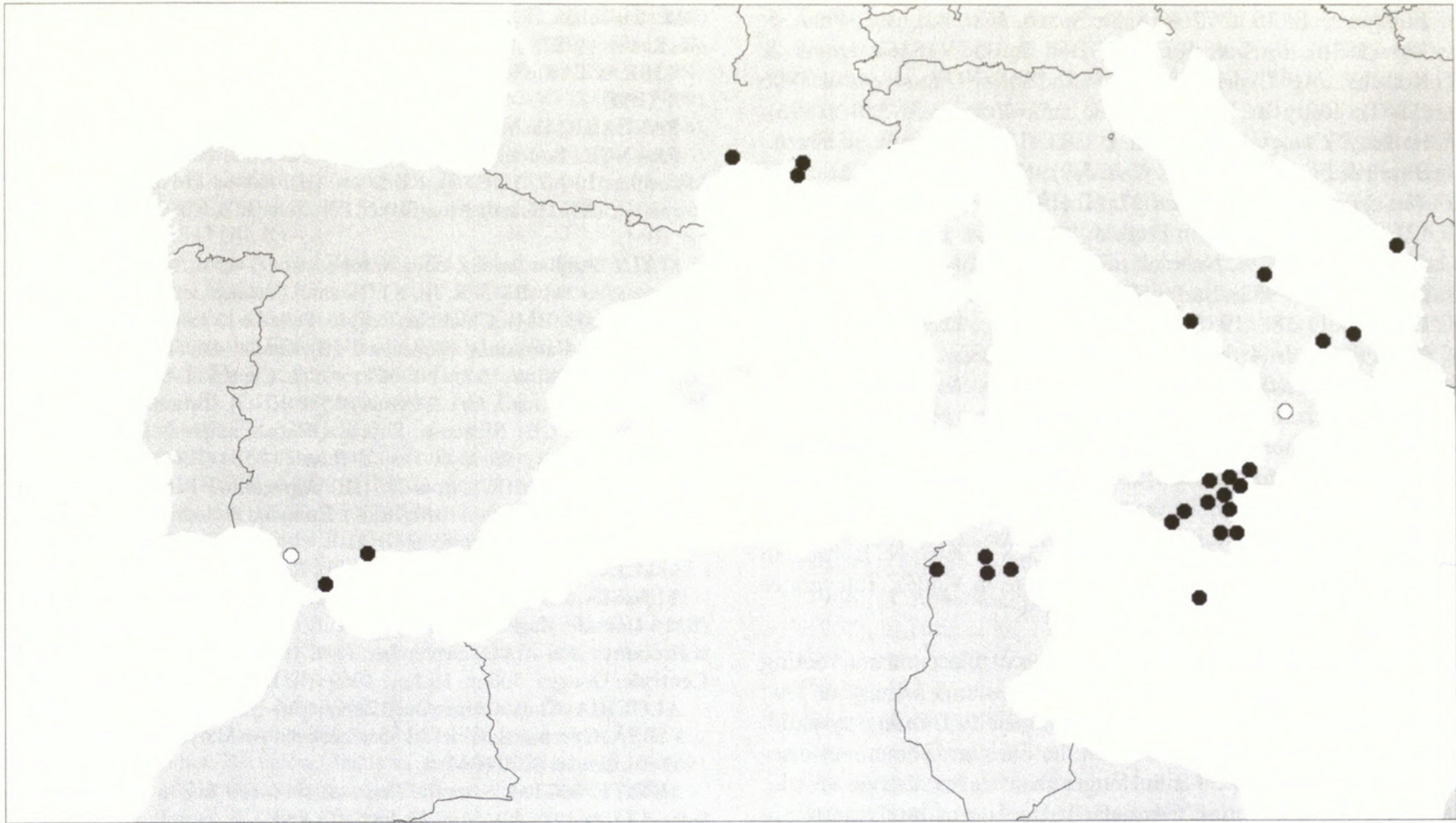

Map 5a 4. H. triquetrifolium, west area $\bullet$, other records $\bigcirc$.

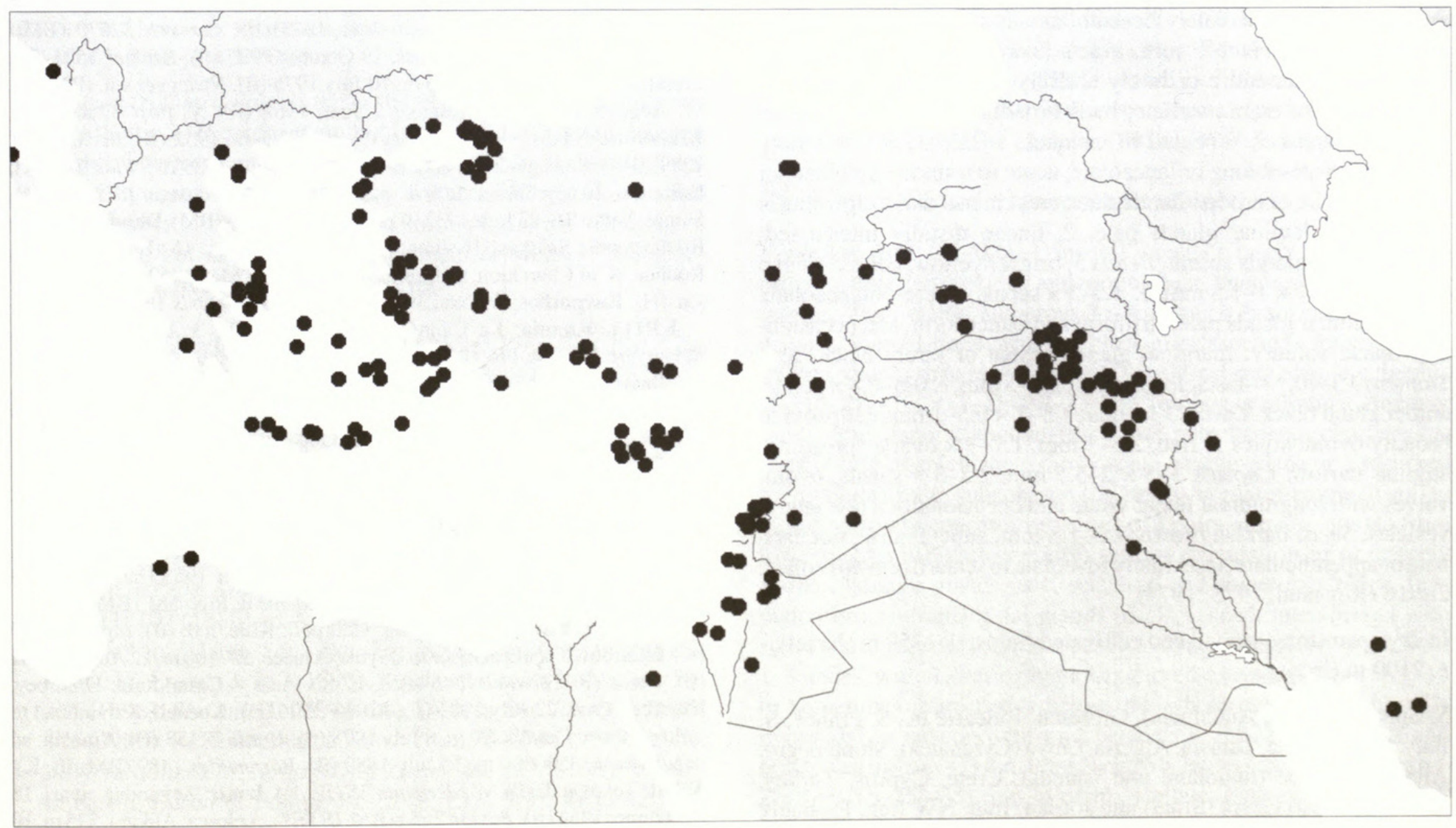

Map 5b 4. H. triquetrifolium, east area 
Fl. Graeca 8: 55, t. 776 (1833); Spach, Hist. nat. vég., Phan. 5: 385 (1836), in Ann. Sci. nat., Bot. 5: 357 (1836); Unger \& Kotschy, Ins. Cypern: 353 (1865); Boiss., Fl. orient. 1: 806 (1867); Rouy in Rouy \& Fouc., Fl. France 3: 350 (1896); Halácsy, Consp. fl. graecae 1: 283 (1900); Woron. in Kuzn., Busch \& Fomin, Fl. Cauc. Crit. 3(9): 45 (1906); Hand.-Mazz. in Ann. Naturhist. Mus. Wien 27: 60 (1913); Holmboe, Veg. Cypr: 127 (1914); R. Keller in Engl. \& Prantl, Nat. Pflanzenfam., 2nd ed. 21: 179 (1925); Nabelek in Spisy Prí. Fak. Sci. Masarykova Univ. 35: 53 (1932); Stefanoff in God. Agr-les. Fak. Univ. Sofiya 10: t. 4 f. 28 (1932), 11: 176 (1933), 12: 88 (1934), in Pflanzenareale 4: karte 6a (1933); Rech. f., Fl. Aegaea: 263 (1943); H. Lindb. in Acta Soc. Sci. Fenn., Ser. B. 2 (no.7): 23 (1946); Gorschkova in Shishkin \& Bobrov, Fl. URSS 15: 244 (1949); Täckholm, Students' Fl. Egypt: 223 (1956); Edgecombe, Weeds of Lebanon, 3rd ed.: 252 + t. (1970); nom. illegit. Type as for $H$. triquetrifolium Turra.

Icones: Zohary, Flora Palaestina 1: t. 328 (1966); N. Robson in Meikle, Fl. Cyprus 1: t. 16 (1977); Cadete in Valdés, Talavera \& Galiano, Fl. Andalucia Occid. 1: 315 (1987).

Perennial herb $0.15-0.55(-0.77) \mathrm{m}$ tall, erect to decumbent, rooting at the base, the roots bearing shoots, with stems solitary or few, widely branched along most of length, usually forming pyramid. Stems 2-lined, with black glands on the lines and sometimes elsewhere; internodes 10-30 mm, longer than leaves. Leaves sessile; lamina 3-20 × 1-9 mm, triangular-lanceolate or rarely narrowly ovate to linear-oblong, concolorous, sometimes glaucous, chartaceous; apex acute, margin crisped-undulate, base cordateamplexicaul; venation: 2-3(-4) pairs of main laterals from base or near base of midrib, tertiary reticulation usually obsolete; laminar glands pale, \pm dense, very small; intramarginal glands black, spaced. Inflorescence 1-7(-11)-flowered, from 1-2 nodes, with flowering branches \pm horizontally spreading from all other nodes, sometimes excepting 1-6 immediately beneath apical one, the whole broadly pyramidal; pedicels 1-5 mm; bracts and bracteoles $1.5-2.5 \mathrm{~mm}$ long, lanceolate, entire or rarely apically denticulate. Flowers 8$12(-14) \mathrm{mm}$ in diam., stellate; buds broadly ellipsoid to globose, rounded. Sepals 5, subequal to unequal, 1-2.2(-3) $\times 0.5-1 \mathrm{~mm}$, oblong to ovate-oblong or lanceolate, acute to rounded-apiculate or rounded, entire or eroded-denticulate, erect in bud and fruit; veins 3, unbranched; laminar glands pale, 2, linear, distally interrupted; intramarginal glands absent. Petals 5 , bright? yellow, not red-tinged dorsally, $4.5-7 \times 1-1.5 \mathrm{~mm}, c$. $3.5-5 \times$ sepals, linear-oblanceolate, entire; laminar glands pale, striiform and punctiform, and occasionally black, solitary; marginal glands absent or rarely black, few. Stamens $15-40$, '3'-fascicled, longest $2.5-5 \mathrm{~mm}$, c. $0.6-0.8 \times$ petals; anther gland black. Ovary 3-locular, $1.5-2 \times 0.5-1 \mathrm{~mm}$, ellipsoid to broadly ovoid; styles 3 , free, $2.5-3 \mathrm{~mm}, 1.7-3 \times$ ovary, spreading; stigmas narrow. Capsule 3-5 × 2-3.5 mm, 2.5-3 $\times$ sepals, ovoid; valves with longitudinal linear vittae and occasionally a few lateral vesicles. Seeds darkish brown, 1.5-1.8 mm, subcylindric, not carinate or appendiculate; testa finely foveolate to scalariform-foveolate. 2n=16 (Reynaud, 1973, 1975).

In dry open stony ground and cultivated fields; 0-1350 m (Israel), c. $2100 \mathrm{~m}$ (Iraq).

S. Spain (Málaga, Andalucia), Gibraltar, Balearic Is., S. France, S. Italy, Sicily, Malta, Tunisia, Algeria, Libya (Cyrenaica), Montenegro, Albania, Greece (mainland and islands), Crete, Cyprus, Turkey, Levant south to Egypt (Sinai) and Jordan, Iraq, NW Iran. Probably not native west of Sicily and Cyrenaica or in Montenegro.

SPAIN. Málaga: Málaga, cerca del aerodromo, May 1965 (fl), Borja s.n.
(BM); San Julian, 18 May 1952 (fl), Roivainen s.n.(H). Andalucia: Andevalo, fide Ramos (1987).

GIBRALTAR. Near First River Ferry, 26 June 1912 (fl), Wolley-Dod 1478 (BM).

BALEARIC IS. Minorca: Alayor, naturalized (fide Knoche, 1922: 188).

FRANCE. Bouches du Rhône: Les Camoins, between Neoules and Marseilles, 10 July 1968 (fl), Blaize s.n. (H); Aix-en-Provence, July 1891, Bruyas s.n. (JE). Hérault: Montpellier, Port Juvenal, July 1932 (fl), Auersmit? s.n. (BM).

ITALY. Puglia: Apulia, circa Manfredonia, 3-15 m, 28 June 1875 (fl), Porta \& Rigo 241 (BM, FR, JE, K); Taranto, Leucaspide, 30 June 1908 (fl), Lacaita 291/08 (BM). Calabria: Reggio, Pellaro, 13 July 1898 (fl \& e. fr), Rigo 472 (H). Campania: Naples, n.d. (fl), Lindley s.n. (K).

SICILY. Messina: $10 \mathrm{~km}$ NE of Taormina, Capo San Alessio, $100 \mathrm{~m}, 17$ July 1983 (fl), Akeroyd, Jury \& Rumsey 3572 (RNG). Catania: Catania, June 1885, Ross s.n. (JE). Siracusa: Siracusa, Roman amphitheatre, 100 m, 17 July 1983 (fl \& fr), Akeroyd, Jury \& Rumsey 3564 (RNG). Caltanisetta: Caltanisetta, August 1898, Ross 220 (JE). Agrigento?: Palermo a Camastra, June (fl \& fr), Todaro 1240 (BM, JE, K). Enna: ad Simethi prope Regalbuto, 28 June 1840 (fl), Heldreich s.n. (BM).

MALTA. No precise locality, 1926 (fl), Bankart s.n. (BM).

TUNISIA. Kroumerie: Ghardimaou, 22 April 1938 (fl), Simpson 38.360 (BM). Dorsale: Zaghouan, 250 m, 19 July 1969 (fl), Tomkinson 37 (BM). Kairouane: Bou-Arada, September 1898 (fl \& fr), Le Testu s.n. (BM). Centrale: Dougga, 300 m, 16 June 1969 (fl), Tomkinson 29 (BM).

ALGERIA. Constantine: Oued Zenati (fide Quézel \& Santa, 1963: 683). LIBYA. Cyrenaica: Gibel Akhdar, between Al-Marj and Beida, 25 April 1968 (fl), Boulos 3070 (BM).

MONTENEGRO. S. end of Petrovak (between Budva and Bar), Cona Gora, 12 July 1976 (fl), Halliday 88/76 (LANC).

ALBANIA. Present (fide Demiri, 1983: 315).

GREECE. Makedhonia (Khalkidhiki): $8 \mathrm{~km} \mathrm{NE}$ of Néa Moudania (ancient Olynthos), 100 m, 9 September 1981 (fl \& fr), Hussein, Jury \& Rutherford 78 (BM, RNG*); Néa Potidaia, 6 August 1971 (fl), Westfield Coll. Exped. 315 (BM). Thessalia: inter Larissa [Lárisa] et Tyrnaios, 31 July 1885, Haussknecht s.n. (JE). Stereá Ellás: S. of Athens on coastal road to Cape Sounion, 24 September 1962 (fr), Bourden 117 (BM); prope Athenas, Skaramanga, 28 May 1939 (fl), Lindberg s.n. (H). Argolís: in ruinis arcis Mykénai [Mycenae], 250 m, 26 June 1971 (fl), Černoch 22070 (BM); excavations of ancient Epidaurus, 19 October $1975(\mathrm{fl})$, Kramer $5521(\mathrm{H})$. Messinía: near Kalamata, 100 m, 10 July 1975 (fl), Nydegger s.n. (BM, H). W. Aegean Is. : Ídhra, Kamisi, 2 June 1968 (fl), N. Post 3260 (BM). Kikladhes: Naxos, inter Naxos et Chalki, 28 June 1932 (fl), Rechinger $f$. 2289 (BM). E. Aegean Is.: Khíos, Campos, 17 July 1939 (fl), Platt 362 (K); Kálimnos, ad Myrthies, c. 200 m, 3 June 1035 (st), Rechingerf. 7843 (BM); Samos, Vathy, 16-23 June 1932 (fl), Rechingerf. 1915 (BM). Dhodhekánisos: Ródhos, près Salakos, 16 June 1870 (fl), Bourgeau 16 (BM, E, G, K); Ródhos, N. of Charakion, near ruins of Fernkios, 3 May 1952 (st), Fagerstén s.n. (H). Karpathos: Avlona, 300 m, 24 July 1950, Davis 18024 (K).

KRÍTI. Khania: La Cannée, 2 July 1883 (fl), 3 August 1883 (fr), Reverchon 17 (BM, FR, H, JE, K); Kissamos [Kisámou], 20 July 1938 (fl \& fr), Davis 290 (BM). Rethímnon: Kesantopelta, 19 July 1976 (fl \& fr), Raithalme s.n. (H). Iráklion: Knossos, ruins of Knossos Palace, 18 July 1079 (fl), Lassig 7914 (H). Lasíthi: between Gournia and Tolotti, facing Psira I., 31 May 1966 (fl), Whitefoord 11 (BM).

CYPRUS. Paphos: Yeroskipos, 20 June 1939 (fl), Lindberg s.n. (H, K). Limassol: Prodhromos, 1350 m, 9 September 1955 (fl), Atherton 588 (K). Larnaca: prope Athienu [Athienou], 26 May 1862 (fl), Kotschy 972 (JE, K). Nicosia: Nicosia, English School, 150 m, 5 October 1958 (fr), Oswald 13 (K). Kyrenia: Kythraea, June 1880 (fl), Sintenis \& Rigo 581 (BM, K).

TURKEY. Europe - Tekirdağ: Gallipoli, Kilia, n.d. (fl), Ingoldby 585 (K). Istanbul: Kuçukçekmece to Büyükçekmece, 50-100 m, 12 August 1962 (fl), Davis (\& Coode) 39246 (BM, E, K). Asia - Çanakkale: Umurbey, Umurbey Çayi, 22 July 1981 (fl), Kurtto 3306 (H). Kocaeli: Karamürsel to Yalova, above Gemlik, 70 m, 8 July 1978 (fl), Uotila 27133 (H). Amasia: ad pagum Sana, 350-500 m, 10 July 1889 (fl), Bornmüller 1489 (BM, JE, K). Tokat: Tokat, n.d. (fl), Wiedermann 35 (JE, K). Izmir: Zeytindag civari, 18 September 1954 (fr), Baytop 2654 (BM, ISTE*). Ankara: Ankara, 575 m, 10 July 1939 (fl), Frödin 199 (U). Maraş: Elbistan distr., Kapidere, 31 July 1952 (fl), Davis (Dodds \& Çetik) 20419 (BM, E, K). Elazig: 60 km E. of Elazig, 1 
September 1954 (fl), Davis (\& Polunin) 24813 (BM, E, K). Bitlis: Bitlis Gorge S. of Kambos Dağ, 1250 m, 16 August 1956 (fl), McNeill 598 (E, K). Muğla: Datça to Marmaris, 4 km, 10 m, Dudley in Davis 35439 (E, K). Denizli: Pamukkale, 400 m, 28 June 1967 (fl), Sorger 67-40-18 (BM, WU*). Antalya: Manavgat to Alanya arasi, 24 July 1957 (fl), Baytop 5043 (BM, ISTE*). Içel: Silifke-Mut main road, 19 June 1971 (fl), Ayanoğlu, Sezile \& Çubukçu 1111 (BM). Gaziantep: Aintab [Gaziantep], 600 m, 16 June 1865 (fl), Haussknecht 812 (BM, E, JE, K). Mardin: Kischemill, 23 July 1888 (fl), Stapf in Sintenis 1343 (JE, K).

SYRIA. North: prope Aleppo [Halep], 1771? (fl), Russell s.n. (BM); 30 km due W. of Balad Sinjar, 7 June 1934 (fl), Field \& Lazar 685 (K) (or in Iraq?). South: Mt Hermon [Jebel esh Sheikh], 1855 (fl), Kotschy 706 (H-M).

LEBANON. Coast: bei Ghazir [Jdaidet Ghazir], c. 400 m, 19 June 1934 (fl), Busujan 220 (H-M, JE); Saïda, près de Darbesine, 28 June 1853 (fl), Blanche 950, 950a (JE, K). Lower mountains: Aïn Zhalta and higher, 1950 m, 28 August 1954 (fl), Trott 2041 (K).

ISRAEL. Samaria: $1.6 \mathrm{~km}$ outside Nazareth on Tiberias road, 15 August 1962 (fl), Curle 61 (K); Jabal Qulayb [Mt Carmel?], 1350 m, 12 June 1937 (fl), Myers \& Dinsmore 12090 (H). Judaea: Jerusalem, Mt Scopus, 13 August 1933 (fl \& fr), Amdursky 262 (H-M); Sheikh Nuran, May 1918 (fl), White s.n. (K); Ghaza, Abasan, 11 November 1964 (fl \& fr), Boulos s.n. (K).

JORDAN. near Amman, Al-Jubaiha, University Campus, 22 July 1974 (fl), Boulos 7300 (BM); 5 km S. of Shaubak, 29 June 1974 (fl), Jallad, Lahham \& Hanania 609 (H); Khanazareh [Khanasira?], 800 m, 6 October 1950 (fl \& fr), Chapman 51 (K).

EGYPT. Sinai: Rajah, 4 June 1945 (fl), Davis 10426 (K).

IRAQ. Amadiyah: Zawitah, 900 m, 27 July 1933 (e. fr), Guest in Rustam 3754 (K). Rawanduz: just below Chaklawa, Erbil liwa, 28 August 1962 (fl), Barkley \& Asker 3413 (K). Sulaimaniyah: Kirkuk liwa, Jarmo, 750 m, 22 May 1955 (fl), Haines W.226 (K). Mosul: N. of Mosul, October 1929 (fl \& fr), Dimmock in Rogers 0418 (BM, K). Nineveh: $50 \mathrm{~km}$ from Mosul to Dohuk, 410 m, 11 June 1958 (fl), Chapman in NHI 26253 (K). Arbil: 5 km N. of Erbil, 25 August 1962 (fr), Barkley 3355 (K). Kirkuk: Kor Mor, 30 km N. of Tuz, 9 June 1929 (fl), Rogers 0310A (BM, K). Diyāla: Naft Khana [Naft Khaneh], June 1929 (fl), Rogers 0320 (K).

IRAN. Kurdistan: Palangan, 1800-2100 m, 9 August 1962 (fl), Transhalr \& Termé 12298E (W). Kermanshah: Ridjab, 24 July 1962 (fl), Transhalr \& Termé 12300E (W). Fars: Kotal Pirjan, June 1960 (fl), Boroumand 5820E (EVIN*, W). Lorestan: Kouhdasht, Synareh?, 850 m, 13 August 1973 (fl), Moussari 34325E (BM, EVIN*).

Hypericum triquetrifolium is the eastern Mediterranean counterpart of the Atlantic 2. H. undulatum; but it has quite a different habitat. The habit, however, although very different at first glance, is approached by some widely branching forms of $H$. undulatum; and some of these (e.g. Valorado s.n. from Portugal, sine loc. (BM)) have rather similar but larger leaves. Hagemann \& Meusel (1984) describe it as a derived xerophilous species

5. Hypericum perforatum L., Sp. Pl.: 785 (1753), Syst. Nat. 12th ed.: 170 (1767); Choisy, Prodr. monogr. Hypéric.: 50 (1821), in DC., Prodr. 1: 549 (1824); Ledeb., Fl. altaic. 3: 364 (1831), Fl. ross. 1: 447 (1842); Spach, Hist. nat. vég., Phan. 5: 388 (1836), in Ann. Sci. nat. Bot. 5: 357 (1836); Rchb., Ic. fl. germ. helv. 6: t. 343, f. 5177 (1844); Boiss., Fl. orient. 1: 809 (1867); Maxim. in Bull. Acad. Imp. Sci. Saint-Pétersbourg 27: 432 (1882), Mélanges Biol. Bull. Acad. Imp. Sci. Saint-Pétersbourg 11: 166 (1882); S. Watson in Proc. Amer. Acad. Arts 17: 329 (1882); Coulter in Bot. Gaz. 11: 107 (1886), in A. Gray, Syn. fl. N. Amer. 1: 288 (1897); Hemsley in J. Linn. Soc., Bot. 23: 74 (1886); Rouy in Rouy \& Fouc., Fl. France 3: 332 (1896); Reiche in Anales Univ. Chile 93: 561 (1896), Fl. Chile 1: 269 (1896); Diels in Bot. Jahrb. Syst. 29: 476 (1900); R. Keller in Bot. Jahrb. Syst. 33: 554 (1904); Schinz in Vierteljahrsschr. Naturf. Ges. Zürich 49: 241 (1905); Woron. in Kuzn., Busch \& Fomin, Fl. Cauc. Crit. 3(9): 49 (1906); H.
Léveillé in Bull. Soc. Bot. France 54: 595 (1908); Pampanini in Nuovo Giorn. Bot. Ital. 17: 672 (1910); A. Fröhl. in Sitzungsber. Kaiserl. Akad. Wiss., Math.-Naturwiss. Kl. 120(1): 520 (1911), in Mitt. Naturwiss. Vereins. Steiermark 51: 240 (1915); Thellung in Allg. Bot. Z. 1912: 19 (1912); Rehder in Sargent, Pl. wilson. 3: 452 (1917); Urban, Symb. antill. 9: 406 (1925); R. Keller in Engl. \& Prantl, Nat. Pflanzenfam. 2nd ed. 21: 180 (1925); Hegi, Ill. Fl. Mitt.-Eur. 5(1): 526 (1925); Hayek, Prodr. Fl. Pen. balc. 1: 533 (1925); Fedtch. \& Shishkin, Fl. Yugo-vost 3: 711 (1930); Hand.Mazz., Symbol. sin. 7: 404 (1931); Stefanoff in God. Agr.-les. Fak. Univ. Sofiya 10: t. 4 f. 32 (1932), 11: 176 (1933), 12: 88 (1934), in Pflanzenareale 4: Karte 7 (1933); Grossg., Fl. Kavk. 3: 68 (1932), 2nd ed. 6: 175, karta 194 (1962); Gorschkova in Shishkin \& Bobrov, Fl. URSS 15: 248, t. 12 f. 1 (1949); Y. Kimura in Nakai \& Honda, Nova Fl. Jap. 10: 131 (1951); RossCraig, Draw. Brit. Pl. 6: t. 7 (1952); Guşul. \& Nyár. in Săvul., Fl. R. P. Roman. 4: 29 (1956); Gleason \& Cronquist, Man. Vasc. Pls NE. U.S. \& Canada: 469 (1963); O. Schwarz in Drudea 5: 60 (1965); Lauener in Notes Roy. Bot. Gard. Edinburgh 27: 60 (1966); N. Robson in Davis, Fl. Turkey 2: 400, tt. 12 f. 4, 13 f. 23 (1967), in Tutin et al., Fl. Europaea 2: 269 (1968), in Rechinger f., Fl. Iranica 49 (Guttif.): 17 (1968), in Nasir \& Ali, Fl. W. Pakistan 32 (Guttif.): 8, f. 2G-K (1973), in Cullen et al., Eur. gard. fl. 4: 60 (1995), in Wisskirchen \& Haeupler, Standardliste Farn- u. Blütenpfl. Deutschl.: 270 (1998); Fosberg in Occas. Pap. Berenice Pauahi Bishop Mus. 24: 22 (1969); Jordanov \& Kož in Jordanov, Fl. R. P. Bulg. 4: 260, t. 49 ff. 3, 4 (1970); Stjep.-Vesel. in Josifović, Fl. Srbije 3: 118 (1972); Anon., Iconogr. Cormoph. Sinicae 2: 879, f. 3488 (1972); Scoggan, Fl. Canada 3: 1097 (1978); Hagemann in Flora 183: 99, tt. 1-8 excl. 5B (1983); Ramos in Trab. Dept. Bot. Univ. Complut. Madrid 12: 49, t. 3 f. 2 (1983), in Acta Bot. Malac. 11: 167, f. 6a (1986), in Castroviejo et al., Fl. Iberica 3: 163, t. 45 (1993); Valdés, Talavera \& Galiano, Fl. Andalus. Occ. 1: $314+$ map \& fig. (1987); Li Xiwen in Fl. R.P. Sinicae 50(2): 67, t. 15 ff. 1-4 (1990); Biswas in Sharma \& Sanjappa, Fl. India, 3: 73, f. 27 (1993); Benson \& McDougall in Cunninghamia 4: 301 (1995); Azadi in Fl. Iran, 27: 11 + map (1999). Type: 'Habitat in Europae pratis' (probably Sweden), Herb. Linn. 943/34 (sphalm. 94) (LINN!-lectotype, Robson, 1968).

Fig. 8 (for icones and maps see under subspecies).

Perennial herb $0.2-0.6(-1) \mathrm{m}$ tall, erect or rarely decumbent to procumbent from creeping and rooting base, budding on roots late in season, ${ }^{3}$ with stems numerous to few, much branched especially distally. Stems 2-lined, with few black glands on lines; internodes 5$25 \mathrm{~mm}$, shorter than leaves. Leaves sessile to $1 \mathrm{~mm}$ petiolate; lamina (5-) 10-25(-30) $\times(1-) 3-10(-15) \mathrm{mm}$, oblong or elliptic to linear or rarely orbicular or triangular-lanceolate, paler beneath, chartaceous; apex obtuse or apiculate to rarely acute, margin plane or \pm recurved to revolute, base subcordate (or rarely cordate)-amplexicaul to rather narrowly cuneate; venation: $c .2$ pairs of main laterals from lower quarter to eighth of midrib, tertiary reticulation lax or scarcely visible; laminar glands pale, scattered and sometimes black, few, punctiform; intramarginal glands black, spaced, interspersed with small dense pale ones. Inflorescence 3- to numerous-flowered, from 1-3 nodes, with flowering branches curved-ascending from up to 15 or sometimes more nodes below, the whole cylindric to broadly pyramidal or subcorymbiform; pedicels $c .0 .5-2 \mathrm{~mm}$; bracts and bracteoles up to $4(-7) \mathrm{mm}$ long, narrowly lanceolate to linear, entire. Flowers $15-25(-35) \mathrm{mm}$ in diam., stellate; buds narrowly ovoid, 
acute. Sepals 5, equal, 3-7 × 0.7-1.5 mm, narrowly oblong or lanceolate to linear, acute to finely acuminate with acumen sometimes glandular, entire, erect in bud, recurved in fruit; veins 3(5), unbranched; laminar glands pale and often a few black, in 2(4) rows, striiform (basally) to punctiform; intramarginal glands few, black or absent. Petals 5, golden yellow, not tinged red in bud, (8-)12-15 × 5-6 mm, 3-4 x sepals, oblong to oblong-elliptic, asymmetric, distally \pm crenate; laminar glands all pale to mostly black or rarely absent (subsp. chinense pro parte), linear or partly striiform to punctiform; intramarginal glands black, distal, in sinuses when present. Stamens 40-60, '3'-fascicled, longest 6-8 mm, c. 0.5-0.7 × petals; anther gland black. Ovary 3-locular, 3-5 × 1.3-1.8 mm, narrowly ovoid to ovoid-ellipsoid; styles 3, free, 4-6 mm, c. 1.5-2 $\times$ ovary, broadly to rather narrowly spreading; stigmas narrow. Capsule 3-10 $\times 3-6 \mathrm{~mm}, 0.7-1.5 \times$ sepals, narrowly to broadly ovoid or narrowly ovoid-conic; valves with dorsal vittae and lateral vittae or yellowish, striiform to punctiform vesicles. Seeds dark brown, $c .1$ $\mathrm{mm}$, cylindric, not carinate or appendiculate; testa finely linearfoveolate. $2 \mathrm{n}=32$ (Noack, 1939, Mulligan, 1957 et auct. plur.; $\mathrm{n}=16$, Nielsen, 1924, Hoar \& Haertl, 1932, Noack, 1939 et auct. plur.), 48 (Noack, 1939, Robson, 1981, Ciccarelli, Garbari \& Mártonfi, 2001), 2n=16 (Schwarz, 1965, as H. veronense; Strid \& Franzén, 1981, as var. angustifolium; Papanicolaou, 1984, Ciccarelli, Garbari \& Mártonfi, 2001, as H. perforatum).

Open woodland, meadows, grassland and steppes, riverbanks, stony and grassy slopes, roadsides, in dry or well-drained habitats; 10-c. $2750 \mathrm{~m}$ (China), -2780 m (Tajikistan), -3150 m (Afghanistan).

General distribution of the species: Europe (except extreme north), north-west Africa, Canary Is., Madeira, Azores; Turkey, Cyprus, the Levant and western Saudi Arabia to north-west India (Uttar Pradesh), Transcaucasia, Turkmenistan to Altai, Angara-Sayan and NW Mongolia; China (W. Xinjiang and from Gansu east to Hebei, south to Jiangxi and west to Yunnan). Introduced into many other parts of the world, viz. Canada, U.S.A., Mexico, Cuba, Haiti, Brazil (Paraná), Uruguay, Argentina, Chile, Juan Fernandez, Sudan Rep. (Jebel Marra), S. Africa, Réunion, Australia, New Zealand, Japan.

Hypericum perforatum is apparently an allotetraploid $(2 \mathrm{n}=32)$ (Gustafsson, 1947; Robson, 1958a, 1975), which, for reasons of morphology and geography, would appear to have arisen from a cross between two diploid taxa $(2 \mathrm{n}=16)$, viz. 1a. H. maculatum subsp. immaculatum (Balkans) and 6. H. attenuatum (western Siberia to China). Morphologically it (or, rather, typical broad-leaved var. perforatum) is close to $H$. maculatum, but it differs in the 2-lined stem internodes, the more oblong leaves with lax reticulate venation and rather dense pale laminar gland dots, the lanceolate acute sepals, and the petals with black marginal glands, characters that all tend towards $H$. attenuatum. It differs from both presumed parents in its capsule valves with oblique vittae or vesicles, a glandular pattern that is unique in sect. Hypericum (of which it is the type species). The presence of linear laminar glands in the petals and pale laminar leaf glands suggests that the maculatum parent was var. immaculatum rather than var. maculatum, with its punctiform to striiform petal glands and usual lack of pale laminar leaf glands. If, as seems probable, the ancient hybridization occurred in Central Asia (the Altai region?), then (i) the current restricted distribution of var. immaculatum in the Balkans is a relict of a much wider one, and (ii) the extension of the current distribution of var. maculatum into Central Asia is relatively recent.

Cytologically, H. perforatum behaves as a hybrid (Noack, 1939;
Gustafsson, 1946-47; Mártonfi et al., 1996a). The pollen undergoes normal reduction division; but meiotic abnormalities (lagging chromosomes) lead to sterility that is usually about $30 \%$ but can be up to $70 \%$ (Nielsen, 1924; Hoar \& Haertl, 1932). Only c. $3 \%$ of the embryo sacs are produced by normal meiosis $(n=16)$, the remaining (unreduced) ones being produced parthenogenetically $(n=32)$. The latter, however, are pseudogamous, i.e. they require pollination for seed development. Fertilization is therefore possible, though not necessary. Occasionally the $\mathrm{n}=32$ embryo sacs are fertilized, resulting in hexaploid $(2 \mathrm{n}=48)$ plants. The records of $H$. perforatum with $2 \mathrm{n}=16$ chromosomes (see p. 63) would appear to be from dihaploids, i.e. from plants that have resulted from the development of reduced but unfertilized embryo sacs. Since in allotetraploids (i) each chromosome is duplicated and (ii) the more different the parents are, the less is the likelihood that there will be multiple chromosome associations, it seems reasonable to expect dihaploids to occur in $H$. perforatum. Two of these occurrences have been reported in the more reduced forms of the species (var. angustifolium and var. microphyllum), and two (Papanicolaou, 1984; Ciccarelli, Garbari \& Mártonfi, 2001) were in H. perforatum without qualification. Gagnieu \& Wilhelm's report (1965) of $\mathrm{n}=12$ for var. angustifolium is no doubt either a miscount for $n=16$ or, just possibly, from fertilization by a triploid pollen grain. This cytological variation is accompanied by wide morphological variation, which is complicated in the wild by 'back-crosses' to at least two of the subspecies of $H$. maculatum (Robson, 1981: 168, f. 55) (see p. 104).

The morphological variation in $H$. perforatum, though great, appears to be continuous and therefore theoretically indivisible. For reasons of practicality, however, it is convenient to recognize some previously described variants as subspecies ${ }^{4}$, a rank that reflects their geographical basis better than the hitherto more usual varieties. For one well-known taxon, however, even this is impossible. The southern European plants with narrow leaves and vesicular capsule vittae ('var. angustifolium DC.') cannot be separated from those with small (narrow to broad) leaves and similar capsule vittae ("var. microphyllum DC.'). Indeed, the latter are probably polyphyletically derived from the former, and some may be merely the result of habitat-induced variation. Bearing in mind these reservations, the overall variation in $H$. perforatum can be described and classified in four intergrading subspecies.

(a) From its presumed origin in western Siberia into northern and central Europe and eastward into NW Mongolia the initially sessile leaves become gradually shortly petiolate (although remaining sessile in northern Russia (always?) and sometimes in Scandinavia), and the base changes from rounded to broadly cuneate, the capsule vittae remaining continuous and almost always narrow. This is the type form (subsp. a. perforatum). In dry habitats the leaves become narrow with revolute margins, thus superficially resembling a form of subsp. veronense (see c. below); but the leaves are petiolate and the capsule glands are different. Such plants have frequently been recorded as "var. angustifolium DC.', but the vesiculate capsule vittae differ from those of similar forms of subsp. veronense. Where the capsule is vesiculate (as it is, for example, in southern England on chalk, sand, wall-tops, etc.), such capsules are derived from continuous lateral vittae, as is shown by the occurrence of intermediate states. True 'var. angustifolium' would appear to have been derived from forms in which the lateral vittae have been interrupted before becoming enlarged and vesiculate. Another development of vesiculate capsules of this type in subsp. 
perforatum has occurred in the southern Balkans. In the mountains of Bulgaria and northern Greece there are erect to procumbent plants with small, obovate to orbicular leaves and capsules with lines of flattish vesicles ('var. humile Stranski'). These are interpreted here as an extreme montane development of subsp. perforatum, there being continuous variation from (i) typical subsp. perforatum to (ii) a smaller-leaved form with rather dense inflorescences and small fruits, then to (iii) a similar, decumbent form with capsule valves having two lines of flattish 'vesicles', and finally to (iv) a dwarf form with small narrower leaves.

(b) Both presumed parents have sessile leaves, with the base rounded in $H$. maculatum and subcordate to cuneate in $H$. attenuatum. Therefore the one variant of $H$. perforatum with sessile cordateamplexicaul leaves would also appear to have a good claim to at least approach the primitive form. This is subsp. b. songaricum (var. songaricum (Ledeb. ex Rchb.) K. Koch), of which the tallest plants with the largest leaves and most luxuriant growth (approaching those of the presumed parental species) occur in eastern Kazakhstan and probably also in NW Xinjiang. The leaves become gradually smaller southward (Kyrgyzstan - ' $H$. komarovii') and westward (W. Kazakhstan, S. Russia and the southern Ukraine - var. 'gracile ') and in dry regions develop a glaucous lower surface and recurved margins.

(c) From the Caucasus region into eastern Turkey and northern Iran narrower-leaved plants become frequent ('var. collinum' Woron.), and the capsules, which are still relatively large, have interrupted and often somewhat swollen oblique vittae. The leaves then become first narrower and then smaller (often with revolute margins) eastward into central Asia (Tadjikistan) and India (east along the Himalaya to Uttar Pradesh) and westward into the Mediterranean region, where the typical narrow-leaved and small-leaved plants of subsp. veronense (= respectively var. angustifolium DC. and var. microphyllum DC.) occur and extend into Macaronesia, NW Africa, SW Saudi Arabia (Asir) and the Sudan Republic (Jebel Marra), although whether its occurrence in Jebel Marra is natural is doubtful (Wickens, 1976b: 76, 99, map 59). It has been introduced into various other countries and continents. Where its distribution meets that of subsp. perforatum in southern and central Europe, the intermediate forms that occur are presumably hybrid in origin, unless subsp. veronense has arisen polyphyletically in southern Europe, the Caucasus region and (possibly) Central Asia. In the trends in this subspecies the leaves first become narrow (vars collinum, angustifolium) and then small (var. microphyllum=subsp. veronense); but in relatively mesophytic areas these small leaves may become broad again (e.g. var. ellipticum Freyn non Durand \& Pittier in mountain Turkmenistan).

(d) In China, after a gap in distribution from NW Mongolia to Gansu and adjacent Qinghai (where some specimens closely approach subsp. perforatum in form), there is a southward trend to Yunnan and Guizhou in which the leaves and flowers become smaller, the latter being crowded in small (terminal and lateral) inflorescences at the end of elongated branches (subsp. d. chinense). This subspecies has been introduced into Japan (' $H$. foliosissimum Koidz.').

5a. Hypericum perforatum subsp. perforatum Stjep.-Vesel. in Josifović, Fl. Srbije 3: 118 (1972); Ramos in Castroviejo et al., Fl. Iberica 3: 165, t. 45 ff. f-j (1993).

Fig. 8, Maps 6-8.

H. officinarum Crantz, Stirp. austr. 2: 66 (1763), 2nd ed.: 99 (1769);
Moench, Methodus: 129 (1794), nom. illegit. Crantz cites the Sp. pl. phrase name (except 'Floribus trigynis') and number. Type as for $H$. perforatum $\mathrm{L}$.

H. vulgare Lam., Fl. France 3: 151 (1778); Rupr. in Mém. Acad. Imp. Sci. Saint-Pétersbourg 7, Sér. 15, no. 2: 248 (1869), nom. illegit. Type as for $H$. perforatum $\mathrm{L}$.

H. officinale Gaterau, Descr. pl. Montauban: 135 (1789); Steud., Nomencl. Bot.: 421 (1821) qua syn.; Raynal in Taxon 17: 516 (1968), nom. illegit. Type as for $H$. perforatum $\mathrm{L}$.

$H$. perforatum var. $[\beta]$ sensu Choisy, Prodr. monogr. fam. Hypéric.: 50 (1821).

? H. perforatum var. [ל] albiflorum Choisy in DC., Prodr. 1: 550 (1824). Type: not found (1974).

H. perforatum var. vulgare Schimp. \& Spenn. in Spenn., Fl. friburg 3: 888 (1829); Neilr., Fl. Nied.-Oesterr. 2: 826 (1859); Hegi, Ill. Fl. Mitt.-Eur. 5(1): 528 (1925); Briquet, Prodr. fl. Corse 2(2): 150 (1936); Guşul \& Nyár. in Şavul., Fl. R. P. Roman. 4: 29 (1956); Grossg., Fl. Kavk. 2nd ed. 6: 175 (1962). Type as for H. perforatum L.

H. marylandicum Biroli ex Colla, Herb. pedem. 1: 467 (1833), 7: 97 , t. 50 f. 2 (1837). Type: no locality cited, Herb. Birol. (TOholotype, photograph!).

H. perforatum var. [ $\gamma]$ latifolium sensu W. Koch in Rohling, Deutsch Fl. 3rd ed. 5: 349 (1839), Syn.fl. germ. helv. 2nd ed. 1: 146 (1843), Syn. deut. schweiz. Fl. 2nd ed. 1: 155 (1846) pro parte omnes excl. typum. The type of Koch's var. latifolium is that of var. latifolium Gaudin (1829), which he cites; his specimens (L) are typical $H$. perforatum subsp. perforatum. See $5 \mathrm{xbb} . H . \times$ desetangsii nothosubsp. carinthiacum nothoforma perforatiforme for Gaudin's plant.

H. assurgens Peterm., Anal. Pfl.-Schlüssel: 67 (1846), in synon.; Rouy in Rouy \& Fouc., Fl. France 3: 337 (1896). Type: Germany, Leipzig, bei Roumaritz, Petermann s.n. (W!-holotype). The 'type specimen' appears to be pure $H$. perforatum, not $H$. humifusum $\times$ perforatum as reported by Rouy \& Foucaud; and the name does not appear on Petermann's Fl. Lips.: 563 (1838) as cited by them.

H. perforatum var. petiolatum Peterm., Anal. Pfl.-Schlüssel: 67 (1846). Type: Germany, Leipzig, Konnevitz, Petermann s.n. $(\mathrm{LZ} \dagger)$

H. lineolatum Jord. in F.W. Schultz, Arch. fl. France Allem. 1: 343 (1854). Type: France, Ain, 'montagnes du Bugey à Junnimont', Jordan s.n. (LY-lectotype, selected here; BM!-isolectotype).

? H. deidesheimense Sch. Bip. ex Trev., Hyper. sp. animadv.: 10 (1861). Type: Germany, Rheinhessen-Pfalz, Deidesheim, SchultzBip. s.n. (P?-holotype).

H. perforatum var. alpinum Parl., Fl. Ital. 5: 512 (1872); Fiori \& Paol., Fl. Italia 1: 388 (1898); A. Fröhl. in Sitzungsber. Kaiserl. Akad. Wiss., Math.-Naturwiss. Kl. 120(1): 524 (1911). Type: Italy, Piemonte, sopra i Bagni di Valdieri al Vallasco nella regione superiore del Faggio, 1300 m, Parlatore s.n. (FI-lectotype, Ciccarelli, Garbari \& Robson, 2002); come pure nella regione superiore dell'Abeto del Monte Cramont', Parlatore s.n. (FIsyntype). Fröhlich (1911: 524) compares (synonymizes?) this with his forma lineolatum of subsp. vulgare.

H. perforatum var. anomalum Frid. in Lange, Haandb. Danske fl. 4th ed.: 700 (1887). Type: Denmark, Slesvig [Sœderjylland], Haderslev, 1886 (fl), Haspelmath s.n. (C!-holotype).

H. perforatum var. $[\alpha]$ typicum Beck, Fl. Nieder-Österr. 2: 530 (1892); Fiori \& Paol., Fl. Italia 1: 388 (1898). Type as for $H$. perforatum.

H. perforatum var. vulgare subvar. lineolatum (Jord.) Rouy in Rouy \& Fouc., Fl. France 3: 333 (1896). Type as for H. lineolatum Jord. H. perforatum var. ellipticum Durand \& Pittier in Bull. Soc. Roy. 


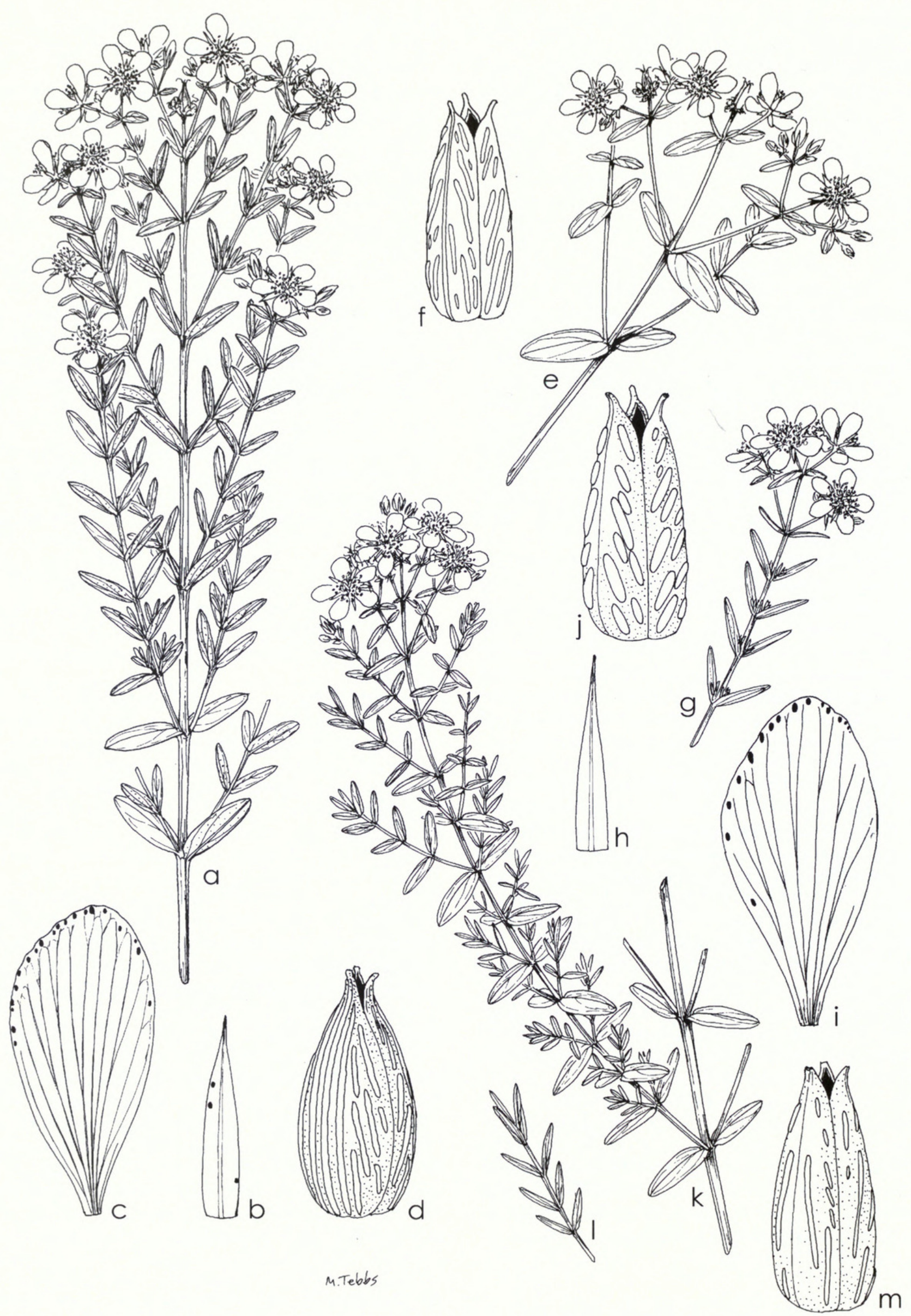

Fig. 8 H. perforatum. A. subsp. perforatum: (a) habit; (b) sepal; (c) petal, omitting laminar glands; (d) capsule. B. subsp. songaricum: (e) branch; (f) capsule. C: subsp. veronense: (g) branch; (h) sepal; (i) petal, omitting laminar glands; (j) capsule. D. subsp. chinense: (k) stem and branch; (l) leaves (depauperate); (m) capsule (a, e, g, k, $1 \times 2 / 3$; rest $\times 6$ ). A. (a-c) Martinez s.n.; (d) Sennen s.n. B. (e, f) Becker s.n. C. (g-i) Riera et al. 17197; (j) Lacaita 28. D. (k) Wilson 2425; (1) Bullock s.n.; (m) Father Hugh s.n. 
Bot. Belgique 20: 80 (1881). Type: Switzerland, Vaud, bois près de Rolle, fide 'H. perforatum [var.] a' sensu Rapin, Cat. fl. vaud., 2nd ed.: 123 (1862) (G?-holotype). Hegi (1925: 528) reduced this to a form of var. vulgare.

H. vulgare Bubani, Fl. pyren. 3: 345 (1901), non Lam. (1778). Bubani ascribed this name to pre-Linnaean authors.

H. perforatum var. normale Woron. in Kuzn., Busch \& Fomin, $F l$. Cauc. Crit. 3(9): 56 (1906). Type as for $H$. perforatum L.

H. perforatum subsp. vulgare (Schimp. \& Spenn.) A. Fröhl. in Sitzungsber. Kaiserl. Akad. Wiss., Math.-Naturwiss. Kl. 120(1): 522, f. 2 (1911), in Mitt. Naturwiss. Vereins Steiermark 51: 240 (1915); Hayek, Prodr. Fl. Pen. balc. 1: 533 (1925).

H. perforatum subsp. vulgare forma brevisepalum A. Fröhl. in Sitzungsber. Kaiserl. Akad. Wiss., Math.-Naturwiss. Kl. 120(1): 524 (1911). Type: Austria, Styria, Gösting bei Graz, 11 July 1909 (fl), Fröhlich GZU16368 (GZU!-lectotype, selected here).

H. perforatum subsp. vulgare forma lineolatum (Jord.) A. Fröhl. in Sitzungsber. Kaiserl. Akad. Wiss., Math.-Naturwiss. Kl. 120(1): 524 (1911), in Mitt. Naturwiss. Vereins Steiermark 51: 240 (1915). Type as for H. lineolatum Jord. Fröhlich also describes this taxon in adnot. as 'subvar. lineolatum', a later homonym than that of Rouy (1896).

H. perforatum subsp. vulgare forma lucidum A. Fröhl. in Sitzungsber. Kaiserl. Akad. Wiss., Math.-Naturwiss. Kl., I, 120(1): 524 (1911), in Mitt. Naturwiss. Vereins Steiermark 51: 240 (1915). Type: Austria, Styria, Stiftingtal bei Graz, 26 July 1910 (fl), Fröhlich GZU16378 (GZU!-lectotype, selected here).

H. perforatum var. humile Stranski (date?) [description not found]; Stoj. \& Stef., Fl. Bulg.: 774 (1948); Stoj., Stef. \& Kitan., Fl. Bulg. 2: 720 (1967). Type: Bulgaria (SO).

H. perforatum var. vulgare forma brevisepalum (A. Fröhl.) Hegi, Ill. Fl. Mitt.-Eur. 5(1): 528 (1925).
H. perforatum var. vulgare forma anomalum (Frid.) Hegi, Ill. Fl. Mitt.-Eur. 5(1): 528 (1925).

H. perforatum var. vulgare forma lineolatum (Jord.) Hegi, Ill. Fl. Mitt.-Eur. 5(1): 528 (1925), sphalm. 'lanceolatum'.

H. perforatum var. vulgare forma lucidum (A. Fröhl.) Hegi, Ill. Fl. Mitt.-Eur. 5(1): 528 (1925).

H. perforatum subsp. vulgare var. lineolatum (Jord.) Hayek, Prodr. Fl. Pen. balc. 1: 533 (1925).

H. perforatum var. ceretanicum Sennen, ined.? 'Type': Spain, Lérida, La Cerdaña, Targassonne, 1600 m, 15 September 1916 (fr), Sennen s.n. (BC, BM!).

H. perforatum var. decompositum Nyár. in Bul. Gräd. Bot. Univ. Cluj 19: 85 (1939); Guşul. \& Nyár. in Săvul., Fl. R. P. Roman. 4: 29 (1956). Type: Romania, Transsilvania, distr. Treiscaune, ad balneas Şugaş, supra opp. Sf. Gheorghe, 7 September 1928 (fr), Nyárády s.n. (CL-holotype, photocopy!).

H. perforatum var. semihumifusum Nyár. in Bul. Şti. Acad. Republ. Populare romîne, Sect. Şti. Biol. etc. 7: 226, t. 2 f. 3 (1955); Guşul. \& Nyár. in Sávul., Fl. R. P. Roman. 4: 29 (1956). Syntypes: Romania, Walachia, Piteşti, Mt. Cozia, 1200-1400 m, 17 May, 20 June \& 19 August 1950 (fl \& fr?), Nyárády s.n. (CL).

H. perforatum subsp. perforatum var. pellucidum O. Schwarz in Drudea 5: 61 (1965), nom. illegit. (Art. 37.1). Type: none cited. H. perforatum var. perforatum - N. Robson in Wisskirchen \& Haeupler, Standardliste Farn- u. Blütenpfl. Deutschl.: 270 (1998).

Icones: Rchb., Ic. fl. germ. helv. 6: t. 343, f. 5177 (1844); RossCraig, Draw. Brit. Pl. 6: t. 7 (1952); Ramos in Castroviejo et al., Fl. Iberica 3: t. 45 ff. f-j (1993).

Leaves usually petiolate; lamina (5-)12-25(-30) $\times(2-) 5-10 \mathrm{~mm}$, broadly to narrowly oblong or ovate to rarely elliptic or orbicular or obovate $(1: b=(1-) 2-3(-5))$, base rounded to broadly cuneate, not

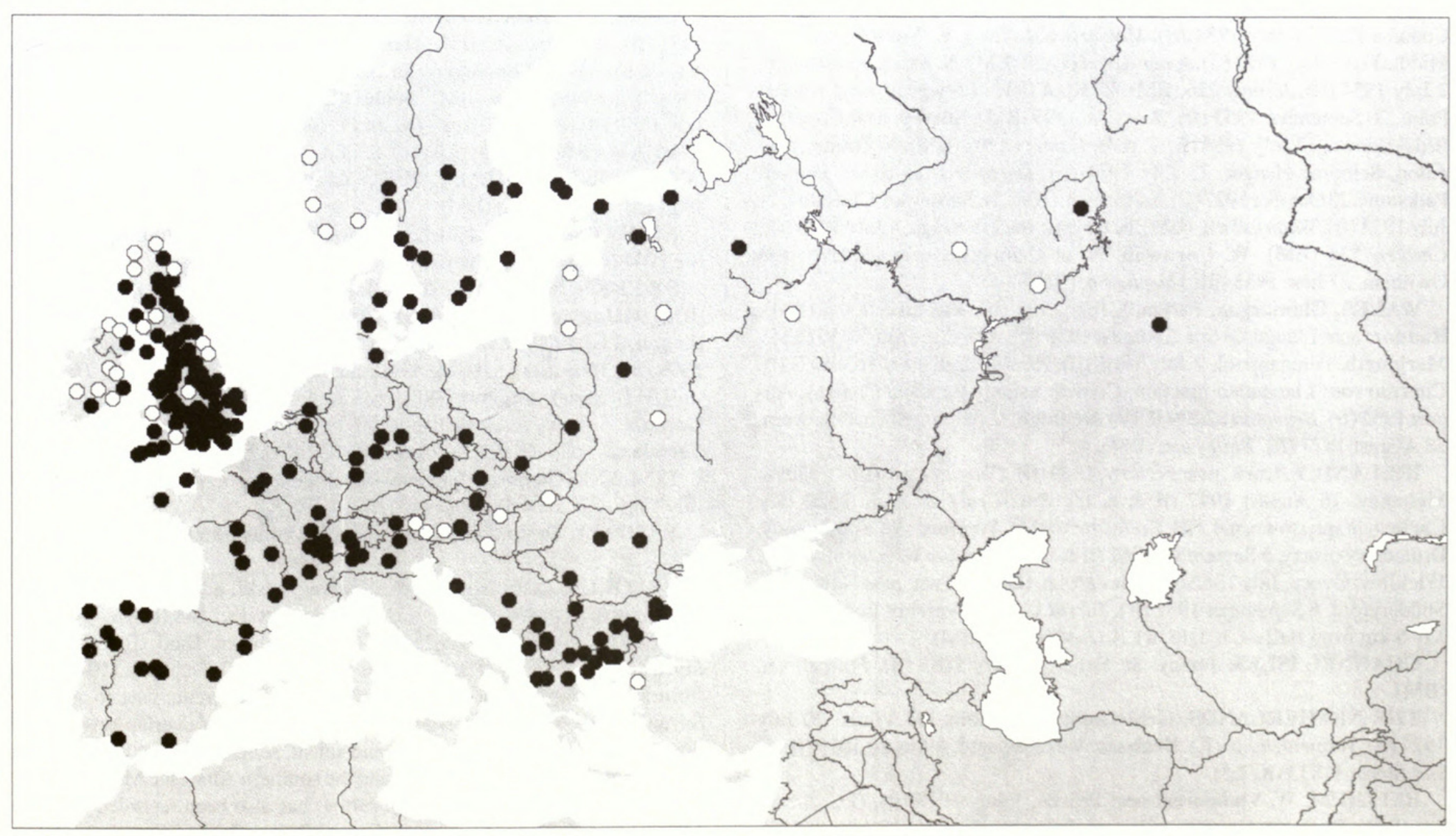

Map 6 5a. H. perforatum subsp. perforatum, Eurasia , other records $\bigcirc$. The north European plain, Bavaria and the upper Danube region under-represented. 
glaucous beneath. Inflorescence not usually congested, with branches relatively short, straight. Petals with laminar glands all pale to mostly black. Capsule valves with lateral vittae linear, narrow or rarely swollen distally but not interrupted, the vesicles forming a regular row, not scattered irregularly.

Distribution of the species excluding (i) the Mediterranean region, Macaronesia, Jebel Marra, SW Saudi Arabia (Asir), nearly all Asiatic Turkey, Transcaucasia and Iraq to NW India; (ii) Kazakhstan and adjacent southern Russia; (iii) China. Introduced into North America, Mexico, Cuba, Haiti, Brazil (Paraná), Uruguay, Argentina, Chile, Juan Fernandez, Hawaiian Islands and possibly New Zealand and Australia (no confirmed records).

SCOTLAND. Sutherland: Kildonan, 1882 (Anthony, 1976: 64). Easter Ross: Strathpeffer, 1967 (Duncan, 1980: 40). Inverness: Beauly, 1954 (McCallum Webster, 1978: 115). Moray: Forres, near Greshop House, 12 August 1961 (fl), McCallum Webster 5864 (K). S. Aberdeen: Ballater, mouth of R. Muick, 30 July 1955 (fl), Robson s.n. (BM). Forfar: Clova, Birkhill, n.d. (fl), Gardiner s.n. (BM). Mid Perth: Aberfeldy, July 1929 (fl), Meinertzhagen s.n. (BM). Stirling: Loch Lomond, Balmaha, 30 July 1962 (fl), Kenneth s.n. (BM). Mid Ebudes: Mull, Achnadrish, July 1968 (e. fl), Kingston s.n. (BM). Midlothian: Inveresk, 1851 (fl), Syme s.n. (BM). Berwick: Nenthorn parish, near Newton Don, 3 August 1960 (fl), Bangerter 948 (BM). Kirkcudbright: Tongland, July 1883 (fl), Coles s.n. (BM).

ISLE OF MAN. Peel, 5 September 1944 (fl), Paton s.n. (BM).

ENGLAND. Cumbria: Seascale, September 1903 (fl), N. Simpson 3025 (BM). Northumberland: Middleton Hall, Wooler Water, 4 July 1958 (bud), Bangerter 645 (BM). NE Yorks.: near Hill Ghyll, 4 August 1926 (fl), Foggitt s.n. (BM). Mid-W. Yorks.: Arncliffe village, 18 July 1959 (fl), Gerrans 717 (BM). E. Yorks.: Wauldley, 2 August 1951 (fl), Radford s.n. (BM). S. Lancs.: Liverpool, Oglet, 13 July 1972 (fl), Greenwood s.n. (LIV). Notts.: Budby, Fanny's Grove, 20 July 1963 (fl), Bowden \& Hillman 37 (BM). S. Lincs: Grantham, Sattersford, 19 July 1913 (fl), Fishers.n.(BM). Shropshire: Ferny Dingle, 10 July 1961 (fl), Butler \& Milward 415 (BM). W. Gloucs.: Tidenham, 16 July 1909 (fl), Riddelsdell s.n. (BM). Bucks.: 1.6 km SE of Ellesborough, Coombe Hill, 28 July 1954 (fl), Melderis 681 (BM). E. Norfolk: Lopham Middle Fen, 3 July 1973 (fl), Jones \& Vickery 29 (BM). N. Essex: Berechurch, 2 July 1954 (fl), Jermyn 226 (BM). E. Kent: Isle of Sheppey, near Warden Point, 20 September 1953 (fr), Bangerter 205 (BM). Surrey: near Croydon, Riddlesdown, 17 July 1954 (fl), J. \& M. Cannon 2761 (BM). N. Hants.: near Alton, Selborne Hanger, 22 July 1974 (fl), Gerrans 1817 (BM). Dorset: Parkstone, 23 October 1927 (fr), Salmon s.n.(BM). N.Somerset: Clevedon, 11 July 1934 (fl), Waterfall s.n. (BM). S. Devon: Buckfastleigh, 4 July 1973 (fl), Chicken 524 (BM). W. Cornwall: N. of Camborne, near Godevry and Gwithian, 27 June 1953 (fl), Murphy s.n. (BM).

WALES. Glamorgan: Parkmill, July 1903 (fl), Riddelsdell s.n. (BM). Radnor: near Llangunlo Stn, 5 August 1956 (fl), P.C. \& J. Hall 52/56 (BM). Merioneth: Penmanpool, 7 July 1961 (fl), Raven [\& Benoit] 16308 (BM). Caernarvon: Llandudno junction, Conway estuary opposite Conway, August 1962 (fr), Brummitt 62.224 (LIV). Denbigh: S. of Llangollen, Pengwern, 28 August 1877 (fl), Bailey s.n. (BM).

IRELAND. E. Cork: near Fernroy, 1849 (fl), Chandlee s.n. (BM). Mayo: Mulranny, 16 August 1947 (fl \& e. fr), Ross-Craig \& Sealy 1520 (K). Carlow: Staplestown, n.d. (fl), Collector? (BM). Wexford: W. of Bunclody, Drumderry quarry, 5 September 1962 (fl \& fr), Mc Callum Webster 8048 (K). Wicklow: Ovoca, July 1882 (fl), Fawcett s.n. (BM). Down: near Newcastle, Slidderyford, 6 September 1952 (fr), Turrill s.n. (K). Antrim: Logan Canal, 1.6-5 km from Belfast, n.d. (e. fr), A.G. More s.n. (BM).

CHANNEL ISLES. Jersey: St. Helier, 14 July 1883 (fl), Fawcett s.n. (BM).

THE NETHERLANDS. Gelderland: Bennekom, b/d Vijrus, 20 July 1927 (fl), Vermeulen s.n. (K). Brabant: Valkenswaard, 4 August 1979 (fl), P. van Royen $11833\left(\mathrm{~K}, \mathrm{~L}^{*}\right)$.

BELGIUM. W. Vlanderen: near Proven, 1 July 1918 (fl), G.C. Brown s.n. (BM). Brabant: Opwijk, vallei van de Brabantse beek, 18 August 1981 (fl), Robrecht 1533 (BM, BR*). Hainault: Obourg, 8 August 1862 (fr), Martinis in van Huerck I 42 (BM, K). Namur: Wavreille, June 1914 (fl), G.A.B. s.n. (BM).
FRANCE. Ardennes: Rethel, 1 August 1897 (fr), Gérard in Soc. Rochel. 4049 (BM). Oise: Paris, forêt de Chantilly, 15 June 1912 (fl), Ronniger s.n. (W). Hts de Seine: Bois de Meudon près Paris, October 1875 (fl), Bonnet s.n. (K). Finisterre: Brittany, Haelgost, 22 July 1913 (fl), Perrycoste 3639 (BM). Loire atl.: Mauves, July 1860 (fl), Gadeceau s.n. (BM). Maine-et-Loire: la route à Montfaucon s. Moine, 10 July 1888 (fl), Gadeceau s.n. (BM). Hte Vienne: Le Dorat, 21 July 1929 (fl), Jalicon s.n. (BM). Cher: Noirlac, 22 June 1864 (fl), Déséglise s.n. (BM). Hte Saône: entre le Loritellet et le mont près Conflans, 2 August 1856 (fl), Perrier 277 (BM). Jura: Salins les Bains, 425 m, 15 August 1892 (fl), Deschamps (BM, BR*). Hte Savoie: Mont Salève, 29 July 1922, Lacaita 29/22 (BM). Savoie: Belleville, 300 m, 2 September 1861 (fr), Perrier in Billot 3349bis (BM). Puy de Dôme: Auvergne, Mont Dore, August 1920 (fl), Norman s.n. (BM).

ANDORRA. Vallée du Valira, July 1933 (fl), Font in Sennen s.n. (BM).

SPAIN. La Coruña: near Coruña, August 1888 (e. fr), Guardia s.n. (BM). Orense: $c .50 \mathrm{~km}$ E. of Orense, Monte Manzaneda, $1410 \mathrm{~m}, 22$ August 1982 (fl), Goyder \& Jury 606 (BM, RNG). Santandér: Picos de Europa, between Fuente Be and Espinama, 877-1200 m, 5 August 1969 (e. fr), Grimes 319 (BM, RNG). Viscaya: Monasterio de Nuestra Señora de Guadalupe, Cáceres, 24 June 1958 (fl), Guinea 2789 (RNG). Lérida(?): Cerdagne, Estavar, 1230 m, 8 September 1929 (fr), Sennen s.n. (BM). Madrid: Madrid, Real Casa de Campo, June 1930 (fl), Martinez s.n. (BM, MA*). Avila: Hoyacasero, Río Alberche at Venta del Obispo, 1250 m, 14 July 1983 (fl), M. \& S. Gardner 2002 (BM, RNG).

PORTUGAL. Minho: [Braga] juxta Guimaraeus [Guimarāes] in Durminia [Minho?], n.d. (fl), Baron Paiva s.n. (K).

ITALY. Novara: Alpi Lepontine, Valle Formazzo, Altillone, 1300 m, 4 August 1912 (fl), Roggiani s.n. (BM).

SWITZERLAND. Ticino: Monte Generoso, 6 July 1856 (fl), Murray s.n. (BM). Valais: Brieg [Brig] to Viesch, 22 July 1881 (fl), Linton s.n. (BM). Vaud: near Vevey, 30 June 1856 (fl), Murray s.n. (BM).

AUSTRIA. Niederösterreich: Weinverteil, Hagenbrunn, zwischen Kronawettberg und Tradenberg, 23 June 1993 (bud), Vitek s.n. (BM). Steiermark: ad pagum Gösting prope urbem Graz, 460 m, September 1909 (fl \& fr), Reiter in Hayek, Fl. Stir. Exsicc. 1016 (BM). Tirol: Seefeld, 1200 m, 23 August 1936 (fl), Wyatt 77 (K).

GERMANY. Baden-Wurttemburg: Schwarzwald, Heselbach, 4 August 1931 (fl), Williams s.n. (BM). Hessen: Milseburg, 13 September 1913 (fl), Arnold s.n. (FR). Thuringen: Strasse Wilhelmstal-Etterwinden, 7 August 1948 (fl), Launert 166 (BM). Schleswig-Holstein: Forst Neumünster, 17 July 1969 (fl), Holm-Nielsen et al. in Fl. Germ. Exsicc. 16 (BM, TAI).

DENMARK. Jylland: Ajstrup, S. of Aarhus, 23 July 1965 (fl), Pedersen in Fl. Jutl. Exsicc 140 (BM, TAI). Sjaelland: Nordsjaelland, Tisvilde Hegn., 1913 (fl), Dahl D. 45b (BM).

NORWAY. Vestfold: Jahlsberg, Oslo Fjord, Aasgaardstrand, 10 September 1934 (fl), Williams s.n. (BM).

SWEDEN. Blekinge: Kellovik, Injauley, 191-(fl), F.G. Johansson s.n. (BM). Malmöhus: Malmö, July 1886(fl), G. Johansson s.n. (BM). Göteborg: Ringon, 23 July 1957 (l. fl), Blom s.n. (BM). Småland: Madesjö, 29 July 1909 (fr), Medelius s.n. (BM). Gotland: Visby, July 1912 (fl), E. Th. Fries s.n. (BM). Södermanland: Millsten, 8 August 1929 (fr), Asplund s.n. (BM). Uppsala: Söderby Karl, Brölunde, 12 July 1956 (fl), H. Smith 2037 (BM). Varmland?: par. Hilared, ad Tarsered, 12 July 1916 (fl), Ohlson s.n. (BM).

FINLAND. Uusimaa: Varsinais-Suomi, Korppoo, Jurmo, Huwudskär, 23 July 1965, Kause \& Seikkula s.n. (JE).

ESTONIA. Tartu: Dorpat bei Ropkoi, 25 July 1860 (e. fr), Gruner s.n. (BM).

BELORUS. Distr. Nowogródek [Novogrudsk], ad Niankow, 1893 (fl), Dybowski in Rehman \& Wolszczak, Fl. polon. exsicc. 148 (BM).

RUSSIA. St Petersburg?: Ingria, June-August 1860 (fl), Herb. Fl. Ingricae 134 (BM, K). The species is recorded by Gorschkova (1949: 249) from all regions, except Karelia-Lapland and the Arctic, east to AngaraSayan (Chuna Angara watershed). The precise areas of overlap between the distributions of subsp. perforatum and subsp. songaricum are uncertain but appear to be in the central Ukraine and the southern Altai (see Maps 6 and 9). The species (no doubt subsp. perforatum) has also been recorded from the Mongolian side of the Altai mountains (Gubanov, 1996: 76).

POLAND. Lublin: Lublin distr., 1 July 1884, Królestwa s.n. (JE). BielskoBiala: Wadowice, Wiepozk. Andrychowa (pr. Andrychóv), 18 July 1938 (fl), Lancucka in Pl. Pol. exsicc. 328 (BM, JE, K). Jelenia Góra: Sudetia, 
Hirschberg, Perle des Westens, 1 August 1958, Köhler \& Zippold s.n. (JE). Wabrzych?: Reichenstein [Złoty Stok], Dörndorf, 20 August 1899 (fl), Troedel s.n. (FR); Schweidnitz [Świdnica], Költschenberg, September 1882 (l. fl), Peck s.n. (FR).

CZECH REPUBLIC. Bohemia: prope vicum Prúhonice haud procul Pragam, c. 300 m, 22 August 1958 (1. fl \& fr), Nitka in Fl. Czech. Exsicc. I 48 (BM).

SLOVAKIA. BratislavskyKr.: N. Vratislava, 1803, Collector? s.n. (JE). HUNGARY. [Province?]: Gau Mayn?, August 1873 (fl), Leichterniss? s.n. (BM).

ROMANIA. Transylvania: [Carus Severin] Banat, N. of Turnu Severin, 24 km above Băile Herculane up Cerna valley, 27 July 1971 (fl), Frazer Jenkins 3499 (BM). Moldavia: Mun. Bacău, prope pagum Măgum, c. 400 m, 25 August 1971 (fl), D. Mititelu, Barabaşr \& L. Mititelu in Fl. Exsicc. Distr. Bacov. 351 (BM). Walachia: Oltenia, distr. Gorj, Cimpul Experimental Ciocirlău, 29 June 1965 (fl), Cirtu \& Zaharia in Fl. Olten. Exsicc. 960 (BM).

BULGARIA. Tolbukhin: Süddobrudscha, Kap Kaliskra, 16 August 1958 (fr), Meyer 645 (JE). Varna: Süddobrudscha, Varna, Weg vom Strande zum Aladsha Monastir, 11 August 1958 (fl \& fr), Meyer 414 (JE). Sliven: prope Sliven, in monte Sini Kamil, 20 June 1907 (fl), Schneider It. balc. 583 (BM). Yambol?: Strandsha-Planina, zwischen Blgari und Kosti, c. 300 m, 14 October 1958 (fr), Meyer 2088 (JE). Stara Zagora: Stara Planina, Krstec, zwischen Stara Zagora und Trnovo [Veliko Turnovo], 28 October 1958 (fl), Meyer 2234 (JE). Smolyan?: in Rhodope Centralis ad Selča-Djorlen, 12 July 1924 (fl), Stefanoff s.n. (BM) ['var. humile'].

SLOVENIA. Carniola, September 1854 (fl), Ball s.n. (K).

CROATIA. Dalmacija: Velebit Mts, 840 m, 2 July 1962 (fl), Mathew \& Pycraft 212 (BM).

SERBIA. Srbija: Vranja [Vranje], 1919 (fl), Tindal Lucas 104 (BM) [hybrid?]; circa urbem Gevlegi supra pagum Sermenin, Mt Rožin, 17 July 1937 (fl), Grebenchikoff s.n. (K). Kosovo: Bertiscus (Alpes boreales albanicae) in fauce rivuli Sušica prope oppidum Peč (Ipek), 750-950 m, (fl), K.H. Rechinger \& Scheffer Iter balc. 1933782 (K).

BOSNIA. Sarajevo, 750 m, 12 July 1960 (fl), McCallum Webster 4036 (K).

MONTENEGRO. Distr. Vasojavici, Korpice, 30 August 1903 (fl \& e. fr),
Hannibal in Baldacci Alb. X 44 (BM). Distr. Kuči, Poprat (Trijapsi), 4 July 1900 (fl), Baldacci Alb. VII 56 (BM, K).

ALBANIA. Patok, Mamuras, 6 m, 15 May 1936 (fl), Pennington 206 (K).

MAKEDONIJA. Šar Planina, 900-1200 m, 9 September 1968 (fl), Roper 9 (BM). Gostiver to Navrovo, $3 \mathrm{~km} \mathrm{NE}$ of top of pass, $1100 \mathrm{~m}$, 19 July 1970 (fl), Edmondson 227 (BM).

GREECE. Thraki: Thracia occid., in monte Karlik-Dagh prope Komotini (Gümüldschina), 1200 m, 2 July 1936 (fl), K.H. \& F. Rechinger Iter Graecum IV 10478 (BM). Makhedonia: N. Khalkidiki, Oros Cholomon, c. 8 km WSW of Arnaea, 1100 m, 10 September 1981 (fl \& fr), Husain, Jury \& Rutherford 99 (BM, RNG*) ['var. humile'].

TURKEY. Balikesir: Mt. Ida, prope Kareikos, 3 July 1883 (fl), Ascherson in Sintenis 474 (BM).

\section{INTRODUCTIONS}

CANADA. Newfoundland: fide Scoggan (1978: 1097). Prince Edward Island: Royalty Road, 9 August 1888 (fl), Macoun s.n. (BM). Nova Scotia: Bridgetown, 5 July 1872 (fl), Fowler s.n. (P). New Brunswick: Rothesay, 1 September 1875 (fl), Mathew s.n. (P). Quebec: Quebec, foot of Heights of Abraham, 13 August 1959 (fr), Stearn 2403 (BM); Co. Sherbrooke, Jouvence, 17 September 1976, Bourassa 43 (H). Ontario: Stanford Township, 10 August 1943 (fl), K.O. Wood s.n. (BM); Ottawa (West), Nurminutly, 15 July 1927, Pesola s.n. (H). Br. Columbia: W. Vancouver, corner 17th Street and Duchess Ave., 9 August 1963 (fl), Bird 9061 (BM); Vancouver I., Cowichan Lake Road, 171 m, 28 June 1967, Turner et al. 552 (H).

U.S.A. Maine: Marion Co., Marion, 28 August 1956 (fl), Rees 403 (BM). Vermont: Windham Co., Townshend, 10 July 1937 (fl), E. \& H. Moldenke 9893 (BM). New Hampshire: Rockingham Co., just S. of Portsmouth on US Rt. 1, 22 August 1967 (fr), Ahles 69436 (BM). Massachusetts: Hampshire Co., Northampton, off Daymon Rd., 19 July 1979 (fl \& fr), Ahles 87101 (BM). Rhode I.: Newport Co., Tiverton, Four Corners, 2 July 1979 (fl), Ahles 83182 (H). New York: Tompkins Co., Connecticut Hill, 7 September 1983 (fl), Kearney 39 (BM). New Jersey: Somerset Co., Watchung, 4 July 1934 (fl), Moldenke 8066 (BM, TAI). Pennsylvania: Westmoreland Co., c. $2.5 \mathrm{~km} \mathrm{~S}$. of Ligonier on PA hwy 711, 400 m, 1 July 1979 (fl), Utech 79-327 (BM, W). Maryland: Prince Georges Co., Beltsville, 8 July 1950 (fl), Petrak 314 (W).

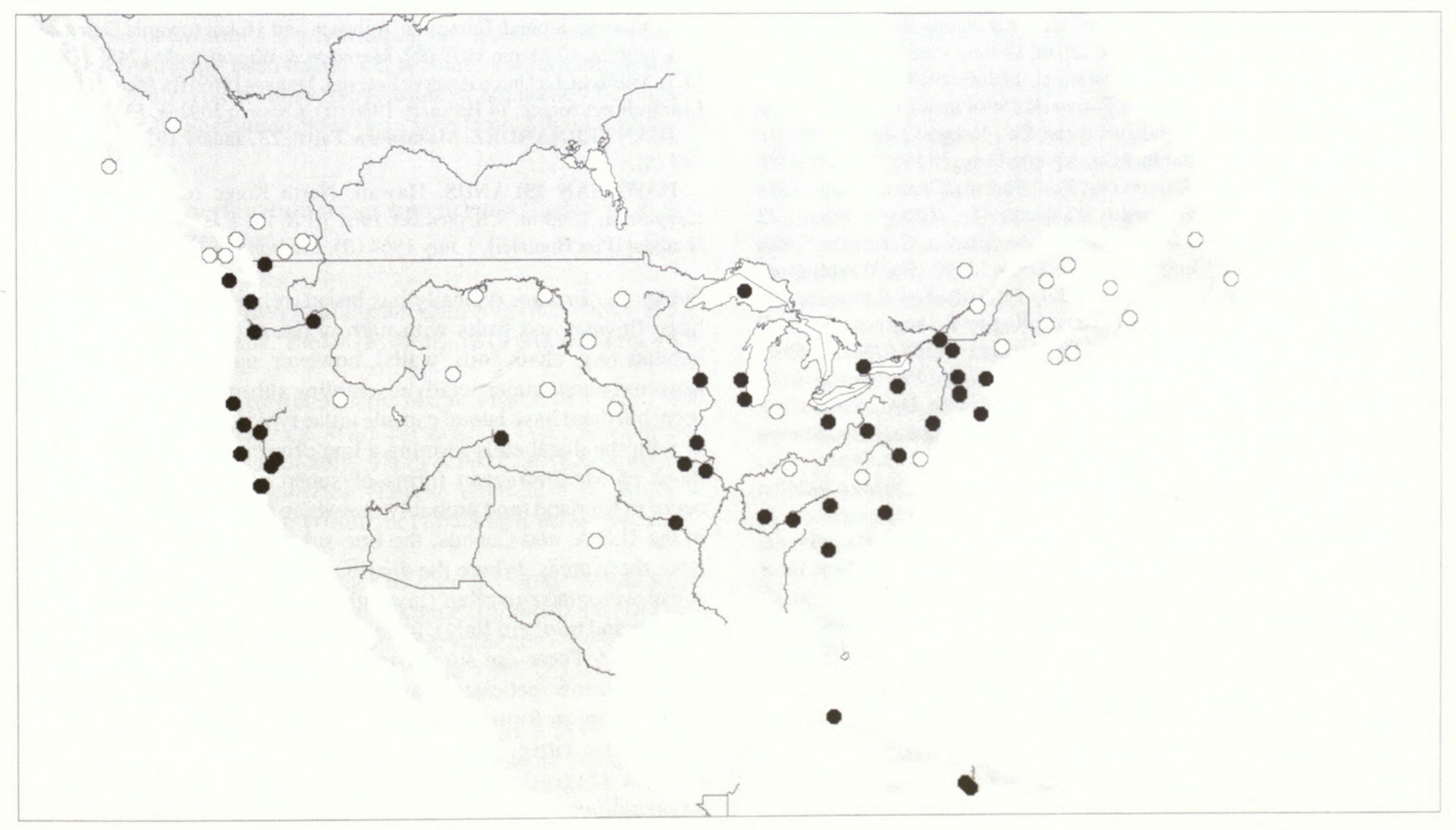




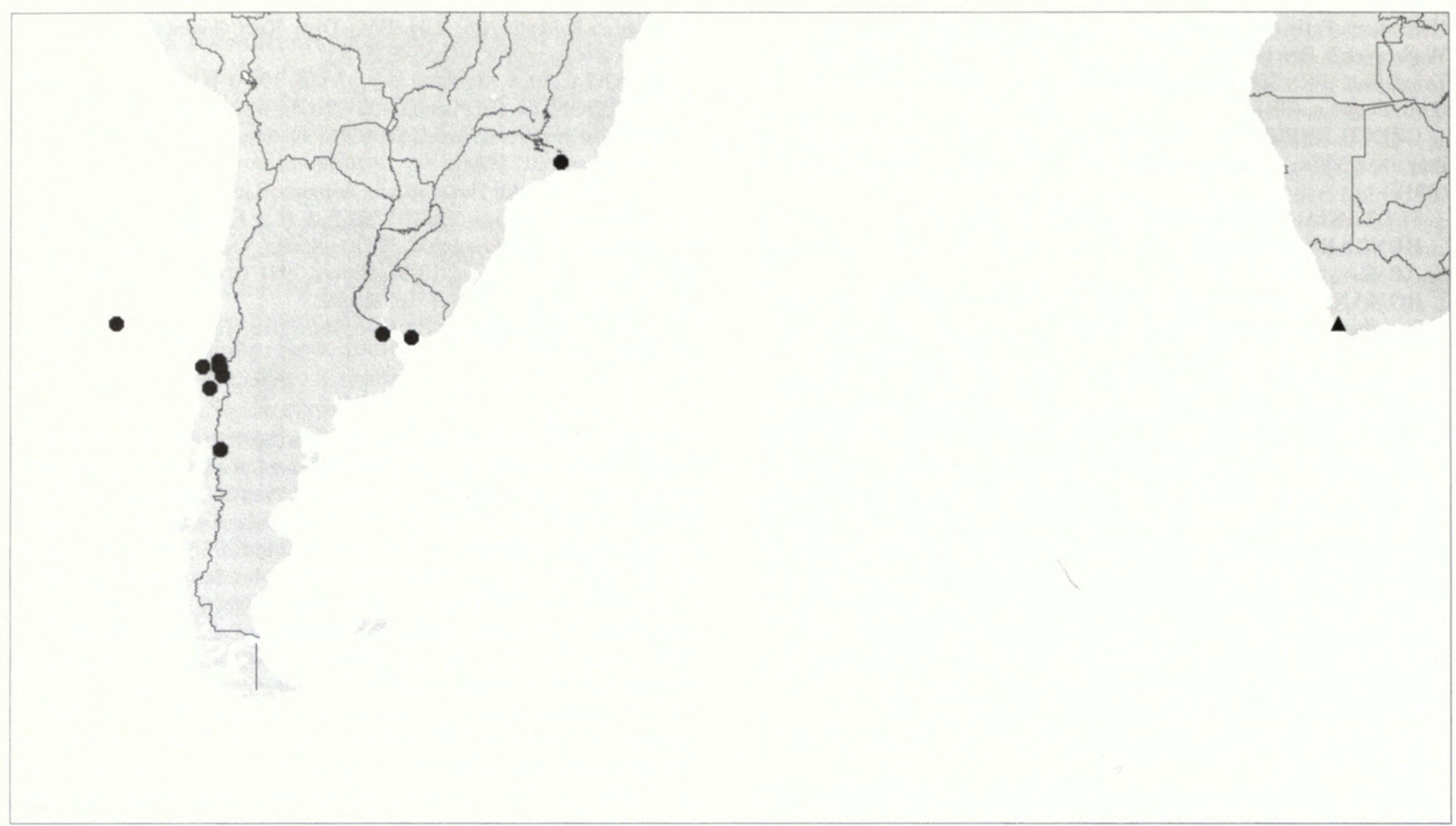

Map 8 5a. H. perforatum subsp. perforatum, South America (introduced)

Virginia: Giles Co., just off Va. 700, entrance to Mountain Lake Biol. Stn., 1146 m, 28 July 1968 (fl \& fr), Culwell s.n. (BM). N. Carolina: Avery Co., E. side of Grandfather Mountain, below summit, 1560 m, 21 July 1968 (fl), Culwell s.n. (BM). Tennessee: McMinn Co., Etowah, 20 July 1969 (fr), Rogers 43984 (H). Arkansas: Pope Co., US 64 at Happy Bend Rd., 6.7 km E. of junction with Ark. 105 in Atkins, 120 m, 12 June 1968 (fl), Culwell s.n. (BM). Missouri: Marion Co., near Hannibal, 13 July 1918 (fl), Davis 8969 (H). Illinois: Cork Co., E. from Des Plaines R., S. of Irving Park Rd., 4 July 1956 (fl), Bennett s.n. (W). Indiana: Lake Co., Roby, 12 July 1906 (fl), Lansing 2551 (W). Ohio: Trumbull Co., Vienna Twp., 25 July 1965 (fl \& fr), Sturm 160 (W). Michigan: Barago Co., Ford Forestry Center, 13 July 1974 (fl), Bourdo 28729 (W). Wisconsin: Waukesha Co., Bishop's Woods, 22 June 1970 (fl), Klopatek s.n. (H). Colorado: Boulder Co., S. Boulder Creek $9.6 \mathrm{~km} \mathrm{~S}$. of Boulder, 27 June 1967 (fl), Weber 13190 (H). Washington: Olympic Peninsula, Deer Park, 390 m, 17 July 1965 (fl), Fisk \& Chapman 97 (H). Oregon: Jackson Co., P.O. Prospect, Rogue R. bottoms, Farewell Forestry Camp, 780 m, 28 July 1959 (1. fl), Demaree 41365 (BM). California: Trinity Co., New River, Up Grade Mine, 10 August 1950, Wheeler 6774 (BM, RSA*). Also recorded from Connecticut, Delaware, D.C., S. Carolina, W. Virginia, Kentucky, Texas, Oklahoma, Kansas, Nebraska, Iowa, Minnesota, N. \& S. Dakota, Wyoming, Montana and Idaho (Robson, ined.).

MEXICO. Kbg., 1865 (fl), Bilimeck s.n. (MEXU). No precise locality, n.d. (fl), McMinn s.n. (P).

CUBA. Matanzas: Matanzas, December 1822 (fl \& fr), Poeppig s.n. (BM, P, W). Oriente: Sierra de Nipe, Woodfred, c. 500 m, 24 September 1922 (st), Ekman H.9313 (S).

HAITI. Massif de la Selle, Pétionville, c. 1400 m, 31 July 1924 (fr), Ekman H.1217 (S, US); above Port au Prince, 1600 m, 1947 (fl), HeldringTalma s.n. (U).

BRAZIL. Rio de Janeiro: Serra do Itataia, Retiro, 17 May 1902 (fl \& fr), Dusén 258 (S).

URUGUAY. Montevideo: Sayago, 15 February 1936 (fr), Rosengurtt B 2049 (GH).

ARGENTINA. Buenos Aires: Bella Vista, October 1915 (st), Hicken 444 (GH). Chubut: Lago Puelo, 10 February 1955 (fr), Burkhart 19915 (US).

CHILE. Talca: Empedrado, 11 March 1972 (fr), Mahu 8710 (H).
Concepción: Saltos del Laja, 5 January 1971 (fl), Lourteig 2518 (S). Nuble: Termas-Chillan, 8-10 km de las Termas, 2000 m, 7 January 1971 (fl), Lourteig 2535 (P, S). Bio Bio: Parlahueque, December 1929 (fl), Piria 197 (GH). Malleco: Manzanar, 13 January 1986 (e. fr), Pedersen 14214 (BM). Cautin: Dpto Victoria, around Termas de Tolhuaca and $16 \mathrm{~km}$ towards Curacuatin, 950-1180 m, 12 March 1939 (fr), Morrison \& Wagenknecht 17488 (GH, K, MO). Valdivia: La Union Reserva Forestal, January 1969 (fl), Mahu 9739(H). Llanquihue: Alerce, 14 February 1936 (fr), Cabrera 3691 (F, S).

JUAN FERNANDEZ. Masafuera: Papal, 23 January 1955 (fl), Kuschel 147 (S).

HAWAIIAN ISLANDS. Hawaii: North Kona, road up Huaalalni, Kaupulehu, 1500 m, 9 September 1961 (fl \& fr), Fosberg 42087 (BISH); Hualalai [Puu Hualalei], 1 July 1964 (fl), Carlson s.n. (BISH).

Subsp. perforatum typically has broad, relatively large leaves and large flowers and fruits with narrow linear oblique vittae. In dry habitats (e.g. chalk soils, walls), however, narrow-leaved smallerflowered plants superficially resembling subsp. veronense are often seen; but these have lateral capsule vittae typical of subsp. perforatum or with the distal ends forming a line of vesicles, not irregular like those of Mediterranean forms of subsp. veronense. Such plants occur in England (and probably elsewhere in NW Europe) as well as in the U.S.A. and Canada, the true subsp. veronense being absent from these areas. Where the distributions of subsp. perforatum and subsp. veronense overlap (in southern France, southern Germany, Austria and northern Italy), forms intermediate between the subspecies occur. These are similar to the northern dry-habitat forms in having narrow petiolate leaves, but the capsule glands are also intermediate in form, i.e. \pm irregularly vesiculate but with several dorsal linear vittae. Examples of such intermediate specimens from Austria (Styria) were cited by Fröhlich (1911) as subsp. angustifolium, e.g. Fölling bei Maria Trost, 23 July 1910 (fr), Fröhlich GZU16326 (GZU). There is evidence that such populations show cytological irregularities (Garbari, in litt.) 


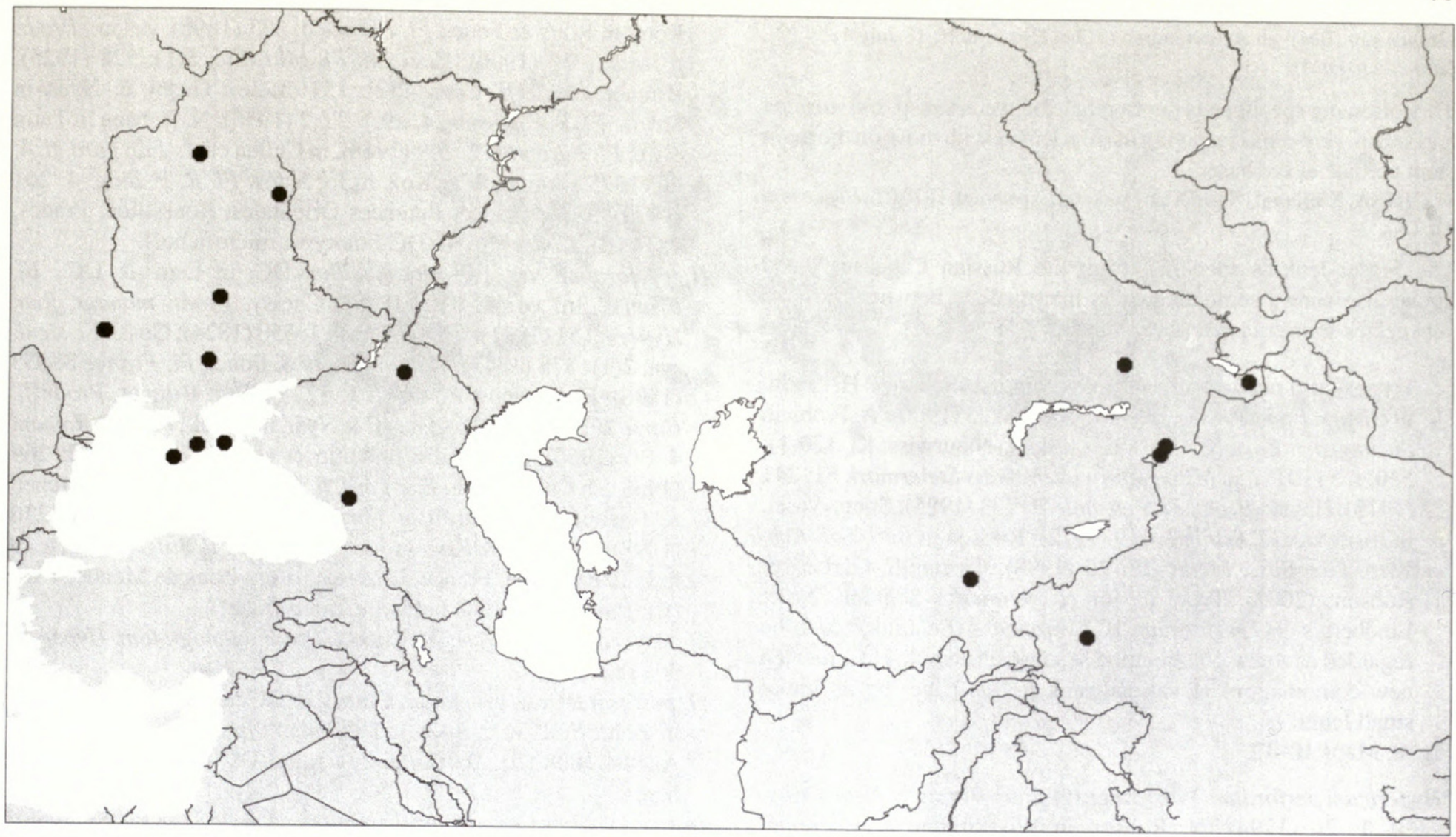

Map 9 5b. H. perforatum subsp. songaricum

It seems likely that subsp. perforatum was introduced into North America independently in the east and the west.

A low, erect to procumbent southern Balkan plant with small, rather broad leaves $(1: b=1-2.5)$ and capsule valves bearing lines of vesicles has been named $H$. perforatum var. humile Stranski, but no valid description has been traced. On account of intermediate forms that link it with typical subsp. perforatum, it apparently belongs to that subspecies. Specimens have been seen from Albania, Bulgaria and Greece.

5b. Hypericum perforatum subsp. songaricum (Ledeb. ex Rchb.) N. Robson, stat. nov.

Fig. 8, Map 9.

H. perforatum var. [ $\beta$ ] latiglandulosum Choisy in DC., Prodr. 1: 550 (1824). Type: Ukraine, Tanais [R. Don], 1819 (fl), Goldbach s.n. (G-DC!-holotype).

H. songaricum Ledeb. ex Rchb., Icon. bot. pl. crit. 3: 72, t. 283 f. 446 (1825); Spreng., Syst. veg. 4(2): 297 (1827). Type: Kazakhstan, 'ad lacum Noor-Saisan dictum', fl., Ledebour s.n. (LE-holotype).

H. perforatum var. songaricum (Ledeb. ex Rchb.) K. Koch in Linnaea 15: 714 (1841); Woron. in Kuzn., Woron. \& Fomin, Fl. Cauc. crit. 3(9): 56 (1906).

H. perforatum var. gracile Gruner in Bull. Soc. Imp. Naturalistes Moscou 41(3): 132 ( , 869). Type: Ukraine, Zaporozh'ye, ‘Gubern. Catherinoslav, in demissis ad Borysthenem infra urbem Alexandrowsk' [Zaporozh'ye], 20 June 1865 (fl), Gruner s.n. (BM!-holotype?).

H. komarovii Gorschk. in Bot. Žurn. SSSR 24: 428, f. 1 (1939). Type: Kirghizstan [Kirghizia], in monte Arslanbob supra Namas-tasch, 23 August 1925 (fl), Massagetov 335 (LE-holotype).

Icon: Rchb., Icon. bot. pl. crit. 3: t. 283 f. 446 (1824).

Leaves sessile (at least on main stems); lamina 6-15 $\times 2-10 \mathrm{~mm}$, oblong to oblong-ovate $(l: b=2.5-4)$, base \pm shallowly cordateamplexicaul, often glaucous beneath. Inflorescence not congested, with branches relatively short, straight. Petals with laminar glands all pale. Capsule valves with lateral vittae linear, narrow or slightly swollen but rarely interrupted.

Northern Kazakhstan and adjacent Kyrgyzstan and China (NW Xinjiang), south-eastern Russia and the Ukraine (including Krym).

CHINA. Xinjiang: Altay Xian, 1100 m, 18 August 1956 (fl \& fr), Ching 2434 (CDBI, IBSC); Huocheng [Suiding] Xian, 1500 m, 22 June 1965 (fl), Cheo et al. 650862 (IBSC, KUN, NAS).

KAZAKHSTAN. Almatinskaya Obl.: Songaria, in dumetis montium Alatau, n.d. (fl), Schrenk s.n. (K, LE*); Semiryechensk prov., Vyernyi distr., Zaylinskiy (Trans-Ilian) Alatau, 14 July 1907 (fl), Sokalsky 118 (BM). Zapadnyy-Kazakhstan Obl.: Chingirlauskiy rayon, Kara-Alag, 16 July 1935 (e. fr), Akastovy(?) s.n. (A*, BM, LE).

KYRGYZSTAN. *Osh: in monte Arslanbob [Pik Skobeleva] supra Namas-tasch, 23 August 1925 (fl), Massagetov 335 (LE).

RUSSIA. Astrakhanskaya Obl.: Sarepta, 16 June 1879 (fl), Becker s.n. (BM). Stavropolskiy Kray: S. of Karachayevsk, near Gora Dembay Ul'gen, 11 July 1971 (fl), Fraser Jenkins 3219 (BM).

UKRAINE. Orlovskaya Obl.: Prov. Orel, circut. Felitz, inter Polna et pag. Morskaja, 20 June 1868 (bud), Gruner s.n. (BM). Dnipropetrovskaya Obl.: Gubern. Catherinoslav [Dnipropetrovs' $k$ ], in demissis ad Borysthenum [Dnieper] infra urbem Alexandrowsk [Zaporozhye], 20 June 1865 (fl), Gruner s.n. (BM). Krym: prope Karasubazar [Belogorsk, Bilohirs'k], 23 June 1900 (fl), Callier 564 (BM, FR, JE, K); in aprices Tauriae montosae, n.d. (fl), Pallas s.n. (BM).

Some Crimean specimens lack the cordate leaf base of this subspecies but are otherwise clearly a reduced form of it. The following specimens are intermediate between subsp. songaricum and subsp. perforatum in having the leaves on the main stem sessile but those on branches petiolulate:

UKRAINE. Cherkasky Obl.: Uman, Farco, June 1867 (fl), Golde s.n. (BM, K). ? Obl.: Valka, zwischen Veselaya und Zingalni (?), 5 May 1865 (fl), 
Gruner s.n. (BM); an Ackerrändran (?) bei Condo-dorf, 18 July 1859 (fl), Gruner s.n. (BM).

The following specimen is intermediate between subsp. songaricum and subsp. veronense in having narrow leaves with those on the main stem cordate at the base.

CHINA. Xinjiang: [Kashi Xian] Yarkand Expedition, 1870 (fl), Henderson s.n. $(\mathrm{K})$.

The Fraser-Jenkins specimen from the Russian Caucasus listed above also shows some characters intermediate between those of subspecies songaricum and veronense.

5c. Hypericum perforatum subsp. veronense (Schrank) H. Lindb. in Öfvers. Förh. Finska Vetensk.-Soc. 48: 73 (1906); A. Fröhl. in Sitzungsber. Kaiserl. Akad. Wiss., Math.-Naturwiss. Kl. 120(1): 530, f. 5 (1911), in Mitt. Naturwiss. Vereins Steiermark 51: 241 (1915); Hayek, Prodr. Fl. Pen. balc. 1: 533 (1925); Stjep.-Vesel. in Josifović, Fl. Srbije 3: 119 (1972); Robson in Bull. Soc. Ech. Vasc. Eur. Bass. Médit. 27: 20 (1998), Ciccarelli, Garbari \& Robson, (2002). Type: as for $H$. veronense Schrank. Note: Lindberg's ' $H$. perforatum L. *Veronense (Schrank)' is to be regarded as a new combination at subspecies rank. He indicated new combinations at varietal rank in this paper by an initial small letter.

Fig. 8, Maps 10-12.

?Hypericum perforatum [var.] angustifolium Borkh. in Neues Mag. Bot. 1: 26 (1794); N. Robson in Wisskirchen \& Haeupler, Standardliste Farn- u. Blütenpfl. Deutschl.: 270 (1998). Type: Germany, not stated. The varietal epithet angustifolium has previously always been attributed to De Candolle, but Borkhausen's $H$. perforatum angustifolium has priority. By the date of his publication, a trinomial is assumed to be a variety. Borkhausen's type, however, is unknown (Stafleu \& Mennega, 1993: 340); and so whether his plant belongs to the narrow-leaved Mediterranean form with vesicular capsule glands (var. angustifolium DC.) or a narrow-leaved form of var. perforatum (with vittate, not vesicular capsule valves) cannot be ascertained. In either case De Candolle's var. angustifolium is a later homonym. However, as the variation between narrow-leaved plants with large and small leaves in the Mediterranean region is continuous, allowing the recognition of no more than one taxon, De Candolle's epithet microphyllum is available for it as a variety.

H. veronense Schrank in Neues Bot. Taschenb. Anfänger Wiss. Apothekerkunst 22: 95 (1811); Link, Enum. hort. berol. alt. 2: 276 (1821); Jord. in Schultz \& Billot, Annots Fl. France \& Allemagne: 49 (1855); Engl. in Verh. bot. Vereins Brandenburg 12: 49 (1870); O. Schwarz in Drudea 5: 61 (1965). Type: Italy, Verona, an den ehemaligen Sitzen des Amphiteaters zu Verona, October 1808 (fr), Schrank (not found). Neither Professor Garbari (Univ. of Pisa; in litt.) nor I have been able to locate type material of this 'species', which, according to Prof. Garbari, does not grow now at the type locality. (Schrank himself refers to strenuous efforts to extirpate it, even at that time.) There is no doubt, however, that Schrank's plants belonged to the narrow-leaved Mediterranean subspecies, even though the plants that he grew from their seeds were somewhat larger with leaves (some or all?) shortly petiolate. In the absence of type material, a neotype is therefore required: Italy, Verona, Anfiteatro di Verona, August 1874, Cesati s.n. (RO!-neotype, Ciccarelli, Garbari \& Robson, 2002, ined.).

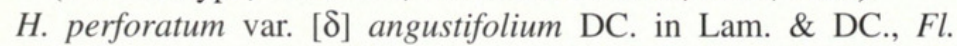
France, 3rd ed. 5: 630 (1815); Gaudin, Fl. helv. 4: 628 (1829); W. Koch, Syn. fl. germ. helv.: 134 (1835), in Röhling, Deutschl. Fl., 3rd ed. 5: 349 (1839); Beck, Fl. Nieder-Österreich: 530 (1892);
Rouy in Rouy \& Fouc., Fl. France 3: 333 (1896); Zelen., Prodr. fl. Taur: 233 (1906); Hegi, Ill. Fl. Mitt.-Eur. 5(1): 528 (1925); Briquet, Prodr. fl. Corse 2(2): 151 (1936); Guşul. \& Nyár. in Sävul., Fl. R. P. Roman. 4: 29, t. 2 f. 2 (1956); N. Robson in Tutin et al., Fl. Europaea 2: 269 (1968), in Cullen et al., Eur. gard. fl. 4: 60 (1995); Jordanov \& Kož. in Jordanov, Fl. R. P. Bulg. 4: 261 (1970). Type: France, Pyrenées Orientales, Roussillon, Prades, 1814 (fl), Coder s.n. (G-DC-holotype, microfiche!).

$H$. perforatum var. [E] microphyllum DC. in Lam. \& DC., Fl. France, 3rd ed. 5: 630 (1815); Choisy, Prodr. monogr. fam. Hypéric.: 51 (1821). in DC., Prodr. 1: 550 (1824); Guss., Fl. sicul. syn. 2(1): 378 (1843); Rouy in Rouy \& Fouc., Fl. France 3: 333 (1896); Fiori, Nuov. Fl. Italia 1: 522 (1924); Briquet, Prodr. fl. Corse 2(2): 151 (1936); Guşul. \& Nyár. in Săvul., Fl. R. P. Roman. 4: 30 (1956); N. Robson in Tutin et al., Fl. Europaea 2: 269 (1968), in Cullen et al., Eur. gard. fl. 4: 60 (1995), in Wisskirchen \& Haeupler, Standardliste Farn- u. Blütenpfl. Deutschl.: 270 (1998); Jordanov \& Kož. in Jordanov, Fl. R. P. Bulg. 4: 261, t. 49 f. 3 (1970). Type: France, Lozère, aux environs de Mende, 1810 (fl), Prost s.n. (G-DC-holotype, microfiche!).

H. perforatum var. $[\gamma]$ sensu Choisy, Prodr. monogr. fam. Hypéric.: 50 (1821).

H. perforatum var. [ $\gamma]$ elatum Choisy in DC., Prodr. 1: 550 (1824), in Zoll., Syst. Verz. 1-2: 151 (1854). Type: Italy, Florence, 10 August 1808 (fl), De Candolle s.n. (G-DC!-lectotype, selected here).

H. stenophyllum Opiz, Naturalientausch no. 9: 158(1825). Syntypes: Czech Republic, 'in Böheim', Opiz s.n. (PR-syntype); Austria, 'in Oberösterreich', Brittinger s.n. (PR-syntype). A specimen from the Czech Republic, Hodkovicka [Prague], 25 July 1850 (fr), Opiz (PR!), labelled 'Hypericum stenophyllum Opiz' by Opiz himself, is subsp. veronense and, in the apparent absence of the syntypes, can be taken as a representative specimen of his species.

H. perforatum var. nanum Gaudin, Fl. helv. 4: 627 (1829). Type: not stated. 'An $H$. perforatum $\beta$ microphyllum Dec. Fl. Fr. Suppl. p. 630?' (LAU-holotype).

H. perforatum var. veronense (Schrank) Ces. in Cattaneo, Not. Nat. Civ. Lombardia: 291 (1844); Beck, Fl. Nieder-Österreich 2: 530 (1892); R. Keller ex Albov in Trudy Tiflissk. Bot. Sada 1: 4 (1895); Béguinot in Fiori, Béguinot \& Pampini, Flora Italica Exsiccata, no. 817 (1904); Woron. in Kuzn., Busch \& Fomin, Fl. Cauc. Crit. 3(9): 56 (1906); Hegi, Ill. Fl. Mitt.-Eur. 5(1): 528 (1925); Grossg., Fl. Kavk., 2nd ed. 6: 54, 175 (1962). Soldano (1991: 248) claimed that Cesati made a comb. nov. at the rank of subspecies; but there would seem to be no justification for interpreting 'Hypericum perforatum L. $\beta$ veronense Schrnk.' as other than a variety. He certainly did not make the combination $H$. perforatum subsp. angustifolium (DC.) Cesati attributed to him by Gamisans \& Jeanmonod (1993: 183). See Robson \& Lambinon (2000). Béguinot's combination was made independently.

H. perforatum var. stenophyllum (Opiz) Wimm. \& Grab., Fl. Siles. 2(2): 82 (1829); Neilr., Fl. Nieder-Oesterr: 826 (1859).

H. schlosseri Heuff. in Flora 36: 626 (1853); Schlosser \& Vokut., Fl. croat.: 381 (1869); A. Fröhl. in Sitzungsber. Kaiserl. Akad. Wiss., Math.-Naturwiss. Kl. 120(1): 537 (1911) in adnot. Type: Croatia, in rupibus Zagoniae, Schlosser s.n. (W?).

H. microphyllum Jord. in F. Schulz, Arch. fl. France Allem.: 341 (1854). Type: France, Rhône, environs de Lyon, Jordan s.n. (LYholotype; BM!-isotype).

H. chrysostictum Webb, Fragm. fl. aethiop.-aegypt.: 54 (1854). Type: [Saudi Arabia?; not recorded from Ethiopia] 'Occurrit in herb. Figariano sine loci natalis indicatione.' (FI!-holotype). 


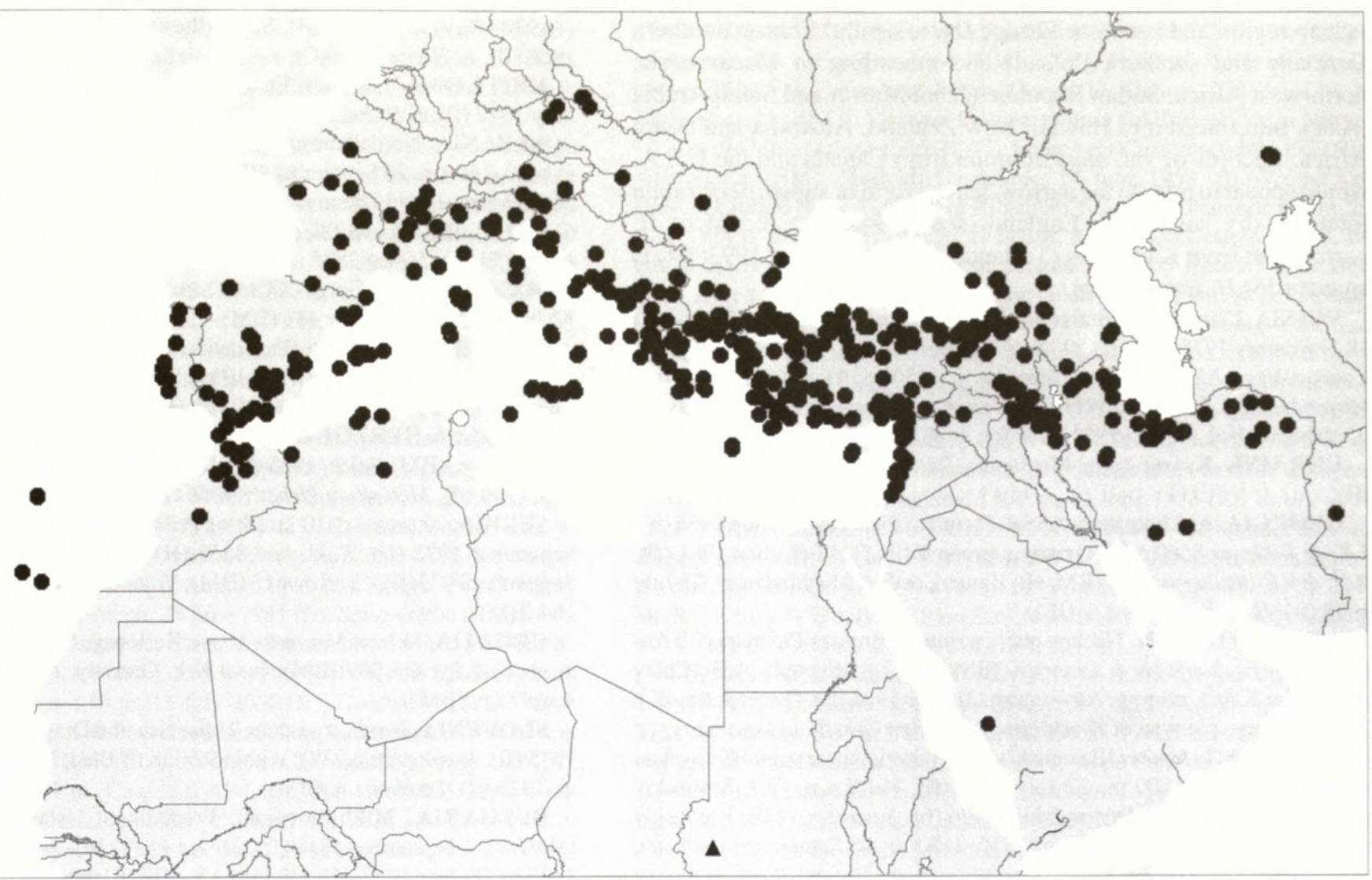

Map 10 5c. H. perforatum subsp. veronense, Mediterranean and S. Europe

, other records $\bigcirc$, introductions $\boldsymbol{\Lambda}$. Reported from south Germany.

H. aetnaeum Tornab., Fl. sicul.: 171 (1887), Fl. aetnea 1: 213 (1889). Type: Sicily, Mt. Etna, 'in elatis arenosis et ad nemora', Nicolosi s.n. (CAT-holotype).

H. nö̈anum Boiss., Fl. orient., Suppl.: 130 (1888). Type: Bulgaria, Rumelia, 'Hab. in monte Haemo minore Thraciae' [Iztochni Rodopi], Noé s.n. (G!-holotype).

H. perforatum var. $[\gamma]$ angustifolium subvar. lineolatum Rouy in Rouy \& Fouc., Fl. France 3: 333 (1896). Type: France, Cher, Mehun, Sables de Beauvoir, 3 July 1840 (fl), Déséglise in Billot exsicc. no. 3349 (P?-holotype; BM!, JE!-isotypes).

$H$. perforatum var. [ $\delta]$ mediterraneanum Rouy in Rouy \& Fouc., $F l$. France 3: 333 (1896). Type: France?, not stated.

H. perforatum var. typicum forma microphyllum (DC.) Fiori in Fiori \& Paol., Fl. Italia 1: 388 (1898).

H. perforatum var. ellipticum Freyn in Bull. Herb. Boissier II, 3: 1064 (1903), non Durand \& Pittier (1881). Type: Turkmenistan, Aschabad, in monte Ak-tepe, 17 June 1900 (1. fl), Sintenis 564a (G-lectotype, selected here; BM!, K!-isolectotypes); prope Suluklu ad fines Persiae, 4 September 1900 (1. fl), Sintenis 564b (Gsyntype; JE!).

H. perforatum var. moesicum Velen. in Sitzungsber. Königl. Böhm. Ges. Wiss. Prag 1903(28): 2 (1904), op. cit. 1910(8): 3 (1911); A. Fröhl. in Sitzungsber. Kaiserl. Akad. Wiss., Math.-Naturwiss. Kl. 120(1): 538 (1911) in synon. Type: Bulgaria, in Sredna Gora ad Adžar [Svezhen], 1902 (fl), Střibrny s.n. (W?).

$H$. perforatum var. collinum Woron. in Kuzn., Busch \& Fomin, Fl. Cauc. Crit. 3(9): 55 (1906); Grossg., Fl. Kavk. 2nd ed. 6: 55, 175 (1982). Type: Georgia, Sukhumi, no sklonam' gori Cherniyavskago, June 1904, Woronow s.n. (LE-lectotype, selected here).

H. perforatum var. corioides Vokut., nomen in scheda (WU); A. Fröhl. in Sitzungsber. Kaiserl. Akad. Wiss., Math.-Naturwiss. Kl. 120(1): 538 (1911), in synon.

H. perforatum subsp. angustifolium (DC.) A. Fröhl. in Sitzungsber.
Kaiserl. Akad. Wiss., Math.-Naturwiss. Kl. 120(1): 534, f. 6 (1911), in Mitt. Naturwiss. Vereins Steiermark 51: 241 (1915); Hayek, Prodr. Fl. Pen. balc. 1: 533 (1925); Stjep.-Vesel. in Fl. Srbije 3: 119 (1972); A. Ramos in Castroviejo et al., Fl. Iberica 3: 165, t. 45 ff. a-e (1989).

H. perforatum var. floribundum Sennen, ined.? 'Type': Spain, Barcelona, S. Celloni, 20 July 1922 (fl), Sennen 4864 (BC, BM!).

H. nachitschevanicum Grossh. in Izv. Azerbajdžansk. Fil., no. 1: 46 (1941), Fl. Kavk., 2nd ed. 6: 171, karta 195 (1962). Type: Azerbaijan, Nakhitchevan, inter pp. Urmys et Pazmara, 21 August 1933 (fl \& fr), Karjagin \& Isaev s.n. (BAK-holotype; LE!-isotype; BM!, K!-photographs).

$H$. perforatum var. longicapsulum Jordanov \& Kož in Jordanov, Fl. R. P. Bulg. 4: 261, 709, t. 49 f. 4 (1970) 'longicapsula'. Type: Bulgaria, Mt. Vitoša [Cherni Vrükh], in pratis prope refugium 'Pogledec', loco dicto 'Kārkāma', 1600 m, 18 September 1967 (fr), N. Vihodčevsky (SO-holotype).

Icones: Valdés, Talavera \& Galiano, Fl. Andalucía Occid. 1: 315 (1987); Castroviejo et al., Fl. Iberica 3: t. 45, ff. a-e (1993).

Leaves usually sessile (at least on main stems); lamina 9-20 × 1-4 $\mathrm{mm}$, usually linear $(\mathrm{l}: \mathrm{b}=5-9)$ but sometimes narrowly triangularlanceolate or linear-oblong $(1: b=2.5-4)$, or occasionally broadly ovate to elliptic or obovate, but then small (c. 5-10 $\times 4-5 \mathrm{~mm})$, base cuneate, paler but not glaucous beneath. Inflorescence occasionally congested, with branches relatively short, straight or curved-ascending. Petals with laminar glands all pale or rarely mostly black. Capsule valves with lateral vittae swollen at base (but not forming a regular distal row) or \pm interrupted to punctiform and wholly swollen (vesicular).

Southern Russia, the Ukraine (Krym) and the Caucasus region east to Kazakhstan and N. India (Uttar Pradesh) and west to the Mediter- 
ranean region and southern Europe (N. to central France, southern Germany and southern Poland) and extending to Macaronesia, north-west Africa, Sudan Republic (Jebel Marra) and Saudi Arabia (Asir). Introduced into Hawaii, New Zealand, Australia and South Africa. Records of var. angustifolium from Canada and the U.S.A. would appear to refer to the narrow-leaved form of subsp. perforatum found in dry habitats in England (see p. 94). The record of $H$. perforatum from Karpathos (Turland, Chilton \& Press, 1993: 94) is an error for $H$. tetrapterum.

RUSSIA. Ciscaucasia: Stavropolskiy Kray, N. of Pyatigorsk, Mt Mashuk, 18 November 1975 (fl \& fr). O. \& J. Degener 33,789 (NY); KarachayevoCherkesskaya ASSR, südlich Teberda, c. 1350 m, 11 August 1957 (fr), Meyer, Lippold \& Kohler 257 (JE); Severo-Osetinskaya ASSR, Vladikavkas [Ordzhonikidze], August 1981 (fl \& fr), A. \& V. Brotherus 192 (BM, H).

UKRAINE. Krym: Yalta, Massandra, 22 June 1969 (fl), Rintanen s.n. (H).

GEORGIA. Abkhazskaya ASSR: Pizunda [Pitsunda], 19 July 1966 (fr), F.K. \& J. Meyer 8560 (JE). Gruziya: prope Tiflis [Tbilisi], June 1981 (fl), A.H. \& V.F. Brotherus 192a (BM, H); Batumi, östlich Machindžauri, 25 July 1978 (fr), H. \& R. Manitz s.n. (JE).

AZERBAYDZHAN. Nachrespublica, inter Urmys et Paxmara, $21 \mathrm{Au}-$ gust 1933 (fr), Karjagin \& Isaev s.n. (BM and K photographs, LE); Chizy distr. (olim Kuba), prope p. Alty-agatsh, 21 June 1935 (fl), Gurvitsh s.n. (K); Nakhichevan - see type of $H$. nachitschevanicum Grossh. in synonymy.

ARMENIA. In montes 'Bazumski khrebet' in vicinitate oppidi Kirovakan (Karalkisa), 1600-1800 m, 22 July 1975 (fl), Vašák s.n. (W); Sevanskiy raion, Goranrotuv n.-o. Sevan, 6 July 1926 (fr), Savur s.n. (LE); Kafanskiy raion, gor. Kadzharan, Tandzasar, 1850-2150 m, 16 September 1966 (fr), Manakian s.n. (BM)

TURKEY. Kars: Ardahan, Gürçayir village, 31 July 1976 (fl), Sanda 1196 (BM). Bitlis: Corgih to Bitlis, 2250 m, 31 July 1976, Tong 207 (E). Hakkari: Cilo Dağ, in Diz deresi above Kursi, 1890 m, 7 August 1954 (fr), Davis \& Polunin D. 23962 (BM, E, K). Çoruh: Borça to Hopa, 300 m, 22 June 1957 (fl), Davis \& Hedge D. 29882 (BM, E, K). Erzurum: Palandökea Dağ, 25 km from Çat to Erzurum, 2350 m, 27 July 1966 (fl), Davis 47385 (E). Trabzon: Höhe südlich Trabzon, 250 m, 26 June 1931 Görz 654 (BM). Amasya: Erbaa to Kozlu, 550 m, 5 June 1967 (fl), Tobey 2190 (E). Malatya: 5 km NW Darende, 1200 m, 8 September 1977 (FL), Sorger 77-105-22 (WU). Hatay: Hassa, Tüyek village, 9 July 1974 (fl), E. Sezik 680 (BM). Nevşehir: Göreme, $c .10$ km W. of Urgüp, c. 1000 m, 3 August 1956 (fl), NcNeill 399 (E, K). Içel: Bulgar Dagh, 'Gullek Boghas', 1140 m, 23 August 1853 (fl \& fr), Kotschy 282a (G). Kastamonu: Daday to Azdavay, 30 km, 1100 m, 30 July 1962 (fl \& fr), Coode \& Yaltirik D. 38658 (E, K). Ankara: Elma Dagh bei Ankara, c. 1600 m, 25 June 1932 (fl), Kotte 317 (K). Antalya: Manavgat, 4 June 1973 (fl), Himmetöglu H17 (BM, BAS*). Bolu: Ala Dağ distr., Kartal Kaya (Mt.), 2000 m, 11 August 1960 (fl), Khan, Prance \& Ratcliffe 490 (E). Eskişehir: Eskishehir, 500 m, 27 May 1971 (fl), Price 638 (K). Isparta: Eğridir distr., Barla Dağ foothills, 1200 m, 1 August 1960 (fl), Khan, Prance \& Ratcliffe 4219 (E, K). Istanbul: Alaton, 28 July 1967 (fl), Baytop \& Atila 11585 (E, ISTE*). Kütahya: Gediz, 850 m, 7 July 1962 (fl), Davis \& Coode D. 36969 (E, K). Burdur: Yeşilova to Denizli, c. 6.5 km, by Salda Golu, 1100 m, 1 June 1962 (fl), Dudley D. 35303 (E, K). Kirklareli: Demirköy, 19 July 1959 (fl), Baytop 5488 (BM). Izmir: Selçuk, Ephesus, 31 May 1972 (fl), E. \& G. Sezik 260 (BM, HUB*). Muğla: Marmaris, c. 4 km E. of Marmaris, s.l., 18 May 1983 (fl), Murto 1376 (H).

GREECE. Thasos: Glifada, 18 May 1986 (fl), Raitraluna? s.n. (C). Thraki: Nom. Xanthis, NE of village Dimarion, c. $26 \mathrm{~km} \mathrm{~N}$. of Xanthi, 550 m, 28 July 1977 (fr), Strid \& Georgiadhou 13485 (C). Makedhonia (E): [Nom. Kavala] c. 4 km W. of Kavalla, 11-12 July 1970 (fr), K.H. Rechinger 38260 (W). Makedhonia (W): Nom. \& Ep. Grevenon, Mt. Smolikas, 2-3 km S. of Samarina towards Armata, 1275-1350 m, 27 August 1975 (fl), Hartwig \& Seberg 4814 (C). Epirus: Distr. Janina, ad Paleochori Syrakou, 2 August 1895 (e. fr), Baldacci III 304 (BM). Ionian Is.: Korfu, S. of Korfu town, Kanoni, 20 May 1978 (bud), A. Hansen 441 (C). Thessalia: prov. Trikala, distr. Kalambaka, Meteora, between Ajia Triada and St. Roussanis, 600 m, 17 June 1977 (fl), Stearn A.64 (BM). Sterea Ellás: Graviá, 480 m, 20 June 1937 (f1), Balls \& Gourlay B. 3352 (BM). Peloponnisos: Prov. Achaia, Distr. Kalavrita, Mt. Helmos, lower SE slopes, 3 km W. of village Feneos, 10001200 m, 30 July 1980 (fr), Baden \& Franzén 684 (C). Evvoia: Mt. Dirphys, c. 1930 (fl), Guiol s.n. (BM). Sporadhes: Rhodos, S. of Kremasti, 9 May 1966 (fl), A. Hansen s.n. (C).

KRITI. Distr. Kissamos, Enneachoria, inter Myli et Elos, c. 100 m, 30 May 1942 (fl), K.H. Rechinger Iter Graecum VI 13437 (BM, K).

ALBANIA. Nordalbanische Alpen (Prokletija), Tethi, Shtegu i Dhenve, c. 1400-1600 m, 26 September 1961 (fl \& fr), Meyer 6427 (BM, JE); Korca, Mali i Moravës, bei Drenova, 1100-1200 m, 12 September 1962 (fr), Meyer 6141 (BM, JE); Viossa-Tal, an der Landstrasse nördlich Perati, c. 300 m, 10 July 1959 (fr), Meyer 3835 (JE).

MAKEDONIJA. Gorge of Crni Drim near Lukovo, N. of Struga, 650 m, 12 June 1971 (fl), Chater 432 (BM).

MONTENEGRO. Distr. Vasojaviči, Murino, 1 September 1903 (fl \& e. fr), Baldacci Iter Alb. X 46 (BM); $10 \mathrm{~km} \mathrm{S.} \mathrm{of} \mathrm{Titograd} \mathrm{[Podgorica],} 50 \mathrm{~m}, 20$ June 1965 (fl \& e. fr), Wrigley 65/1360 (K).

BOSNIA \& HERZOGOVINA. Velež planina, 1500 m, 6 July 1912 (fl), Sagorski s.n. (BM); Jajce, 1925 (fl), Leathes s.n. (BM); Sarajevo, 750 m, 12 July 1960 (fl), McCallum Webster 4036 (K).

SERBIA. Kosovo, c. $10 \mathrm{~km} \mathrm{~S}$. of Priština towards Uroševac, $600 \mathrm{~m}, 9$ September 1972 (fr), Kukkonen 8565 (H); Šavac-Pomoravlje, Damin, 13 September 1979 (fl), Cvetkovic 15 (BM); Vranja, 1919 (fl \& fr), Tindall Lucas 104 (BM).

CROATIA. Velebit Mts, pass above Karlobag, 690 m, 17 July 1962 (fl), Mathew \& Pycraft 339 (BM); Insel Krk, Omišaly, 17 July 1931 (fl \& fr), Hutel? s.n. (BM).

SLOVENIA. Istrien, zwischen Tulisevica und Draga di Lovrana, 23 June 1935 (fl), Ronniger s.n. (W); within $9.5 \mathrm{~km}$ of Bled, Mt. Triglav, 300-1200 m, 1923 (fl), Leathes s.n. (BM).

BULGARIA. Mikhailovgrad: Predbalkan, Ostabhang des Midshur [Midžor], 4 September 1958 (fr), Meyer 1171 (JE). Sofiya: Mt. Vitosha, c. 1400 m, 26 July 1952, Vihodčevsky s.n. (JE). Blagoevgrad: Struma-Tal, bei Marikostinovo, 23 September 1958 (fr), Meyer 1500 (JE). Plovdiv: in valle Akdere [Tundzha] prope Kalofer, 11 August 1893 (fr), Wagner 26 (BM, W*).

ROMANIA. Transylvania: Cluj, Turda Gorge, 23 July 1963 (fl), Dandy 1425 (BM). Dobrogea: Constanţa, Tekirg Cirol [Techirghiol], n.d. (fl), Cretzoiu s.n. (K).

HUNGARY. Pest: Pass between Doroy and Pilisovorosvar on Budapest road, 7 July 1962 (fl), Curle 44 (BM).

SLOVAKIA. Vrchol Sitna, c. 1000 m, 1957, Hostička \& Zelený (PRC*), only locality (fide Zelený, Jasičková \& Zahradníková, 1982: 310).

CZECH REPUBLIC. Possibly occurs (fide Čelakovský, 1875: 521).

POLAND. Wałbrzych: Silesia, Schweidnitz [Swidnica], Költschenberg, September 1882 (1. fr), Peck s.n. (FR).

GERMANY. Thüringen: Gera, Jena, Lichtenhain am Bahndamm, 20 June 1950 (fl), Launert 269 (BM) (verg. ad subsp. perforatum?). BadenWurttemburg: Istein in Baden, July 1919 ( $\mathrm{fl} \& \mathrm{fr}$ ), Meebold s.n. (K).

AUSTRIA.Salzburg: Leopoldskroner-Moor,490m, June 1877 (fl?), Eysn s.n. (JE). Steiermark: bei Kelsdorf (Graz), 2 August 1910 (fl \& fr), Fröhlich GZU16323(GZU). Kärnten: Carinthia, fluv. Gail, July 1864?(fl), Pichler s.n. (JE, K). Tirol (E.): prope Lienz, July 1863 (fl \& fr), Ausserdorfer s.n. (BM, K).

SWITZERLAND. Zürich: Albis, 3 August 1854 (fl), Hort s.n. (BM). Vaud: Des Pierrettes, près Lausanne, 7 September 1877, Ferrat s.n. (JE). Genève: Compesières, August 1855 (fl), Chavin \& Perrier 55 (BM). Ticino: [Monte] Generoso, Bela Vista, 10 August 1899, Gyoperzer s.n. (JE).

ITALY. Piemonte: Liguria, Portofino Peninsula, 10 September 1963 (fr), Robson 1813 (BM). Lombardia: Brescia, Lago d'Iseo between Vello and Toline, 195 m, 2 June 1983 (fl), Hind 165 (BM, RNG*). Venezia: Verona, Torri del Benaco, 100-200 m, 15 July 1904 (fl), Rigo in Fl. Ital. Exsicc. 817 (BM). Campania: Ravello, above Sta Cattarina, 2 October 1879 (st), Lacaita s.n. (BM). Puglia: Brindisi, 8 km W. of town, 31 May 1960 (fl), Brummitt 60 . E. 802 (K, LIV*). Calabria: Aspromonte, c. $50 \mathrm{~km}$ SW of Reggio di Calabria, below Bova, c. 750 m, 10 June 1979 (fl), Davis \& Sutton D. 64779 (BM).

SICILY. Palermo: c. 5 km W. of Cefalú, 30 m, 25 May 1979 (fl), Davis \& Sutton D. 63726 (BM). Monreale: Weg nach San Martino, 27 May 1927 (fl), Ronniger s.n. (W). Messina: Taormina, 28 May 1964 (fl), Brummitt 4567 (K). Pantellaria: P. Spadillo, 27 May 1960 (fl), Davies s.n. (K).

MALTA. Malta: Kordin (Haslam, Sell \& Wolseley, 1977); occurrence doubtful or plant extinct (Lanfranco, 1982).

SARDINIA. Sassari: near Stintino, La Salina, 5 June 1971 (fl), Dunford \& Moyes $143(\mathrm{BM})$ 
CORSICA. Haute-Corse: Bastia, oberhalb der Stadt, 1 June 1914 (fl), Ronniger s.n. (W); Cirque de Bonifato, près de la Maison forestière, c. $530 \mathrm{~m}$, 8 July 1999 (fl), Lambinon 99/Co.276 (BM, LG*). Corse-du-Sud: Zouya to Porto Vecchio, 21 April 1933 (fl), A.C. \& E. Godman 127 (BM).

FRANCE. Vendée: Mortagne, 24 June 1869 (fl), Genevier s.n. (BM). Deux Sèvres: Puy St. Bonnet, 26 June 1861 (fl), Genevier s.n. (BM). Charante-mar:: Autran, July 1884, Giraudias s.n. (JE). Cher: Allogny, 12 July 1878 (fl \& fr), A.Z.P. s.n. (BM). Saône-et-Loire: Rougers, 4 August 1891 (fl \& fr), Gillot s.n. (BM). Hte-Saône: Goren, près Conflans, 14 September 1858 (fr), Perrier s.n. (BM). Rhône: Arnas, August 1897 (fr), Gandoger s.n. (H). Isère: Viray, vallée du Vézy, August 1910 (fl \& e. fr), Giraudias s.n. (BM). Puy-de-Dôme: Volvic, 750 m, 18 September 1893 (fr), Héribaud in Soc. Rochel. 3438 (BM). Cantal: Anglards de Salers, July 1928 (fl), Chanar s.n. (BM). Hte Savoie: Passy, coteaux au Reyard, 11 July 18 (fl), Depierre s.n. (BM). Savoie: Vérel-Pragondran, près de Chambéry, 19 August 1852 (fl), Chabert in Billot 1847 (BM, JE). Htes-Alpes: environs de Gap, July 1854 (fl), Blanc in Billot 1846 (BM). Alpes-mar.: Cipières village, 700 m, 29 June 1992 (fl), Hepper 9431 (BM, K*). Drôme: Donzère, barrage between Canal and R. Rhône, 17 June 1969 (fl), Verdcourt 2682 (K). Var: $c$. $2 \mathrm{~km}$ NW of Cotignac, 350 m, 5 August 1981 (fl), Longton 4443 (BM). Vaucluse: Entrechaux à Faucon, 23 June 1981 (fl), Bamps 6960 (BM, BR*). Bouches-du-Rhône: Camargue, Canal de Fumemort, 2 km from Tour du Valat, 10 June 1968 (fl), Kendrick \& Moyes 206 (BM). Gard: Saint-Christolles-Alès (S. d'Alès), c. 170 m, 13 July 2000 (fr), Lambinon 0/F/246 (BM, LG*). Ardèche: St. Jean de Pourcharesse, 600 m, 3 September 1984 (fl \& e. fr), Dechamps 10013 (BM, BR*). Aveyron: Chérondels, 15 July 1905 (fl), Carbonel s.n. (BM). Lot: Causse d'Alvignac, July 1868 (fr), Mah-s.n. (BM). Landes: near Dax, June 1924 (fl), Heard s.n. (BM). Aude: Moussan, 28 May 1903 (fl), Septimin-Donat s.n. (BM). Pyrenées-or.: Lorède, 21 June 1906 (fl), Conill s.n. (FR).

BALEARIC ISLANDS. Mallorca: Alcudia, Mal Pas beach, 9 August 1967 (fr), J. \& M. Cannon 3366 (BM). Menorca: San Luis, E. of Punta Prima, c. 10 m, 14 April 1967 (o. fr), Bowden \& Sims 1180 (BM). Ibiza: San Juan Bautista, between Puerto de San Miguel and San Miguel, c. 30 m, 16 January 1971 (st), Ferguson 2773 (BM).

SPAIN. Gerona: N. of Puerto de la Salva, c. 20 m, 17 June 1959 (fl),
Chamberlain 815 (BM). Barcelona: San Celoni, 20 July 1922 (fl), Secondaire in Sennen, Pls d'Espagne 4864 (BM, RNG). Huesca: Sierra de Guara, between Casa de Fabara and Fabara Gorge, 15 August 1970 (fr), I. \& F. Richardson 21 (RNG). Viscaya: Orduña, emirna del Balneariode la Nueva, 10 July 1947 (fl), Guinea 1555 (RNG). León: near Cistierna, 6 July 1927 (fl), Wilmott s.n. (BM). Madrid: Guadalupe, 14 June 1958 (fl), Guinea s.n. (RNG). Ciudad Real: $3 \mathrm{~km}$ SW of Alhambra, Sierra de Alhambra, $950 \mathrm{~m}, 29$ June 1974 (1. fl), Leadley \& Petty 172 (BM, RNG). Albacete: Almansa, W. end of Sierra de El Mugrón, 1150 m, 22 June 1979 (fl), Reading Univ. Bot. Dept. Exped. 150 (BM, RNG). Valencia: Utiel, Utiel to Pantano de Generalissimo, $21 \mathrm{~km} \mathrm{~N}$. of town, $641 \mathrm{~m}, 20$ June 1979 (bud), Reading Univ. Bot. Dept. Exped. 55 (BM, RNG). Almería: Laujar de Andarax, Nacimiento, c. 900 m, 8 July 1978 (fl), Roivainen s.n. (H*, RNG). Jaen: Sierra de Cazorla, near Cueva de la Magdalena, 900 m, 7 July 1951 (fl), Heywood 1058 (BM, RNG). Cordoba: Sierra Morena, Cjo N. S. of Fuenta Sagra, 7 km W. of Cordoba, 10 June 1927 (fl), Wilmott s.n. (BM). Granada: Puerto de la Ragua, crossroads with road to Alpujana, 1400 m, 19 June 1988 (fl), Valdès et al. 1011 (RNG). Málaga: Marbella, 500 m, N. de Puerto Cabopino, 30 m, 10 August 1984 (fl), Michel 7029 (BM, BR*). Sevilla: entre Cantillana y Alcolea del Río, Km 9.0-9.1, 11 May 1986 (bud), López \& Molina CL 791/ 86 (RNG, SEV*). Huelva: c. $5 \mathrm{~km}$ S. of Aracena on road N433, $600 \mathrm{~m}, 3$ July 1974 (fl \& fr), Leadley \& Petty 205 (BM, RNG).

GIBRALTAR. Guadacarte, 23 May 1927 (fl \& fr), Croffen s.n. (BM).

PORTUGAL. Minho: Caldas do Gerês, June 1887 (fl), Murray s.n. (BM), Trás-os-Montes: 6.4 km N. of Bragança, 450 m, 9 August 1957 (fl), Epsom College 325 (BM). Beira littoral: Coimbra, prope Carreira do Tiro, $50 \mathrm{~m}, 8$ June 1936 (fl), Rothmaler s.n. (JE). Estremadura: Torres Vedras, arredores de Runa, July 1881 (fr), Barros \& Cunha s.n. (BM). Ribatejo: Serra Monte Junto, $2 \mathrm{~km}$ from Cercal, above São Salvador, 300 m, 6 July 1974 (fl), Leadley \& Petty 259 (BM, RNG). Baixo Alentejo: Sines, proximo do Monte de Chaminé, 13 June 1981 (fl), Barbosa, Gomes \& Morena 13889 (RNG).

AZORES. Graciosa: Monte d'Ajuda, 30 m, 7 July 1971 (fl), Gonçalves 3003 (BM).

MADEIRA. Monte, 550 m, 19 October 1984 (fl \& fr), Short 13 (BM). Ponta do Clerigo, 480 m, 11 June 1985 (fl), Press 896 (BM).

CANARY ISLANDS. Santa Cruz: Calderata, 1 June 1913 (fl), Sprague

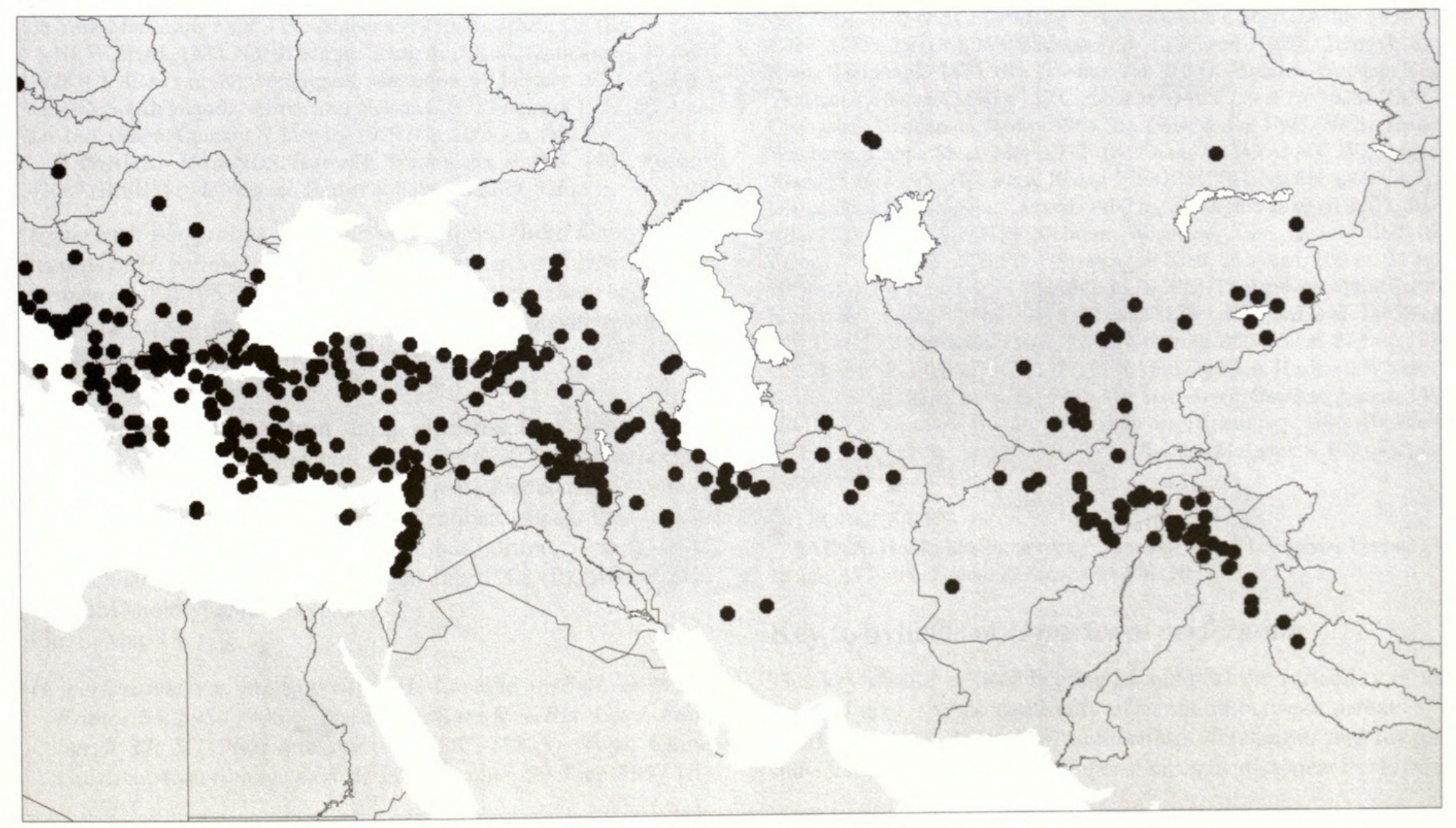

Map 11 5c. H. perforatum subsp. veronense, Orient and Central Asia 
\& Hutchinson 189 (K). Tenerife: Teneriffe, 1845 (fr), Bourgeau 246 (BM).

Las Palmas: near S. Cruz, June 1892 (fl), Murray s.n. (BM).

MOROCCO. Tanger: Tangier, July, Schousboe s.n. (JE). Rif: Targuist, Targuist to Al Hoceima, 3 km W. of Beni-Hadifa, 960 m, 29 June 1993 (fl), Jury 11278 (BM, RNG). Centre nord: Zerhouan, ruins of Roman city of Volubilis, 390 m, 4 June 1994 (fl), Jury 14865 (BM, RNG). Moyen Atlas: Taza, c. $42 \mathrm{~km}$ from Taza to Sidi Abdallah, around Jbel Tazzeka, $1200 \mathrm{~m}, 15$ June 1992 (fl), Optima Iter V 996 (RNG). Haut Atlas: Demnat, Djebel Tihlatin, tribu de Ait Maala [Mahala], 25 July 1879 (fr), Ibrahim s.n. (BM).

ALGERIA. Oran: Tlemcen, 15 June 1917 (fl), Faure s.n. (BM). Alger: Gorge de Chiffa (Blida-Medea), 500 m, 11 June 1971 (fl), Davis 53451 (BM). Kabylie: between Tizi Ouzou and Makouda, Oued Sebaou, 50-100 m, 17 June 1975 (fl), Davis 59146 (BM).

TUNISIA. NW mountains (regions Kroumirie, Mogods, Dorsale Tunisienne), fide Pottier-Alapetite (1979: 508).

SUDAN REPUBLIC. Darfur: Jebel Marra, Wadi Saria, $2300 \mathrm{~m}, 8$ March 1983 (fr), S. Miehe 958 (BM); Jebel Marra, S. of Jebel Abau, c. 2600 m, 7 December 1954 (l. fl), Jackson 3335 (K).

SAUDI ARABIA. Asir: Taif-Al Baha-Jabal Ibrahim road, $15 \mathrm{~km} \mathrm{~N}$. of Al Mindak, 2040 m, 17 March 1987 (fl \& e. fr), Collenette 6079 (BM, E*, K).

ISRAEL. Upper Galilee: near Dafneh [Dafna?], 27 May 1945 (fl), Norris s.n. (BM).

LEBANON. Coast: environs de Brumana, July to September 1979?, Cramer s.n. (G); Baynu, 13 June 1943 (fl), Davis 6412 (BM, K). Lebanon: Cedars, 20 July 1865 (fl), G. Post s.n. (K); Zahleh [Zahlé], 7 May 1875 (fl), Post 809 (K).

SYRIA. North: Monts Nusairy, Ain Halakim, 750-900 m, June 1910 (fl), Haradjian 3537 (K); $20 \mathrm{~km} \mathrm{~S}$. of Urdu [Ordu], 800-900 m, 8 June 1938 (fl), Dinsmore 20360 (K).

CYPRUS. Kyrenia: environs du Monastère Armenien, 600-900 m, 2630 May 1912 (fl), Haradjian 348 (K). Paphos: Lisso [Lyso], c. 600 m, 10-16 June 1913 (fl), Haradjian 851 (K). Troödos: distr. Limassol, between Vasa and Agios Amvrosios, 21 May 1941 (fl), Davis 3538 (BM, K).

IRAQ. Amadiyah: Rowandiz [Rowanduz] Gorge, 24 June 1934 (e. fr), Field \& Lazar 856 (BASBG, K, W); 35 km NE of Zakho, Daimka village, 820 m, 5 July 1976 (fl), Al-Kaisi \& Hamid 45365 (K). Rowanduz: Bekarl,
2200 m, 2 August 1956 (fl), Haley 17 (BM); Erbil distr., Montes Qandil, Pushtashan, c. 1100 m, 28 July-1 August 1957 (fl), K.H. Rechinger 11035 (W). Sulimaniyah: Sulimanieh, in mont., June 1867 (fl), Haussknecht s.n. (BM, K); Sulaimaniya liwa, A’hmidau swamp, 28 July 1964 (fl), Makki 551 (W).

IRAN. Azarbaijan: Tabriz to Marand, 1500 m, 27 July 1971 (1. fl), Termé EVIN 34352E (BM, EVIN*). Kordestan: $64 \mathrm{~km} \mathrm{SW}$ of Mahabad, $1500 \mathrm{~m}$, 29 July 1962 (fl), Furse 3494 (K, W). Lorestan: Bicheh, 1100 m, 29 May 1937 (fl), Köie 1506 (C*, W). Kohkiluyeh va Buyer Ahmadi: Tale' Khosravi to Sissakht, 29 July 1949 (fl), Beh houdi 975E (W). Zanjan: pass between Zandjan and Rudbar, 36 km from Zandjan, 2100 m, 9 July 1972 (fl), Goldblatt 776 (BM). Hamadan: Hamadan, 2100 m, 7 September 1929 (fl), Rogers 9507 (BM, K). Gilan: Astara to Resht, 16 km S. of Astara, 30 m (by Caspian shore), 7 June 1962 (fl), Furse 2846 (K, W). Mazandaran: Elburz Mts, above Allamul, between Chalus and Karadz, c. 1980 m, 23 June 1966 (fl), Archibald 2403 (E, K). Tehran: prope urbem Teheran, 1843 (fl), Kotschy 756 (BM, K); Haft Hartz Valley, N. of Teheran, 2100 m, June 1934 (fl), Trott 181 (K). Khorasan: in montibus inter Budjnurd [Bujnurd] et Morawe Tappeh, c. 1300 m, 25-27 July 1937 (fl \& fr), K.H. \& F. Rechinger 1875 (W).

AFGHANISTAN. Farah?: Khash-Dt., 2400 m, 8 August 1937 (fr), Koelz 12913 (W). Fariab: c. $6.5 \mathrm{~km} \mathrm{~N}$. of Darrah Zang village, $c .1320 \mathrm{~m}$, 30 June 1971 (fl), Grey-Wilson \& Hewer 1312 (K). Jozjan: Tuzkar, 1200 m, 15 September 1939 (fr), Koelz 13977 (W). Baghlan: Salang Pass, N. side, 1800 m, 24 June 1966 (fl), Furse 8056 (K). Parwan: montée sud vers Col de Salang, 2500 m, August 1964 (fr), Haysu 487 (W). Kabul: Paghman, 25.6 km W. of Kabul, 2400-2700 m, 23 June 1939 (fl), Chaworth-Musters s.n. (BM). Logar: Ghorband, 1700 m, 14 August 1938 (fr), Köie 2789 (W). Konar: 17.6 km NW of Kamdesh towards Barg-i-Matal, c. 1567 m, 3 July 1969 (fl), Hewer 1378 (K). Nangarhar: Mama Kheyl, 1200 m, 23 May 1937 (fl), Koelz $11576(\mathrm{~W})$.

PAKISTAN. Kurram: Kurram Valley, Ziran, Imam Bagh, 30 August 1972 (fr), Kazmi 3749 (H). Dir: Lowari, 6 July 1968 (fl), Nasir 5108 (RAW). Swat: Khawazakiela to Shangla, c. 1300 m, 2 June 1965 (fl), Lamond 1691 (E, KUH). Hazara: Jabri, 10 km from Shogran, 15 April 1978 (fl), Muq. Shah \& Dil. Khan 2403 (BM, ISL*). Chitral: Kesu, 1290 m, 24 May 1958 (e. fr), Bowes Lyon 714 (BM, RAW, W). Gilgit: Buni, 2100 m, 1876? (fr), Giles 392 
(K). Baltistan: Balti, 2400 m, June 1915, Schlich 56 (BM).

INDIA. Kashmir: Manasbal, 1560 m, 5 June 1940 (fl), Ludlow \& Sherriff 8120 (BM). Himachal Pradesh: Pangi, Chenab R., N. bank between Darwas and Ishtwari, c. 2400 m, 12 June 1981 (fl), Sayers 3713 (BM). Uttar Pradesh: Tihri-Garhwal, Ganges valley near Jángla, 2400-2700 m, 12 July 1883 (st), Duthie 977 (BM).

TURKMENISTAN. Aschabad: ad montem Aktepe [Kopet-Dag], 17 June 1900 (fl), Sintenis 564a (BM, K); Kisil Arwat, Karakala, m. Sundsodagh, 31 May 1901 (fl), Sintenis 1862 (JE).

UZBEKISTAN. Taschkent, bei Tschimgan, westlich Ausläufer des Tian Shan, 1700 m, 14 July 1975 (fl), Breckle 3632 (K); Denauskiy raion, Akhunbabeva, 1 July 1938 (fl), Parabskaya s.n. (LE).

TAJIKISTAN. Pamiro-Alai, Zalekhsi, N. slope of Aatni, R. Gulibysta 4 $5 \mathrm{~km} \mathrm{~N}$. of Stalinabada [Dushanbe], 7 June 1942 (fl), Grigoriev 225 (LE); Kondor Gorge, $30 \mathrm{~km} \mathrm{~N}$. of Dushanbe, W. side of R. Varzob, 1100 m, 13 July 1975 (fl \& e. fr), Pankhurst \& James 93 (BM).

KYRGYZSTAN. Tian-schan occid., in valle fl. Talos, prope pagum Pokrovka, 14 June 1919 (fl \& fr), Kushelev in HTU 077243 (TAI); Ferganskiy khrebet, Arslanbobskiy nut farm, R. Yasky-chu, 11 October 1933 (fr), Sokolov s.n. (LE).

KAZAKHSTAN. Semirychensk prov., Vyernyy [Almaty] distr., Zayliyskiy (Trans-Ilian) Alatau, 14 July 1907 (fl), Sokalsky 118 (BM); Ketmenskiy khrebet, Ushchelye, R. Ketmen, 20 September 1931 (fr), Rodin 1508 (LE).

\section{INTRODUCTIONS}

SOUTH AFRICA. Cape Province: Stellenbosch, College of Agriculture, 23 November 1948 (fl), Hulme s.n. (BM, K); Cape Town, slopes of Papegaaiberg, c. 105 m, 15 January 1969 (l. fl), Taylor 7376 (K, PRE*).

RÉUNION. See Robson \& Stevens, Flore des Mascareignes 49. Guttifères: 6 (1980). These populations probably belong to subsp. veronense, but the specimens have not been re-studied.

AUSTRALIA. New South Wales: Faulconbridge, 435 m, 17 November 1982 (fl), Coveny 11405 (K, NSW*). A.C.T.: Canberra, Jarrabomberra Avenue, just S. of junction with Narrabundah Lane, 580 m, 5 December 1980 (fl), Canning 5031 (BM, CBG*). Victoria: Far NE, Corryong, near Anzac Drive, 25 November 1972 (fl), R.V. Smith 72/57 (K, MEL*). South Australia: Mt Lofty Ranges, Blackwood, 251 m, [comm. April 1929] (l. fl), Pritchard s.n. (BM, K, GH). Western Australia: approx. 8 km NE of York on York-Meckering road, 7 November 1979 (bud), Dixon s.n. (K).

NEW ZEALAND. North Island: South Auckland, Taumarunui, 20 April 1928 (fl), Allan s.n. (K); Wellington, Masterton, 10 January 1929 (fl), Allan s.n. (K). South Island: Nelson, near Nelson City, 23 January 1929 (fr), Allan s.n. (K); Otago, Oamaru, 9 January 1929 (fl), Allan s.n. (K).

HAWAIIAN ISLANDS. Hawai'i: North Kona, Huallai, 1961, Fosberg 42087 (BISH*) (fide Wagner, Herbst \& Sohmer, 1999: 526).

Hypericum perforatum var. collinum Woron. (from Georgia) and records of $H$. veronense and $H$. perforatum var. veronense from the Crimea (Vul'f, 1953: 110) and the Caucasus region both apparently refer to a narrow-leaved form of subsp. veronense with interrupted rather than vesicular lateral capsule vittae.

5d. Hypericum perforatum subsp. chinense N. Robson, subsp. nov. ${ }^{5}$ A subsp. perforatum inflorescentiis vel inflorescentiis partialibus vel inflorescentiis totis et partialbus congestis, ramulis pro ratione longis curvato-ascendentibus, petalis glandulis in lamina insertis nigris vel carentibus, differt. Type: China, Sichuan, Wa-shan, 2100-2400 m, July 1908 (fl), Wilson 2425 (BM!-holotype; A-isotype).

Fig. 8, Map 13.

H. perforatum var. microphyllum H. Léveillé in Bull. Soc. Bot. France 54: 595 (1908); Lauener in Notes Roy. Bot. Gard. Edinburgh 27: 5 (1966) qua syn.; non DC. (1815). Type: China, Guizhou, Kouy-yang, pied de la montagne, 28 June 1897 (fl),
Bodinier 1665 (E-holotype; BM!-isotype)

H. foliosissimum Koidz. in Acta Phytotax. Geobot. 3: 215 (1934); Nemoto, Fl. Japan, Suppl.: 483 (1936). Type: Japan, Honshu, Prov. Sima, Kamomura, Arasima, 27 July 1934, T. Ito s.n. (? holotype). See note on next entry.

H. perforatum var. angustifolium sensu Ohwi, Fl. Japan: 781 (1936); Y. Kimura in Bot. Mag. (Tokyo) 52: 406, f. 9 (1938), in Nakai \& Honda, Nova fl. jap. 10: 133, ff. 47, 48 (1951); Momiyama in Satake et al., Wild Fls Japan 2: 118, t. 114 f. 3 (1982). Momiyama states that the Japanese plant was originally introduced from Europe; but examination of Japanese specimens indicates that they match subsp. chinense rather than the south European subsp. veronense.

Icon: Li Xiwen in Fl. R. P. Sin. 50(2): 68, t. 15, ff. 1-4 (1990).

Leaves petiolate; lamina (7-)10-25 × 3-7(-15) $\mathrm{mm}, \pm$ narrowly elliptic to narrowly oblong or linear $(1: b=2.5-3.5)$, base rather narrowly cuneate to subcordate-amplexicaul, ?glaucous beneath. Inflorescence and/or partial inflorescences congested, branches relatively long, curved-ascending. Petals with laminar glands black, linear to punctiform, or often absent. Capsule valves with lateral vittae linear, narrow or somewhat interrupted or shortened but not swollen.

China (eastern Qinghai and Gansu east to Shandong and south to Yunnan and Guizhou). The northern populations tend to have larger and relatively broader leaves.

CHINA. Hebei: fide Li Xiwen (1990). Shanxi: fide Li Xiwen (1990). Shaanxi: Zhouzhi Xian, Chenhe Xiang, 1400 m, 14 August 1958 (fl \& fr), Zhang 44 (IBSC, KUN, NAS); Chungmanshan, Hsingpaochuan, 20 August 1934 (fl \& fr), Pai 1071 (PE); Tai-pei Shan, 1910 (fr), Purdom s.n. (K). Gansu: Yanchang Xian, Gongjiagou, 2150 m, 1 July 1989 (fl \& fr), Yuan 1008 (A, BM, CAS, PE*); Tianshui, 1350 m, 20 July 1951 (fl \& fr), Zhang 46 (KUN, PE). Henan: Lushi Xian, 1660 m, 2 October 1958 (fr), $F u 1640$ (IBSC); Xichuan Xian, Lugou Sandaohe, 220 m, October 1956 (fr), Henan For. Dept. 1445 (PE). Shandong: Fei Hsien, Mong Shan, 12 July 1936 (fl), Cheo \& Yen 38 (BM, W). Jiangsu: fide Li Xiwen (1990). Jiangxi: Kew Kiang [Jiujiang], 1873 (fl), Shearer s.n. (BM). Hunan: Wugang Xian, Yunshan, Qishucao, 1150 m, 17 October 1963 (fr), Liu \& He 16288 (IBSC); Changsha, Xiaonamen, 9 May 1964 (fl), Chen \& Yue 1498 (NAS). Hubei: Wuchang, Luojia Shan, May 1932 (fl), Chung 9034 (A, NY, W); Badong Xian, 15 July 1957 (fl), Fu \& Zhang 776 (IBSC, KUN); Shennongjia For. Distr., along Qiadonggou Canyon, 1900 m, 27 August 1980 (fl \& fr), SinoAmer: Exped. 396 (A, NY). Sichuan: Wenchuan Xian, 23 July 1928 (fl), Fang 1492 (GH, K, NY, PE, US); Fengjie Xian, Zhuyuan, 600 m, 24 July 1958 (fl \& fr), Chang 25617 (IBSC, KUN, PE); Dujiandyan Municipality, Longxi For. Farm, 800 m, 2 September 1988 (fr), Boufford et al. 14433 (A, BM, CAS, NY, PE*). Guizhou: Pin-fa, Kweiting, 400-550 m, 27 June 1930 (fl), Tsiang 5341 (IBSC, NAS, NY, PE); Yinjiang Xian, Huguosi, W. side of Fanjing Shan, 22 September 1986 (fl), Sino-Amer. Guizhou Exped. 1453 (BM, NY). Yunnan: vicinity of Yunnan-sen [Kunming], 1906 (fl), Maire 1505 (K); no precise locality, July 1936 (fl \& fr), McLaren U.109 (A); [also Cavalérie $3125(\mathrm{~K})]$.

\section{INTRODUCTIONS}

JAPAN. Hokkaidō: Furano city, Yamabe, Tokyo University Forest, 1315 July 1979 (fl), Sohma \& Takahashi 478 (H).

\section{Key to hybrids of Hypericum perforatum}

This key should be used bearing in mind (a) the variability of the parental taxa, (b) the continuity of variation between parents and hybrids of $H . \times$ desetangsii nothosubsp. desetangsii and (c) that subsidiary lines present in younger stems may disappear in old ones 


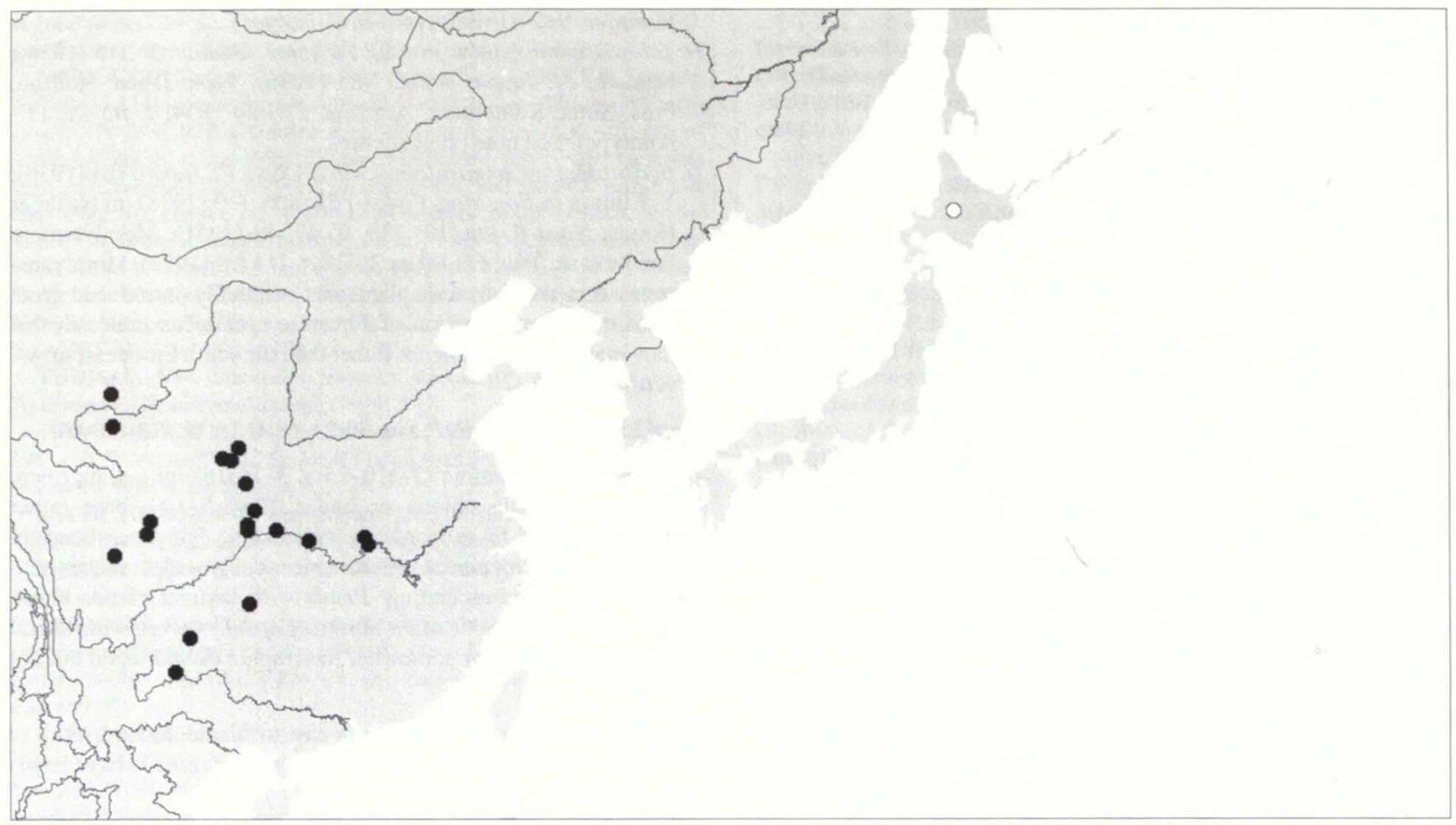

Map 13 5d. H. perforatum subsp. chinense $\bullet$, introduced $\bigcirc$.

1 Stem internodes 2-lined (from leaf bases) or with weaker and usually incomplete subsidiary lines (from between leaves); leaves relatively laxly reticulate-veined ... 2

Stem internodes \pm completely 4 -lined; leaves relatively densely reticulate-veined.....

5

2(1) Stem internodes 2-lined only; sepals usually narrow, more rarely broad, always acute with a hair point; capsule valves with not very numerous vittae to punctiform vesicles . ... 3

Stem internodes also with weakly developed subsidiary lines; sepals narrow or quite broad, acute; capsule valves with relatively numerous narrow longitudinal vittae

4

3(2) Sepals entire, lanceolate; capsule with lateral vittae linear and shortened; leaves spreading, venation sometimes densely reticulate $5 \mathrm{xx} . \times$ medium

Sepals eroded-denticulate to glandular-ciliate, elliptic to lanceolate; capsule with lateral vittae linear or absent, not shortened; leaves often deflexed, venation laxly reticulate

... 5 xbb. $\times$ desetangsii nsubsp. carinthiacum nf. perforatiforme

4(2) Sepals narrowly oblong to linear-lanceolate, finely acuminate or apiculate, eroded-denticulate to entire; leaves usually rather densely pale-gland-dotted ............ 5xa. $\times$ desetangsii nsubsp. desetangsii

Sepals broadly elliptic to linear-lanceolate, acute to acuminate, \pm eroded-denticulate to subfimbriate or entire; leaves sparsely palegland-dotted

... 5xbb. $\times$ desetangsii nsubsp. carinthiacum nf. perforatiforme

5(1) Leaves usually rather densely pale-gland-dotted, venation very laxly to rather densely translucent-reticulate; sepal apex usually very acute or eroded-denticulate with fine hair-point; sepals and petals with sparse dark glands

5xa. $\times$ desetangsii nsubsp. desetangsii

Leaves without or almost without pale gland dots, venation rather densely translucent-reticulate; sepal apex obtuse or subacute, entire or finely denticulate, without distinct hair-point; sepals and petals without or with relatively numerous dark glands

... 6

6(5) Petal laminar glands all or some black; leaf apex obtuse, not acute, base cuneate to rounded

... 5xba. $\times$ desetangsii nsubsp. carinthiacum nf. maculatiforme

Petal laminar glands all pale; leaf apex obtuse or sometimes sometimes acute, base cuneate to cordate-amplexicaul . $5 x c . \times$ desetangsii nsubsp. balcanicum

5x. Hypericum $\times$ desetangsii Lamotte in Bull. Soc. Bot. France 21: 121 (1874); Bonnet in Bull. Soc. Bot. France 25: 277 (1878); Schinz in Bull. Herb. Boissier II, 3: 11, 13 (1902), in Vierteljahrsschr Naturf. Ges. Zürich 49: 241 (1905); Tourlet in Bull. Soc. Bot. France 50: 307 (1903); Thellung in Allg. Bot. Z. 1912: 19 (1912); Salmon in J. Bot. (Lond.) 51: 317, t. 528 (1913); R. Keller in Engl. \& Prantl, Nat. Pflanzenfam., 2nd ed. 21: 179 (1925); N. Robson in Bot. Soc. Brit. Isles Proc. 3: 99 (1958), in Bull. Br. Mus. (Nat. Hist.), Bot. 8: 168, f. 55 (1981), in Wisskirchen \& Haeupler, Standardliste Farn- u. Blütenpfl. Deutschl.: 268 (1998); A. Fröhl. in Preslia 32: 97-99, f. 2 (1960); O. Schwarz in Drudea 5: 64 (1965). Type: France, Aube, Chapelle-St.-Luc près Troyes, 11 July 1841 (l. fl), Des Étangs s.n. (CLF!-lectotype, selected here); Garenne de Villechétif près Troyes, 5 August 1840 (e. fr), Des Étangs s.n. (K!-syntype). But see note under 1x. H. × laschii (p. 76) regarding the identity of these Des Étangs specimens.

Fig. 9, Maps 14, 15.

H. maculatum Crantz $\times$ H. perforatum L.; A. Fröhl. in Sitzungsber. Kaiserl. Akad. Wiss., Math.-Naturwiss. Kl. 120(1): 557 (1911).

Stems almost completely 4 -lined to 2 -lined. Leaves broadly ovate or 

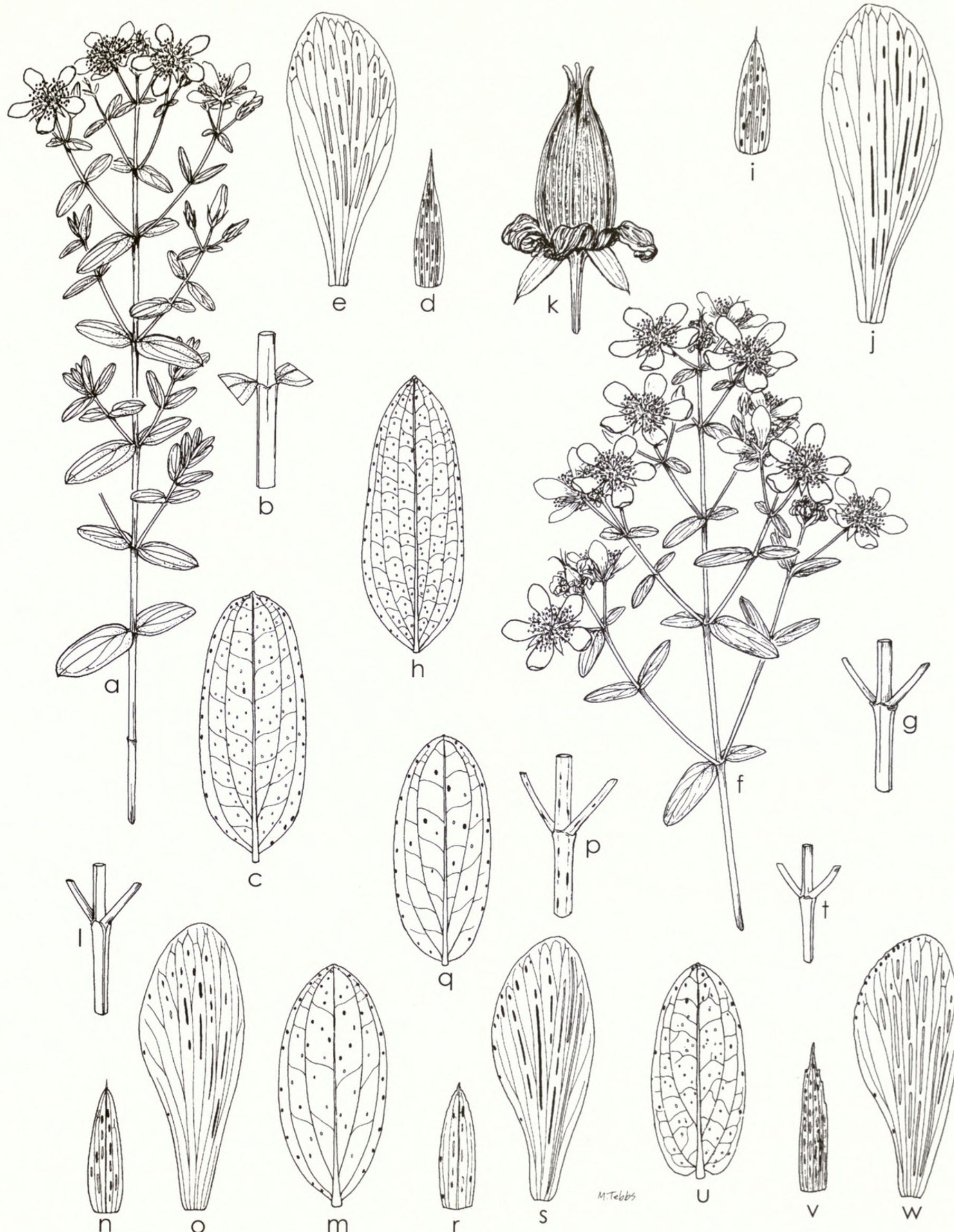

Fig. $9 H . \times$ desetangsii: A. nsubsp. desetangsii: (1): (a) branch; (b) stem section; (c) leaf; (d) sepal; (e) petal. B. nsubsp. desetangsii: (2): (f) branch; (g) stem section; (h) leaf; (i) sepal; (j) petal; (k) capsule. C. nsubsp. carinthiacum nforma perforatiforme: (l) stem section; (m) leaf; (n) sepal; (o) petal. D. nsubsp. carinthiacum nforma maculatiforme: (p) stem section; (q) leaf; (r) sepal; (s) petal. E. nsubsp. balcanicum: (t) stem section; (u) leaf; (v) sepal; (w) petal (a, f $\times 2 / 3$; b, c, g, h, l, m, p, q, t, u × 2; rest × 4). A. Anon. s.n. (France, Puy de Dôme). B. Salmon s.n. (England, Sussex). C. Kerner 3649. D. Lillefosse s.n. E. Rechinger 782. 
broadly elliptic or ovate-oblong to linear; tertiary reticulate venation dense to lax; pale laminar glands dense (especially in upper leaves) to very few. Sepals broadly elliptic to linear-lanceolate, obtuse to acuminate, entire or \pm eroded-denticulate to subfimbriate. Petals with black laminar glands rather numerous to few, mostly linear to mostly punctiform, or absent; black marginal glands present. Capsule with vittae all linear and vertical or some lateral, oblique and irregular to elongate-vesicular.

Intermediate between the parents, but back-crossing to both at the tetraploid level of $H$. maculatum (subsp. obtusiusculum) has resulted in a complete series of intermediate forms of $H$. $\times$ desetangsii nothosubsp. desetangsii (cf. Crackles, 1990). At the diploid level (subsp. maculatum), two distinct forms of nothosubsp. carinthiacum occur, one triploid $(2 n=24)(H$. maculatum $\quad(n=8) \times H$. perforatum

$(\mathrm{n}=16)$ or, probably rarely but conceivably, H. perforatum $\quad(\mathrm{n}=16$, i.e. reduced $\times H$. maculatum $(n=8))$, the other pentaploid $(2 n=40)$ (H. perforatum $(\mathrm{n}=32$, i.e. unreduced $) \times H$. maculatum $(\mathrm{n}=8))$. In the cross with subsp. maculatum (nothosubsp. carinthiacum), these forms are at least sometimes distinguishable (respectively nothoforma maculatiforme and nothoforma perforatiforme); but in the cross with the presumed diploid subsp. immaculatum (nothosubsp. balcanicum), no distinct morphological forms are apparent and no chromosome counts have yet been made. As the specimens with this alleged parentage are intermediate between the parents, however, they are likely to be triploid. See Noack (1939) for a discussion of the cytology, but not the nomenclature.

Although records are scattered, distribution of the hybrids would appear to be confined to the areas of distribution overlap of the parents; but vegetative propagation and (in nothosubsp. desetangsii) partial fertility of the hybrids have sometimes resulted in their occurrence in the absence of one or both parents.

5xa. Hypericum $\times$ desetangsii Lamotte nothosubsp. desetangsii N. Robson in Wisskirchen \& Haeupler, Standardliste Farn- $u$. Blütenpfl. Deutschl.: 268 (1998).

Map 14.

5. H. perforatum L. $\times$ 1c. H. maculatum subsp. obtusiusculum (Tourlet) Hayek

H. perforato-quadrangulum Lasch in Linnaea 4: 415 (1829).

H. linnaeanum Callay \& Gren. in Gren., Fl. jurass. 1: 154 (1863), nomen.

?H. $\times$ mixtum Du Moulin in Oesterr. bot. Z. 17: 390 (1867); A. Fröhl. in Sitzungsber. Kaiserl. Akad. Wiss., Math.-Naturwiss. Kl. I, 120(1): 568 (1911), in Mitt. Naturwiss. Vereins Steiermark 51: 227 (1915). Type: Germany, Bavaria, bei Neuburg, Bertolzheim, Du Moulin s.n. (W?- holotype). It is not certain from the description whether this is an earlier synonym of $H . \times$ desetangsii or a later synonym of $H$. maculatum Crantz (cf. Mártonfi, Repcák \& Mihoková, 1996b). Fröhlich (1911: 568) was unable to find the type specimen in W; so, unless or until it is discovered and proves to be $H$. $\times$ desetangsii, it seems best to maintain the well known name.

H. desetangsii var. genuinum Bonnet in Bull. Soc. Bot. France 25: 277 (1878); Burnat, Fl. Alpes marit. 2: 27 (1896); Schinz in Bull. Herb. Boissier II, 1: 14, 21 (1902), in Vierteljahrsschr. Naturf. Ges. Zürich 49: 241 (1905). Type as for H. $\times$ desetangsii Lamotte.

H. acutum subsp. desetangsii (Lamotte) Rouy in Rouy \& Fouc., Fl. France 3: 336 (1896), comb. illegit. (Art. 52).

H. acutum subsp. desetangsii var. genuinum (Bonnet) Rouy in Rouy \& Fouc., Fl. France 3: 336 (1896), comb. illegit. (Art. 52).

H. quadrangulum subsp. desetangsii (Lamotte) Tourlet in Bull. Soc. Bot. France 50: 307 (1903); A. Fröhl. in Oesterr. Bot. Z. 63: 18
(1913), in Mitt. Naturwiss. Vereines Steiermark. 51: 220 (1915); Hegi, Ill. Fl. Mitt.-Eur. 5(1): 518 (1925).

H. maculatum subsp. erosum (Schinz) A. Fröhl. $\times$ H. perforatum L. sensu A. Fröhl. in Sitzungsber. Kaiserl. Akad. Wiss., Math.Naturwiss. Kl. 120(1): 559 (1911).

H. maculatum subsp. obtusiusculum (Tourlet) Hayek $\times$ H. perforatum L., A. Fröhl. in Oesterr. Bot. Z. 63: 15 (1913).

H. $\times$ desetangsii nothovar. desetangsii qua nothomorph sensu N. Robson in Tutin et al., Fl. Europaea 2: 269 (1968), in Cullen et al., Eur. gard. fl. 4: 60 (1995).

H. erosum (Schinz) O. Schwarz in Drudea 5: 63 (1965) pro parte quoad typum. Type as for H. quadrangulum var. erosum Schinz.

Icon: Salmon in J. Bot. (Lond.) 51: t. 528 (1913).

Stems usually partially 4-lined. Leaves ovate or broadly elliptic to narrowly oblong or linear; tertiary reticulate venation dense to lax; pale laminar glands usually present, sometimes dense, especially in upper leaves. Sepals narrowly oblong to lanceolate or linear-lanceolate, eroded-apiculate to acuminate and entire or denticulate. Petals with black laminar glands usually few, linear to elongate-punctiform, and some marginal. Capsule with vittae all linear and vertical or some lateral, oblique and linear to elongate-vesicular. $2 n=32,40$ \& 48 (Robson, 1956, 1975, 1981; Robson \& Adams, 1968; Mártonfi et al., $1996 a$ ). For record of $2 n=24$, see p. 105.

Habitat range of the parents excluding extremes of humidity.

Distribution of H. maculatum subsp. obtusiusculum, i.e. NW Europe south to central France and Switzerland and east to western Germany and Austria.

SCOTLAND. S. Aberdeen: Drum, bank of R. Dee, 15 August 1956 (fr), Robson s.n. (BM). W. Perth: Perth, R. Tay, Moncrieffe I., 17 July 1938 (fl), Mackechnie \& Wallace s.n. (BM, K). Argyll: Dunoon, 23 July 1888 (fl), King s.n. (BM). Ayr: West Kilbride, 24 July 1973 (fl), B. Simpson s.n. (BM). Renfrew: Mr Hutcheson's School playing fields, 12 September 1987, Dickson s.n. (GL). Lanark: Rotten Calder at Redlees Quarry, 13 September 1987 (fl), Dickson s.n. (GL). Berwick: Earlston, 1926 (e. fr), Hayward s.n. (BM).

ENGLAND. Cumberland: between Little Skelton and Ellaby, 19 June 1969 (fl), Halliday s.n. (LANC). Durham: near Nunstanton Carr, 82 m, 18 July 1975 (fl), Graham 8714 (BM). NW Yorks.: Swaledale, Langton, 23 August 1967 (1. fl), Gillingham s.n. (BM). SE Yorks.: Harswell old station, 20 July 1988 (fl), Duncan s.n. (BM). S. Lancs.: Wigan, Gathurst, 1947 (fl), Edmondson LIV1975.560.7 (LIV). Cheshire: Castle Mill, 1 August 1867 (fl), Bailey s.n. (BM). Shropshire: Craig Llwyn, 28 September 1971 (fr), Benoit s.n. (BM). Oxford: Hailey, Synge Wood, 13 September 1946 (l. fl), $N$. Simpson 46302 (BM). Bucks.: between Cadmore End and Fingest, 11 August 1946 (fl), Sandwith 3139 (BM). S. Essex: Woodhatch near Theydon Boys, 19 July 1914 (fl), C.E. Britton 1247 (K). W. Kent: S. of Ightham Court, 8 September 1957 (e. fr), McClintock s.n. (BM). Surrey: Burgh Heath, Perrott's Farm, 15 August 1929 (1. fl), Wallace s.n. (BM). E. Sussex: Lewes, Seaford Road, 11 July 1936 (fl), N. Simpson 36868 (BM). Dorset: near Wimborne, 22 August 1928 (fl), L.B. Hall in N. Simpson 45808 (BM). S. Devon: A 373 between Honiton and Awliscombe, 19 July 1989 (fl), Margetts s.n. (BM).

WALES. Glamorgan: near Lisvane, Cefn On Halt, 3 July 1968 (fl), Pinkard s.n. (H). Radnor: near Builth Beacon, 18 August 1940 (fl), Pugsley s.n. (BM). Merioneth: near Barmouth Junction (Morfa Mawddach) station, 5 October 1971 (fr), Benoit s.n. (BM). Caernarvon: Bangor, Talybont, Penbryn, 27 August 1972 (fl), Roberts (BM). Denbigh: Llangollen, 15 August 1953 (fl), Herb. Liverpool Mus. 1973.305.356 (LIV).

IRELAND. Recorded from West Kerry only (Scannell \& Synnott, 1987), but likely to be more widespread.

FRANCE. Aisne: Villers-Cotterets, 17 August 1879 (1. fl \& e. fr), Bonnet in Soc. Dauph. 2409 (BM, FR). Oise: Aulmont près Senlis, 25 September 1835 (fr), Gay s.n. (K). Seine-et-Marne: Nemours, 17 July 1892 (fl), Jeanpert 631 (BM). Aube: Villechétif [loc. class.], 29 July 1989, Guyot s.n. (H); see p. 102. Côte-d'Or: Magny-la-Ville, June 1887 (fl), Wilmott s.n. (K). 


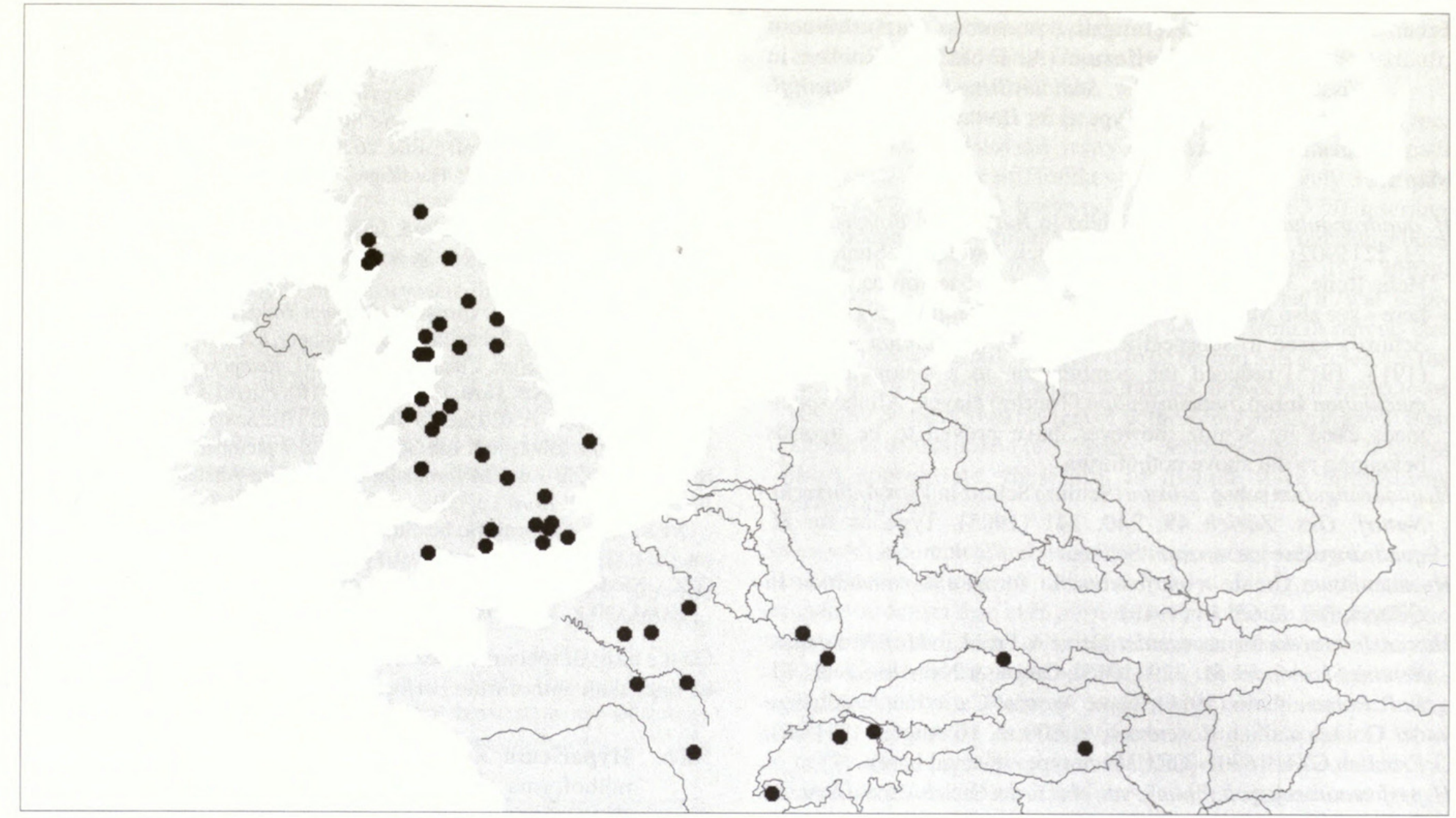

Map 145 xa. H. $\times$ desetangsii nsubsp. desetangsii $\bullet$. Recorded in Ireland only from the south-west (Co. Kerry), but possibly more widespread.

Saône-et-Loire: Curgy, près Autun, 6 August 1889 (fl), Gillot 435 (BM). Allier: Sussat, la Veauce, July 1873 (fl), Déséglise s.n. (BM). Hte-Vienne: le Dorat, 5 July 1929 (fl), Elias in Héribaut-Joseph 441 (BM). Hte-Savoie: Constans, 2 August 1896 (fl), Boreau s.n. (BM). Savoie: Fôret d'Apremont [près Chambéry], 30 July 1906 (1. fl), Chabert s.n. (BM).

BELGIUM. Namur: entre Doisches et Petit-Doisches contre la frontière française, au SW du Baquet, 16 July 1977 (fl), Duvigneaud 77B642 (H).

GERMANY. Rheinland Pfalz: Zweibrücken, n.d., Herb. Ekart/Irmisch s.n. (JE). Baden-Wurttemburg: [Schwabischen Alpen] Donstetten, August 1875 (fl \& fr), Kemmler s.n. (FR).

SWITZERLAND. Valais: Champéry, 4 September 1881 (fl), Lacaita s.n. (BM). Zürich: Affoltern, July 1902 (fl), Schinz s.n. (FR). St. Gallen: zwischen Litzibach und Vilters, $c .500$ m, 8 July 1951 Büel s.n. (BM, ZT*).

AUSTRIA. Salzburg: bei Hellbrun, 26 August 1913 (fl), Fröhlich s.n. (BM). Steiermark: ad vicum Maria-Trost prope urbem Graz, inter parentes, c. 430 m, July 1911 (fl), Fröhlich in Hayek, Fl. stir. exs. 1199 (BM, GZU, H).

The above description covers the range of variation in this hybrid, which becomes increasingly difficult to recognize as it approaches each parent in form. The typical $\left(\mathrm{f}_{1}\right)$ form has incomplete subsidiary stem lines, rather broadly oblong leaves with intermediately dense venation and laminar glands, oblong sepals with eroded-apiculate apex, and capsule vittae (both dorsal and lateral) linear. The chromosome counts of 48 and 40 were, presumably, the results respectively of the fertilization of an unreduced embryo sac and a back-cross from that to another unreduced embryo sac.

$5 x$ b. Hypericum $\times$ desetangsii nothosubsp. carinthiacum (A. Fröhl.) N. Robson [in B.S.B.I. News, no. 49: 50 (1988) in adnot.] in Wisskirchen \& Haeupler, Standardliste Farn- $u$. Blütenpfl. Deutschl.: 268 (1998); Lihová, Mártonfi \& Mártonfiová in Caryologia 53: 127 (2000). Type as for H. × carinthiacum A. Fröhl.

Fig. 9, Map 15.

5. H. perforatum L. $\times$ 1b. H. maculatum Crantz subsp. maculatum
H. maculatum subsp. typicum A. Fröhl. × perforatum L., A. Fröhl. in Sitzungsber. Kaiserl. Akad. Wiss., Math.-Naturwiss. Kl. 120(1): 557 (1911); in Öesterr. Bot. Z. 63: 14 (1913).

H. $\times$ carinthiacum A. Fröhl. in Mitt. Naturwiss. Vereins Steiermark 51:228 (1915). Fröhlich (1913) listed a series of localities in Carinthia where this hybrid was found, but did not designate a type either there or in his 1915 paper. See $5 x b a . H . \times$ desetangsii nothosubsp. carinthiacum nothoforma maculatiforme for lectotype.

H. $\times$ desetangsii nothomorph. carinthiacum (A. Fröhl.) N. Robson in Repert. Spec. Nov. Regni Veg. 74: 23 (1967), in Tutin et al., Fl. Europaea 2: 269 (1968); in Watsonia 9: 203 (1972).

Stems almost completely 4-lined to 2 -lined. Leaves broadly ovate or broadly elliptic to ovate-oblong; tertiary venation dense to lax; pale laminar glands very few. Sepals broadly elliptic to linear-lanceolate, acute to acuminate, entire or \pm eroded-denticulate to (glandular-) subfimbriate. Petals with black laminar glands rather numerous to few, mostly linear to mostly punctiform, or absent, black marginal glands present. Capsule with vittae all linear, dorsal and lateral, oblique, the latter regular or sometimes irregular. $2 n=24,40[48,56$ experimentally] (see below).

Habitat range of the parents?

The above description covers both triploid and pentaploid hybrids with both varieties of subsp. maculatum. As regards these hybrids, Noack (1939) found the triploid to be intermediate between the parents, but could not distinguish the pentaploid from pure $H$. perforatum. Mártonfi et al. (1996b), on the other hand, were able to distinguish the pentaploid, and thus indirectly confirmed Fröhlich's $(1913,1915,1960)$ recognition of two distinct forms of this hybrid. Seeds obtained from a wild-collected pentaploid plant yielded $5 \times$ $2 \mathrm{n}=40,5 \times 2 \mathrm{n}=48$ and $3 \times 2 \mathrm{n}=56$ plants (Lihová, Mártonfi \& Mártonfiová, 2000). 
5xba. Hypericum $\times$ desetangsii nothosubsp. carinthiacum nothoforma maculatiforme (A. Fröhl.) N. Robson in Wisskirchen \& Haeupler, Standardliste Farn-u. Blütenpfl. Deutschl.: 269 (1998). Type as for $H$. $\times$ carinthiacum forma maculatiforme A. Fröhl.

Map 15.

H. quadrangulum var. erosum Schinz in Bull. Herb. Boissier II, 3: 21, 22 (1902). Type: Switzerland, Zürich, Dreiländer Stein an der Hohe Rone, 31 July 1902 (fl), Schinz s.n. (Z!-lectotype, selected here - see also Mártonfi et al., 1999: 340). Fröhlich (1911) raised Schinz's taxon to subspecific rank in $H$. maculatum and later (1913, 1915) reduced the combination to a synonym of $H$. maculatum subsp. obtusiusculum (Tourlet) Hayek. All the specimens cited by Schinz, however, have proved to be hybrids belonging to the above nothoforma.

H. quadrangulum subsp. erosum (Schinz) Schinz in Vierteljahrsschr. Naturf. Ges. Zürich 49: 240, 241 (1905). Type as for $H$. quadrangulum var. erosum Schinz.

$H$. maculatum Crantz $\times$ perforatum $\mathrm{L}$. forma sub-maculatum in Oesterr. Bot. Z. 63: 14 (1913).

H. $\times$ carinthiacum forma maculatiforme A. Fröhl. in Mitt. Naturwiss. Vereins Steiermark 51: 229 (1915); Guşul. \& Nyár. in Săvul., Fl. R. P. Roman. 4: 46 (1956). Type: Austria, Carinthia, Nordhänge der Golitza südlich Rosenbach, c. 800 m, 16 August 1911 (fl), Fröhlich GZU 16301 (GZU!-lectotype, selected here).

H. perforatum subsp. latifolium var. obscurum O. Schwarz in Drudea 5: 61 (1965), nom. illegit. (Art. 37).

Stems with subsidiary lines almost complete though much less prominent than principal lines, i.e 4-lined. Leaves ovate to \pm broadly elliptic or elliptic-oblong, with tertiary reticulation dense, quite visible. Sepals ovate to lanceolate or linear-oblong, rounded or obtuse to finely apiculate or acute, entire or finely denticulate, usually black-glandular-punctate. $2 \mathrm{n}=24$ (Noack, 1939).

SCOTLAND. Moray: Boat-of-Garten, station yard, 4 August 1978 (fl), McCallum Webster 19460 (BM). Argyll: head of Loch Feochan, 11 July 1994 (fl), B.H. Thompson s.n.(BM); Kintyre, Skipness, 31 July 1899 (fl), Somerville s.n. (BM). Lanark: Bothwell Castle, 26 July 1987 (fl), Dickson s.n. (GL).

NORWAY. Hordaland: Hardanger, Strandebarm, 10 July 1940 (fl), Lillefosse s.n. (BM, K, O*).

FRANCE. Loire: St. Miedard, July 1895 (fl), Anthelme s.n. (H). HteSavoie: near Chambéry, above St. Jean Arvey, c. 600 m, 18 July 1954 (fl), De Wit 5368 (WAG).

GERMANY. Hessen: Grossherz, Vilbeler Wald, 12 July 1973 (fl), Dürer s.n. (FR); Kr. Alsfeld, Schnellhausen, Hahnberg, 8 July 1950 (fl), Hupke s.n. (JE). Thüringen: Erfurt, Chaussee, July 1931, Reinecke s.n. (JE).

SWITZERLAND. Jura: La Dôle, 1864 (fl), Favrat \& Barbey 77 pp. (K). Zug: Geissboden, c. 950 m, 19 July 1902 (fl), Schinz s.n. (Z). Schwyz: Aufsteig zum Rikliklosterli von Goldau aus, 8 September 1902 (fr), Schinz \& Brunies s.n. (Z). Zürich: Limmatal bei Herdern-Altstetten, c. 400 m, 3 August 1925, W. Koch s.n. (H).

AUSTRIA. Steiermark: bei Strassgang bis Graz, n.d. (fl \& fr), Fröhlich s.n. (BM, GZU); bei M.[aria] Trost, 10 August 1911 (fl), Fröhlich s.n. (BM, GZU). Niederösterreich: Berchtoldsdorf, July 1919 (fl), Fens? s.n. (K).

ROMANIA. Transylvania: in monte Transsilv., July, Schur s.n. (JE).

On the basis of specimens seen, nothoforma maculatiforme seems to be rarer than nothoforma perforatiforme.

5xbb. Hypericum $\times$ desetangsii nothosubsp. carinthiacum nothoforma perforatiforme (A. Fröhl.) N. Robson in Wisskirchen \& Haeupler, Standardliste Farn- u. Blütenpfl. Deutschl.: 269 (1998).

Map 15.

Hypericum perforatum [var.] $\beta$ latifolium Gaudin, Fl. helv. 4: 627 (1829); W. Koch in Röhling, Deutschl. Fl. 3rd ed. 5: 349 (1839), Syn. fl. germ. helv., 2nd ed.: 146 (1843), Syn. deut. schweiz. Fl.

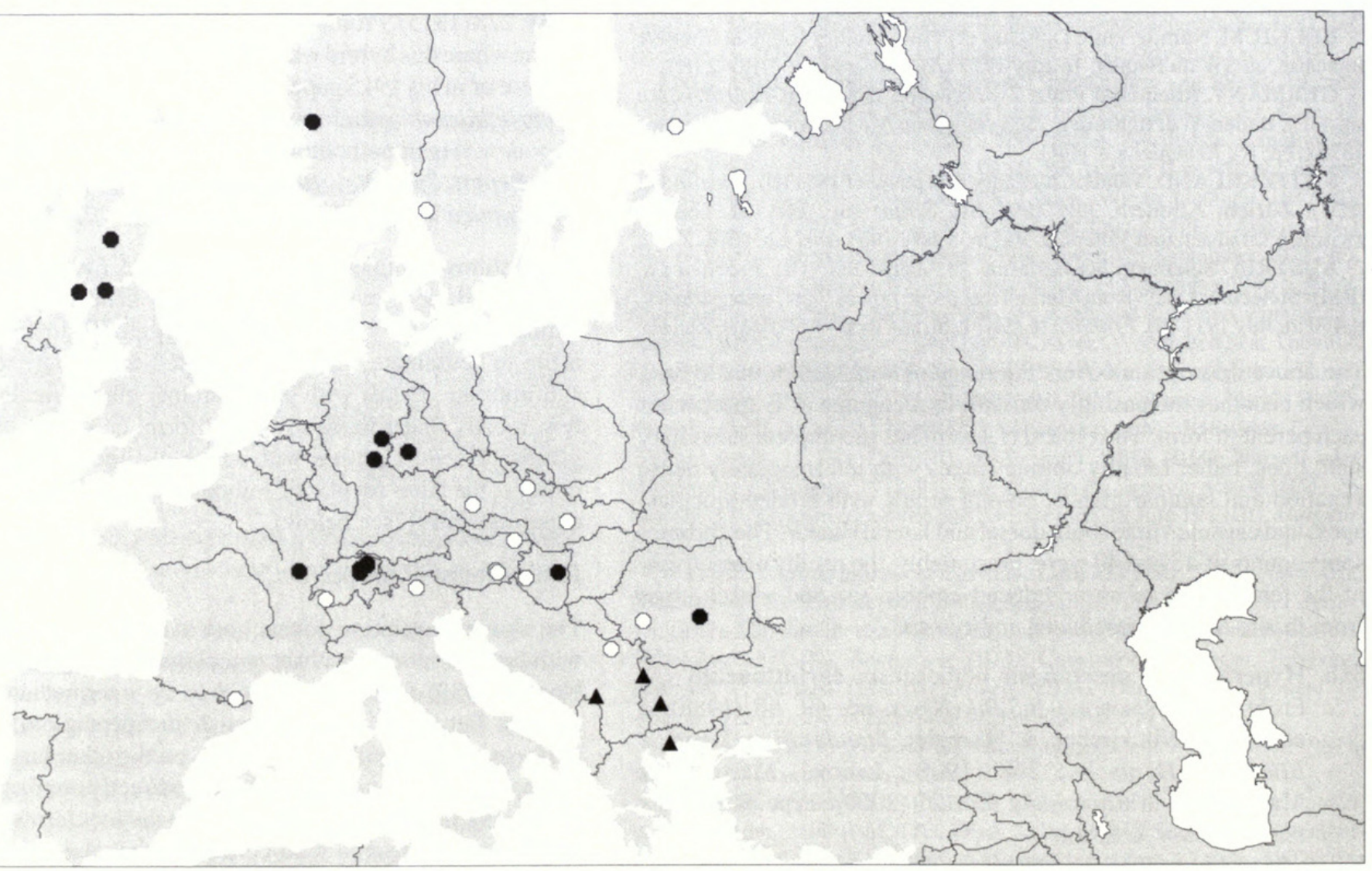


2nd ed: 155 (1846), pro parte omnes quoad typum; Neilr., Fl. Nieder-Oesterr: 826 (1859); Rouy in Rouy \& Fouc., Fl. France 3: 333 (1896); Hegi, Ill. Fl. Mitt.-Eur. 5(1): 528 (1925); Guşul. \& Nyár. in Sävul., Fl. R. P. Roman. 4: 29 (1956); Jordanov \& Kož in Jordanov, Fl. R. P. Bulg. 4: 261 (1970); N. Robson in Cullen et al., Eur. gard. fl. 4: 60 (1995), in Wisskirchen \& Haeupler, Standardliste Farn-u. Blütenpfl. Deutschl.: 270 (1998). Type: Switzerland, no precise locality, Gaudin s.n. (LAU-holotype). The specimens labelled var. or subsp. latifolium that I have seen all have partly developed subsidiary stem lines and otherwise also agree with Fröhlich's description of $H$. carinthiacum f. perforatiforme and specimens identified by him as such. Other than Koch himself, all the above authors cited this taxon as $H$. perforatum var. latifolium Koch; but Koch cited Gaudin, to whom this name should be credited. I have not seen Gaudin's type; but never having seen an undoubted $H$. perforatum with broad sepals, I assume that it belongs here.

H. perforatum var. platycalyx Čelak., Prodr. fl. Böhmen: 520 (1875). Type: Czech Rep., Středočeský, Jungbundzlau [Mladá Boleslav], Celakovský (PR?). Čelakovsky cited ' $\gamma$ latifolium Koch' after his ' $\gamma$ platycalyx'; the type must therefore be that of var. latifolium Koch, i.e. var. latifolium Gaudin (see above). Celakovsky's 'type' is not in PR (Dr B. Skočdopolová, in litt. 2001). The only Hippelli specimens from Jungbundzlau in that herbarium are of subsp. veronense, whilst the only one labelled 'var. platycalyx' (15 July 1910) by Celakovsky is subsp. perforatum.

H. perforatum [var.] $\beta$ latifolium subvar. lineolatum Rouy in Rouy \& Fouc., Fl. France 3: 333 (1896). Type as for 'H. lineolatum Jord. pro parte'. Rouy 'split' Jordan's type of $H$. lineolatum between his subvar. lineolatum of var. vulgare and subvar. lineolatum of var. latifolium. As Jordan's specimen is the type of var. vulgare, the subvar. of var. latifolium becomes typeless.

H. perforatum subsp. latifolium (Gaudin) A. Fröhl. in Sitzungsber. Kaiserl. Akad. Wiss., Math.-Naturwiss. Kl. 120(1): 525, f. 3a (1911), in Mitt. Naturwiss. Vereins Steiermark 51: 240 (1915); Hegi, Ill. Fl. Mitt.-Eur. 5(1): 528 (1925); Hayek, Prodr. Fl. Pen. balc. 1: 533 (1925); Stjep.-Vesel. in Josifovć, Fl. Srbije 3: 119 (1972).

H. perforatum subsp. latifolium forma dentatum A. Fröhl. in Sitzungsber. Kaiserl. Akad. Wiss., Math.-Naturwiss. Kl. 120(1): 527, f. 3b, c (1911). Type: Austria, Steiermark, Plesch bei Gratwein, 5 September 1909 (fl \& fr), Fröhlich GZU 16341 (GZU!-lectotype, selected here).

$H$. perforatum subsp. latifolium forma fimbriatum A. Fröhl. in Sitzungsber. K. Akad. Wiss., Math.-Naturwiss. Kl. 120(1): 529, f. 4(1911). Type: Austria, Steiermark, Mühlbachkogel bei Gratwein, c. 1000 m, 18 July 1909 (fl), Fröhlich GZU 16345 (GZU!lectotype, selected here).

H. maculatum Crantz $\times$ perforatum $\mathrm{L}$. forma sub-perforatum $\mathrm{A}$. Fröhl. in Oesterr. Bot. Z. 63: 14 (1913).

H. $\times$ carinthiacum forma perforatiforme A. Fröhl. in Mitt. Naturwiss. Vereins Steiermark 51: 229 (1915); Guşul. \& Nyár. in Săvul., Fl. R. P. Roman. 4: 46 (1956). Type: Austria, Kärnten, Drauwiesen bei M.[aria] Elend, 16 July 1911 (fl), Fröhlich GZU 16300 (GZU!-lectotype, selected here).

H. maculatum subsp. desetangsiiforme A. Fröhl. in Mitteil. Naturw. Ver. Steierm. 51: 219 (1915); Hegi, Ill. Fl. Mitteleuropa 5(1): 518 (1925). Type: Austria, Steiermark, bei Graz, Jüdendorf, July 1913 (fl), Fröhlich GZU 16155 (GZU!-lectotype, selected here).

H. maculatum subsp. desetangsiiforme var. aporosum A. Fröhl. in Mitteil. Naturw. Ver. Steierm. 51: 220 (1915). Type: Austria, Steiermark, bei Maria Trost, July 1913 (fl), Fröhlich GZU 16171 (GZU!- lectotype, selected here).
H. $\times$ desetangsii nothomorph perforatiforme (A. Fröhl.) N. Robson in Bull. Br. Mus. (Nat. Hist.), Bot. 8: 168 (1981); Mártonfi, Repčak \& Mihoková (1996b).

H. carpaticum Màrtonfi in Folia Geobot. 36: 374 (2001). Type: Slovakia (E.), [Volovské vrchy Mts] village of Pracovce, path near dextral feeder of Hrelikov potok brook, 27 July 1995 (fl), Màrtonfi 2012 (BRA-holotype). Mártonfi (2001: 378) describes this pentaploid population as 'most likely of hybridogenous origin, with $H$. perforatum and $H$. maculatum [i.e. subsp. maculatum] as parents.' He claims, however, that it 'was stabilized and sufficiently reproductively isolated from its parents due to inherited apomixis' to allow it to be treated as a species. On the basis of his description and illustrations, however, it seems to be no more distinct from the rest of nothoforma perforatiforme than are parts of that taxon (e.g. 'subsp. desetangsiiforme'). It seems most appropriate, therefore, to include it in nothoforma perforatiforme.

Stems with incomplete and scarcely prominent subsidiary lines or 2lined. Leaves elliptic to rather narrowly oblong, with tertiary reticulation denser than in $H$. perforatum but obscure. Sepals elliptic to lanceolate and acute to finely acuminate or oblanceolate and apiculate, sometimes eroded-denticulate, usually black-glandularstriate to -punctate, those on main stems sometimes becoming markedly depressed ('desetangsiiforme'). $2 \mathrm{n}=40$ (Noack, 1939, as $H$. perforatum $\times$ quadrangulum; Mártonfi et al., 1996a, $b$; Lihová, Mártonfi \& Mártonfiová, 2000 [also 2n=48, 56 experimentally].

SWEDEN. Göteborg: Ringön, 23 July 1957 (l. fl), Blom s.n. (BM, GB*). FINLAND. Uusimaa: Nylandia, par. Kyrkslätt, Tero in pago Österby, 8 August 1907 (fl), H. Lindberg Pl. Fin. Exsicc. 806 (K).

FRANCE. Hautes Pyrenées: between Gèdre and Gavarnie, 900 m, 21 July 1922 (fl), Hutchinson, Matthews \& Riley 14 (K).

GERMANY.Mecklenburg-Pommern: Dalwitz, 1864 (fl), Kokeils.n.(K)

CZECH REPUBLIC. Bohemia, Jihočeský Kraj: *in silvis Novosedlecký revir prope opp. Písek, August 1941, M. Deyl PR 164950 (PR). Moravia, Severomoravský Kraj: Hohenstadt [Zabreh], bei Unterheinzendorf, July 1933 (fl), Hruby s.n. (H).

SLOVAKIA. Košický Kraj: Prakovce, 3 August 1993 (fl), Mártonfi 1452 (BM); *ZZylinský Kraj: Kysuce, near Nová Bystrica, c. 600 m, 7 July 1959, Futák s.n. (SAV).

AUSTRIA. Steiermark: Mühlbachkogel, bei Gratwein, 25 July 1910 (fl), Fröhlich GZU 16338 (GZU). Kärnten: [Cult. ex] Karawanken, nördlich der Goliza, n.d. (fl), Fröhlich GZU 215 (GZU). Niederösterreich: in hort. bot. Vindobon., n.d. (fl), Kerner in Fl. Exs. Austro-Hung. 3649 (BM, K).

SWITZERLAND. ? : Pont d'Of, 16 July 1856 (fl), Depierre s.n. (BM).

ITALY. Botzen [Bolzano]: Ritten, n.d. (fl), Hausmann s.n. (BM, IBF*).

HUNGARY. *Comit. Vas: 'Tótszgyörgy', 12 July 1882, Borbás BP 261470 (BP).

ROMANIA. Transylvania: Adamsdorf [Adamos], bei Bruñes, 15 June 1873 (fl), Schur 12138 (BM).

BOSNIA. Igman planina, am Veliko Palje, 14 June 1908 (fl), Ualy s.n. (K).

Specimens apparently correctly identified as $H$. perforatum var. latifolium K. Koch are indistinguishable from those keying out to $H$. $\times$ carinthiacum var. perforatiforme; and the distribution of the $H$. perforatum variety does not exceed that of $H$. maculatum subsp. maculatum. I have therefore concluded that it, too, is a manifestation of this hybrid, not a form of $H$. perforatum itself. In addition, the voucher specimen for the count of $2 \mathrm{n}=40$ by Mártonfi et al. (see p. 105) agrees with the description and authentic specimens of $H$. maculatum subsp. desetangsiiforme A. Fröhl., which I have therefore also included in the synonymy of nothoforma perforatiforme.

5xc. Hypericum $\times$ desetangsii nothosubsp. balcanicum N. Robson, nothosubsp. nov. Type: Greece, E. Makedhonia, Nom. Serron, 
Mt Vrondous, near the EOS ski centre, 1700-1800 m, 26 July Map 15.

1981 (fl), Farsakoglou, Franzén \& Strid 19521 (C!-holotype).

\section{H. maculatum Crantz subsp. immaculatum (Murb.) A. Fröhl. $\times$} perforatum $\mathrm{L}$.

A nothosubsp. carinthiacum foliis sessilibus plerumque latioribus apice interdum acutis basin interdum cordatis, glandulis laminaribus petalorum pellucidis haud nigris, differt.

Leaves sessile; lamina broadly ovate to elliptic-oblong, apex rounded to acute, base cuneate to cordate-amplexicaul. Petals without black laminar glands.

SERBIA. Kosovo: Bertiscus, riv. Sušica prope Pré (Ipek) [Peč], c. $800 \mathrm{~m}$, 12 July 1933 (fl), Rechingerf. \& Scheffer 782 (BM).

BULGARIA. Samokov: Vakarel, c. 750 m, 16 July 1945, Kitanov 370 (JE). Predbalkan: Ostabhang des Midshur [Midžor], 4 September 1958 (fr), Meyer 1171 (JE). Dobruja: Süddobrudsha, Varna, Weg vom Strand zum Aladsha Monastir, 11 August 1958 (fl \& e. fr), Meyer 414 (JE).

GREECE. Makedhonia (E.): Nom. Kavalas, Mt Pangaion, summit area, Tsekour Madra, 1550-1750 m, 26 July 1977 (fl \& e. fr), Papanicolaou 411 (C).

These specimens are intermediate in form between $H$. perforatum and $H$. maculatum subsp. immaculatum and would therefore appear to be hybrids. Nevertheless, the Bulgarian specimens (with the possible exception of Kitanov 370, which I have not seen recently) and one of the Greek ones have apparently ripe or immature fruit, which, if they are triploids, would be unlikely. The type and the Kosovo specimen, however, are convincingly intermediate and would seem to be true hybrids.

5xx. Hypericum $\times$ medium Peterm., Fl. lips. excurs.: 563 (1838); Rchb., Icon. fl. germ. helv. 6: f. 5178 (1842-1844); Rouy in Rouy \& Fouc., Fl. France 3: 337 (1896); N. Robson in Stace, Hybridization and the flora of the Br. Isles: 166 (1975). Syntypes: Germany, Leipzig, ad pagum Leutsch, July-August (fl), Petermann s.n. (LZ).

\section{H. perforatum L. $\times$ 4. H. tetrapterum $\mathrm{Fr}$.}

H. $\times$ sparsiflorum Schur in Verh. Naturf. Vereins Brünn 15(2): 158 (1877). Type: Moravia, bei Bisterz auf der Mnischihora, im Punkwathale nächst Brünn, July-August 187-, Schur s.n. (BRNU? or LW?).

H. perforato-acutum sec. O. Kuntze \& Focke fide Rouy \& Foucaud, Fl. France 3: 337 (1896).

H. acutum $\times$ perforatum; A. Fröhl. in Sitzungsber. Kaiserl. Akad. Wiss., Math.-Naturwiss. Kl. 120(1): 592 (1911).

H. $\times$ dubioides Druce in Bot. Soc. Exch. Cl. Br. Isles 8(5): 868 (1929), nomen. Only the formula $H$. perforatum $\times$ quadrangulum was cited.

Icon: Rchb., Icon. fl. germ. helv. 6: f. 5178 (1842-1844).

Intermediate between the parents Stems without or with partial subsidiary lines. Leaves oblong to elliptic-lanceolate with dense to lax, rather obscure reticulate venation; pale laminar glands relatively few, varying in size. Sepals oblong to lanceolate, acuminate, without black glands. Petals without or with linear to striiform black laminar glands. Capsule with shortened lateral vittae.

This hybrid is rare, on account of the differing habitats of its parents, but could occur anywhere where their distributions overlap. Fröhlich (1911: 593) cites three German localities, but I have seen only the two French specimens, the third (Romanian) one having been determined by Dr Mártonfi.
FRANCE. Jura: Beauvoisin près Chaussin, 6 July 1853 (fl), Michalet s.n. (K); Chaussin, September 1873 (fr), Michalet s.n. (CLF).

GERMANY. Leipzig. See type.

CZECH REP. Moravia. See type of $H . \times$ sparsiflorum Schur.

ROMANIA. Transylvania: *Comit. Hunyad., Pareng mts, in Bordi, 21 June 1906, Jávorka BP 11535 (BP).

\section{5xxx. (Hypericum perforatum L. $\times$ H. maculatum Crantz $) \times \mathbf{H}$. tetrapterum Fr.}

5x. H. $\times$ desetangsii Lamotte $\times 3 . H$. tetrapterum Fr.

(H. maculatum Crantz $\times H$. perforatum L.) $\times H$. acutum Moench sensu A. Fröhl. in Sitzungsber. Kaiserl. Akad. Wiss., Math.Naturwiss. Kl. 120(1): 591, f. 13 (1911).

Approaching $H$. tetrapterum in habit. Stems with wider subsidiary lines than $H$. perforatum $\times$ maculatum. Leaves broadly ovate, almost semi-amplexicaul, with laxer reticulation venation and quite densely and finely pale-gland-dotted. Inflorescence more compactly flowered. Flowers smaller than in the hybrid parent, c. $20 \mathrm{~mm}$ in diam. Sepals relatively broadly ovate, acuminate; laminar glands all or mostly pale, striiform to punctiform. Petals darker yellow than in $H$. tetrapterum, like those of the hybrid parent, with pale glands only. Stamens c. $2 / 3 \times$ petals. Ovary broadly ovate (no fruit seen).

Switzerland (Schwyz, St. Gallen).

SWITZERLAND. Schwyz: Roblosen, near Einsiedeln, 900 m. Thellung s.n. (Z*). St. Gallen: Fürstenland, in den Senke östlich von Gründenwald bei Winkeln, 640 m, 2 August 1946 (fl), Koch 46/421 I (H).

Like $H . \times$ medium, this hybrid has parents with widely differing habitat requirements and must therefore be rare. The above data have been extracted mainly from Fröhlich's account (1911: 591).

Hypericum assurgens Peterm., Anal. Pflanzenschl. bot. Excurs. Leipzig: 67 (1846), which Petermann himself published as a synonym of his $H$. perforatum var. petiolatum (described on the same page), was claimed by Otto Kuntze (Flora 63: 293, 1880) to be the unlikely hybrid $H$. humifusum $\times$ perforatum. On the basis of the Petermann specimen named $H$. assurgens in W!, I regard this plant as a rather long-petioled form of $H$. perforatum subsp. perforatum (see p. 89).

6. Hypericum attenuatum Fisch. ex Choisy, Prodr. monogr. Hypéric.: 47, t. 6(1821), in DC., Prodr. 1: 548 (1824); Turcz., Fl. Baical.-Dahur. 1: 251 (1842); Ledeb., Fl. ross. 1: 448 (1842); Maxim., Primit. fl. amur: 65 (1859), in Bull. Acad. Imp. Sci. Saint-Pétersbourg 27: 433 (1882), Mél. Biol. Bull. Acad. Imp. Sci. Saint-Pétersbourg 11: 166 (1882); Regel, Tent. fl. ussuri: 33 (1861); Hance in J. Bot. 12: 259 (1874), op. cit. 16: 104 (1878); Franchet, Pl. david. 1: 56 (1884); Forbes \& Hemsley in J. Linn. Soc. Bot. 23: 72 (1886); Diels in Bot. Jahrb. Syst. 29: 476 (1901); Freyn in Oesterr. Bot. Z. 52: 17 (1902); Komarov, Fl. Manshur. 3: 43 (1905); H. Léveillé in Bull. Soc. Bot. France 54: 594 (1908); Nakai, Fl. kor. 1: 95 (1909), 2: 453 (1911); Komarov \& Klob.-Alis., Opred r. Dal'nevost. kr. 2: 747, t. 232 f. 2 (1932); Kitagawa, Lineament. Fl. Mandshur: 317 (1939); Gorschkova in Shishkin \& Bobrov, Fl. URSS 15: 236 (1949); Komarov, Fl. Manchzh. 5: 48 (1950); Y. Kimura in Nakai \& Honda, Nova fl. jap. 10: 213 (1951), in J. jap. Bot. 34: 323 (1959); Kitamura \& Murati in Acta Phytotax. Geobot. 20: 197 (1962); Noda, Fl. N. E. Prov. (Manch.) China: 794 (1971); Anon., Iconogr. Cormoph. Sinicae 2: 875, f. 3480 (1972); Wu C.-J. in Fl. Intramongol. 4: 91, t. 42 ff. 1-3 (1979); Lee, T. B. Ill. Fl. Korea: 545 cum f. (1989); 


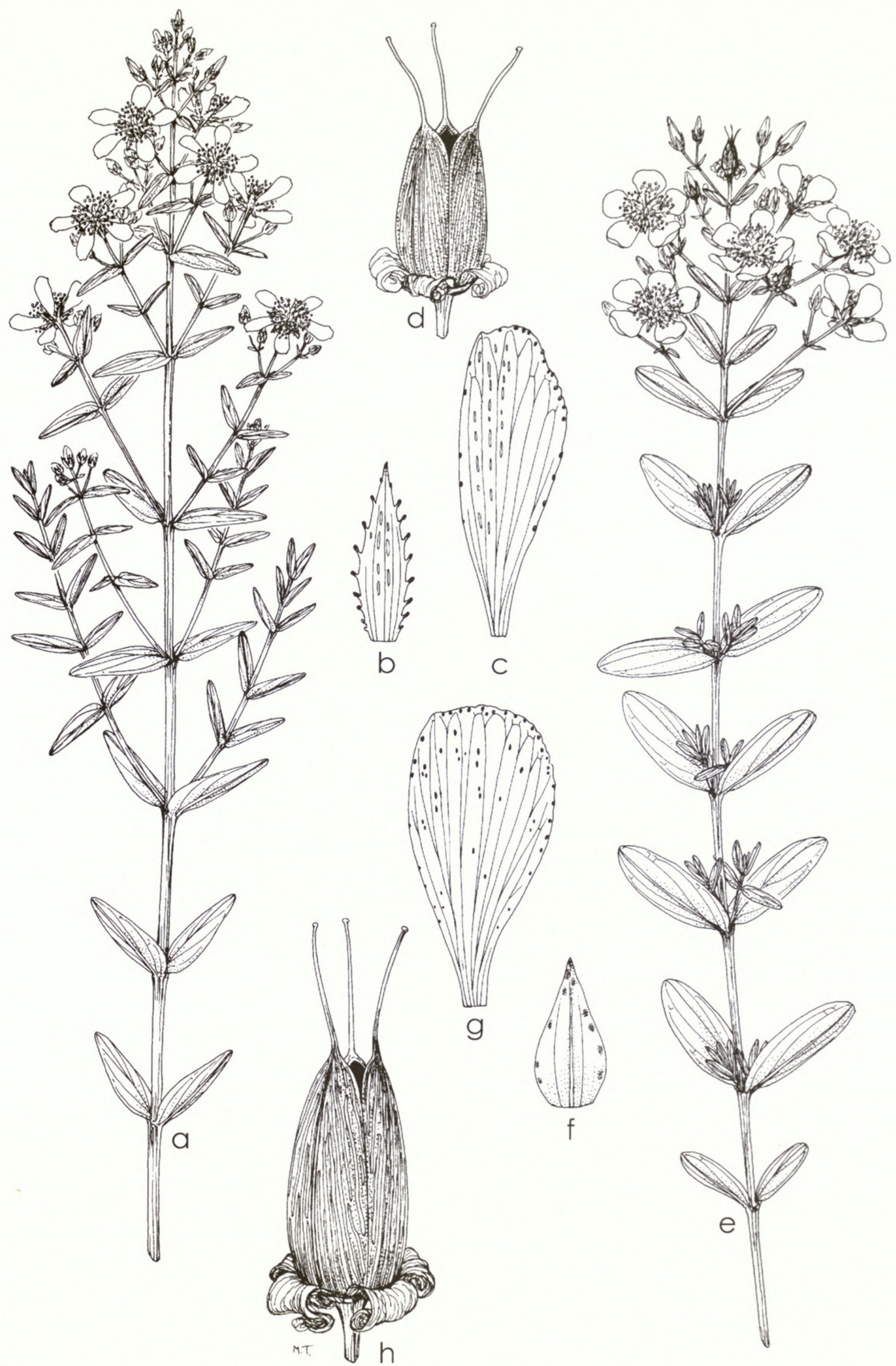

Fig. 10 A. H. elegans: (a) habit; (b) sepal; (c) petal; (d) capsule. B. H. attenuatum: (e) habit; (f) sepal; (g) petal; (h) capsule (a, e $\times 2 / 3$; c, g, h $\times 4$; rest $\times$ 8). A. (a-c) Bločky s.n.; (d) Launert s.n. B. (e) Kang 57; (f, g) Campbell s.n.; (h) Kang 68. 


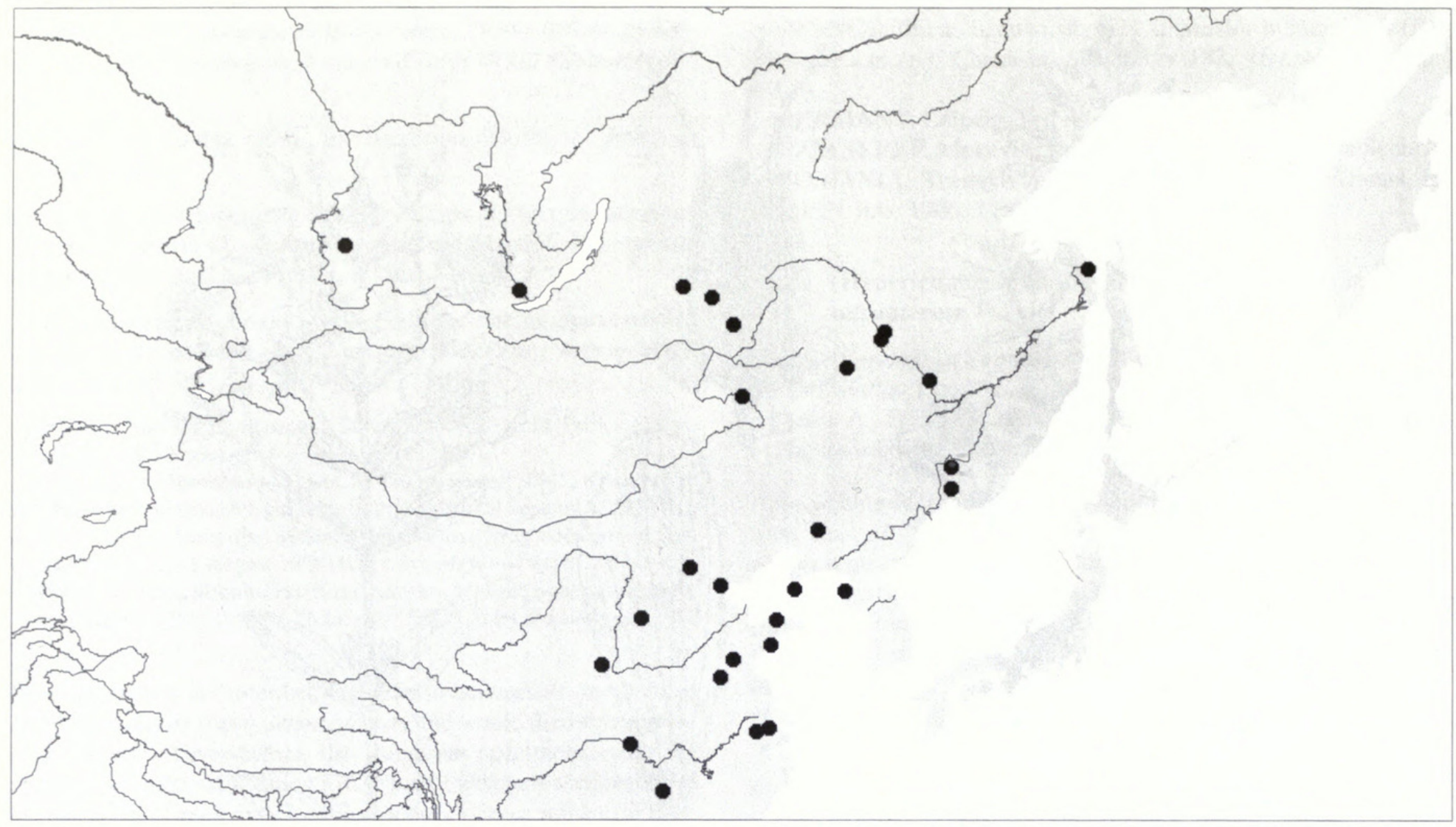

Map 16 6. H. attenuatum

Li Xiwen in Fl. R. P. Sinicae 50(2): 69, t. 15 ff. 5-8 (1990); N. Robson in Cullen et al., Eur. gard. fl. 4: 60 (1995); non $H$. attenuatum Link (1822) (= H. canariense L.). Type: Russia, Irkutsk, Dauria prope Macarova in valle granitica et alibi, n.d. (fl), Fischer s.n. (G-DC-holotype, microfiche!; P!-isotype).

Fig. 10, Map 16.

H. perforatum var. confertiflorum Debeaux in Actes Soc. Linn. Bordeaux 31: 130 (1876), Florule du Tché-foû: 35 (1877) ['confertiflora']; Maxim. in Bull. Acad. Imp. Sci. SaintPétersbourg 27: 432 (1882), Mél. Biol. Bull. Acad. Imp. Sci. Saint-Pétersbourg 11: 166 (1882). Type: China, Shandong, Tchéfou [Chefoo=Yantai], 12 July 1860 (fl \& e. fr), Debeaux Exp. de Chine 60. (P!-lectotype, selected here). Although this name was adopted by me as the provisional basionym of the Chinese subspecies of $H$. perforatum, and I determined some specimens of it as $H$. perforatum subsp. confertiflorum, a syntype borrowed from $\mathrm{P}$ clearly belongs to $H$. attenuatum, a species for which the epithet confertiflorum is appropriate.

?H. kamtschaticum var. senanense sensu Y.N. Lee, Fl. kor. 3rd ed.: 232, f. 685 (1998).

Icones: Wu C.-J. in Fl. Intramongolica 4: 92, t. 42 ff. 1-3 (1979); Li Xiwen in Fl. R. P. Sinicae 50(2): 68, t.15 ff. 5-8 (1990).

Perennial herb $0.1-0.45(-0.7) \mathrm{m}$ tall, erect from rootstock or creeping rhizomatous base, with stems numerous to few, caespitose, much branched. Stems 2-lined, with black punctiform and striiform glands on lines and often sparsely (reddish or black) elsewhere; internodes (10-)15-40 mm, usually exceeding leaves. Leaves sessile; lamina (8-)15-31(-38) $\times(3-) 5-12(-15) \mathrm{mm}$, elliptic or elliptic-oblong to oblanceolate or rarely ovate, paler beneath, chartaceous; apex obtuse to rounded, margin entire, plane, base subcordate to cuneate; venation: 2 pairs of main laterals from lower sixth of midrib, tertiary reticulation dense but often rather obscure and apparently lax; laminar glands punctiform, small, pale and black, few or scattered, mainly distal; intramarginal glands black, spaced. Inflorescence many- to few(rarely 1-) flowered from 1-4 nodes, sometimes with flowering branches from up to 4 nodes below, the whole cylindric to pyramidal; pedicels (1.5-)3-4 mm; bracts and bracteoles 3.5-6.5 $\mathrm{mm}$ long, oblong-elliptic, entire. Flowers 13-20(-25) $\mathrm{mm}$ in diam., stellate; buds ovoid, subacute to acute. Sepals 5, unequal to subequal, (3.5-)5-10 × 1-4 mm, erect in bud and fruit, triangularovate to lanceolate, acute to subacuminate, entire; veins 5-7, distally branched; laminar glands pale, striiform to punctiform and black, punctiform, scattered, rather sparse or rarely absent; intramarginal and marginal glands black, punctiform, sparse, distal. Petals 5, golden? yellow, tinged red in bud, 8-12 $\times$ 4-7 $\mathrm{mm}, 2.4-3 \times$ sepals, oblong-obovate, asymmetric, entire, laminar glands black, punctiform to striiform, scattered, marginal glands black, distally dense. Stamens c. 90, '3'-fascicled, longest 8-10 $\mathrm{mm}$, c. $0.7-0.8 \times$ petals; anther gland black. Ovary 3-locular, 2.5$3.5 \times 2-3 \mathrm{~mm}$, narrowly ovoid; styles 3 , free, $4-4.5 \mathrm{~mm}, 1.3-1.6$ $\times$ ovary, widely spreading; stigmas narrowly capitate. Capsule (4-)6-10 × 2-6 mm, 2-3 × sepals, broadly ovoid or oblong-ovoid to narrowly conic; valves densely longitudinally vittate, occasionally with a few black longitudinal glandular streaks. Seeds dark? brown, c. $0.7 \mathrm{~mm}$, cylindric, slightly carinate and apiculate, not appendiculate; testa finely linear-foveolate. $2 n=16$ (Probatova \& Sokolovskaya, 1986).

Fields, pastures, steppes, grassy and dry stony slopes, pebble shores, forest margins and clearings; China: s.l. (Liaoning) - 2000 m (Guizhou); Russia.

Russia (E. Siberia: Angara-Sayan, Dauria, Lena-Kolyma; Far East: 
Zeya-Bureya, Uda, Ussuri, Sakhalin? ${ }^{6}$ ), Mongolia, China (Nei Mongol, Heilongjiang and Jilin south to Guizhou, N. Guangxi and Guangdong), Korea.

RUSSIA. Angara-Sayan: Inter Irkutsk et Jenisseisk, ad fl. Angara (Tunguska super.) pro pagum Padun, 1867 (fl), Czekanowski s.n. (BM); Prov. Irkutsk, distr. Balagansk, prope Bashejewskoje, 11 July 1904 (fl), Malzew 1919 (BD, H). Dauria: Chita distr., Priiskovaya stn, valley of R. Nercha, NE slope of Mt Krasnyy mys, 28 June 1952 (fl), Sergievskaya \& Obolentsev s.n. (H); Nertschintsk, 1899 (fl), Karo 143 (BD, BM, H, JE, K). Lena-Kolyma: see type. Zeya-Bureya: Zejskaja Pristan am Zeaflusse, July 1899 (fl), Karo 359 (BM, H, JE, K); Blagowjestschensk in Amurgebeite, 1898 (fl), Karo 224 (BM, JE). Uda: present (fide Gorschkova, 1949: 237). Ussuri: Prov. Amurensis, fluvium Amur circa stationem Radde, 25 June 1895 (fl), Komarov Fl. Man. 1092 (BM, K). Sakhalin? (see footnote 6).

MONGOLIA. Khalka Gol, 26 July 1902 (fl \& e. fr), Campbell s.n. (BM); Ourato, Oulachan occid., August 1882? (fl), David 1944 (K).

CHINA. Nei Mongol: Solon Qi, Honggolj, 17 August 1956 (fr), Liou T.N. et al. 8250 (NAS, PE); Ergun Qi, 720-850 m, 9 July 1951 (fl \& fr), Wang Z. et al. 1197 (PE). Heilongjiang: Ningan Xian, Jingpo Hu, 20 July 1975 (fl), Fu P.Y. et al. 3327A (IFP); Yilan Xian, Weiken R., 7 August 1959 (fl), Chang, $Y u$ Liang et al. 1971 (IBSC). Jilin: Jilin Shi, Longtan Shan, 8 September 1956 (fr), Chang Y.L. et al. 911 (KUN, PE); Jiutai Xian, Tumenling Village, $300 \mathrm{~m}$, 28 August 1950 (fr), Fu P.Y. et al. 2027 (IBSC, PE); Mukden to Kirin, Tangho-ko, Sungari R. to Hui-fa R., 1886 (fl), James s.n. (K). Liaoning: Chikuanshan, Tiehling, 250 m, 18 July 1930 (fl), Kung H.W. 648 (PE); near Mukden, Lao-yeh Ling and other hills, May-August 1886 (fl), James s.n. (K). Hebei: Neiqiu Xian, Xiaolingdi Village, 1600-1700 m, 21 July 1950 (fl \& fr), Liи Y. 13150 (NAS); Hsiaowutai Shan, 1500 m, 29 August 1913 (fr), Meyer 1376 (GH, K). Shanxi: Wutai Xian, Gengzhen Xiang, 2000 m, 19 July 1959 (fl \& fr), Kuan \& Chen 2433 (PE); Xiangning Xian, Guanwang Temple, 17 July 1960 (fl), Liu X.Y. 20863 (HNWP); Wenshui, S. of Hechiata, 14 August 1925 (fl), Keng 68(BMp, GH). Shaanxi: Schansi, 1500 m, 18 August 1935 (fl), Licent 12519 (GH); Shang Xian, 1060 m, 6 August 1952 (fl \& fr), Wang T.P. 16043 (PE); Mt Lao-y-san, Sciuz-scien, June 1897 (fr), Fr Hugh s.n. (BM). Gansu: fide Li Xiwen (1990). Shandong: Fei Xian, Meng Shan, 350 m, 12 July 1936 (fl \& fr), Cheo \& Yen 38 (GH); ibid., 20 July 1936 (fl \& fr), Cheo \& Yen 122 (BM); Wulian Xian, Wulian Shan, 20 July 1959 (fr), Cheo T.Y. et al. 5128 (NAS). Henan: Lushi Xian, Laochun Shan, 555 m, 4 August 1935 (fl), Liou K M. 4892 (PE); Xinyang Xian, Youhe Gongshe, 500 m, 18 July 1965 (fl), Chen \& Ming 14 (PE). Jiangsu: Wuxi, Hui Shan, 11 July 1956 (fl), Ting \& Wang 925 (NAS); Zhenze, Dong Shan, Huachuan Ling, 29 July 1958 (fr), Wu W.X. 3782 (IBSC). Anhui: Wuhu, 20 June 1941 (fl), Migo s.n. (NAS); Chu Xian, Langyashan, 2 August 1951 (fr), Huadong Working Stn 3148 (PE). Zhejiang: Jinhua Xian, 24 July 1927 (fl), Keng Y. L. 873 (NAS, PE). Fujian: Wuyi Shan, peak of Huanggang Shan, 2130 m, 20 July 1980 (fl), Wuyishan Exped. 80-0147 (IBSC). Jiangxi: Suichuan Xian, 1100 m, 22 September 1963 (fr), Yue J.S. et al. 4159 (IBSC); Julian Shan, n.d. (fl \& fr), Julianshan Forestry Farm 781088 (IBSC). Guangdong, Guangxi: fide Li Xiwen (1990). Hunan: Sangzhi Xian, Bamaoxi Gongshe, 1500 m, 3 July 1975 (fl), Li \& Shao 750126 (IBSC); Fenghuang Xian, Liantouyang Xiang, 600 m, 17 September 1988 (fl \& fr), Wuling Exped. 1209 (IBSC). Hubei: Ichang and immediate neighbourhood, 1885-1888 (fr), Henry 4157 (BM, GH, K); Wuchang, Luojishan, July 1932 (fr), Chung H. H. 9078 (A). Sichuan: Sintsin Hsien [Xinjin Xian], 600 m, 23 July 1938 (fr), Wang T.P. 8309 (PE). Guizhou: Hsing Shan, 2000 m, 11 October 1931 (fr), Steward et al. 536 (PE).

KOREA (N). Namp'o-Si: in herbidis Chinnampo [Namp'o], August 1906 (e. fr), Faurie 618 (BM).

Hypericum attenuatum is most closely related to $1 . H$. maculatum and 11. H. scouleri (respectively from western Eurasia and western North America), differing from both inter alia by the constantly 2lined stem, from $H$. maculatum by the acute sepals, and from $H$. scouleri by the gland-dotted petals. It would seem to be one diploid parent (with $H$. maculatum subsp. maculatum) of the amphidiploid H. perforatum.
Kitamura \& Murati (1962) sank the Japanese H. tosaense Makino (1903), with its f. insulare Y. Kimura (1951) and var. atumense (Y. Kimura)Y. Kimura (1959), and H. momoseanum Makino (1931) into $H$. attenuatum, but these taxa appear to be distinct from that species (see key, p. 67). See also Y. Kimura (1959), who included them all in an ' $H$. attenuatum Superspecies'.

7. Hypericum elegans Stephan ex Willd., Sp. Pl. 3: 1469 (1802); M. Bieb., Fl. taur-caucas. 2: 230 (1808), 3: 519 (1819); Poiret, Encycl. Suppl. 3: 701 (1814); Choisy, Prodr. monogr. Hypéric.: 55 (1821) 'non Steph.' (which is said to = perforatum), in DC., Prodr. 1: 551 (1824); Ledeb., Fl. altaic. 3: 368 (1831), Fl. ross. 1: 450 (1842); Spach, Hist. nat. vég., Phan. 5: 389 (1836), in Ann. Sci. Nat. Bot. 5: 357 (1836); Boissier, Fl. orient. 1: 805 (1867); Kerner in Oesterr. Bot. Z. 24: 165 (1874); Krylov, Fl. Altaya 1: 190 (1901); Woronow in Kuzn., Busch \& Fomin, Fl. Cauc. Crit. 3, No. 9: 45 (1906); Hayek, Prodr. Fl. Pen. Balc. 1: 537 (1925); Stefanoff in God. Agr.-les. Fak. Univ. Sofia 10: t. 4 f. 24 (1932), 11: 175 (1933), 12: 87 (1934), in Pflanzenareale 4: karte 7 (1933); Krylov, Fl. Zap. Sib. 8: 1907 (1935); Fedtchenko \& Shishkin, Fl. Yugo-Vost. Evrop. časti SSSR 5: 711 (1938); Stoyanov \& Stefanov, Fl. bulg.: 774 (1948); Gorschkova in Shishkin \& Bobrov, Fl. URSS 15: 243 (1949); E. Wulf, Fl. Kryma 2(3): 109 (1953); Karnaukh in Klokov \& Visjulina, Fl. URSR 7: 307 (1955); Kornás in Szafera \& PawBowski, Fl. Polska 7: 28 (1955); Rzazade in Karjagin et al. (Eds), Fl. Azerbaid_ana 6: 257 (1955); Goşul. \& Nyár. in Săvul., Fl. R. P. Romana 4: 33, t. 3 f. 1 (1956); Janchen in Höfler \& Knoll, Cat. Fl. Austr. 1: 257 (1957); Zelený in Sborník Klubu Prírod. v Brnë 32: 69 (1960); Grossg., Fl. Kavk., 2nd ed. 6: 175, karta 191 (1962); Vasyléva in Pavlov, Fl. Kazakhstana 6: 163 (1963); Robson in Davis, Fl. Turkey 2: 401, f. 12.25 (1967), in Tutin et al. (Eds), Fl. Europaea 2: 269 (1968), in Huxley \& Griffiths (Eds), R.H.S. Dict. Gdng 2: 629 (1992), in Cullen et al. (Eds), Eur. Gard. Fl. 4: 60 (1995); Jordanov \& Kož in Jordanov, Fl. R. P. Bulg. 4: 261, t. 49 f. 1 (1970); Stjep.-Vesel. in Josifović, Fl. Srbje 3: 119, t. 23 ff. 5, 5a (1972); Hegi, Ill. Fl. Mitt.-Eur., 2nd ed. 5(1): 522, ff. 1998 (map), 2007 (1975); Meusel, Vergl. Chor. Zentraleurop. Fl. 2: 288, Karte 285c (1978); Zelený, Jasičová \& Zahradniková in Futák \& Bertová, Fl. Slovenska 3: 311, t. 38 f. 2, map 57 (1982); Hagemann in Flora 173: 109, tt. 9-11, 39 (1983); Dostál, Nová Kvĕtena ČSSR 1: 584 (1989). Type: Russia, 'Habitat in Sibiria', n.d. (fl), Stephan in Herb. Willd. 14473 (B-WILLD-holotype, micro.!).

Fig. 10, Map 17.

H. kohlianum Spreng., Fl. hal. tent. nov.: 214, t. 9 (1806); Baumg., Enum. stirp. Transsilv. 2: 392 (1816); Schur, Enum. pl. Transsilv: 132 (1866). Type: Germany, Halle, 'in vineis ad Bennstadt rarius', July (fl), Sprengel s.n. (JE!-holotype).

H. pulchrum Pallas ex M. Bieb., Fl. taur-cauc. 2: 230 (1808), in synon.

H. hyssopifolium [var.] $\gamma$ sensu Choisy, Prodr. monogr. Hypéric.: 56 (1821). Choisy cited 'Bieb. cauc. 2. p. 231'. 'Type' as for var. pauciglandulosum Choisy (1824).

H. hyssopifolium var. pauciglandulosum Choisy in DC., Prodr. 1: 552 (1824). Type: Ukraine?, Tanais [R. Don], 1819, Goldbach s.n. (G-DC!-holotype).

H. elegans var. pectinatum Čelak. in Oesterr. Bot. Z. 24: 140 (1874). Type: Russia, Ciscaucasus, in pratis ad rivum Kuma prope pagum Maslow, July 1843 (fl), Hohenacker s.n. (W-holotype; K!isotype),

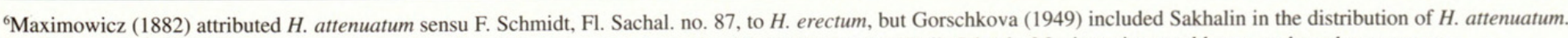
Vorobiev et al. (1974) did not include this species in their key to vascular plants of Sakhalin and the Kurile Islands. Maximowicz would seem to have been correct. 
H. elegans var. stepposum Săvul. \& Rayss, Mat. fl. Basarab. 3: 175 (1934); Guşul. \& Nyár. in Săvul., Fl. R. P. Roman. 4: 34, t. 5 f.1 (1956); Jordanov \& Kož in Jordanov, Fl. R. P. Bulg. 4: 262 (1970). Type: Romania, Reg. Constanța, intra Valea Nucaliler şi Mahmudia (r. Tulcea), Săvulescu ? s.n. (BUCA).

H. elegans var. genuinum Guşul. in Săvul., Fl. R. P. Roman. 4: 34 (roman.), 385 (latin) (1956). Type as for H. elegans Stephan ex Willd.

H. elegans var. elegans Jordanov \& Kož in Jordanov, Fl. R. P. Bulg. 4: 262 (1970).

H. elegans var. pedunculatum Jordanov \& Kož in Jordanov, Fl. R. P. Bulg. 4: 262, 709 (1970) ('pedunculata') in clav., nom. invalid. sine descr. lat. (Art. 36).

Icones: Rchb., Iconogr. bot. pl. crit. 3: 68, t. 280 f. 443 (1825); Icon. fl. germ. helv. 6: t. 350 (1842-1844); Fedchenko \& Shishkin, Fl. Yugo-Vost. Evrop. časti SSSR 3: 712, f. 487 (1938).

Perennial herb $0.18-0.45(0.55) \mathrm{m}$ tall, erect or occasionally shortly ascending and rooting from rootstock, with stems solitary or few, usually branched at most nodes. Stems incompletely 2-lined (nodes terete near base), with \pm dense black punctiform glands on or near lines and occasionally elsewhere; internodes $8-40 \mathrm{~mm}$, shorter than to usually exceeding leaves. Leaves sessile; lamina $15-25(-33) \times 3-$ $9(-12) \mathrm{mm}$, oblong-lanceolate or ovate-lanceolate to triangular-lanceolate, paler beneath, chartaceous; apex subobtuse, margin entire, revolute, base subcordate, subamplexicaul; venation: 3 pairs of main laterals from near base of midrib, tertiary reticulation obscure; laminar glands all pale, dense, or with a few black, scattered, punctiform; intramarginal glands black, rather dense. Inflorescence (1-)5-c. 65-flowered, from 1-4 nodes, with flowering branches from up to 5 nodes below, the whole corymbiform to \pm narrowly pyramidal or narrowly cylindric; pedicels $1-2 \mathrm{~mm}$; bracts and bracteoles 3.5-5 mm long, lanceolate, sparsely black-glandulardenticulate. Flowers (15-)20-25 mm in diam., stellate; buds narrowly ovoid, (sub)acute. Sepals 5, free, 4-6 × 1-2 mm, erect in bud and fruit, lanceolate to ovate-lanceolate, acute, with \pm irregular prominent glands to long-glandular-ciliate; veins 3(5), unbranched; laminar glands pale, linear to distally punctiform; marginal glands black, \pm elongate, sessile or on cilia. Petals golden? yellow, not tinged red in bud, (8-)10-12 × (3-)5-6 mm, 2.4-4 × sepals, oblong-obovate, asymmetric, entire to subentire, laminar glands pale, \pm punctiform, distal, marginal glands black, immersed or rarely \pm prominent, distally dense. Stamens 40-50, ' 3 '-fascicled, longest 7-10 mm, 0.8$0.9 \times$ petals; anther gland black. Ovary 3 -locular, $2-2.5(-3) \times 1-1.5$ $\mathrm{mm}$, cylindric-ovoid; styles 3 , free, 4-6 mm, 1.7-3 $\times$ ovary, widely spreading; stigmas narrowly capitate. Capsule (6)-7-8 $\times 4-5 \mathrm{~mm}, c$. 1.5-2 $\times$ sepals, cylindric-ovoid to conic; valves rather densely longitudinally and obliquely vittate. Seeds yellowish-brown, 0.8-1 $\mathrm{mm}$, cylindric, not carinate; testa finely linear-foveolate. $2 \mathrm{n}=32$ $(\mathrm{n}=16$, Chattaway, 1926).

Well-drained habitats: meadows, stony and scrub steppes and stony slopes on chalk and limestone, Betula and Pinus-Betula woods on sand, shores of rivers and lakes; 0-500 m.

Russia (E. Siberia: Angara-Sayan; W. Siberia: Ob (S.), Upper Tobolsk, Irtysh, Altai; European Russia: Volga-Kama, Transvolga, Lower Don, Ciscaucasia, Daghestan, Volga-Don, Upper Volga), Ukraine (Upper Dnieper [near Kremenets], Middle Dnieper, Upper Dniester, Black Sea, Crimea) [apparently absent from Transcaucasia, despite area records in Gorschkova (1949)]; Germany (Saxony, Rhineland), Czech Republic, Slovakia, Poland, Hungary, Romania, Moldova, Serbia, Bulgaria, Turkey (European) (?)

RUSSIA. Angara-Sayan, Ob, Upper Tobolsk, Irtysh: all fide
Gorschkova (1949). Altai: Chemal distr., Gora Biryutka, 29 June 1927 (fl), Shishkin s.n. (H). Volga-Kama, Transvolga: both fide Gorschkova (1949). Lower Don: Novotscherkassk, 9 June 1911 (fl), Jakuschev s.n. (BM, FR). Ciscaucasia: ad rivum Kuma prope pagum Maslow, July 1843 (fl), Hohenacker s.n. (BM, K); am Terek bei Galjugajer, August (fl \& fr), Herb. Steven s.n. (H). Daghestan: fide Grossgeim (1962: map 191). Volga-Don: Prov. Kursk, prope urbem Koroczka, 1 July 1900 (fl), Schirjewsky 1604 (H). Upper Volga: fide Gorschkova (1949).

UKRAINE. Upper Dnieper: fide Gorschkova (1949). Middle Dnieper: Poltava, n.d (fl), Rogouris s.n. (H). Upper Dniester: Probabin prope Horodenka [Gorodenka], n.d. (fl), Bločky s.n. (BM). Black Sea: Crimea, Simferopol, prope pagum Massanka, 5 July 1900 (fl), Callier 901 (JE, K); Tarkhankutskiy peninsula, balka Onsina near Otlesh, 4 June 1935 (fr), DzensLitovskaya s.n. (LE).

AZERBAIJAN?. E. Transcaucasia, fide Gorschkova (1949), but not Grossgeim (1962: map 191).

GEORGIA?. W. Transcaucasia, fide Gorschkova (1949), but not Grossgeim (1962: map 191).

GERMANY. Upper Saxony: Erfurt, Schwellenburg, 23 July 1852 (fl), Launert s.n. (BM); Erfurt, Mühlhausen, Weinberg, 1951, Meyer s.n. (JE); Halle, Sachsenburg, 1906 (fl), Kappel s.n. (BM); Halle, Rossleben, Bottendorf, 1931, Rothmaler s.n. (JE). Rheinhessen-Pfalz: Alzeyer Hügelland, Wissberg bei Sprendlingen, W-Seite des Gipfelplateaus, 260 m, 9 July 1978 (fl), Kalheber 78-477 (H).

CZECH REPUBLIC. Moravia: Jimoravský Kraj, Hodonin distr., inter pagos Čejč et Čejkovice, c. 220 m, 13 July 1971 (1. fl \& fr), Vicherek 1539 (H); Severomoravský Kraj, Vyškov, prope Větrmky, June 1936 (fl), Weber s.n. (H).

SLOVAKIA. Two records - see Zelený et al. (1982: map 57).

POLAND. Wałbrzych: Dolny Śląska, 35-40 km W. of Nysa (fide Kornaś, 1955: 28).

HUNGARY. Pest: Comit. Pest, in monte Csiki-hagy prope Török-Bábut, 3 June 1926 (fl), Degen s.n. (BM).

ROMANIA. Transylvania [Alba]: Langenthal [Valea Lungă], 18 June 1871 (fl), Barth 515 (BD, BM, H, JE); distr. Alba, inter pagos Ciumbrud et Băgău, c. 300-350 m, 14 June 1930(fl), Nyárády s.n. (H). Moldavia: distr. Iaşi, in foenatis montis 'Ciocălău' prope pagum Rediu-Tatar, c. 150 m, 21 June 1938 (fl), Răvărut in Fl. Rom. Exsicc. 2003a (BD). Wallachia: Dobrogea, RaduNegru (by wellau Constanța o Burarqu), 11 July 1931 (fl), Häyrén s.n. (H).

MOLDOVA. Bessarabia: a Aktherman en Bessarabie, 1822, Tardent s.n. (G-DC).

SERBIA. Vojvodina: fide Stjep.-Vesel. (1972: 120).

BULGARIA. Varna: Baltschik, Schiblak, oberhalb des Strandes, 15 June 1961 (fl), Bisse \& Schneider 166 (JE). Plovdiv: M. Rhodope centr. supra Stanimak [Azenovgrad], 10 June 1892, Wagner in Degen s.n. (JE); Rhodope in collibus ad Alvan Dere, June 1901 (fl), Stríibrný s.n. (BM).

TURKEY. Istanbul: Büyük Han, $c .100$ m, Davidov s.n. See Davis, Fl. Turkey 2: 401 (1967).

7x. Hypericum elegans Stephan ex Willd. $\times$ H. perforatum L.? Raciborski s.n. (June 1904), from Ukraine, Podolia, colles Miodobory, Okno [Okna?] (BM) seems to be this hybrid, which has not hitherto been recorded. It is morphologically intermediate between the two suggested parents.

8. Hypericum tosaense Makino in Bot. Mag. (Tokyo) 17: 79 (1903); H. Léveillé in Bull. Soc. bot. France 53: 502 (1906); Makino \& Nemoto, Fl. Japan: 545 (1925), 2nd ed.: 753 (1931); Y. Kimura in Nakai \& Honda, Nova fl. jap. 10: 221, ff. 73.4, 74 (1951), Enum. Sperm. jap. 3: 184 (1954); Ohwi, Fl. Japan (Engl. transl.): 632 (1965); Horikawa, Atlas of jap. fl. 2: 681 (1976); Momiyama in Satake et al. (Eds), Wild fls Japan 2: 118, t. 114 f. 2 (1982). Type: Japan, Shikōku, Prov. Tosa [Kōchi], Ikku-mura, 27 September 1892 (fl \& fr), T. Makino s.n. (MAK!-holotype).

Map 18; also Kimura (1959: 324, f.1) and Horikawa (see above).

H. tosaense f. tosaense Y. Kimura in Nakai \& Honda, Nova fl. jap. 10: 222 (1951). 


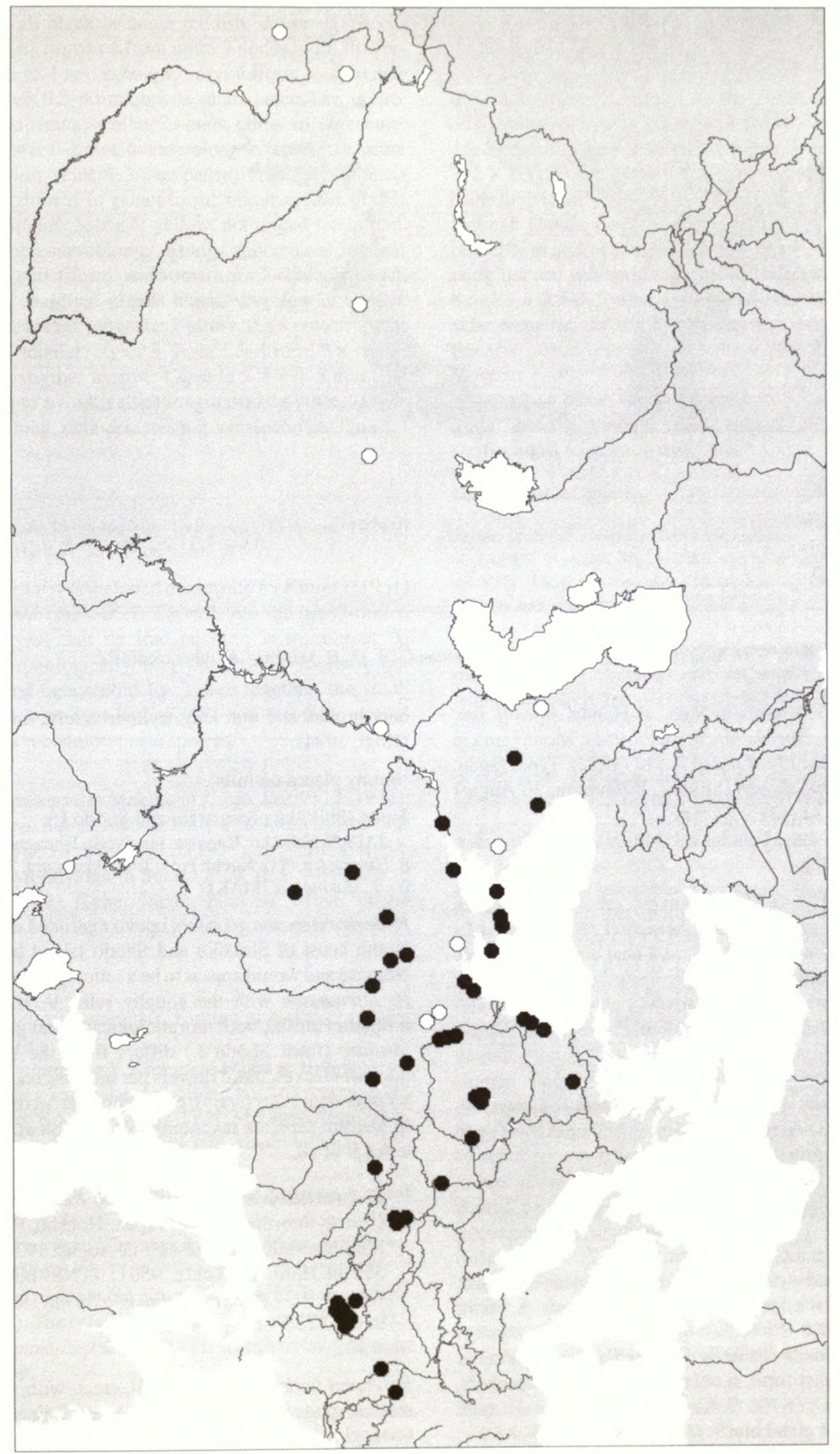

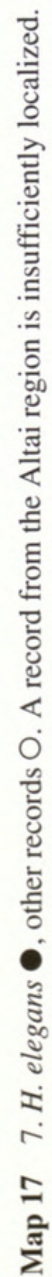




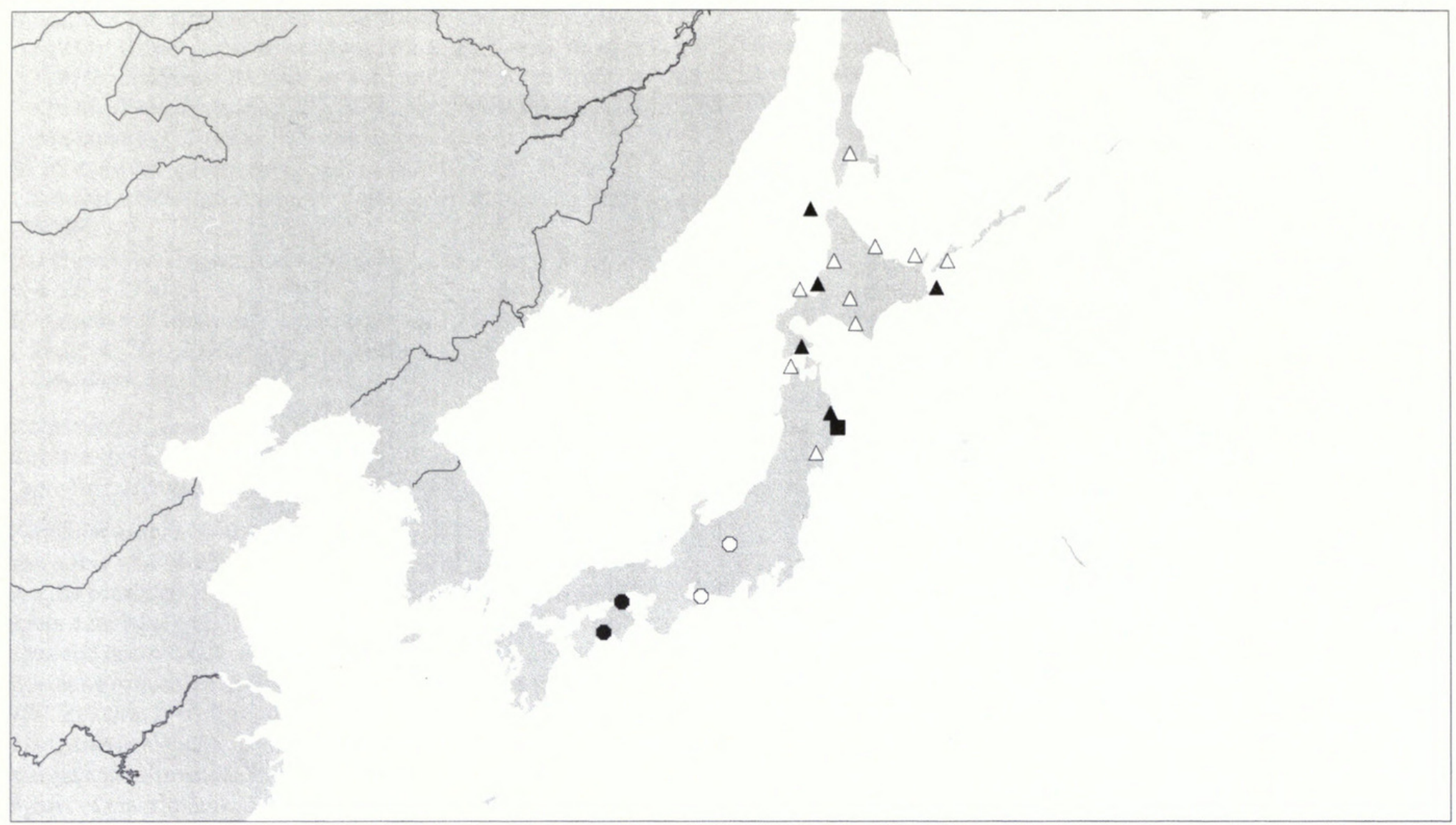

Map 18 a. 8. H. tosaense

b. 9. H. iwatelittorale

c. 10. H. momoseanum $\bigcirc$; d. 11. H. yezö̈nse

other records $\triangle$.

H. tosaense f. insulare Y. Kimura in Nakai \& Honda, Nova fl. jap. 10: 222 (1951), Enum. Sperm. jap. 3: 184 (1954); Momiyama in Satake et al. (Eds), Wild Fls of Japan 2: 118 (1982). Type: Japan, Shikōku, [Kagawa] Ins. Syodo [Shōdo], Ikedamura, 30 August 1910 (fl), R. Hirama s.n. (TI!-holotype).

H. attenuatum pro parte sensu Kitamura \& Murati in Acta Phytotax. Geobot. 20: 197 (1962).

Perennial herb $(0.15-) 0.25-0.57(-0.75) \mathrm{m}$ tall, erect from creeping and rooting base, with stems solitary, branched above. Stems 2lined, with black punctiform glands on and near lines; internodes 10-20 mm, mostly exceeding leaves. Leaves sessile; lamina 5-20 × 2-8 mm, elliptic or ovate-oblong to narrowly oblong or obovateoblong, paler beneath, chartaceous; apex obtuse to rounded, margin entire, base rounded to broadly cuneate; venation: 2(3) pairs of main laterals from lower quarter of midrib; laminar glands pale, punctiform, dense; intramarginal glands black, dense. Inflorescence 3-c. 30 -flowered from up to 3 nodes, with flowering branches from up to 4 nodes below, corymbiform to cylindric and then dense; pedicels $2-$ $3 \mathrm{~mm}$; bracts and bracteoles small, linear-lanceolate to linear, entire. Flowers $15-18 \mathrm{~mm}$ in diam, stellate; buds ellipsoid, obtuse. Sepals 5 , unequal, $2.5-3 \times 1-1.5 \mathrm{~mm}$, triangular-ovate to lanceolate, gradually to abruptly acuminate, entire; veins 5 , outer pair(s) branched; laminar glands pale, punctiform to linear-striiform; intramarginal glands black, punctiform, spaced. Petals 5, bright yellow, veined red in bud, 9-15 × c. 5-8 mm, 3.5-5 × sepals, oblongelliptic, somewhat asymmetric, distally \pm markedly crenate; laminar glands pale, linear to punctiform, scattered; marginal glands black, distally dense. Stamens 60-70, '3'-fascicled, longest 7-11 mm, $0.65-0.8 \times$ petals; anther gland black. Ovary 3-locular, 2.5-4.8 $\times$ c. $1.5 \mathrm{~mm}$, ovoid; styles 3 , free, 3.5-4.5(-5) mm, 1-1.6 $\times$ ovary, spreading-outcurved; stigmas narrow Capsule $7-9 \times 3.5-5 \mathrm{~mm}, c .3$ $\times$ sepals, ovoid-conic to ovoid; valves longitudinally vittate. Seeds dark brown, c. $1 \mathrm{~mm}$ long, cylindric; testa linear-foveolate. $2 \mathrm{n}=16$ (Kogi, 1984).

'Sunny places on hills'.

Japan (Shikōku (Tosa area) and Shōdo I.).

JAPAN. Shikōko: Kagawa: Ins. Syoda, Ikeda-mura, 30 August 1910 (fl), R. Hirama s.n. (TI). Kōchi: Prov. Tosa, Ikku-mura, 27 September 1892 (fl \& fr), T. Makino s.n. (MAK).

Hypericum tosaense occurs in two restricted area of southern Japan (south coast of Shikōku and Shōdo Island between Shikōku and Honshū) and would appear to be a relict species linking the mainland $H$. attenuatum with the equally relict 9 . H. iwatelittorale from northern Honshū, both morphologically and geographically. Forma insulare (from Shōdo I.) differs from the type form in having narrower leaves, more flowers per inflorescence and longer styles ( 2 $\times$ rather than $1.2 \times$ ovary), characters that, in this group, do not seem to warrant separate taxonomic recognition at more than the forma level, if at all.

9. H. iwatelittorale H. Koidz. in J. Pl. Iwateken II, 2: 89 (1937) ('iwate-littorale'). Type: Japan, Honshū, Prov. Rikutiu [Iwate], Shimohei-gun, Todogasaki, 12 August 1934 (fl \& fr), Y. Fukuda 569 in Herb. H. Koidz. 95611 (TNS!-holotype); loc. cit., 12 August 1934 (fl \& fr), Y. Fukuda 569 in Herb. H. Koidz. 9561295613 (TNS!-isotypes).

Map 18.

Perennial herb $0.25-0.32 \mathrm{~m}$ tall, erect, with stems solitary or few and caespitose, branched above. Stems 2 -lined, with black punctiform glands on lines; internodes exceeding to equalling leaves. Leaves sessile (main stem) to $c$. $0.5 \mathrm{~mm}$ petiolate (laterals); lamina (8-)12-14 ×5-8 mm, ovate to elliptic-oblong (main stem) or elliptic to oblanceolate (laterals), paler beneath, chartaceous; apex rounded 
to rounded-obtuse, margin entire, base cuneate to roundedamplexicaul (upper); venation: 3-(4-) pairs of laterals from lower quarter to fifth of midrib; laminar glands pale, punctiform, dense; intramarginal glands all black or some reddish, dense to spaced. Inflorescence (1)3-c. 30-flowered from up to 3 nodes, with flowering branches from up to 4 nodes below, corymbiform to cylindric and then dense; pedicels $0.8-1 \mathrm{~mm}$; bracts small, lanceolate, entire. Flowers 9-10 mm in diam., stellate?; buds ellipsoid, subacute. Sepals 5, subequal, 3-4×1-2 mm, ovate-oblong to lanceolate, acute to subacuminate, entire; veins 5 , outer pair(s) branched; laminar glands pale, linear-striiform to punctiform; intramarginal glands black, few or absent. Petals 5, bright yellow, not tinged red in bud, 6-9 × c. 2-3 mm, obovate-oblong, distally subcrenate; laminar glands pale, linear to punctiform, and sometimes 1-2 black, distal, striiform-punctiform; marginal glands black, very few or absent. Stamens c. 50?, '3'-fascicled, longest c. $7 \mathrm{~mm}$, c. $0.8 \times$ petals; anther gland black. Ovary 3-locular; styles 3, free, 3.5-4 mm, ? $\times$ ovary, spreading-outcurved; stigmas narrow. Capsule 5-8 $\times 4-5 \mathrm{~mm}, c .2$ $\times$ sepals, ovoid-conic to ovoid; valves longitudinally vittate. Seeds dark brown, $1.2 \mathrm{~mm}$ long, cylindric; testa linear-foveolate. $2 \mathrm{n}=$ ?

Coastal.

Japan (Honshū-Iwate).

JAPAN. Honshū. Iwate: Shimohei-gun, Todogasaki, 12 August 1934 (fl \& fr), Y. Fukuda 569 in Herb. H. Koidzumi 95611 (TNS).

Hypericum iwatelittorale was included doubtfully by Kimura (1951) in H. pseudopetiolatum (subsect. 2. Erecta), but the gland-dotted raised stem lines reveal that its true position is in subsect. 1 . Hypericum. It is morphologically very close to $H$. tosaense but considerably distanced geographically. Taken together, the small morphological differences (see key, p. 68) and the wide spatial separation warrant its recognition as a species.

10. Hypericum momoseanum Makino in J. Jap. Bot. 7: 12 (1931); Nemoto, Fl. Japan, Suppl.: 485 (1936); Y. Kimura in Nakai \& Honda, Nova fl. jap. 10: 218, f. 73.3 (1951), in J. Jap. Bot. 34: 323, f.1 (1959); Momiyama in Satake et al. (Eds), Wild Fls of Japan 2: 118 (1982). Type: Japan, Honshū, Prov. Sinano [Nagano], Mt. Hachibuse, 18 July 1930 (fl), Momose s.n. (TI!holotype).

Map 18.

H. momoseanum var. momoseanum Y. Kimura in Nakai \& Honda, Nova fl. jap. 10: 219 (1951).

H. momoseanum var. atumense Y. Kimura in Nakai \& Honda, Nova fl. jap. 10: 219 (1951); in Satake et al. (Eds), Wild fls Japan 2: 118 (1982). Type: Japan, Honshū [Aichi], Prov. Mikawa, Atumi-gun, Fukue, Kantekiyama, 3 August 1939 (fl), Yamamoto s.n. (TI!holotype).

H. tosaense var. atumense (Y. Kimura) Y. Kimura in J. Jap. Bot. 34: 326 (1959).

H. attenuatum pro parte sensu Kitamura \& Murati in Acta Phytotax. Geobot. 20: 197 (1962).

H. yezoënse var. momoseanum (Makino) Ohwi in Fl. Japan (Engl. transl.): 632 (1965). The original (Japanese) edition (Ohwi, 1953: 782) mentions $H$. momoseanum under $H$. yezoënse but makes no formal combination.

Perennial herb $0.25-0.65 \mathrm{~m}$ tall, ascending from woody base, with stems single, unbranched or with short sterile branches throughout. Stems 2-lined, with black punctiform glands on and near lines; internodes 15-30 mm, equalling leaves. Leaves sessile, amplexicaul; lamina $15-30 \times 5-11 \mathrm{~mm}$, oblong to elliptic or oblanceolate, paler beneath, thickly chartaceous; apex rounded-obtuse, margin plane, base rounded; venation: 3-4 pairs of main laterals from base and lower quarter of midrib, tertiary reticulation lax; laminar glands punctiform, pale (minute) and black, submarginal and distal; intramarginal glands black, dense. Inflorescence 7-11-flowered, from 2-3 nodes, with flowering branches from up to 4 nodes below, the whole subcorymbiform to condensed-cylindric; pedicels $0.7-3$ $\mathrm{mm}$ (apical to $5 \mathrm{~mm}$ ); bracts and bracteoles linear, entire. Flowers 15-20 mm in diam., stellate; buds elliptic, obtuse. Sepals 5, subequal, $3-5 \times 0.7-2 \mathrm{~mm}$, oblong-ovate to lanceolate or narrowly elliptic, acute to gradually acuminate, entire; veins 5, occasionally branched; laminar glands pale, linear to striiform, sometimes also a few punctiform and occasionally a few black, distal, punctiform; intramarginal and submarginal glands black, spaced. Petals 5, 'yellow', $8.5-12 \times 2.5-3.5 \mathrm{~mm}, 2.5-3 \times$ sepals, obovate to oblanceolate, subsymmetric, distally not or scarcely crenate; laminar glands pale, linear to punctiform and sometimes a few black, distal, punctiform. Stamens c. 40 , ' 3 '-fascicled, longest $7-8 \mathrm{~mm}, 0.7-0.85 \times$ petals; anther gland black. Ovary 3-locular, c. $3.5 \times 2 \mathrm{~mm}$; styles 3, free, 4 $5 \mathrm{~mm}, 1.2-1.4 \times$ ovary, 'erecto-patent'; stigmas narrowly capitate. Capsule and Seeds not seen. $2 \mathrm{n}=$ ?

Habitat not recorded.

Japan (central Honshū - two localities).

JAPAN. Honshū. Nagano: Mt. Hachibuse, 18 July 1930 (fl), S. Momose s.n. (TI). Aichi: Atsumi-gun, Fukue, Kantekiyama, 3 August 1939 (fl), S. Yamamoto s.n. (TI).

In habit and distribution $H$. momoseanum is intermediate between the southern $H$. tosaense and the northern $H$. yezoënse. Like the former species it has a very restricted distribution, being confined to two stations in central Honshu (Nagano and Aichi Prefectures). Kimura (1959) described var. atumense as having stems unbranched or almost so and larger flowers than var. momoseanum, in which the stems are branched (as in $H$. yezoënse). The differences do not seem to warrant taxonomic recognition.

11. Hypericum yezoënse Maxim. in Bull. Acad. Imp. Sci. SaintPétersbourg 31: 16 (1886), Mél. Biol. Bull. Acad. Imp. Sci. Saint-Pétersbourg 12: 420 (1886); Matsumura, Index pl. jap. II2: 370 (1912); Miyabe \& Miyake, FL. Saghalin: 79 (1915); Y. Kimura in Bot. Mag. (Tokyo) 51: 701, ff. 20-21 (1937), in Nakai \& Honda, Nova fl. jap. 10: 216, f. 73.1 (1951), Enum. Sperm. jap. 3: 186 (1954), in J. Jap. Bot. 34: 323, ff. 1, 2 (1959), in Asahi ... shokobutsu, no. 64: 1508 (1977); Sugawara, Ill. fl. Saghalien 3: t. 600 (1940); Gorschkova in Shishkin \& Bobrov, Fl. URSS 15: 238 (1949); Ohwi, Fl. Japan (Engl. trans.): 632 (1965); Lauener in Notes Roy. Bot. Gard. Edinburgh 27: 5 (1966); Kitamura \& Murati, Clrd Ills Herb. Pls Japan 2: 66 (1972). Type: Japan, Yezo [Hokkaidō, S. Oshima], circa Hakodate, 20 July 1878 (fl), R. Yatabe s.n. (LE-holotype; TI!-isotypes).

Fig. 11, Map 18; also Kimura (1959: 324, f. 1).

H. attenuatum [var.] $\beta$ fruticulosum F. Schmidt in Mém. Imp. Acad. Sci. Saint-Pétersbourg, 7e sér., 12(2): 119 (1868) ['fruticulosa']. Types: Russia, Sachalin, Sachkotau, 18 July 1860 (fl), Friedr. Schmidt s.n. (LE-syntype); loc. cit., late August 1860 (fr), Friedr. Schmidt s.n. (LE-syntype).

H. procumbens R. Keller in Bull. Herb. Boissier 5: 639 (1897); H. Léveillé in Bull. Soc. Bot. France 53: 502 (1906); Matsumura, Index pl. jap. II-2: 370 (1912); Miyabe \& Miyake, Fl. Saghalin: 79 (1915); Makino \& Nemoto, Fl. Japan: 546 (1925); non Desf. ex Willd. (1802) nec Michx. (1803). Type: Japan, Hokkaidō, 'in 


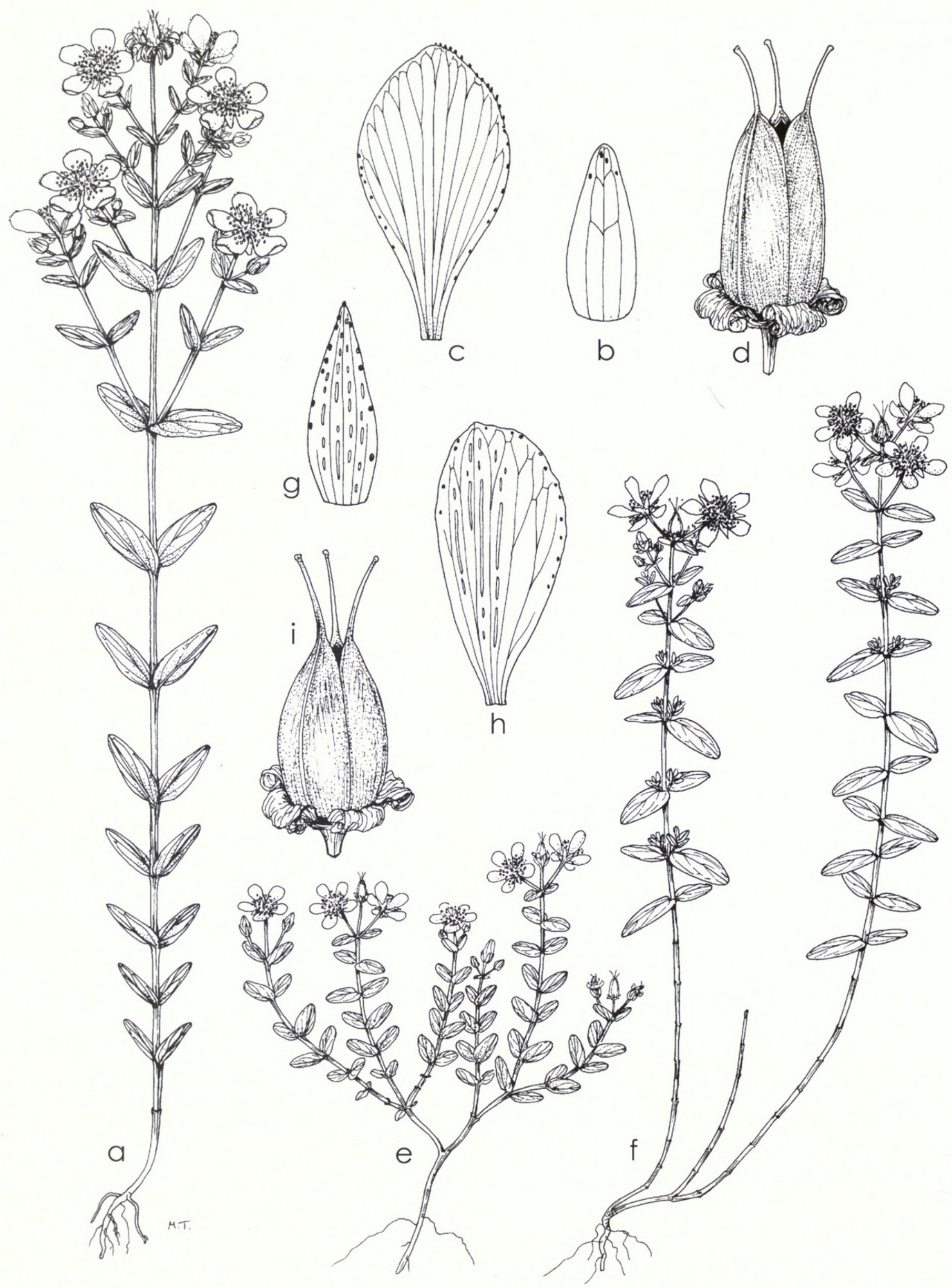

Fig. 11 A. H. scouleri: (a) habit; (b) sepal; (c) petal; (d) capsule. B. H. scouleri 'nortoniae': (e) habit. C. H. yezoënse: (f) habit; (g) sepal; (h) petal; (i) capsule (a, e, f $\times 2 / 3$; c, d, h, i × 4; b, g × 8). A. (a) Copeland 426; (b, c) Kellogg \& Harford 102; (d) Jones 5682. B. (e) Moore \& Steyermark 3711. C. (f, g, h) Furuse 940; (i) Faurie 6905. 
promentorio Gangenzaki', 7 June 1894 (fl), Faurie 13325 (Gholotype?; FI!, K!).

H. mororanense R. Keller in Bull. Herb. Boiss. 5: 640 (1897), in Bot. Jahrb. Syst 33: 553 (1904), op. cit. 44: 49 (1909), op. cit. 58: 194 (1923) in obs. ['morarense']; H. Léveillé in Bull. Soc. Bot. France 53: 502 (1906), op. cit. 54: 595 (1908); Matsumura, Index pl. jap. II-2: 367 (1912); Makino \& Nemoto, Fl. Japan: 543 (1925), 2nd ed. 2: 753 (1931). Type: Japan, Hokkaidō, Iburi, Mororan [Muroran], Faurie 10304 (Z?-lectotype, selected here); Hokkaidō [Shiribeshi], Promontorium Asushi, Faurie 5061 (Z?syntype; K!).

H. oliganthemum R. Keller in Bot. Jahrb. Syst. 33: 553 (1904); H. Léveillé in Bull. Soc. Bot. France 53: 502 (1906) ['iloganthum']; Matsumura, Index pl. jap. II-2: 367 (1912); Makino \& Nemoto, Fl. Japan: 544 (1925), 2nd ed.: 751 (1931). Type: Japan, precise locality not cited, Rein s.n. (B十-holotype).

H. mororanense forma tetragynum H. Léveillé in Bull. Soc. Bot. France 53: 502 (1906); Matsumura, Index pl. jap.: 367 (1912). Type: Japan, Hokkaidō [Soya], in rupibus maritimis Rebunshiri, 1 August 1889, Faurie 3086 (P?-holotype). Kimura (1937: 702) pointed out that flowers with abnormal numbers of parts, such as occur in the type of this variety, are not uncommon in northern or alpine regions of Japan.

H. porphyrandrum H. Léveillé \& Vaniot in Repert. Spec. Nov. Regni Veg. 6: 330 (1909); Matsumura, Index pl. jap. II-2: 368 (1912); Makino \& Nemoto, Fl. Japan: 544 (1925), 2nd ed.: 751 (1931); Gorschkova in Shishkin \& Bobrov, Fl. URSS 15: 257 (1949). Type: Russia: Sakhalin I., in rupibus Tonaichan, 18 September 1908 (fl), Faurie 521 (P?-holotype; KYO!-isotype).

?H. pseudo-nikkoense H. Koidz. in J. Pl. Iwateken 2(2): 87 (1937). Type: Japan, Honshū, Prov. Rikutiu [Iwate], Geibikei, G. Toba in Herb. H. Koidz. 95578 (TSN?-holotype).

?H. yoitiense H. Koidz. in J. Pl. Iwateken 2(2): 101 (1937). Type: Russia, Kurile Is., Kunashir, Yoito, I. Yamamoto in Herb. H. Koidz. 102121 (TNS?-holotype).

Icones: S. Sugawara, Illustr. fl. Saghalien 3: t. 600 (1940); Y. Kimura in J. jap. Bot. 34: 325, f. 2 (1959).

Perennial herb $0.1-0.3(-0.35) \mathrm{m}$ tall or long, erect to ascending or more rarely procumbent from creeping and rooting base, with stems numerous to few and caespitose or rarely solitary, branched or not. Stems 2-lined (if slender almost 4-angled), with black punctiform glands on lines only; internodes (4-)12-28 mm, usually exceeding leaves. Leaves sessile; lamina 8-20(-25) × 3-9 mm, ovate (uppermost) to elliptic-lanceolate or \pm narrowly oblong to oblanceolate, slightly paler beneath, chartaceous; apex obtuse to rounded, margin plane, base broadly cuneate to subamplexicaul; venation: 2-3 pairs of main laterals from lower quarter of midrib; laminar glands pale, punctiform, dense and black, punctiform, few, towards margin, or absent; intramarginal glands black, dense. Inflorescence 3-9-flowered from 1-2 nodes, without or with one pair of flowering branches from node below, corymbiform to subpyramidal; pedicels $0-1 \mathrm{~mm}$ (that of terminal flower to $4 \mathrm{~mm}$ in fruit); bracts reduced-foliar, bracteoles 4-5 mm long, linear-lanceolate, entire. Flowers 15-20 $\mathrm{mm}$ in diam., stellate; buds narrowly ovoid, subacute. Sepals 5 , unequal, 4-6 $\times 1.2-2 \mathrm{~mm}$, erect in bud and fruit, lanceolate to oblong-lanceolate, acute, entire; veins 3-5, unbranched; laminar glands pale, punctiform and sometimes a few black, punctiform, distal; intramarginal glands black, punctiform, rather sparse, distal. Petals 5, pale yellow, not? tinged red in bud, $8-12 \times 3.5-5 \mathrm{~mm}, 2 \times$ sepals, obovate-oblong, asymmetric, subentire; laminar glands pale, linear to punctiform, scattered; marginal and intramarginal glands black, irregular, locally dense. Stamens c. 30-50, '3'-fascicled, longest $c$. $8-10 \mathrm{~mm}$, c. $0.9 \times$ petals; anther gland black. Ovary 3locular, 3-3.2 $\times 1.5-2 \mathrm{~mm}$; styles 3 , free; stigmas narrowly capitate. Capsule 5-8 $\times 3$ ? $-4 \mathrm{~mm}, c .1 .3 \times$ sepals, broadly to narrowly ovoid; valves longitudinally vittate. Seeds dark brown, 1-1.3 mm, cylindric; testa linear-foveolate. $2 \mathrm{n}=$ ?

\section{Habitat not recorded.}

Japan (extreme northern Honshū, Hokkaidō), Russia (southern Sakhalin; Kuriles - Kunashiri and Shikotan Is.).

JAPAN. Honshū. Iwate: Motomura, Akka-mura, Shimohei-gun, 400 m, 13 June 1957 (bud), Shimizu 2052 (K). Aomori, Akita: see Kimura (1959: 324, f. 1). Hokkaidō. Ōshima: Eramachi, 22 July 1890 (l. fl), Miyabe \& Tokubuchi s.n. (K); *Esan Isoya, 26 July 1926, Tatewaki 6110 (SAPS?). Shiribeshi: in Shiribeshi, August 1905 (fl), Faurie 6905 (BM); *Isoya, 18 July 1888, Y. Tokubuchi s.n. (TI?). Ishikari: Hassabu, August 1916 (fl), Kudo in HTU 77274 (TAI); *Mt. Tengu, 15 August 1931, Yamamoto s.n. (SAPS?). Iburi: *Mororan, Faurie 10304 (P?). Hidaka: *Iwayama, Samani, 18 June 1884, K. Miyabe s.n (TI?). Rumoi, Abashiri: see Kimura (1959: 324, f. 1). Soya: Rebun I., Funado-mari-choo, 13 August 1975 (l. fl), Furuse 9407 (K). Nemuro: Hanasaki, prope urbem Nemuro, 7 July 1909 (l. fl), Takeda s.n. (K).

RUSSIA. Sakhalin: *Toyohara [Yuzhno-Sakhalinsk], Takinosawa, 2 August 1928, N. Hiratsuka s.n. (TI?); *Makunkotan circa Motodomari [Tomari?], 15 September 1906, T. Miyake (TI?). Kurile Is.: *Kunasiri, 26-27 July 1935, Y. Takahashi s.n. (TI?); Shikotan, Notoro, 2 August 1931, Ohwi s.n. (KYO?).

Hypericum yezoënse is a reduced 'form' of the central Honshū 10. H. momoseanum, differing from it in habit and inflorescence size. Kimura (1937: 703) notes that the Korean record for this species is erroneous, as is Maximowicz's description of the ovary as onecelled.

12. Hypericum scouleri Hook., Fl. bor-amer. 1: 111 (1831), Pl. Hartweg.: 301 (1848); Torrey \& Gray, Fl. N. Amer. 1: 160 (1838); Torrey in Emory, Rep. U. S. Mex. bound. 2(1): 36 (1858); Greene, Fl. francisc. 1: 112 (1891), Man. bot. San Franc. Bay: 63 (1894); R. Keller in Engl. \& Prantl, Nat. Pflanzenfam., 2nd ed., 21: 179 (1925); Peck, Man. pls Oregon: 481 (1941); Gillett \& Robson in Publs. Bot. Natl. Mus. Nat. Sci. Canada no. 11: 28, t. 12, map 9 (1981); Scott, Alpine Fl. Rocky Mts 1: 458 + f. + map (1996). Type: U.S.A., [Oregon] 'Nw. coast of America, near the Columbia', n.d. [1825] (fl), Scouler s.n. (K!-lectotype, selected here; NY-isolectotype); [Washington?] grassy plains of the Columbia, 1825 (fl), Douglas s.n. (BM!syntype); ex eodem loco, 1826 (fl), Douglas s.n. (BM!-syntype). Fig. 11, Map 19.

H. skouleri sensu Walp., Rep. bot. syst. 1: 387 (1842), sphalm. H. formosum sensu A. Gray, Pl. wright. 2: 17 (1853); Torrey in Emory, Rep. U. S. Mexico bound. 2(1): 36 (1858); Kearney \& Peebles, Arizona fl.: 556 (1951); Clark, Wild fls Pac. Northwest: 312, 322 (1976); Dorn, Man. Vasc. Pls Wyoming (2): 818 (1977), Vasc. Pls Wyoming: 184 (1988); Scoggan, Fl. Canada 3: 1096 (1978); Martin \& Hutchins, Fl. New Mexico (2): 1280 + f., map 758 (1981); Welsh et al., Utah Fl., rev. ed.: 353 (1993); non Kunth (1822).

H. formosum var. scouleri (Hook.) Coult. in Bot. Gaz. 11: 108 (1886); Abrams, Ill. Fl. Pac. States 3: 116, f. 3233 (1951); Munz, Calif. Fl.: 192 (1959); Scoggan, Fl. Canada 3: 1096 (1978).

H. simulans Rose in Contr. U. S. Natl. Herb. 10: 124 (1906); R. Keller in Engl. \& Prantl, Nat. Pflanzenfam. 2nd ed., 21: 179 (1925). Type: Mexico, Hidalgo, Canales Station, 1800 m, 8 August 1904 (fl), Pringle 8993 (US!-holotype; BM!, C!, F!, G!, GH!, K!, MEXU!, NY!, P!, W!-isotypes).

H. collinum var. schmitzii R. Keller in Bull. Herb. Boissier II, 8: 187 
(1908). Type: Mexico, Chihuahua, Potrero passada la Piedat, 1856? (fl), Schmitz s.n. (W!-holotype, F!, US!-photographs).

H. nortoniae M.E. Jones in Bull. Univ. Montana no. 61, Biol. Ser. no. 15: 39, t. 5 (1910) ['Nortonae']. Type: U.S.A., Montana, McDonald Peak, 2190 m, 2 September 1908 (fl), M.E. Jones s.n. (POM!-lectotype, selected here).

H. formosum subsp. scouleri (Hook.) C.L. Hitchc., Vasc. Pls Pac. N.-W. 3: 434 + f. (1961); Taylor \& Macbryde, Vasc. Pls Br. Columbia: 203 (1977); Thorne in Aliso 9: 193 (1978), independent comb.; E. Murray in Kalmia 12: 21 (1982), independent comb.; Moss, Fl. Alberta, 2nd ed. rev. Packer: 404, map 765 (1983).

H. formosum var. nortoniae (M.E. Jones) C.L. Hitchc., Vasc. Pls Pac. N.W. 3: 434 + f. (1961) ['nortonae']; Scoggan, Fl. Canada 3: 1096 (1978).

H. formosum subsp. formosum sensu C.L. Hitchc., Vasc. Pls Pac. N.W. 3: 434 (1961); McVaugh, Fl. Novo-Galicia 3: 51 (2001), pro parte quoad loc. s. w. US; non H. formosum Kunth (1822).

H. formosum var. formosum sensu Dorn, Man. Vasc. Pls Wyoming (2): 818 (1977), Vasc. Pls Wyoming: 184 (1988); Scoggan, Fl. Canada 3: 1096 (1978); non H. formosum Kunth (1822).

H. scouleri subsp. nortoniae (M.E. Jones) J.M. Gillett in Canad. J. Bot. 57: 185 (1979); Gillett \& Robson in Publs. Bot. Natl. Mus. Nat. Sci. Canada no. 11: 30, map 9 (1981). Type as for H. nortoniae M.E. Jones.

H. scouleri subsp. scouleri Gillett \& Robson in Publs. Bot. Natl. Mus. nat. Sci. Can. no. 11: 30 (1981).

Icones: Gillett \& Robson in Publs. Bot. Natl. Mus. Nat. Sci. Canada no. 11: 29, t. 12 (1981); C.L. Hitchc., Vasc. Pls Pac. N.-W. 3: 434 (1961),

Perennial herb $0.05-0.6(-0.8) \mathrm{m}$ tall, erect or ascending from creeping and branching rhizomatous and often stoloniferous base, with stems solitary or up to $c$. 10 , not caespitose, sometimes with short ascending stem branches. Stems shallowly 2-lined or often partially 4-lined (with evident complete or incomplete subsidiary lines) or rarely almost terete, eglandular or sometimes with a few reddish punctiform glands usually on or near lines; internodes 15 $50 \mathrm{~mm}$, usually exceeding leaves. Leaves all sessile or lower subpetiolate, spreading or rarely erect; lamina $12-28(-32) \times 6-15(-$ 18) $\mathrm{mm}$, oblong-elliptic or elliptic to triangular-ovate or suborbicular or (lower) obovate, paler beneath, chartaceous; apex obtuse to rounded, margin plane, base rounded to subcordate or (lower) cuneate; venation: 4-5 pairs of basal and lateral main veins from lower third of midrib; tertiary reticulation rather dense but obscure to lax; laminar glands pale, punctiform, small to large and sometimes 1-2 or more (rarely all) black, distal and submarginal; intramarginal glands black, dense. Inflorescence (1-)8-20-flowered from 1-3(4) nodes, sometimes with flowering branches from 1-2(3) nodes below, the whole narrowly cylindric to pyramidal; pedicels 2-6 mm; bracts and bracteoles 3-6 mm long, ovate-lanceolate to ovate, entire. Flowers $6-15(-25) \mathrm{mm}$ in diam., stellate; buds broadly ellipsoid to subglobose, obtuse to rounded. Sepals 5 , unequal to subequal, $2.5-5.5 \times 1-2 \mathrm{~mm}$, erect in bud and fruit, c. 0.25 united, ovate to lanceolate or narrowly oblong, acute to rounded, entire or sometimes with a few sessile glands or regularly or irregularly shortly glandular-ciliate to -denticulate; veins 5 , distally branched; laminar glands pale, striiform and sometimes black, punctiform to striiform or linear; intramarginal and marginal glands black, irregular or distally regular. Petals 5 , golden yellow, sometimes tinged red in bud, $7-12 \times 3-7 \mathrm{~mm}, \pm$ narrowly obovate, asymmetric, distally subcrenate to entire; laminar glands pale, linear to striiform, occasionally a few black, punctiform to striiform; marginal glands black, distally dense. Stamens c. 50-90(-103), '3'fascicled, longest 6-10 mm, c. 0.7-0.9 × petals; anther gland black. Ovary 3(4)-locular, 3-5 × 2-2.5 mm, ovoid; styles 3, free, (2-)3$6(-8) \mathrm{mm}, c$. 1-1.7 $\times$ ovary, widely spreading; stigmas narrowly capitate. Capsule 6-10 $\times 3.5-6 \mathrm{~mm}$, ovoid to narrowly ovoidpyramidal; valves densely longitudinally vittate. Seeds brown, (0.5-)0.7-0.8 mm, cylindric, not carinate or appendiculate, sometimes? apiculate; testa linear-reticulate. $2 \mathrm{n}=16, \mathrm{n}=8$ (Kyhos, 1967; Ward \& Spellberg, 1983).

Wet meadows, bogs and grassy or rocky banks, stream and lake margins, thickets, coniferous forest, screes; Canada: c. 50-1800 m; U.S.A.: 400-2700 m; Mexico: 1800-3000 m.

Canada (British Columbia (N. to $c$. $55^{\circ}$ ), extreme SW Alberta), western U.S.A. (E. to Montana, Wyoming, Colorado, New Mexico), Mexico (Baja California Norte and Sierra Madre Occidental from Sonora, Chihuahua and Coahuila to Michoacán, México and Vera Cruz [Orizaba]).

CANADA. British Columbia: Kokanee Glacier Park, $1800 \mathrm{~m}, 15$ August 1938 (fl), Moir 276 (K); Selkirk and Rocky Mts, near 51 ${ }^{\circ} 30^{\prime}$ N, Spillamasheen Valley, 1800 m, 30 July 1904 (fl), Heacock 411 (BM, JE, K, Z); Vancouver Island, Cameron Lake, near Port Alberni, 181 m, 5 August 1965, Ashlee 215 (H). Alberta: fide Gillett \& Robson (1981: map 9).

U.S.A. Washington: Douglas Co., near Egbert Spring, 390 m, 2 July 1993 (fl), Sandberg \& Leiberg 361 (BM, K, US*). Oregon: Klamath Co., summit of Cascade Mts, Crescent Lake, 1251 m, 17 August 1934 (fl), Constance 977 (K); Harney Co., Shirk, 1500 m, 19 July 1996 (fl \& e. fr), Leiberg 2598 (BM, US*). Montana: Gallatin Co., Bozeman, Middle Creek, 14 July 1905 (fl), Blankinship 98 (BM, H); Mineral Co., Fish Creek, near mouth of Cache Creek, 1050 m, 11 July 1923 (fl), Hitchcock 1696 (K). Idaho: Latah Co., 6.4 km E. of Farmington, 28 June 1892 (fl), Sandberg, MacDougal \& Heller 512 (BM, K, Z); Shoshone Co., 6.4 km E. of Burke, c. 1620 m, 12 August 1949 (fl), Cronquist 6069 (G). Wyoming: Teton Co., Grand Teton National Park, cirque above Indian Paint Brush Canyon, 2750 m, 220 August 1931 (fl \& fr), Moore \& Steyermark 3711 (BM, W); Park Co., Lewis R., Yellowstone National Park, 9 August 1899 (fl), A. \& E. Nelson 63881 (BM, K). Colorado: Montezuma Co., Mancos, 9 July 1898 (fl), Baker, Earle \& Tracy 889 (BM, K, W); El Paso Co., Colorado Springs, $1650 \mathrm{~m}$, June 1879 (fl), $6.4 \mathrm{~km} \mathrm{NW}$ of Brighton, 2220 m, 4 August 1964 (fl), Bennett 8440 (W). Utah: Pluto Co., Marysvale, Tate Mine, 2700 m, 2 August 1894 (fr), M.E. Jones 5862 (BM); Salt Lake Co., Big Cottonwood Creek canyon, Wasatch Mts, $6.5 \mathrm{~km} \mathrm{NW}$ of Brighton, 2220 m, 4 August 1964 (fl), Bennett 8440 (W). Nevada: White Pine Co., southern Schell Creek Range, E. of Mt Grafton, 2250 m, 11 August 1969 (fl), Holmgren 3869 (W); Douglas? Co., L. Tahoe, 1866 m, 29 July 1931 (fl), L.S. Rose s.n. (JE). California: Butte Co., Jonesville, 1550 m, 18 July 1930 (fl), Copeland 426 (BM, H, K, TAI, W, Z); El Dorado Co., Sierra Nevada Mts, Placerville-Tahoe road, $0.8 \mathrm{~km}$ W. of Lover's Leap, 13 July 1935 (fl), Belshaw 1158 (K); San Bernardino Co., Lythe Creek canyon, 14 July 1902 (fl), Abrams 2727 (K, Z). Arizona: Coconino Co., Bill Williams Mtn, 2100 m, 22 July 1898 (fl), MacDougal 319(G); Cochise Co., Chiricahua Mts, Barfoot Park, 2400-2475 m, 26 September 1906 (fr), Blumer 1426 (K, W, Z). New Mexico: Caltron Co., Gila National Forest, Mogollon, Willow Creek Rec. Area, 2640 m, 26 July 1963 (fl), Demaree 48702 (BM); Santa Fe Co., Santa Fe, Creekbottom, 1847 (fl), Fendler 53 (BM, K, W).

MEXICO. Baja California Norte: Sierra San Pedro Mártir, 2100 m, 21 August 1967 (e. fr), Moran \& Thorne 14453 (CAS, DS). Sonora: San Jose Mts, 8 km S. of Naco, 1800 m, 6 July 1928 (fl), Wolf 2516 (GH). Chihuahua: Sierra Madre near Colonia Garcia, 2250 m, 5 August 1899 (fl), Townsend \& Barber 224 (BM, F, G, GH, K, MEXU, MICH, MO, NY, P). Coahuila: Múzquiz, Hacienda Mariposa, foot of E. slope of Sierra de Puerto Santa Ana, 23 June 1936 (fr), Wynd \& Mueller 245 (K). Durango: Metates, N. of Cueva, 2650-2700 m, 29-30 August 1934 (fl), Pennell 18384 (US). Zacatecas: Sierra Madre, August 1897 (fl), Rosen 2382 (NY, US). Hidalgo: Sierra de Pachuca, 2850 m, 4 August 1898 (fl), Pringle 6941 (BM, C, F, G, GH, K, MEXU, MICH, MO, NY, US, W). México: Lagunas de Zempoala Nat. Park, 3 August 1949 (fl), McAdams 88 (MICH). Distr. Fed.: Desierto de los Leones, 23 September 1938 (fl), Lyonnet 2586 (US). Michoacán: 6.4 km W. 


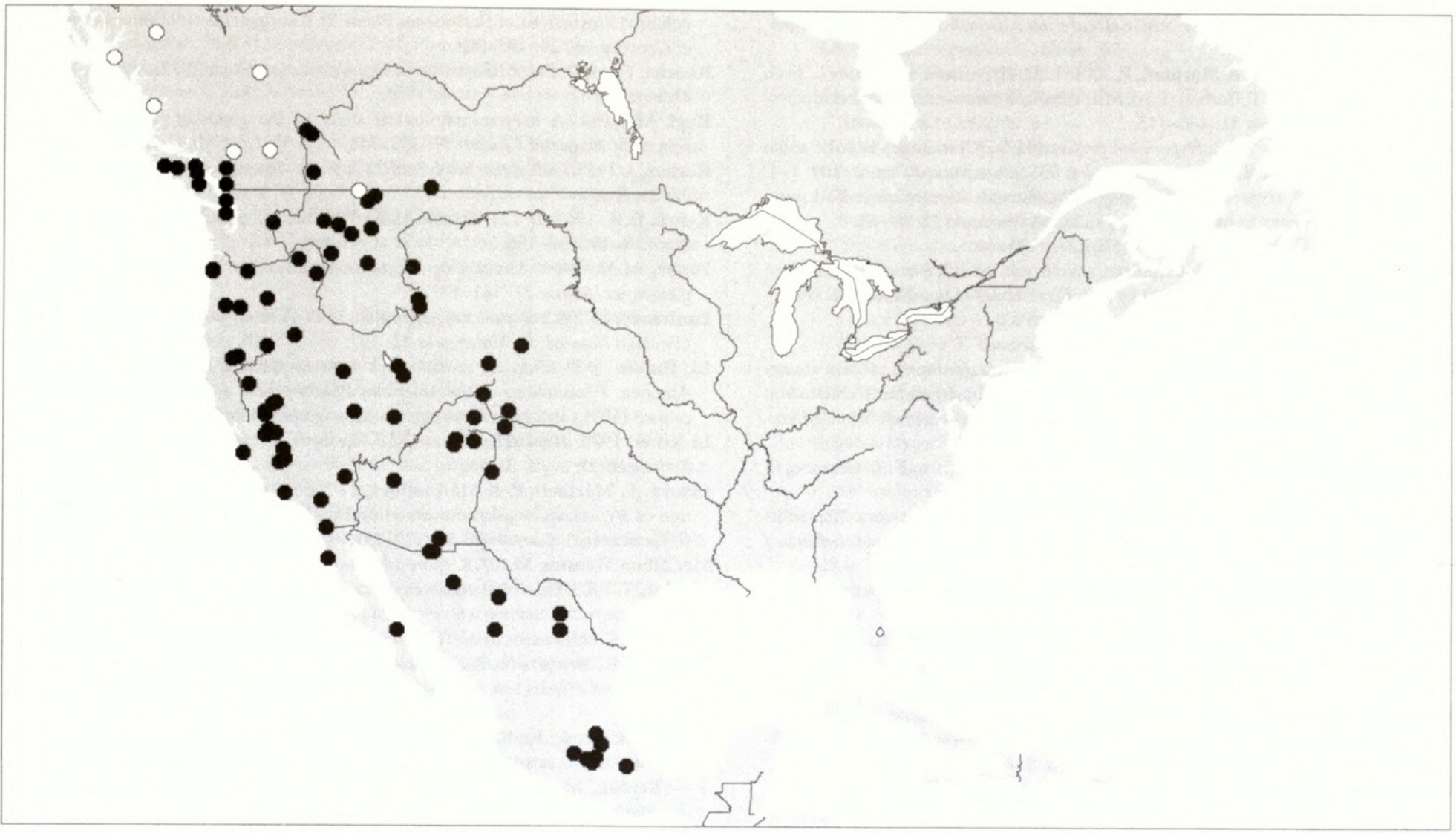

Map 19 12. H. scouleri $\bullet$, other records $\bigcirc$.

of Hidalgo, c. 2000 m, 17 July 1940 (fl), Hitchcock \& Stanford 7194 (F, GH, NY). Vera Cruz: Orizaba, 1846 (fl), Heller 143 (W).

Many authors have included $H$. scouleri in the central Mexican $H$. formosum Kunth as a synonym, subspecies or variety, but the similarities in sepal form and glandularity of these species are due to convergence. Hypericum formosum is related to an undescribed subspecies of the Mexican H. oaxacanum R. Keller (sect. 9b. Graveolentia), whereas the affinities of $H$. scouleri are with the eastern Asian 6. H. attenuatum.

Gillett (1979) and Gillett \& Robson (1981) treated the dwarf, small-flowered alpine form of $H$. scouleri as a distinct subspecies, subsp. nortoniae (M.E. Jones) J.M. Gillett. Further work, however, has revealed a range of intermediate forms between the two 'subspecies' that prevents their recognition. Likewise, the differentiation of a southern U.S. population ('H. formosum subsp. formosum' sensu C.L. Hitchc.) from a northern one ('H. formosum subsp. scouleri (Hook.) C.L.Hitchc.'), based on the 'broader, blunter and less glandular sepals' of the latter, does not appear to be warranted. The glandular, often acute sepals of this New Mexican form are an extreme development in $H$. scouleri, not an indication of affinity with $H$. formosum. In Mexico the sepals become more blackglandular south-eastwards, so that, in the plants known as $H$. simulans, they have black linear laminar glands; but the margin is always entire.

ACKNOWLEDGEMENTS. Once again, as for Part 4(1), I am especially indebted to Dr Peter Raven and Dr Ihsan Al-Shebaz (MO) for help with loans and for hospitality during my studies of Chinese Hypericum in St. Louis, to Yang Chiang (NAS) for label translation and for compiling a database for me, and to Prof. Li Xiwen (KUN) for his publications on Chinese Hypericum. I am also very grateful to Prof. Hideaki Ohba (TI) for facilitating loans of
Japanese specimens. My studies of western Eurasian species have been helped particularly by Dr Pavol Mártonfi (KO), whose work on hybridity in the $H$. perforatum group has thrown considerable light on aspects of this difficult complex; and Prof. Jacques Lambinon (LG), Prof. Fabio Garbari and Dr Daniela Ciccarelli (both PI) have all helped me to clarify the variation in $H$. perforatum itself. As before, I have obtained assistance from many colleagues at the BM, particularly from Mike Gilbert (computing matters, nomenclature and general discussion) and Prof. Chris. Humphries and Josephine Camus (mapping); and Malcolm Beasley and his colleagues in the Botanical Library have, as usual, been very helpful. My thanks are also due to the directors of the following herbaria for loans and/or study facilities: A, ANG, ANK, BASBG, BAV, BC, BD, BISH, BP, BRNM, C, CAS, CL, CLF, DS, E, EVIN, F, FI, FR, G, GH, GL, GRM, GZU, H, HNWP, IBSC, JE, K. KO, KUH, KUN, KYO, L. LANC, LD, LE, LINN, LIV, MAK, MARS, MEXU, MICH, MO, NAS, NY, P, PE, POM, PR, RAW, RNG, S, SEV, SZ, TAI, TI, TNS, TO, U, UBC, UPS, US, W, WAG, WIS, WU, Z. I am again deeply indebted to Margaret Tebbs for the drawings. My wife Eve has,as always, been a help and support in many ways. Finally, I must thank the Keeper of Botany, Prof. Richard Bateman, and his immediate predecessors for study facilities in the Botany Department, and the Stanley Smith Trust for a grant towards illustration costs.

\section{REFERENCES}

Anthony, J. 1976. John Anthony's Flora of Sutherland (Ed. J.B. Kenworthy). Edinburgh.

Ascherson, P. 1864. Flora der Provinz Brandenburg. Berlin.

Axelrod, D.L. 1959. Geological history. In P.A. Munz \& D.D. Keck, A California Flora: 5-9. Berkeley.

Bonnet, E. 1879. Révision des Hypericum de la section Holosepalum Spach. Bulletin de la Societé botanique de la France 25: 274-282.

Čelakovsky, L. 1875. Prodromus der Flora von Böhmen 3. Prague.

Chattaway, M.M. 1926. Notes on the chromosomes of the genus Hypericum, with 
special reference to chromosome size in H. calycinum. British Journal of Experimental Biology 3: 141-143

Ciccarelli, D., Garbari, F. \& Mártonfi, P. 2001. 1232. Hypericum perforatum L. In G Kamari, C. Blanche \& F. Garbari (Eds), Mediterranean chromosome number reports11. Flora Mediterranea 11: 440-443.

\& Robson, N.K.B. 2002. Hypericum perforatum L. (Clusiaceae) in Italy: some taxonomic remarks. Atti della Società toscana di Scienze Naturali ser. B, 109: 1-4

Crackles, F.E. 1990. Hypericum $\times$ desetangsii Lamotte nm. desetangsii in Yorkshire, with special reference to its spread along railways. Watsonia 18: 63-67.

Demiri, M. 1983. Flora ekskursioniste e Shqipërisë. Tiranë.

Dmetrieva, S.A. 1986. Chisla khromosom nekotorych vidov rastenij Berezinskogo Biosfernogo Zapovednika. Zapovedniki Belorussii Issledovanie 10: 24-28.

Duncan, U.K. 1980. Flora of East Ross-shire. Edinburgh.

Franco, J. do A. 1971. Nova Flora de Portugal 1. Lisbon.

Fröhlich, A. 1911. Der Formenkreis der Arten Hypericum perforatum L., H. maculatum Cr. und $H$. acutum Mönch, nebst deren Zwischenformen innerhalb des Gebietes von Europa. Sitzungsberichte der Kaiserlich Akademie der Wissenschaft Wien, Math.Naturwiss. Klasse 120(1): 505-599.

— 1913. Über Hypericum maculatum Cr. × perforatum L. und H. Desetangsii Lamotte. Oesterr. Bot. Z. 63: 13-19.

- 1915. Über zwei der Steiermark eigentumliche Formen aus dem Verwandtschaftkreis des Hypericum maculatum $\mathrm{Cr}$. Mitteilungen der naturwissenschaftlichen Vereines von Steiermark 51: 216-245.

- 1960. Křiženci třezalek (Hypericum) v ČSR [Zwei Hypericum Bastarde in der Tschechoslowakei]. Preslia 32: 97-99.

Gadella, T.W. \& Kliphuis, E. 1966. Chromosome numbers of flowering plants in the Netherlands. Proceedings of the Royal Netherlands Academy of Sciences ser. C, 69 : 541-546.

Gagnieu, A. \& Wilhelm, J.P. 1965. Genre Hypericum [In A. Gagnieu, Les chromosomes dans la cellule, la plante, l'espèce]. In Anon. (Ed.), Travaux biologiques dédit à Prof. Plantefol: 472-473. Paris.

Gamisans, J. \& Jeanmonod, D. 1993. Catalogue des plantes vasculaires de la Corse. In D. Jeanmonod \& H.M. Burdet (Eds), Compléments au Prodrome de la flore corse, Annexe no. 3. Genève.

Gillett, J.M. 1979. New combinations in Hypericum, Triadenum and Gentianopsis. Canadian Journal of Botany 57: 185-186.

— \& Robson, N.K.B. 1981. The St. John's-Worts of Canada (Guttiferae). Canadian National Museum of Natural Sciences, Publications in Botany, No 11. Ottawa

Gorschkova, S.G. 1949. Guttiferae. In B.K. Shishkin \& E.G. Bobrov (Eds), Flora U.R.S.S. 15: 201-258. Moskva.

Greuter, W. 1974. Floristic report on the Cretan area. Memorias de sociedade broteriana 24: $131-171$.

Grossgeim, A.A. 1962. Hypericaceae. Flora Kavkaza, 2nd ed. 6:163-178, karta 181196. Moskva.

Gubanov, I.A. 1996. Konspekt Flora Vneshnei Mongoliy (Sosulistie Rasteniya). Moskva.

Guillén Oterino, A., Laínz, M., Lastra, M. \& Mayor, M. 1997. Sobre Hypericum tetrapterum Fr. e H. undulatum Schousb. ex Willd. en Asturias. Anales del Jardin Botánico de Madrid 55: 161-163.

Gustafsson, Å. 1946. Apomixis in higher plants, I. The mechanism of apomixis. Acta Universitatis Lundensis, N.F. 2, 42(3):1-66.

- 1947. Apomixis in higher plants, II. The causal aspects of apomixis. Acta Universitatis Lundensis, N.F. 2, 43(2): 77-178.

Guşuleac, M. \& Nyárády, E.I. 1956. Hypericaceae. In Să vulescu, T., Flora Republicii Populare Romîne 4: 23-46. Bucuresti.

Hagemann, I. 1983. Wuchsformenuntersuchungen an zentraleuropäischen Hypericum-Arten. Flora 173: 97-142.

- \& Meusel, H. 1984. Hypericum triquetrifolium Turra, ein Wurzelspross-Geophyt, Wuchsform und Verbreitung. Flora 175: 385-405

Halliday, G. 1997. A Flora of Cumbria. Lancaster.

Haslam, S.M., Sell, P.D. \& Wolseley, P.A. 1977. A Flora of the Maltese Islands. Msida.

Hegi, G. 1925. Hypericaceae. Illustrierte Flora von Mittel-Europa 5(1): 498-534 München.

Hoar, C.S. \& Haertl, E.J. 1932. Meiosis in the genus Hypericum. Botanical Gazette 93: $197-205$

Jóhansen, J. 2000. Foroysk flora. Tórshavn.

Jordanov, D. \& Kozhukharov, S. 1970. Guttiferae. In D. Jordanov (Ed.), Flora Reipublicae Popularis Bulgaricae 4: 224-263, 707-709. Sofia.

Karnaukh, E.D. 1955. Guttiferae. In M.B. Klokov \& O.D. Visyulina (Eds), Flora U.R.S.R. 7: 301-313. Kiev.

Kimura, Y. 1937. Conspectus omnium specierum generis Hyperici (excl. sect. Ascyron) in Yezo, Sachalin et Kuriles. I. II. Botanical Magazine (Tokyo) 51: 700-775.

1951. Hypericaceae. In T. Nakai \& M. Honda (Eds), Nova flora japonica 10. Tokyo.

1959. Differentiation of species and superspecies. Journal of Japanese Botany 34: $321-328$

Kitamura, S. \& Murati, G. 1962. New names and new conceptions adopted in our coloured Illustrations of Herbaceous Plants. II. Choripetalae. Acta Phytotaxonomica et Geobotanica 20: 195-208.

Knoche, H. 1922. Flora Balearica; étude phytogéographique sur les Iles Baléares 2. Montpellier

Kogi, M. 1984. A karyomorphological study of the genus Hypericum in Japan. Botanical Magazine (Tokyo) 97: 333-343.

Kornaś, J. 1955. Guttiferae. In W. Szafera \& B. Pawlowskiego (Eds), Flora Polska 7: 22-31. Kraków.

Kyhos, D.W. 1967. In J.H. Thomas (Ed.), Documented plant chromosome numbers. Madroño 19: 134-136.

Laane, M.M. 1969. Meiosis og kromosomstrukturell hybriditet i en del norske plantearter. Blyttia 27: 141-173.

Lanfranco, E. 1982. Hypericum perforatum L. In Greuter, W. \& Raus, T. (Eds), Med Checklist Notulae, 6. Wildenowia 12: 197.

Li, Hui-lin 1952. Floristic relationships between eastern Asia and eastern North America. Transactions of the American Philosophical Society 42: 371-429. [Reprinted (1971) as a Morris Arboretum Monograph. Philadelphia]

Li Xiwen 1990. Hypericum Linn. In Li Xiwen (Ed.), Flora Reipublicae Popularis Sinicae 50(2): 2-72. Beijing.

Lihová, J., Mártonfi, P. \& Mártonfiová, L. 2000. Experimental study on reproduction of Hypericum $\times$ desetangsii nothosubsp. carinthiacum (A. Fröhl.) N. Robson (Hypericaceae). Caryologia 53: 127-132.

McCallum Webster, M. 1978. Flora of Moray, Nairn \& East Inverness. Aberdeen.

Makino, T. 1903. Observations on the flora of Japan. Botanical Magazine (Tokyo) 17 70-98.

1931. Contributions to the flora of Nippon. Journal of Japanese Botany 7: 11-12.

Mártonfi, P., Brutovská, R., Cellarová, E. \& Repčák, M. 1996a. Apomixis and hybridity in Hypericum perforatum. Folia Geobotanica et Phytotaxonomica 31 389-395.

- Michálek, J., Hadinec, J., Mártonfiová, L. \& Repčák. M. 1999. Hypericum dubium - a new species of the Czech flora. Preslia, Praha 71: 337-348.

_ Repčák, M. \& Mihoková, L. 1996b. Hypericum maculatum Crantz subsp. maculatum $\times H$. perforatum $\mathrm{L}$. (Hypericaceae): corroboration of natural hybridization by secondary metabolite analysis. Folia Geobotanica et Phytotaxonomica 31: 245-250.

Maximowicz, C.J. 1882. Diagnoses plantarum novarum asiaticarum. IV. Bulletin de l'Academie Imperiale des Sciences de Saint-Pétersbourg 27: 425-559.

Mennema. J., Quené-Broterenbrood, A.J. \& Plate, C.L. 1980. (Eds), Atlas of the Netherlands flora $\mathbf{1}$. The Hague.

Mulligan, G.A. 1957. Chromosome numbers of Canadian weeds. I. Canadian Journal of Botany 35: 779-786.

Munz, P.A. \& Keck, D.D. 1959. A California Flora. Berkeley.

Nielsen, N. 1924. Chromosome numbers in the genus Hypericum. (A preliminary note) Hereditas 5: 378-382.

Noack, K.L. 1939. Über Hypericum-Kreuzungen. VI. Fortpflanzungsverhältnisse und Bastarde von $H$. perforatum L. Zeitschrift für Induktiv Abstammungs- und Vererbungslehre 76: 569-601.

Papanicolaou, K. 1984. In Å. Löve (Ed.), Chromosome number reports LXXXII Taxon 33: 126-134.

Parvenov, V.I. \& Dmitrieva, S.A. 1987. Kariologicheskaja kharacteristika predatavitelej flory sosudistykh rastenij Berezinskogo Biosfernogo Zapovednika. II Zapovedniki Belorussii Issledovanie 11: 62-69.

Perring, F.H. 1996. A bridge too far - the non-Irish element in the British flora Watsonia 21: 15-51

Pólya, L. 1950. Magyaroszágy növény-fayok kromoszómaszámai. II. Annales biologicae universitatis debrenciensis 1: 46-56.

Pottier-Alapetite, G. 1979. Flore de la Tunisie. 1. Angiosperms-Dicotylédones, Apétales-Dialypétales. Tunis.

Probatova, N.S. \& Sokolovskaya, A.P. 1986. Chromosome numbers of the vascular plants from the Far East (in Russian). Botanicheskii Zhurnal 71: 1572-1575.

Quézel, P. \& Santa, S. 1963. Nouvelle flore de l'Algérie 2. Paris.

Ramos Nuñez, A.F. 1987. Clusiaceae. In B. Valdés, S. Talavera \& E.F. Galiano (Eds), Flora vascular de Andalucía Occidental 1: 314-318.

- 1993. Hypericum. In S. Castroviejo et al. (Eds), Flora Iberica 3: 157-185. Madrid

Raven, P.H. \& Axelrod, D.L. 1978. Origin and relationships of the California flora. University of California Publications in Botany 72: 1-134.

Reynaud, C. 1973. Contribution à l' étude cytotaxinomique du genre Hypericum L. en Turquie, 1. Bulletin de la Société Botanique dela France 120: 201-216.

- 1975. Contribution à l' étude cytotaxinomique de quelques Hypericum mediterranéens. Revue de biologie et d' écologie méditerranéenne 2: 3-8.

Robson, N.K.B. 1956. Studies in the genus Hypericum L. Unpubl. thesis, University of Edinburgh

1957. Plant notes: Hypericum maculatum Crantz. Proceedings of the Botanical Society of the British Isles 2: 237-238.

1958a. Hypericum maculatum in Britain and Europe. Proceedings of the Botanical Society of the British Isles 3: 99-100.

1958b. Hypericum undulatum Schousb. ex Willd. in Ireland? Irish Naturalists 
Journal 12: 269

1968. Guttiferae. In K.H. Rechinger (Ed.), Flora iranica no. 49. Graz.

1972. Reports: Hypericum $\times$ desetangsii. Watsonia 9: 203.

1975. Hypericum L. In C.A. Stace (Ed.), Hybridization and the flora of the British Isles: 164-167. London.

1981. Studies in the genus Hypericum L. (Guttiferae). 2. Characters of the genus. Bulletin of the British Museum (Natural History), Botany 8: 55-226.

— 1998. Hypericum L. In R. Wisskirchen \& H. Haeupler, Standardliste der Farnund Blütenpflanzen Deutschlands: 268-271. Stuttgart.

2001. Studies in the genus Hypericum L. (Guttiferae). 4(1). Sections 7. Roscyna to 9. Hypericum sensu lato (part 1). Bulletin of the Natural History Museum, Botany 31: $37-88$.

Robson, N.K.B. \& Adams, W.P. 1968. Chromosome numbers in Hypericum and related genera. Brittonia 20: 95-106.

_ \& Lambinon, J. 2000. Hypericaceae. In D. Jeanmonod (Ed.), Notes et contributions à la flore de Corse. XVI. Candollea 55: 41-74.

Salisbury, E.J. 1942. The reproductive capacity of plants. London.

Salter, J.H. 1935. The flowering plants of Cardiganshire. Cardiff.

Scannell, M.J.P. \& Synnott, D.M. 1987. Census catalogue of the flora of Ireland. Dublin.

Schlosser, J.C. \& Vukotinovi_, L. 1869. Flora croatica. Zagreb.

Schwarz, O. 1965. Die kritischen Hypericum-Arten der mittel-europäischen Flora Drudea 5: 59-66.

Scoggan, H.J. 1978. Hypericaceae. In The Flora of Canada 3: 1094-1097. Ottawa.

Soldano, A. 1991. Le sottospecie di Cesati; altre novità e precisazioni nomenclatural e tassonomiche su fanerogame d'Italia e dell' area Mediterranea. Atti della Societ Italiana di Scienze Naturali e del Museo Civico di Storia Naturale 131: 245-256.

Stafleu, F.A. \& Cowan, R.S. 1979. Taxonomic literature, 2nd ed. 2. The Hague. 1986. Taxonomic literature, 2nd ed. 6. The Hague.

- \& Mennega, E.A. 1993. Taxonomic literature, 2nd ed., Supplement 2. Königstein

Stenar, H. 1938. Das Endosperm bei Hypericum acutum Moench. Botanisk Notiser 1938: 515-527.

Stjepanović-Veselichić, L. 1972. Hypericaceae. In M. Josifović (Ed.), Flora S. R. Srbije 3: 102-125. Beograd.

Strid, A. \& Franzén, R. 1981. In A. Löve (Ed.), I.O.P.B.chromosome number reports, LXXIII. Taxon 30: 829-842.

Sugiura, T. 1944. Studies on the chromosome numbers in higher plants. VI. Cytologia (Tokyo) 13: 352-359.

Takhtajan, A.A. 1966. Hypericaceae. Flora Armeniy 5: 9-24. Yerevan.

Tourlet, M.E.-H. 1903. Quelques plantes nouvelles d'Indre-et-Loire. Bulletin de la Societé botanique de la France 50: 307-308.

Turland, N.J., Chilton, L. \& Press, J.R. 1993. Flora of the Cretan area. London.

Vilkevičiūté, N. 1971. Hypericaceae. In M. Natkevičait-Ivanauskien (Ed.), Lietuvos TSR Flora 4: 695-703. Vilnius.

Vorobiev, D.P., Woroshilov, V.N., Gurzenkov, N.N., Doronina, J.A., Egorova, E.M., Neczaeva, T.I., Probatova, N.S., Tolmatchev, A.I. \& Czernaeva, A.M. 1974. Key for the vascular plants of Sakhalin and Kurile Islands. Leningrad.

Vul'f, E.V. 1953. Hypericaceae. Flora Kryma 2(3): 106-111, karta 185-1196. Moscow

Wagner, W.L., Herbst, D.R. \& Sohmer, S.L. 1999. Manual of the flowering plants of Hawai' $i$, revised ed. 1. Honolulu.

Ward, D.E. \& Spellenberg, R. 1988. Chromosome numbers of Angiosperms from New Mexico and adjacent areas. Phytologia 64: 390-398.

Wickens, G.E. 1976a. Speculations on long-distance dispersal and the flora of Jebel Marra. Kew Bulletin 31: 105-150.

1976b. The flora of Jebel Marra (Sudan Republic) and its geographical affinities. London.

Winge, Ö. 1925. Contributions to the knowledge of chromosome numbers in plants. $\mathrm{La}$ Cellule 35: 303-324.

Zelený, V., Jasičková, U.M. \& Zahradníková, K. 1982. Hypericales. In J. Futák \& L. Bertová (Eds), Flóra Slovenska 3: 292-313. Veda.

Zhukova, P.G. 1967. Kariologiya nekotor'ikh rasteniy, pereselennykh v PolyarnoAlpȳ̄skȳ̄ Botanicheskȳ̄ Sad. In N.A. Avrorin (Ed.), Pereselnie Rasteniy na Polyarnȳ Sever 2: 130-149. Moskva.

Zohary, M. 1966. Hypericaceae. Flora Palaestina 1: 220-224, tt. 324-329. Jerusalem.

\section{SYSTEMATIC INDEX}

Accepted names are in roman and synonyms in italics; new names and principal references are in bold. An asterisk denotes a figure.

Holosepalum (Spach) Fourr. 73, 81

dubium (Leers) Fourr. $(=1 \mathrm{c}) 73$

quadrangulum (L.) Fourr. (=3) 81

Hypericum L. 61

Sect. Concinna N. Robson 61
Sect. Euhypericum Godr. 67

Subsect. Heterotaenium R. Keller 67

Series Perforata Gorschk. 67

Subsect. Homotaenium R. Keller 67

Series Acuta Gorschk. 67

Series Attenuata Gorschk. 67

Series Crispa Gorschk. 67

Series Elegantia Gorschk. 67

Series Kamtschatica Gorschk. pro parte 67

Series Quadrangula Gorschk. 67

Sect. Graveolentia N. Robson 61

Sect. Homotaenium Y. Kimura 67 Series Bilineata Y. Kimura 67

Series Crispa Y. Kimura 67

Series Quadrangula Y. Kimura 67

Sect. Hypericum 61, 62, 65, 66, 67

Subsect. Erecta N. Robson 61, 62, 66, 115

Subsect. Hypericum 61, 62, 65, 66

Series Hypericum 61-66, 67

Series Senanensia 61, 62, 65, 66, 68

Sect. Roscyna (Spach) R. Keller 61, 62, 63, 65

acutum Moench (=3) 80, 81

subsp. boeticum (Boiss.) Cout. (=2b) 80

subsp. corsicum (Steud.) Rouy (=3b) 84

var. rotundifolium sensu Briq. (=3b) 84

subsp. desetangsii (Lamotte) Rouy (=5xa) 104

var. genuinum (Bonnet) Rouy (=5xa) 104

var. imperforatum (Bonnet) Rouy (=1c) 73

subsp. eu-acutum Hayek (=3a) 81

subsp. tetrapterum (Fr.) Maire (=3a) 81

subsp. undulatum (Schousb. ex Willd.) Rouy (=2) 78

var. anagallidifolium (Boiss.) Post $(=3 \mathrm{c}) 84$

var. anagallidioides (Jaub. \& Spach) Zohary (=3c) 84

var. corsicum (Steud.) Halácsy (=3b) 84

var. insulare (Foucaud \& Mandon) Briquet $(=3 \mathrm{~b}) 84$

var. rotundifolium (Willk.) Schinz (=2b) 80

var. typicum Guşul. (=3) 81

var. undulatum (Schousb. ex Willd.) Pau (=2) 78

forma humile (Boenn.) Hegi (=3) 81

forma patulum (Boenn.) Hegi (=3) 81

acutum $\times$ perforatum $(=5 \mathrm{x}) 108$

aetnaeum Tornab. $(=5 \mathrm{c}) 97$

alatum Retz. $(=3$ ? $) 80$

anagallidifolium Boiss. (= 3c) 84

anagallidioides Jaub. \& Spach $(=3 \mathrm{c}) 84$

ascyron L. 61, 62

subsp. ascyron 62

subsp. gebleri (Ledeb.) N. Robson 62

subsp. pyramidatum (Aiton) N. Robson 62

assurgens Peterm. (=5a) 89, 118

attenuatum Fisch. ex Choisy (6) 62, 63, 65-67, 88, 89, 108, 109*, 111, 114, 119

var. fruticulosum $\mathrm{F}$. Schmidt $(=11) 115$

attenuatum sensu Kitamura \& Murati $(=6+8+10) \quad 114,115$

baeticum sensu auct. plur. (=2b) 78

boeticum Boiss. (=2b) 79, 80

sensu Syme $(=2) 78$

borbasii Formánek (=3) 81

$\times$ carinthiacum A. Fröhl. (=5xb) 105

forma maculatiforme A. Fröhl. (=5xba) 65,106

forma perforatiforme A. Fröhl. (=5xbb) 65, 107

carpaticum Mártonfi $(=5 \mathrm{xbb}) 107$

chrysostictum Webb $(=5 \mathrm{c}) 96$

collinum var. schmitzii $\mathrm{R}$. Keller $(=12) 117$

commutatum Nolte (=1b) 71,76

confertum (Choisy) G. Don (=3) 81

corsicum Steud. (=3b) 84

crispum L. $(=4) 67,84$

decipiens $\mathrm{H}$. Watson $(=2) 78$

deidesheimense Sch. Bip. ex Trev. (?=5a) 89

delphinense Vill. (=1b) 71, 73

$\times$ desetangsii Lamotte (5x) 63, 64, 76, 78, 102, 103*

nothomorph carinthiacum (A. Fröhl.) N. Robson (=5xb) 105

nothomorph desetangsii sensu N. Robson (=5xa) 104

nothomorph perforatiforme (A. Fröhl.) N. Robson (=5xbb) 88, 107

nothosubsp. balcanicum N. Robson (5xc) 64, 103*, 104, 107

nothosubsp. carinthiacum (A. Fröhl.) N. Robson (5xb) 64, 65, 104, 105 nothoforma maculatiforme (A. Fröhl.) N. Robson (5xba) 65, 103*, 106 nothoforma perforatiforme (A. Fröhl.) N. Robson, (5xbb) 65, 103*, 106, 107 
nothosubsp. desetangsii ( $5 x a) 64,103 *, 104$ nothovar. desetangsii sensu N. Robson (=5xa) 104 var. genuinum Bonnet (=5xa) 104 var imperforatum Bonnet (=1c) 73, 74 desetangsii sensu Lloyd $(=2) 78$

$\times$ desetangsii $\times$ tetrapterum $(5 \mathrm{x} \times 3) \quad 108$

$\times$ dubioides Druce $(=5 \mathrm{xx}) 108$

dubium Leers (=1c) $65,68,71,73,74,75$

var. genuinum Syme (=1c) 73

var. maculatum sensu Bab. (=1c) 73

var. perforatum (Tourlet) Pugsley (=1c) 74

dubium sensu Bab. $(=1 \mathrm{c}) 73$

dubium sensu Mauri (=1b) 71

elegans Stephan ex Willd. (7) 62, 63, 65, 109*, 111

var. elegans Jordanov \& Kož. (=7) 112

var. genuinum Guşul. (=7) 112

var. pectinatum Čelak. (=7) 111

var. pedunculatum Jordanov \& Kož. (=7) 112

var. stepposum SÎvul. \& Rayss (=7) 112

elegans $\times$ perforatum $(7 x) 112$

erectum Thunb. 62, 111

erosum (Schinz) O. Schwarz (=5xba) 104

erosum sensu O. Schwarz p. p. excl. typum $(=1$ c) 74,75

fallax Grimm (=1b) 71

subsp. fallax 71

var. fallax 71

forma punctatum $\mathrm{O}$. Schwarz $(=1 \mathrm{~b}) 71$

var. quadrangulare (L.) O. Schwarz (=3) 81

var. quadrangulare sensu O. Schwarz p. p. $(=1 \mathrm{~b}) 71$

subsp. immaculatum (Murb.) O. Schwarz (=1a) 70

foliosissimum Koidz. (=5d) 101

formosum Kunth 119

subsp. formosum sensu C.L. Hitchc. (=12) 118, 119

subsp. scouleri (Hook.) C.L.Hitchc. $(=12)$ 118, 119

var. formosum sensu Dorn (=12) 118

var. nortoniae (M.E. Jones) C.L. Hitchc. $(=12) 118$

var. scouleri (Hook.) Coult. (=12) 117

formosum sensu A. Gray (=12) 117

hyssopifolium Vill.

var. $\gamma$ sensu Choisy (=7) 111

var. pauciglandulosum Choisy (=7) 111

immaculatum (Murb.) Vierh. (=1a) 70

insulare Foucaud \& Mandon (=3b) 84

intermedium Bellynck (=1xb) 76

iwatelittorale H. Koidz. (9) 65, 114, 115

kamtschaticum Ledeb.

var. pibairense Miyabe \& Y. Kimura 65, 66, 68

var. senanense sensu Y.N. Lee $(=6 ?) 110$

kohlianum Spreng. (=7) 111

komarovii Gorschk. (=5b) 89, 95

$\times$ laschii A. Fröhl. (1x) 75, 76, 102

nothoforma froelichii N. Robson (1xb) 76

nothoforma laschii (1xa) 76

leersii C.C. Gmel. $(=1 \mathrm{c}) 73$

lineolatum Jord. (=5a) 89

linnaeanum Callay \& Gren. (=5xa) 104

maculatum Crantz (1) 62, 76, 88, 106, 111

subsp. desetangsiiforme A. Fröhl. (=5xbb) 107

var. aporosum A. Fröhl. (=5xbb) 107

subsp. erosum sensu Schinz \& Keller (=1c) 74

var. imperforatum (Bonnet) A. Fröhl. (=1c) 74

forma latisepalum A. Fröhl. (=1c) 74

[sub]forma lucidum A. Fröhl. (=1c) 74

[sub]forma nigrum A. Fröhl. (=1c) 74

var. perforatum (Tourlet) A. Fröhl. 74

subsp. erosum $\times$ acutum $(=1 \mathrm{xb}) 76$

subsp. erosum $\times$ perforatum $(=5 \mathrm{xa}) 104$

subsp. eu-maculatum Schinz \& Thell. (=1b) 71

subsp. immaculatum (Murb.) A. Fröhl. (1a) 62, 63, 65, 66, 68, 69*, 71, 75,

108

var. epunctatum A. Fröhl. (=1a) 70

var. punctatum A. Fröhl. (=1a) 70

subsp. immaculatum $\times$ attenuatum $(1 \mathrm{a} \times 6) 63$

subsp. immaculatum $\times$ perforatum $(=5 \mathrm{xc}) 108$

subsp. maculatum (1b) 62-65, 68, 69*, 71, 75, 76, 107, 111

forma punctatum (Schinz) Stjep.-Vesel. (=1b) 71

subsp. maculatum $\times$ perforatum $(1 \mathrm{~b} \times 5) 64,102$

subsp. maculatum $\times$ tetrapterum $(1 \mathrm{~b} \times 3) 64,75$ subsp. obtusiusculum (Tourlet) Hayek (1c) 63-65, 68, 69*, 73, 75, 104, 106

var. imperforatum (Bonnet) A. Fröhl. (=1c) 74

var. perforatum (Tourlet) A. Fröhl. (=1c) 74

subsp. obtusiusculum $\times$ perforatum $(=5 \times a) 64,104$

subsp. obtusiusculum $\times$ tetrapterum $(1 \mathrm{c} \times 3) 76$

subsp. quadrangulum (L.) Hayek (=3) 81

subsp. quadrangulum sensu Hayek (=1b) 71

subsp. styriacum A. Fröhl. (=1c) 74

subsp. styriacum $\times$ acutum $(=1 \mathrm{c} \times 3) 76$

subsp. typicum A. Fröhl. (=1b) 71

var. genuinum (Schinz) A. Fröhl. (=1b) 71

var. punctatum (Schinz) A. Fröhl. (=1b) 71

forma luteum A. Fröhl. (=1b) 71

subsp. typicum' acutum $(=1 \mathrm{~b} \times 3) 76$

subsp. typicum $\times$ perforatum $(=1 \mathrm{~b} \times 5) 105$

subsp. undulatum (Schousb. ex Willd.) P. Fourn. (=2) 78

var babingtonii $\mathrm{H}$. \& J. Groves (=1c) 74

var. immaculatum (Murb.) Guşul. \& Nyár. (=1a) 70

maculatum $\times$ acutum $(=1 \times 3) 75$

maculatum $\times$ perforatum $(1 \times 5) 64,76,102,108$

maculatum $\times$ perforatum forma sub-maculatum $(=5 \times \mathrm{xb}) 106$

maculatum $\times$ perforatum forma sub-perforatum $(=5 \mathrm{xbb}) 107$

(maculatum $\times$ perforatum $) \times$ acutum $(=5 \mathrm{xxx}) 108$

maculatum $\times$ tetrapterum (1x) 64,75

marylandicum Biroli ex Colla (=5a) 89

$\times$ medium Peterm. (5xx) 64, 108

microphyllum Jord. $(=5 \mathrm{c}) 96$

$\times$ mixtum Du Moulin (=5xa?) 76, 104

momoseanum Makino (10) 65, 111, 115, 117

var. atumense Y. Kimura (=10) 115

var. momoseanum $(=10) 115$

mororanense R. Keller (=11) 117

forma tetragynum $\mathrm{H}$. Léveillé (=11) 117

nachitschevanicum Grossh. $(=5 \mathrm{c})$ 97, 98

neapolitanum Ten. $(=3) 78,81,82$

var. confertum (Choisy) Guss. (=3) 81

noёanum Boiss. (=5c) 97

nortoniae M.E. Jones (=12) 118

oaxacanum R. Keller 119

obtusum Moench (=1c) 73

officinale Gaterau (=5a) 89

officinarum Crantz (= 5a) 89

oliganthemum R. Keller (=11) 117

ovalifolium Koidz. 62

perforato-acutum $\mathrm{O}$. Kuntze \& Focke $(=5 \mathrm{xx}) 108$

perforato-quadrangulum Lasch $(=5 \mathrm{xa}) 104$

perforatum L. (5) 62-66, 71, 75, 87, 88, 89, 90*, 98 101, 104-107, 110, 111

subsp. angustifolium (DC.) A. Fröhl. (=5c) 96, 97

subsp. chinense N. Robson (5d) 66, 89, 90, 101

subsp. latifolium (Gaudin) A. Fröhl. (=5xbb) 107

forma dentatum A. Fröhl. (=5xbb) 107

forma fimbriatum A. Fröhl. (=5xbb) 107

var. obscurum $\mathrm{O}$. Schwarz (=5xba) 106

subsp. perforatum (5a) 65, 88, 89, 90*, 92, 94, 95, 96, 98

var. pellucidum $\mathrm{O}$. Schwarz $(=5 \mathrm{a}) 91$

subsp. songaricum (Ledeb. ex Rchb.) N. Robson (5b) 65, 66, 89, 90*, 95, 96

subsp. veronense (Schrank) H. Lindb. (5c) 66, 88, 89, 90*, 94, 96, 101

subsp. vulgare (Schimp. \& Spenn.) A. Fröhl. (=5a) 91

forma brevisepalum A. Fröhl. (=5a) 91

forma lineolatum (Jord.) A. Fröhl. (=5a) 91

forma lucidum A. Fröhl. (=5a) 91

var. $\beta$ sensu Choisy $(=5$ a) 89

var. $\gamma$ sensu Choisy $(=5 \mathrm{c}) 96$

var. albiflorum Choisy (=5a?) 89

var. alpinum Parl. (=5a) 89

var. angustifolium Borkh. $(=5 \mathrm{c}$ ?) 96

var. angustifolium DC. (=5c) 88, 89, 96

subvar. lineolatum Rouy $(=5 \mathrm{c}) 97$

var. angustifolium sensu Ohwi (=5d) 101

var. anomalum Frid. (=5a) 89

var. ceretanicum Sennen $(=5 a) 91$

var. collinum Woron. (=5c) 89, 97, 101

var. confertiflorum Debeaux (=6) 101, 110

var. corioides Vokut $(=5 \mathrm{c}) 97$

var. decompositum Nyár. (=5a) 91

var. elatum Choisy $(=5 \mathrm{c}) 96$

var. ellipticum Durand \& Pittier (=5a) 89

var. ellipticum Freyn (=5c) 97 
var. floribundum Sennen (=5c) 97

var. gracile Gruner (=5b) 89,95

var. humile Stranski (=5a) $89,91,93$

var. latifolium Gaudin (=5xbb) 88, 106

subvar. lineolatum Rouy (=5xbb) 107

var. latifolium sensu W. Koch (=5a) 89

var. latiglandulosum Choisy (=5b) 95

var. lineolatum (Jord.) Hayek (=5a) 91

var. longicapsulum Jordanov \& Kož. (=5c) 97

var. mediterraneanum Rouy $(=5 \mathrm{c}) 97$

var. microphyllum DC. (=5c) 96

var. microphyllum H. Léveillé (=5d) 101

var. moesicum Velen. $(=5 \mathrm{c}) 97$

var. nanum Gaudin $(=5 \mathrm{c}) 96$

var. normale Woron. (=5a) 91

var. perforatum, N. Robson (=5a) 91

var. petiolatum Peterm. (=5a) 89

var. platycalyx Čelak. (=5xbb) 107

var. semihumifusum Nyár. (=5a) 91

var. songaricum (Ledeb. ex Rchb.) K. Koch (=5b) 89, 95

var. stenophyllum (Opiz) Wimm. \& Grab. (=5c) 96

var. typicum Beck (=5a) 89

forma microphyllum (DC.) Fiori (=5c) 97

var. veronense (Schrank) Ces. $(=5 \mathrm{c}) 96$

var. vulgare Schimp. \& Spenn. (=5a) 89

forma anomalum (Frid.) Hegi (=5a) 91

forma brevisepalum (A. Fröhl.) Hegi (=5a) 91

forma lineolatum (Jord.) Hegi (=5a) 91

forma lucidum (A. Fröhl.) Hegi (=5a) 91

subvar. lineolatum (Jord.) Rouy (=5a) 89

perforatum $\times$ elegans $(5 \times 7) 64$

perforatum $\times$ maculatum subsp. maculatum $(5 \times 1 b) 105$

perforatum $\times$ maculatum subsp. obtusiusculum $(5 \times 1$ c) 104

(perforatum $\times$ maculatum $) \times$ tetrapterum $(5 x \times 3) \quad 108$

perforatum $\times$ tetrapterum $(5 \times 3) 108$

perforatum group 119

porphyrandrum $\mathrm{H}$. Léveillé \& Vaniot (=11) 117

procumbens $\mathrm{R}$. Keller (=11) 115

przewalskii Maxim. 61

pseudo-nikkoense $\mathrm{H}$. Koidz. (=11?) 117

pseudopetiolatum R. Keller 115

pulchrum Pallas ex M. Bieb. (=7) 111

quadrangulare sensu L. et auct. $(=3) 71,80$

var. alatum (Retz.) Boenn. (=3) 81

var. humile Boenn. (=3) 81

var. patulum Boenn. (=3) 81

quadrangulum L. (=3) 67, 71, 80, 81

subsp. acutum (Moench) Goday \& Carbonell $(=3) 81$

subsp. corsicum (Steud.) Fiori \& Fiori (=3b) 84

subsp. desetangsii (Lamotte) Tourlet (=5xa) 104

subsp. erosum (Schinz) Schinz (=5xba) 106

var. epunctatum Schinz (=1c) 74

subsp. immaculatum (Murb.) Wettst. (=1a) 70

subsp. maculatum (Crantz) Goday \& Carbonell (=1b) 71

subsp. obtusiusculum Tourlet (=1c) 73

var. imperforatum (Bonnet) Tourlet (=1c) 73

var. perforatum Tourlet $(=1 \mathrm{c}) 73$

subsp. quadrangulum sensu Tourlet $(=1 \mathrm{~b}) 71$

subsp. undulatum (Schousb. ex Willd.) Goday \& Carbonell (=2) 78

var. $\beta$ sensu Choisy (=1c) 73

var. $\gamma$ sensu Choisy $(=1 b) 71$

var. $\delta$ sensu Choisy $(=3) 80$

var. acutum (Moench) Fiori (=3) 81

var. ambiguum Schur (=1c?) 73

var. confertum Choisy (=3) 80,81 var. dubium (Leers) Choisy (=1c) 73

var. erosum Schinz (=5xba) 106

var. genuinum Schinz (=1b) 71

var. immaculatum Murb. (=1a) 70

var. macrophyllum Schur (=1b) 71

var. maculatum (Crantz) Choisy (=1b) 71

var. occidentale Franch. (=1c) 73

var. punctatum Schinz (=1b) 71

var. subcorymbosum Schur $(=1 \mathrm{~b}) 71$

var. tetrapterum (Fr.) Borg (=3) 81

forma undulatum (Schousb. ex Willd.) Borg $(=2) 78$

var. undulatum (Schousb. ex Willd.) Choisy (=2) 76

quadrangulum sensu Colm. (=2) 78

quadrangulum sensu Des Étangs $(=1 \mathrm{xb}) 76$

quadrangulum sensu Fr. et auctt.(=1b) 71

quadratum Stokes $(=3) 80$

quadrialatum Wahlenb. (=3) 81

repens Duby ex Nyman $(=3 b) 84$

rotundatum Schur $(=3) 81$

schlosseri Heuffl. $(=5 \mathrm{c}) 96$

scouleri Hook. (12) 62, 65, 66, 111, 116*, 117

subsp. nortoniae (M.E. Jones) J.M. Gillett $(=12) 118$

subsp. scouleri $(=12) 118$

simulans Rose $(=12) 117$

skouleri Walp. $(=12) 117$

songaricum Ledeb. ex Rchb. (=5b) 95

$\times$ sparsiflorum Schur (=5xx) 108

stenophyllum Opiz $(=5 \mathrm{c}) 96$

tenellum Tausch $(=3 \mathrm{~b}) 84$

tetragonum Fr. (=1b) 71

tetraptero-quadrangulum Lasch $(=1 \mathrm{x}) 75$

tetrapterum Fr. (3) $61,64,65,67,71,76,77 *, 78,80,81,98$ subsp. corsicum (Steud.) Zangh. (=3b) 84

subsp. tetrapterum, Zangh. (=3a) 82

subsp. undulatum (Schousb. ex Willd.) P. Silva (=2a) 78

var. anagallidifolium Boiss. (3c) 84

var. boeticum (Boiss.) Cout. (=2b) 78, 79, 80

var. corsicum (Steud.) Boiss. (3b) 84

var. intermedium Coss. \& Germ. (=1xb?) 76

var. neapolitanum (Ten.) N. Terracc. $(=3) 81$

var. rotundifolium Willk. (=2b) 79, 80

var. tenellum (Tausch) Parl. (=3b) 84

var. tetrapterum (3a) $77 *, 80,82$

var. undulatum (Schousb. ex Willd.) Cout. $(=2 a) 78$

forma stigmaphyllum Woron. (=3) 81

tetrapterum group 71

tosaense Makino (8) 62, 65, 111, 112, 114, 115

var. atumense (Y. Kimura) Y. Kimura $(=10)$ 111, 115

forma insulare Y. Kimura (=8) 114

forma tosaense Y. Kimura (=8) 112

triquetrifolium Turra (4) 62, 63, 65, 67, 77*, 84, 87

umbellatum Miel. ex Wohlf. (=1b) 71

undulatum Schousb. ex Willd. (2) $61,64,65,76,78,87$

var. boeticum (Boiss.) Lange (2b) 65, 79, 80

var. undulatum (2a) $65,77 *, 78,80,81$

undulatum $\times$ tetrapterum $(2 \times 3) 80$

veronense Schrank $(=5 \mathrm{c}) 96$

vulgare Bubani (=5a) 91

vulgare Lam. (=5a) 89

yamamotoi group 62

yamamotoi var. riparium Y. Kimura 62

yezoënse Maxim. (11) 65, 115, 116*, 117

var. momoseanum (Makino) Ohwi $(=10) 115$

yezoënse group 62

yoitiense $\mathrm{H}$. Koidz. (=11?) 117 


\section{$2 \mathrm{BHL}$ Biodiversity Heritage Library}

Robinson, Norman K B. 2002. "Studies in the genus Hypericum L. (Guttiferae) 4(2). Section 9. Hypericum sensu lato (part 2): subsection 1. Hypericum series 1. Hypericum." Bulletin of the Natural History Museum. Botany series 32, 61-123. https://doi.org/10.1017/S096804460200004X.

View This Item Online: $\underline{\text { https://www.biodiversitylibrary.org/item/19460 }}$

DOI: https://doi.org/10.1017/S096804460200004X

Permalink: https://www.biodiversitylibrary.org/partpdf/98684

\section{Holding Institution}

Natural History Museum Library, London

\section{Sponsored by}

Natural History Museum Library, London

\section{Copyright \& Reuse}

Copyright Status: In copyright. Digitized with the permission of the rights holder.

Rights Holder: The Trustees of the Natural History Museum, London

License: http://creativecommons.org/licenses/by-nc-sa/4.0/

Rights: http://biodiversitylibrary.org/permissions

This document was created from content at the Biodiversity Heritage Library, the world's largest open access digital library for biodiversity literature and archives. Visit BHL at https://www.biodiversitylibrary.org. 